\title{
Aanteekeningen over het geestelijk leven en de samenleving der Djoeka's
}

(Aukaner Boschnegers)

in Suriname

DOOR

\author{
W. F. VAN LIER
}

MET EEN INLEIDING EN GEGEVENS VAN C. H. DE GOEJE 


\section{N H O U D.}

Inhoud. . . . . . . . . . 131

Inleiding . . . . . . . . . . 133

Literatuur. . . . . . . . . 141

Woordregister . . . . . . 145

Hoofdstuk I. Het volk der

Djoeka's . . . . . . . 155

$\S 1$. Indeeling en bestuur . . . 155

2. Oorsprong van den naam djoeka; taal; schrift . . . 158

3. Karaktereigenschappen . . 159

4. Godsdienstig leven en symbolen

Hoofdstuk II. De mensch . 163

§ 5. De akra... . . . 163

6. Het dubbel . . . . . . 167

7. De kraka . . . . . . 167

8. De jorka . . . . . . 168

9. Ninseki en reïncarnatie . 172

10. De gado (djodjo). . . . 175

11. Gado der tweelingen . . 177

12. Gado (winti) . . . . . 177

13. Kina (treef) . . . . . 177

14. Mekoenoe (koenoe) . . 178

15. Fiofio. . . . . . . . 179

16. Moejèmboe . . . . . . 180

Hoofdstuk III. De goden en geesten . . . . . . . 180

$\S 17$. Nana of Masra Gado (Heere God) . . . . 180

18. Kediampon . . . . . . 181

19. Groangzuella of Grantata 181

20. Gedeosoe . . . . . . . 185

21. Odoen der Bonni's . . . 187

22. Boesimama, Gronmama, Watramama . . . 183

23. De gado's (winti's) . . . 189

24. Bijzonderheden van cenige gado's (winti's) en andere bovenzinnelijke wezens . . 191

25. Kinadci . . . . . . . 196
§ 26. Totemdier . . . . . . 197

27. Hond . . . . . . . . 197

28. Hemel en hemelverschijnselen . . . . . . . . 198

29. Anansi . . . . . . . 198

Hoofdstuk IV. Gemeenschap met het bovenzinnelijke. 198

§ 30. Teekens . . . . . . . 198

31. Droomopenbaring . . . 200

32. Verschijningen. . . . 200

33. Aangeboren bijzondere vermogens . . . . . . . 201

34. Priesters en priesteressen der Oppergoden . . . . 202

35. Tweeling-priesteres . . . 203

36. Priesters der lagere goden. Bezetenheid . . . . 203

37. Idem (vervolg) . . . . 209

38. Kandoe . . . . . . . 218

39. Moela . . . . . . . . 219

40. Eed. . . . . . . . . 220

41. Vervloeken . . . . . 221

42. Lobi doti . . . . . . 222

43. Ogri ai (booze oog) . . 222

44. Soema moffo . . . . . 222

45. Magische invloed van de vrouw. . . . . . 222

46. Magische invloed van Blanken . . . . . . . 224

47. Azeman (vampier) . . . 225

48. Wisi (booze toovenarij) en wisiman . . . . . . 226

49. Bakroe . . . . . . . 228

50. Poeroe wisi . . . . . 228

51. Ago. . . . . . . . . 229

52. Algemeene plechtigheden enz. . . . . . . . 229

53. Dansen . . . . . . . 230

Hoofdstuk V. Heilige voorwerpen enz. . . . . . . 231

$\S 54$. Heilige bundels, beelden, kommen, godenhuisjes . 231 
$\S 55$. Gebeds- en offerplaatsen, Fragatiki, Kréihoso, Kroetoehoso . . . . . . . 234

56. Pimba en grond . . . 236

57. Kruidenbad . . . . . . 237

58. Sangrafoe . . . . . . 240

59. Amuletten en inentingen . 240

60. Water plengen, spijs en drank offeren; tiindriengi. 242

61. Tjifoenga (kifoenga) . . 244

62. Bankje . . . . . 245

63. Trommen, rammelaar, hoorn of fluit, bel; trom- en hoorntaal . . . . . 246

Hoofdstuk VI. Familie en recht . . . . 247

$\S 64$. Matriarchaat, polygamie, bloedschande, overspel . . 247

65. Gezin . . . . . . 248

66. Familie en $l o$. . . . 250

67. Bezit der echtelieden, arbeidsdeeling . . . . . 252

68. Erfrecht . . . . . . . 253

69. Rechtspraak . . . . . 254

70. Straffen . . . . . . 256

Hoofdstuk VII. Het 1 even . 258

§ 71. Vóór de geboorte. . . . 258
§ 72. Geboorte . . . . . . . 259

73. Naam . . . . . . . 260

74. Opnemen in de gemeenschap . . . . . . . . 262

75. Jeugd en volwassenverklaring; kleeding . . . 263

76. Onderwijs . . . . . . 265

77. Relieftatoeage . . . . 266

78. Verloving en huwelijk . . 267

79. Voeding, nijverheid en handel. . . . . . . . 270

80. Ponsoe (visschen met vischvergift) . . . . . 272

81. Ziekte . . . . . . . 273

82. Dood en begrafenis . . . 276

83. Potti na blakka en poeroe

blakka. . . . . . 282

84. Broko déi . . . . . 284

85. Jonggestorven kind . . . 288

86. Albino. . . . . . . 289

87. Verdronkene . . . . . 289

88. Zelfmoord . . . . . . 290

89. Haar en nagels . . . 290

90. Afschuw lijkverbranding . 291

91. Dood en rouwgebruiken bij andere Boschnegers en bij Stadsnegers . . . . 291

Aanvullingen . . . . . . 291 
De heer W. F. van Lier, geboren Surinamer, heeft van 1906 tot 1928 veel omgang gehad met Boschnegers in het Binnenland van Suriname, vooral met die van den stam der Djoeka's (Aukaners), waarbij hij van 1919-25 als posthouder heeft gewoond, tegenover het dorp Pauwi, dat gelegen is iets beneden de Granhollo-vallen aan de Tapanahoni. Ook thans, te Paramaribo wonend, heeft hij nog telkens aanraking met aldaar komende Djoeka's.

Toen ik in 1937 in Suriname kwam, bevond ik den heer van Lier bereid, zijn gegevens, waarvan tot dusver slechts kleine stukjes gedrukt waren, voor publicatie beschikbaar te stellen. Wij hebben gezamenlijk een en ander op schrift gesteld, en dat vindt men in dit opstel. In Nederland heb ik het alles nader geordend en er de vroegere publicaties van van Lier, wat de hoofdzaken betreft, mede in verwerkt en voorts uittreksels uit mijn reisdagboeken van 1903, 1904, 1907 en 1937 toegevoegd en enkele malen iets aangehaald uit werken van anderen, of naar die werken verwezen.

Voor zoover niet anders is vermeld, heeft het alles betrekking op Djoeka's, doch hier en daar wordt ook gesproken over Bonni's, Paramakkaners of nog andere Boschnegerstammen en over Stadsnegers, waarmede hier bedoeld zijn die surinaamsche Negers (waaronder velen van gemengd bloed), welke niet tot een Boschnegerstam behooren. Al die groepen staan n.1. volkenkundig zeer dicht bij elkaar. Wie een dier groepen bestudeert, vindt er baat bij, tevens te kijken hoe het bij de andere is. Daarom leek het mij doelmatig, de inlichtingen die ik in $1937 \mathrm{kreeg}$ van een Christen-Saramakkaner en van eenige Stadsnegers, aan dit opstel toe te voegen (gemerkt SAR en STAD), en ten gerieve der gebruikers heb ik dikwijls nog verwezen naar de uitvoeriger mededeelingen van anderen.

$\mathrm{Bij}$ het gebruik der vele in de Literatuurlijst vermelde bronnen, zij eenige voorzichtigheid aanbevolen; niet allen die over die onderwerpen wat hebben medegedeeld, hadden genoeg tijd of een bijzonder talent; slechts enkelen waren vrij van vooroordeel; en het komt nogal eens voor dat iets klakkeloos is overgenomen van een voorganger, zonder dat dit erbij is vermeld. Het hoogste schat ik het werk van Coster, de Penards, van Lier, Junker en de Herskovitsen. 
Hoewel dit opstel slechts ten doel heeft, gegevens beschikbaar te stellen, kon het niet anders, of er vestigde zich bij mij, onder het uitwerken, een meening over verschillende vraagstukken. Misschien heeft men er iets aan, als ik die, zeer in het kort, hier laat volgen, waarbij ik de surinaamsche Negers tot één groep samenvat en, zonder telkens de bron te vermelden, gegevens van allerlei onderzoekers gebruik.

1. Bij omgang met surinaamsche Negers kan men opmerken, hoe het voor deze menschen vanzelfsprekend is, dat deze wereld beheerscht wordt door bovenzinnelijke machten, en dat de mensch, althans de Neger, verstandig doet, daar terdege rekening mee te houden. De Stadsnegers zijn vrijwel allen aangesloten bij een christelijk kerkgenootschap en veelal hebben zij europeesch schoolonderwijs genoten; doch velen zijn nog allerminst los van de oude magische praktijken. Van de Boschnegers zijn slechts kleine groepjes gekerstend; de overigen leven geheel in hun magische negerreligie.

Uit twee bronnen kunnen zulke geloofsopvattingen gevoed worden: uit waarneming, en uit interpretatie van waarnemingen, onderstelling en fantasie. Bij de surinaamsche Negers wordt echter alles ingepast in de overgeleverde leer, waar men hardnekkig aan vasthoudt en die waarschijnlijk oeroud is, want het meeste ervan is ook in Afrika aangetroffen.

2. Men komt het gemakkelijkst tot een inzicht in die zaken (voor zoover dat den verstandsmensch mogelijk is), door te beginnen bij het verschijnsel der bezetenheid. Want hier hebben we te doen met een goed geconstateerde werkelijkheid, die tegelijk een grondslag is van de magisch-religieuse opvatttingen van deze menschen.

Deze bezetenheid is een gewoon verschijnsel bij de Negers in Afrika ${ }^{1}$ ) en in verschillende deelen van Amerika ${ }^{2}$ ), ook in Suriname, waar dikwijls Europeanen er getuige van waren, ook ik.

1) Een overzicht geeft A. Friedrich, Afrikanische Priestertümer, Stuttgart 1939. - In dit opstel zal slechts bị uitzondering naar Afrika verwezen worden; de aan te halen werken zijn: R. E. Dennett, At the back of the black man's mind, London 1906; A. B. Ellis, The Tshi-speaking peoples of the Gold Coast, The Ewe-speaking peoples of the Gold Coast, The Yoruba-speaking peoples of the Slave Coast, London 1887. 1890, 1894; G. Härtter, Sitten der Angloer, Berlin 1906, Z. f. Ethn.; M. J. Herskovits, Dahomey, New York 1938; E. Peschuël-Loesche, Volkskunde von Loango, Stuttgart 1907; D. Westermann, Die Kpelle, Göttingen 1921.

2) Cuba: F. Ortiz, Los negros brujos, Madrid 1906 (niet geraadpleegd); Haiti : E. C. Parsons, Spirit cult in Hayti, J. Soc. Amér, Paris XX 1928, M. J. 
De surinaamsche Neger heeft, als de bezetenheid intreedt, de gewaarwording van ,een gloed die spiraalsgewijze door zijn brein golft, waarna wilsverlamming volgt. Door het geheele lichaam trilt een warme gloed, en het geloof wil, dat men zich onder die omstandigheden op allerlei wijzen kan verminken, zonder dat er bloed vloeit. Ook pijn wordt niet gevoeld, wijl de connectie van het lichamelijk gevoel met de ziel tijdelijk verbroken is. Bij den begeesterde ontstaat een dubbele natuur of liever persoonlijkheid. Hij is bij zijn volle verstand, maar een ander ik is in hem gevaren, dat zijn eigen ik (wil) overheerscht. Een nevel schijnt van zijn brein afgenomen; hij herinnert zich toestanden en omstandigheden, waarin hij op deze aarde nooit verkeerd heeft, m.a.w. hij denkt en handelt door den geest van een ander, die zijn wil aan banden legt. In dezen toestand weet hij heilzame kruiden aan te wijzen, welke hij in nuchteren staat niet kent, allerlei raad te geven, m.a.w. zijn kennis is verdubbeld, ja zelfs vertienvoudigd, even als zijn lichaamskracht”. Enz. (1P 178-179) ${ }^{1}$ ).

Een Djoeka-vrouw zeide mij : ,als de gadoe (god) in mij is, dan draait het voor mijn oogen".

De omstanders zien, dat de betrokkene begint te beven; de blik verstart en als hij of zij spreekt, dan klinkt de stem anders dan gewoonlijk. Als het gewone bewustzijn is wedergekeerd, dan weet de betrokkene zich niets meer te herinneren van wat hij tijdens de bezetenheid heeft gedaan.

De verklaring die de Negers geven, komt hierop neer, dat bij het gewone bewustzijn de mensch zelf, ondersteund door zijn akra, handelt en spreekt; tijdens de bezetenheid is het een der winti's van dien mensch, die handelt en spreekt. De akra is een bovenzinnelijke macht die behoort bij het hoofd of de handen en het vegetatieve leven van het lichaam, en die ook den draad der herinnering, de rede, onderhoudt; als de akra verstoord is, of is ontsnapt of ontvoerd, dan wordt zijn drager lusteloos of verward en sterft dikwijls. Als een wint $i$ vertoornd is, dan toont zich ziekte in het lichaamsdeel of orgaan dat aan die bepaalde wint $i$ is toegedeeld $(2 \mathrm{H} 74,85)$. Een winti kan

Herskovits, Life in a Haitian Valley, New York \& London 1937; Brazilië: A. Ramos, O Negro Brasileiro, Rio de Janeiro 1934, N. Rodrigues, O Animismo fetichista dos Negros Bahianos, Rio de Janeiro 1935; E. Ignace, Le fétichisme des nègres du Brésil, Anthropos III, 1908. Een algemeen werk over bezetenheid is T. K. Oesterreich, Die Besessenheit, Langensalza 1921.

1) Zie voor deze afkortingen de lijst van literatuur, 
den mensch slechts bezitten, als de akra toestemming verleent, en dan treedt de winti in het hoofd.

Als men alles leest wat van de winti verteld wordt, dan wordt het waarschijnlijk dat een winti een menschelijke drift, instinct of ander in het onderbewustzijn (voorbewust, onbewust) aanwezig krachtcomplex is, van zoodanige macht, dat het nu en dan het ik-wezen van den betrokkene overweldigt.

De Neger identificeert de winti's met in de natuur werkende krachten en hij neemt aan, dat een winti van een natuurobjekt in een mensch kan overgaan, en omgekeerd.

Alles wat materie is, heeft volgens den surinaamschen Neger tegelijk ook geest. En met het innerlijk der natuur staat het onderbewustzijn van den mensch blijkbaar in rechtstreeksche gemeenschap. Ik haal hier nog aan 3J 85 ,De geesten van sommige dieren worden geacht door de levenswijze van het betrokken dier kennis te hebben gekregen van de geneeskrachtige middelen als kruiden, boomschors enz. Door deze geesten bezeten menschen oefenen daarom de geneeskunde uit”. En $2 \mathrm{H} 57$,An informant told of one such remedy that had restored his own health, which consisted of herbs gathered by his mother in the bush, while her moves to pluck now one, now another, were directed by the winti of the diviner who, in his own home in the city, sat in a state of possession, shaking a rattle and chanting".

De Negers gelooven, dat de winti's hoogere machten zijn; de Djoeka's noemen ze gadoe (god), de Negers van Bahia, santo (heilige). M.i. behoeft men niet te twijfelen aan de mogelijkheid, dat de bezetene soms door belangrijke instincten geleid wordt. Een andere zaak is, of dat dikwijls voorkomt en of niet de Neger klakkeloos allerlei wat tijdens het leven in het onderbewuste of onbewuste is gekomen, voor hoogere openbaringen houdt. Ten deze zou men de bezetenheid kunnen vergelijken met den droom.

Min of meer hetzelfde als de winti's der Negers, lijken mij de geesten die den Indiaan in de extase verschijnen en van wier krachten de medicijnman zich bedient. Daar is men al niet ver meer af van de ideeën van Plato, en vervolgens van wat wij, als wij denken, als „begrippen” gewaarworden.

3. Het blijkt voorts, dat voor de winti's, en ook voor de nog hoogere machten, onze opvattingen omtrent plaats, getal en tijd, niet gelden. Ook staan de materieele en de moreele zijde van het leven hier veel dichter bij elkaar, dan naar onze opvatting: de akra of een 
winti van een mensch kan eischen stellen aan diens kleeding of sieraden, doch evenzeer aan zijn moreel gedrag. En er is een gelijkstelling tusschen lichaam en buitenwereld: is de akra of een winti verstoord, dan wordt diens drager ziek, of er treft hem (van buiten) tegenspoed. De ongescheidenheid van geest of ziel en natuur, van het moreele en het materieele, kan men ook opmerken in het gebruik van woorden: wisi is zoowel vergift, als magisch kwaad en ook kwade gezindheid jegens iemand; obia is zoowel magisch helpende kracht, als medicijn; pori bezigt men om an te duiden dat iets materieels bederft of onbruikbaar wordt, dat een god of magische kracht verdwijnt of krachteloos wordt, en om moreel verderf aan te duiden.

En men neemt aan dat er een natuurlijk innerlijk verband is tusschen de individuen: als een Neger bepaalde verkeerde dingen doet, dan kan er een koenoe, een vloek, over zijn geheele familie komen, tot in het nageslacht. - Het zal wel zoo zijn, dat de overgroote meerderheid der-surinaamsche Negers hier eenvoudig de overgeleverde leer aanneemt, en als er in zoo'n familie eeı sterfgeval of ramp voorvalt, zulks domweg aan den vloek toeschrijft; misschien is er zelfs niemand die een echt inzicht heeft. Doch er blijkt hieruit, dat men een werkelijk verband aanneemt tusschen de leden van een familie (of van een onderstam of van den geheelen stam) onderling en met de goddelijke machten.

4. Bij de akra is het verband met het menschelijke lichaam van nature gegeven. Zoo'n akra behoort bij het individu en het eenige verband met de natuur is, dat de akra een zekeren hang heeft naar den geboortegrond, of de plaats waar men lang woonde. Maar er zijn slechts 7 soorten van akra's (eigenlijk 7 mannelijke en 7 vrouwelijke), elk behoorende bij een naam en deze bij een dag der week en op dien dag der week wordt de betrokkene geboren. Wijl dit uit Afrika is overgekomen, mag men hier wel denken aan de 7 planeetsferen der oudheid.

$\mathrm{B}$ ij de winti's is er het dubbele verband met het menschelijk lichaam en met iets in de buitenmenschelijke natuur.

5. De jorka, de doodengeest, heeft aan het lijk nog altijd een soort verblijfplaats. De Boschnegers laten het lijk, of haar en nagels, door twee mannen op het hoofd dragen; men stelt nu vragen aan het lijk of aan de jorka, en deze antwoord door de bewegingen der dragers, die tijdelijk haar willoos werktuig zijn. Op geheel dezelfde wijze stelt men vragen aan den heiligen bundel van een godheid. Het is 
mogelijk, dat in zoo'n bundel zich altijd iets bevindt van het lichaam van iemand die een bijzondere verbinding had met die godheid, of iets dat door zoo'n persoon gedragen of gebruikt is.

6. Doch ook het woord is drager van den geest. De wintiman kan een beeld of poppetje maken, of een armband of dgl. van een bepaalde samenstelling. Hij brengt zich nu in een toestand van geestvervuldheid en spreekt tegen het voorwerp, waardoor de geest zich ook daaraan hecht of erin treedt. Zulke heilige bundels, afgodsbeelden, amuletten enz. van deze Negers, kunnen wij m.i. opvatten als een stoffelijke plek waar men een geest kan bereiken, of waar men den geest bij zich heeft om goede invloeden aan te trekken of kwade af te weren.

Bij het natuurobjekt of het vervaardigde voorwerp waarin een geest aanwezig is, offert men aan dien geest. De opvatting is, dat de geest het bovenzinnelijke van het stoffelijk offer geniet. Een soortgelijke opvatting wordt gemeld uit Afrika: „With regard to solid food, they believe that the gods make use of the spiritual part of it, leaving the material portion behind; for there is a general belief that nost, if not all thingo, pooseos two individualities, a tangible and an intangible." (Ellis, Tshi 73-74).

7. Merkwaardigerwijze zijn wij wel betrekkelijk goed ingelicht over de akra, de winti's enz., die in den mensch werken, doch blijkt niet, wat datgene is, waarin die beginselen werken. Wat ik hier laat volgen is slechts een proeve van verklaring.

Waarschijnlijk vat de Neger zichzelf in de eerste plaats als aardsch schepsel, de Boschneger als geheel verbonden met zijn bere (familie), lo (onderstam) en stam (waarbij echter in het oog te houden, dat het aardsche voor deze menschen bestuurd wordt door, of doordrongen is van iets halfgeestelijks). De winti's gaan dikwijls over in een familielid; de koenoe (vloek § 14) is erfelijk; van den vader erft men de boasi-kina (treef $\S 13$ ); een mensch erft ook iets van iemand die vroeger geleefd heeft (ninseki $\S 9$ ), of wel er is een eeuwige kern die zich telkens opnieuw incarneert.

Aan het zich in den moederschoot vormend menschenwezen werkt ook de djodjo (natuurbeschermgeest $\S 10$ ), misschien de plaatselijke gronmama ( $\S 56,22$ ), of nog meer. Vanuit een andere, wellicht hoogere, geestelijker, sfeer, komt de akra (levensgeest, § 5). Gedurende het leven maakt de mensch van allerlei door en in de meesten werken winti's, in sommigen jorka's (geesten van overledenen), en uit hetgeen de mensch bij de geboorte meebracht en wat 
er verder gebeurde, vormt zich zijn persoonlijkheid, en dit is een reëel krachtencomplex, dat na den dood blijft als jorka (doodengeest, $\S 8)^{1}$ ).

Slechte jorka's tracht men den terugkeer te beletten door het lichaam weg te werpen enz.; wellicht hield de straf van levend verbranden ook daarmede verband. Gewone jorka's tracht men tot rust te brengen, door rouw, offers en feesten. De Granjorka's worden middelaars tusschen menschen en goden.

Paramaribo-Den Haag 1937-39.

C. H. DE GoeJE.

1) Men zou (1) akra en (2) jorka kunnen vergelijken met de twee elementen der ziel volgens de Guarani-Indianen (C. Nimuendajú-Unkel, Religion der Apapocúva-Guaraní, Z. f. Ethn. Berlin 1914): (1) de ayvucué, die uit de hemelen komt, er bij de geboorte reeds is en na den dood weder naar de hemelen gaat en zich opnieuw kan incarneeren; aan dit zieledeel is de rust eigen en de goede en zachte neigingen en de lust naar plantaardig voedsel: (2) de acyiguá die zich iets later bij het kind begint te toonen en na den dood als gevaarlijke geest kan blijven rondwaren; aan dit zieledeel is de onrust eigen en de gewelddadige en kwade neigingen en de lust naar dierlijk voedsel. Iets van dergelijken aard is wellicht de onderscheiding bij de Kalienja's (en andere Indianen van Guyana) tusschen yakuwa's (lichtgeesten) en yoloka's (geesten der duisternis). Parallel hieraan, bij Indianen zoowel als bij Negers, de onderscheiding tusschen goede medicijnmannen en booze toovenaars. - Er is geen sprake van, dat de Negers van Suriname dergelijke dingen van de Indianen zouden hebben geleerd, of omgekeerd. 


\section{I T ERAT UUR.}

afkorting

- L. A. Bakbuis, Verslag der Coppename-expeditie, T. K. N. Aardr. Gen. 1902, overdruk.

- H. D. Benjamins, Treef en lepra in Suriname, De W. I. Gids XI 1929.

- id., Sneki-koti, id., 1929, 1932 (pp. 3, 317).

- P. J. Benoit, Voyage à Surinam, Bruxelles 1839.

- A. Bex, Uit het geestenrijk van Suriname, Paramaribo 1926.

- Prince Roland Bonaparte, Les habitants de Suriname, Paris 1884.

- C. Bonne, Het Boschnegerschrift van Afaka, De W. I. Gids III 1921.

- G. Burkhardt, Die Mission der Brüdergemeinde in Missionsstunden. Zweites Heft, Suriname, Leipzig 1898.

- H. van Cappelle, Bij de Indianen en Boschnegers van Suriname, Elsevier's geïll. M. 1902.

-- C. van Coll, Gegevens over land en volk van Suriname, Bijdr. T. L. V. Ned. Indië 55, 1903.

C A. M. Coster, De Boschnegers in de kolonie Suriname, hun leven, zeden en gewoonten. Bijdr. T. L. V. Ned. Indië 1866.

- H. Coudreau, Chez nos Indiens, Paris 1893.

$\mathrm{Cr}$ J. Crevaux, Voyages dans l'Amérique du Sud, Paris 1883.

- Ch. D. Dance, Chapters from a Guianese log-book, Georgetown 1881.

- J. G. W. Eilerts de Haan, Verslag van de expeditie nacr de Surinamerivier, T. K. N. Aardr. Gen. 1910, overdruk.

Enc Encyclopaedie van Nederlandsch West-Indië (H. D. Benjamins en J. F. Snelleman), 's-Gravenhage en Leiden 1914-1917.

Fo H. C. Focke, Neger-Engelsch woordenboek, Leiden 1855.

1F A. Franssen Herderschee, Verslag van de Gonini-expeditie, T. K. N. Aardr. Gen. 1905, overdruk.

$2 \mathrm{~F}$ id. Tapanahoni-expeditie, id. 1905, overdruk.

$1 G$ C. H. de Goeje, Verslag der Toemoekhoemak-expeditie, T. K. N. Aardr. Gen. 1908, overdruk.

2G id. Suriname ontdekt, id. 1934.

- J. J. Hartsinck, Beschrijving van Guiana, Amsterdam 1770.

$1 \mathrm{H}$ M. J. and F. S. Herskovits, Rebel Destiny, New-York and London 1934.

2H id. Suriname Folk-Lore, New-York 1937.

$3 \mathrm{H}$ M. J. Herskovits, Preliminary report of an ethnological expedition to Suriname, 1928, De W. I. Gids X 1928.

$4 \mathrm{H}$ id. The second Northwestern University expedition for the study of the Suriname Bush Negroes, 1929, De W. I. Gids XI 1929.

$5 \mathrm{H}$ id. The social organization of the Bush Negroes of Suriname, Proc XXIII Int. Congress Amer. New-York 1928.

$6 \mathrm{H}$ id. Wari in the new world. J. Royal Anthr. Inst. London LXII 1932.

$7 \mathrm{H}$ id. On the provenience of new world negroes, Social Forces XII 1933. 
afkorting

$8 \mathrm{H}$ id. Freudian mechanisms in primitive negro psychology, Essays presented tot C. G. Seligman, London 1934.

9H id., Social History of the Negro, A Handbook of Social Psychology Worcester Mass. 1935.

- D. Holdridge, Escape to the Tropics, New-York 1937.

- Hoofdenverkiezing bij boschnegers in Suriname, Bijdr. T. L. V. Ned. Indië 72, 1916.

Ho F. W. Hostmann, Over de beschaving van Negers in Zuid-Amerika door kolonisatie met Europeanen, Amsterdam 1850.

- W. Joest, Ethnographisches und verwandtes aus Guayana, Int. Archiv f. Ethn. V Suppl. 1893.

1J L. Junker, Eenige mededeelingen over de Saramaccaner Boschnegers, De W. I. Gids IV 1922.

2J id. Over de afstamming der Boschnegers, id. V 1923.

$3 \mathrm{~J}$ id. De godsdienst der Boschnegers, id. VII 1925.

4J id. Het einde van een dynastie, id. XIV 1932.

$5 \mathrm{~J}$ id. Een staat in den staat, id. id.

1K Morton C. Kahn, Djuka, New York 1931 (zie hierbij 4J 267-268).

$2 \mathrm{~K}$ id. Africa's lost tribes in South America, National History, New York, April 1939.

1aKp A. Kappler, Sechs Jahre in Surinam, Stuttgart 1854.

$1 \mathrm{bK} p$ id. Zes jaren in Suriname, Utrecht 1854.

$2 \mathrm{~K}_{\mathrm{p}}$ id., Holländisch Guiana, Stuttgart 1881.

$3 \mathrm{Kp}$ id., Surinam, Stuttgart 1887.

- H. ten Kate, Beitrag zur Ethnographie von Surinam, Int. Archiv f. Ethn. I 1888.

Ko J. Kohler, Zum Negerrecht in Surinam, Z. f. vergl. Rechtswiss. 27, Stuttgart 1912 (gegevens van een Surinamer, verstrekt door F. Staehelin).

- P. H. J . Lampe, Het Surinaamsche treefgeloof, De W. I. Gids X 1928.

- H. de Leeuw, Crossroads of the Caribbean, New York 1935.

1L W. J. van Lier, Iets over de Boschnegers in de Boven-Marowijne, Paramaribo 1919.

2L id., 't Een en ander over Afkôdrai, Wisi, Bakroe, Jorka, enz., Suriname 1920.

3L id., Bij de Aucaners I, De W. I. Gids III 1922; II en III id. IV 1923.

4L id., Hoe Boni aan zijn einde kwam, De Periskoop 931926.

5L id., De invloed van het Christendom op de Matuariërs, De Herrnhutter nos. 14, 15, 161927.

6L id., Land- en Volkenkunde, De Periskoop 165, 1927.

7L id., Iets over de Rechtsbegrippen bij de Aucaners, De Emancipatie Courant 1 Juli 1930 no. 5.

8L id., Een en ander over het wisibegrip bij de Boschnegers, De Surinamer Oct. 1930.

9L id., Kandoe, De Emancipatie Courant 1 Juli 1938 No. 6.

$10 \mathrm{~L}$ id., Kina, De Surinaamsche Politie (orgaan Sur. Politiebond) 1938-40. nos. $4,11,13$ en ...

- G. Lindblom, Afrikanische Relikte und Indianische Entlehnungen in der Kultur der Buschneger Surinams, Göteborg 1924.

- J. E. Loth, Aanteekeningen over de Djoeka's (Aucaner Boschnegers) in Suriname, T. K. N. Aardr. Gen. 1910. 
afkorting

- W. L. Loth, Verslag van eene reis naar de Lawa, T. K. N. Aardr. Gen. 1893.

- A. J. H. van Lynden, Op zoek naar Suriname's Zuidgrens. De grensbepaling tusschen Suriname en Brazilië 1935-1938, T. K. N. Aardr. Gen. 1939, overdruk.

MK Ma Kankantri. Zedenkundige schets uit den slaventijd, De Surinamer 1907 (H. F. Rikken).

- K. Martin, Bericht über eineReise ins Gebiet des oberen Surinam, Bijdr. T. L. V. Ned. Indië 35, 1886.

OW Onze West in Beeld en Woord, 2e druk, Amsterdam 1929 (F. Oudschans Denz en H. J. Jacobs).

$1 \mathrm{~Pa}$ L. C. van Panhuys (over ornamenten, tatoeage en muziek der Djoeka's), Int. Archiv f. Ethn. 1898, J. Soc. Amer. Parijs IX 1912, Verhand. Int. Amer. Congres XIII (New York), XIV (Wien), XXII (Roma), XXIII (New York), XXIV (Hamburg); en $1 \mathrm{~F}$ en $2 \mathrm{~F}$, bijlage.

$2 \mathrm{~Pa}$ id., The heathen religion of the Bush-Negroes in Dutch Guiana, Verh. Congres v. Godsdienstgeschiedenis, Leiden 1913.

1P Penard (F. P. en A. P.), Surinaamsch Bijgeloof, Bijdr. T. L. V. Ned. Indië 671913.

- id. (A. P. en T. E.), Surinam Folk Tales, J. Amer. Folk-Lore XXX 1917.

- id (A. P.), Surinaamsche Volksvertellingen, Bijdr. T. L. V. Ned. Indië 801924.

- id. (A. P. en T. E.), Negro Riddles from Surinam, De W. I. Gids VIII 1926

- id. (A. P.), Lobi-singi, De Periskoop 147, 150, 152, 153, 170 1927-28.

$2 \mathrm{P}$ id. (T. E. en A. P.), Popular beliefs pertaining to certain places in Surinam, De W. I. Gids X 1928.

- Politieke contracten met de Boschnegers in Suriname, Bijdr. T. L. V. Ned. Indië 711916.

- H. G. Schneider, Die Buschneger Surinams, Allg. Missions Z. 20 1893, Beiblatt.

Schu H. Schuchardt, Die Sprache der Saramakkaneger in Surinam. Verh. K. Ak. Wet. Amsterdam Lett. XIV 61914 (met woordenboek C. L. Schumann 1778).

Sp J. G. Spalberg, Schets van de Marowijne en hare bewoners, Paramaribo 1899 .

- G. J. Staal, Het voorspel der installatie van den posthouder bij de Aucaners, De W. I. Gids III 1921.

- id., Boschneger-herinneringen. Overeenkomst met de Aucaner Boschnegers, id. IV 1922.

St G. Stahel, De expeditie naar het Wilhelmina-gebergte (Suriname) in 1926, T. K. N. Aardr. Gen. 1926-1927.

Stn F. Staehelin, Die Mission der Brüdergemeinde in Suriname und Berbice im achtzehnten Jahrhundert, Herrnhut-Paramaribo 1913 vlg. (bevat tal van mededeelingen over surinaamsche Negers, voornamelijk over Saramakkaners, o.m. II/2/248-283 Riemers Mitteilungen über die Freineger und ihre Sitten und Gewohnheiten).

- J. G. Stedman, Reize naar Surinamen, Amsterdam 1799.

- M. D. Teenstra, De landbouw in de kolonie Suriname, Groningen 1835.

- J. W. Vandercook, Tam-Tam, vert. Albert Helman, Amsterdam 1935 (zie nog 4J 268). 
afkorting

Ve G. Versteeg, Op expeditie in Suriname, Elsevier's Geill. M. 1905.

- Vidal, Voyage d'exploration dans le Haut Maroni. Revue mar. et col., Paris 1861, extrait 2me éd. 1882.

- J. Wolbers, Geschiedenis van Suriname, Amsterdam 1861.

- E. Wong, Hoofdenverkiezing, stamverdeeling en stamverspreiding der Boschnegers van Suriname in de $18 \mathrm{e}$ en $19 \mathrm{e}$ eeuw, Bijdr. T. L. V. Ned. Indië 97, 1938.

Wu H. R. Wullschlägel, Deutsch-Negerenglisches Wörterbuch, Löbau 1856 (correcties in tijdschrift West-Indië I p. 305). 


\section{WOORDREGISTER.}

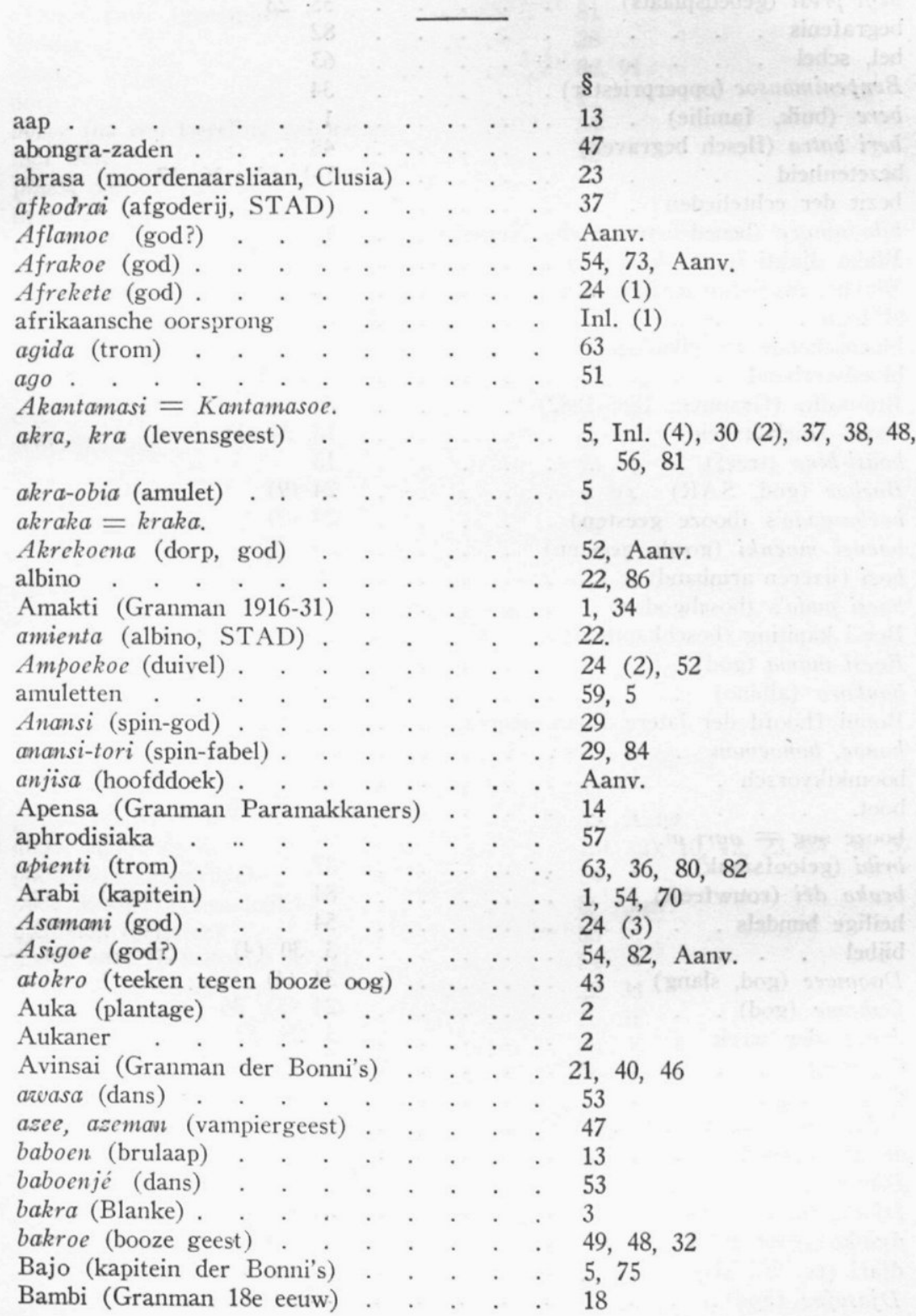

D1. 99. 


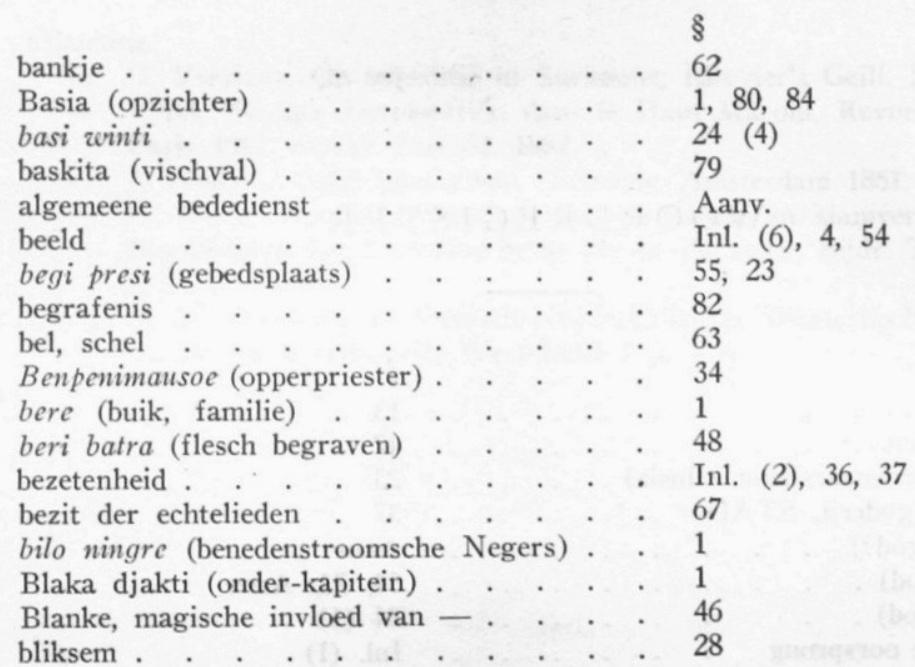

bloedschande $=$ pikadoe.

bloedsverbond . . . . . . . . zie eed

Blijmoffo (Granman 1865-1882) . . . . 70, 82

boasi (melaatsheid) . . . . 13, 24 (1)

boasi-kina (treef) . . . . . . . 13

Boeboe (god, SAR) . . . . . . . $24(9)$

boeba-gado's (booze geesten) . . . . . 24 (2)

boensi moenki (goede geesten) . . . . 24 (13)

boei (ijzeren armband) . $. \quad . \quad . \quad . \quad . \quad 59$

boesi gado's (boschgoden) . . . . . . . 23

Boesi kapiting (boschkapitein) . . . . . 1

Boesi mama (god) . . . . . . . . . 22

bonkoro (albino) . . . . . . . . 22

Bonni (hoofd der latere Bonni-negers) . . 40, 57, 70

bonoe, bonoeman. . . . . . . . zie obonoe

boomkikvorsch . . . . . . . . 26

boot. . . . . . . . . $66,67,76$

booze oog = ogri ai.

bribi (geloofszaak) . . . . . . . . 37

broko déi (rouwfeest) . . . . . . . . 84

heilige bundels . . . . . . . . . 54

bijbel . . . . . . . . . . 3, 30 (4)

Dagowee (god, slang) . . . . . . . 24 (4)

Dahome (god) . . . . . . . . . 24 (5), 36

dagen der week . . . . . . . . 5, 25, 52

dampbad . . . . . . . . . . 72

dansen . . . . . . . . . 53, 76

dedde hoso (rouwfeest STAD) . . . . 91

diergroepsgeest . . . . . . . . Inl. (2), 23

Dinga (god) . . . . . . . . . $24(6)$

Djadja (god, tijgerkat) . . . . . . . 24 (7)

djanko (gier SAR) . . . . . . . 24 (17)

djari (erf STAD) . . . . . . . . $24(4)$

Djasofoe (god). . . . . . . . . 24 (8) 


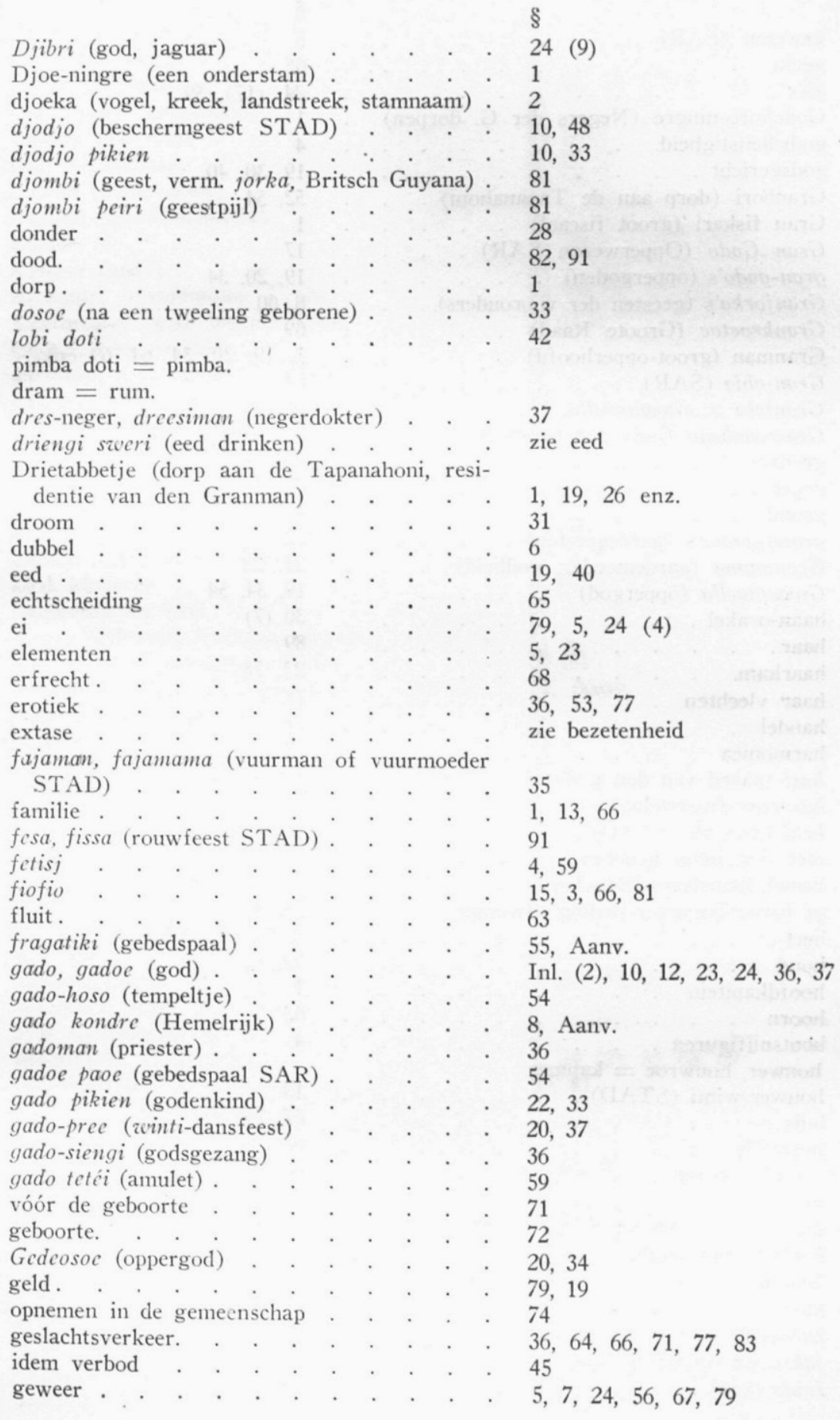




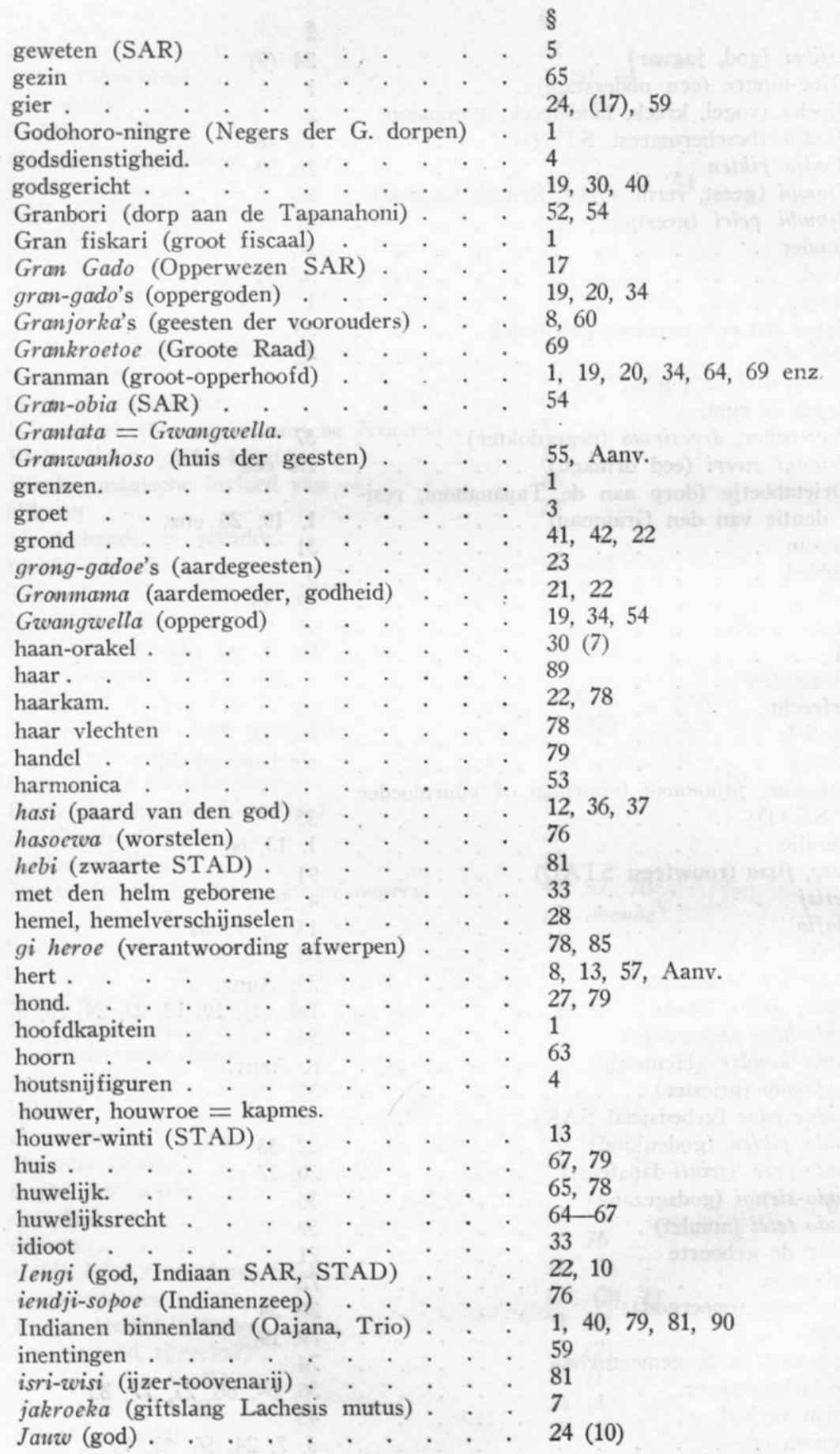




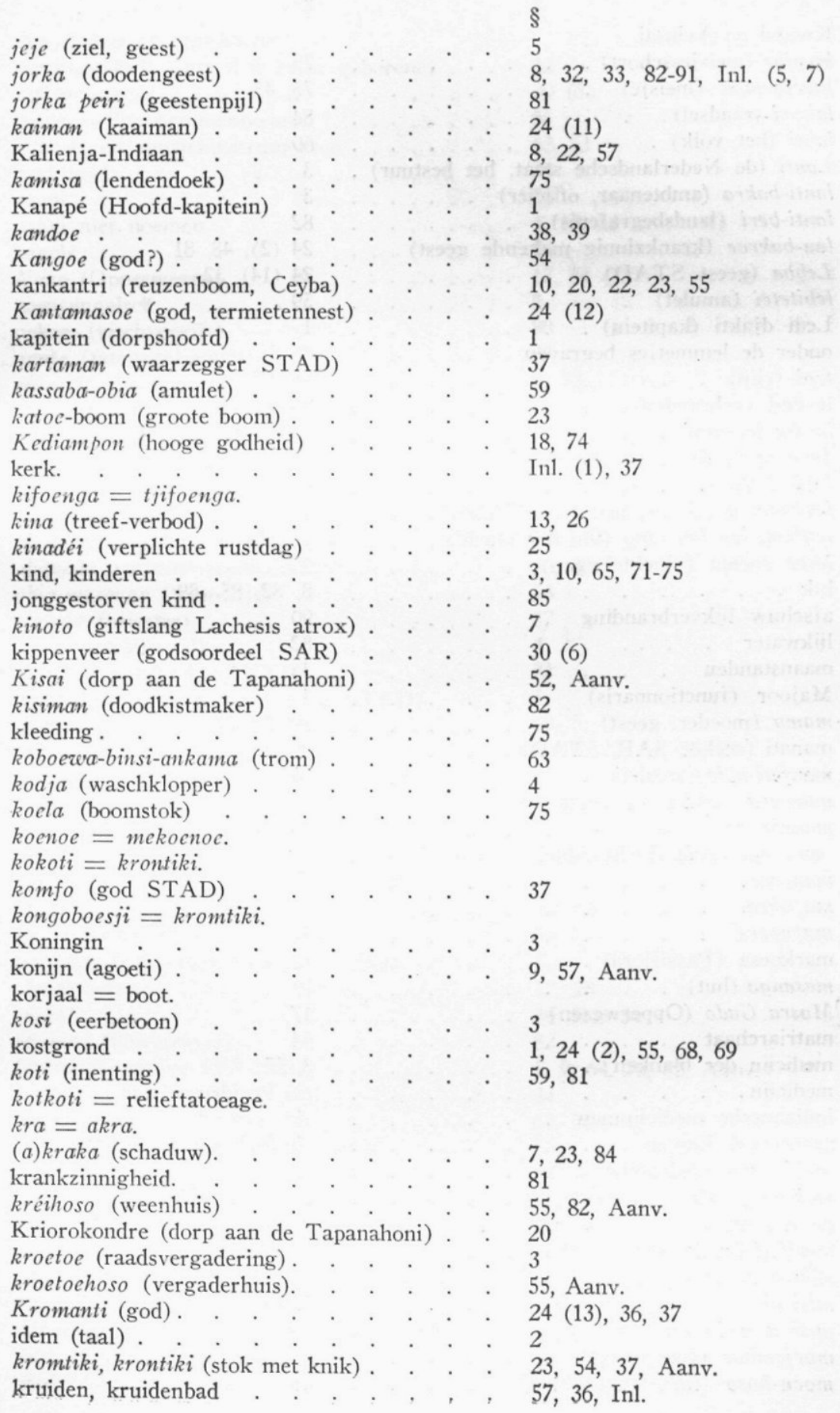




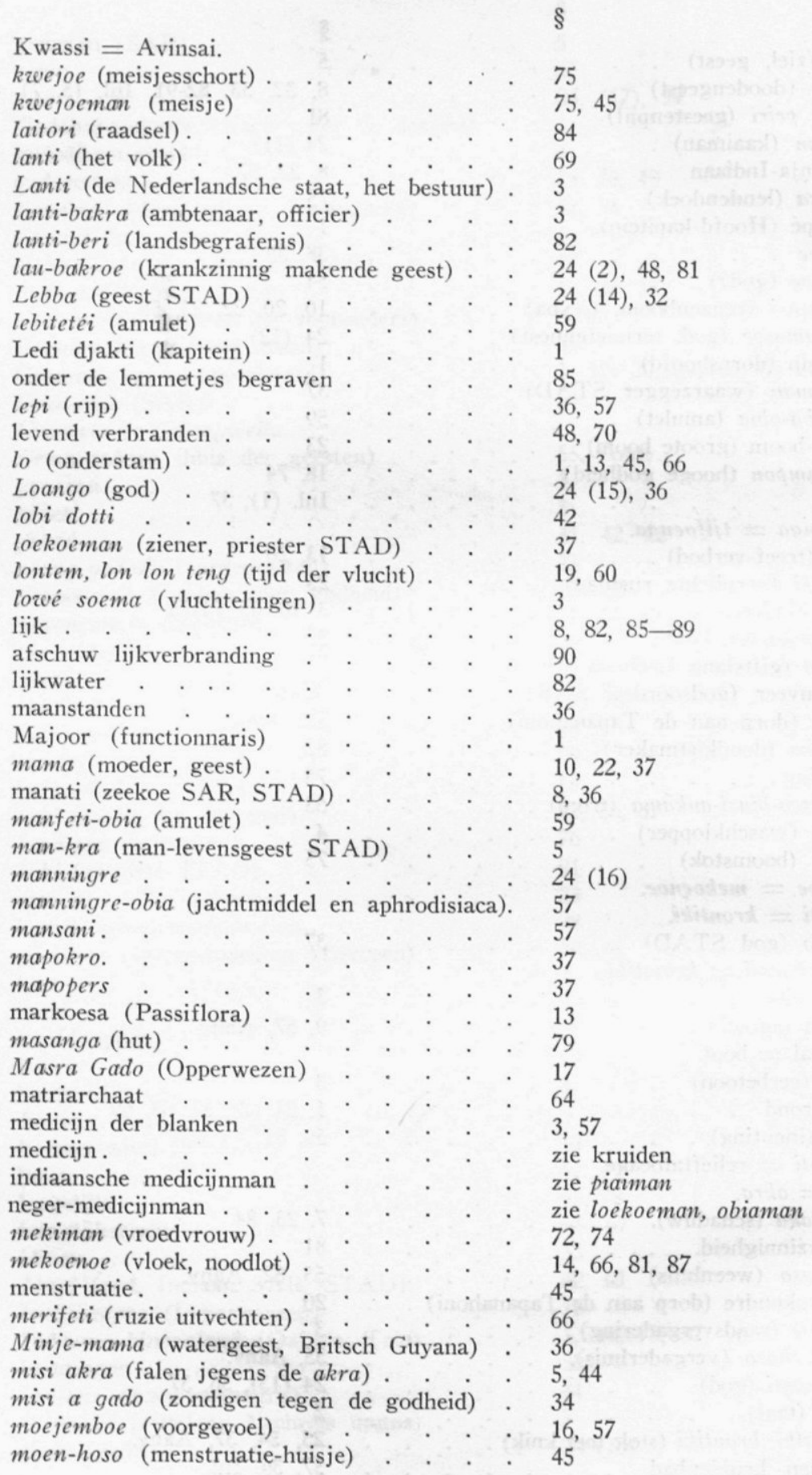


moentjama $=$ regenboog.

moesoe-pikien (met den helm geborene). . 33

seti monsonio . . . . . . . . . . 30

mope (wilde pruimenboom) . . . . . . 55

muziek en muziekinstrumenten . . . . 63,53

naaktheid . . . . . . . . . . . 75

naam . . . . . . . . . . . . 73

naam niet noemen . . . . . . . . $4,13,23$

nagels . . . . . . . . . . 89

Nana (Opperwezen) . . . . . . . . 17, 24 (13)

negerengelsch . . . . . . . . . . 2

nekoe (vischvergift) . . . . . . . . 80

ngate (tatoeagefiguur) . . . . . . . . . 77

ninseki (naamgenoot) . . . . . . . . . 9, 73

nịjverheid . . . . . . . . . . . 79

njankoe boei (amulet) . . . . . . . Aanv.

obia (magische macht). . . . . . . Inl. (3), 36

obia .

zie kruiden en amulet

obia-hoso (tempeltje) . . . . . . . . 54

obia-kedere (amulettrommeltje) . . . . . 59

obiaman (priester-medicijnman) . . . . . 36, 37

obia-masanga (tempeltje) . . . . . . . 54

obonce (priester) . . . . . . . . . 37

odo (spreekwoord) . . . . . . . . . 4

Odoen (oppergod BONNI) . . . . . 21

oeman-kra (vrouw-levensgeest STAD) . . 5

offeren . . . . . . . . . . 60,5

offerplaats . . . . . . . . . . . $\quad . \quad 1,10,23,54,55,71$

ogri ai (booze oog) . . . . . . . . . . . 43

onderwijs . . . . . . . . . . . . 76

ondro watra-gado's (onderwatergoden) . . 23

oom. . . . . . . . . . . . 64,64

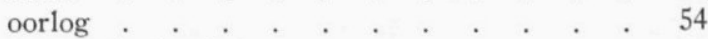

Opete (god, gier). . . . . . . . 24 (17)

opo (amulet STAD) . $. \quad . \quad . \quad . \quad . \quad . \quad 59$

opo-ningre (bovenstroomsche negers) . . . 1

Opperwezen . . . . . . . . . . 17,28

orakel . . . . . . . . . . . . 30 (1), 54

oroman (doodgraver) . . . . . . . . 82

Oséisi (Granman 1888-1915) . . . . 1, 9, 64, 70, 82, Aanv.

Otterlo (onderstam) . . . . . . . . 34

overspel. . . . . . . . . . . . . 64,70

pandje, panji, pangi (kleedingdoek) . . . 75

pantakre (bakove-soort) . . . . . . . 68

papadron (trom) . $. \quad . \quad . \quad . \quad . \quad . \quad . \quad .63$

Papa gado (god) . . . . . . . . . 24 (4), 4

papa moni (kauri-schelp) . . . . . . . 5, 59

papa sncki (soort boa-slang) . . . . . . 24 (4), 4

papaai (draagbaar). . . . . . . . . . 82

papegaai. . . . . . . . . . . . . . 26, 79

paritiki (roerspaan) . . . . . . . . . 78

Pedri-lo (onderstam) . . . . . . . . . 34 


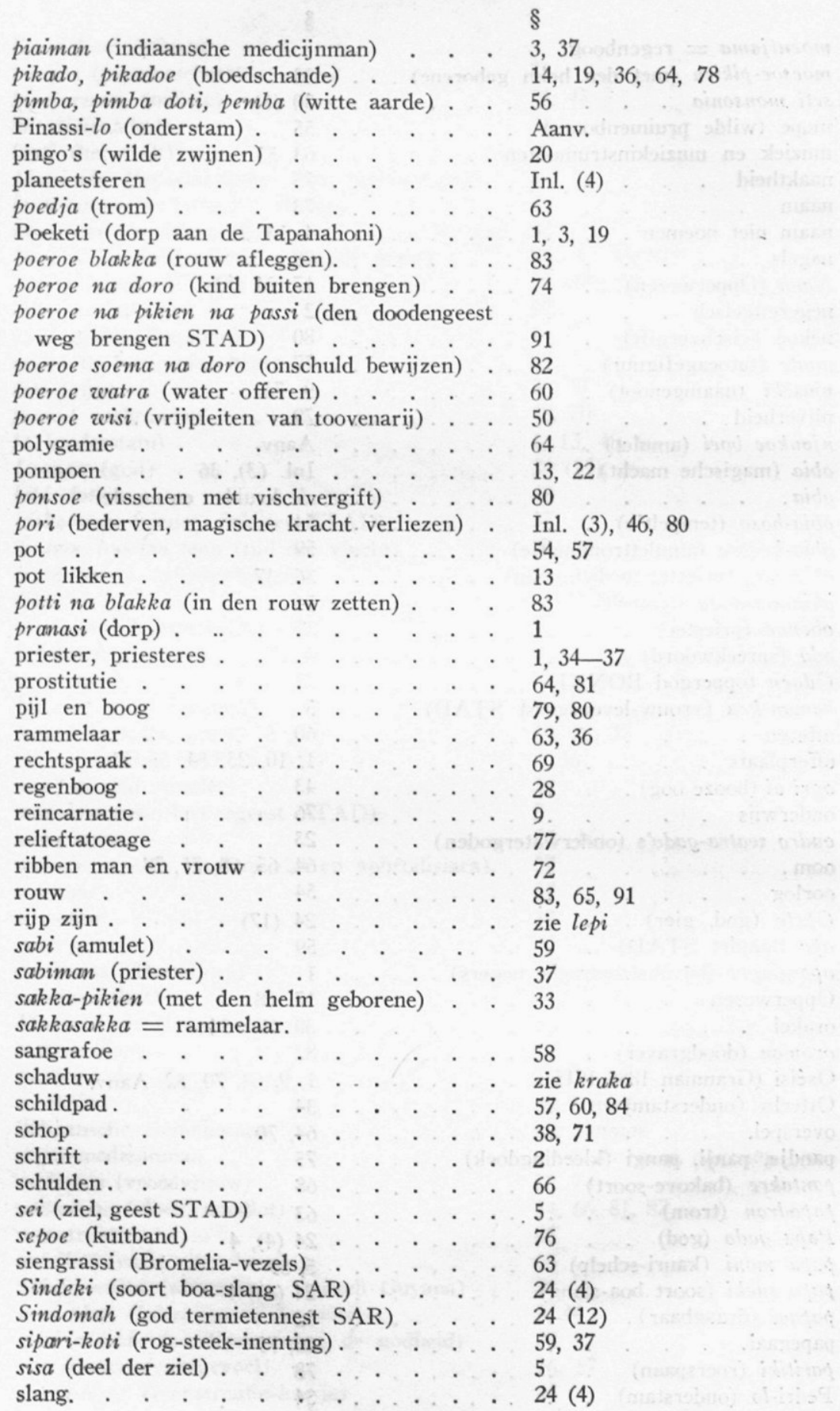




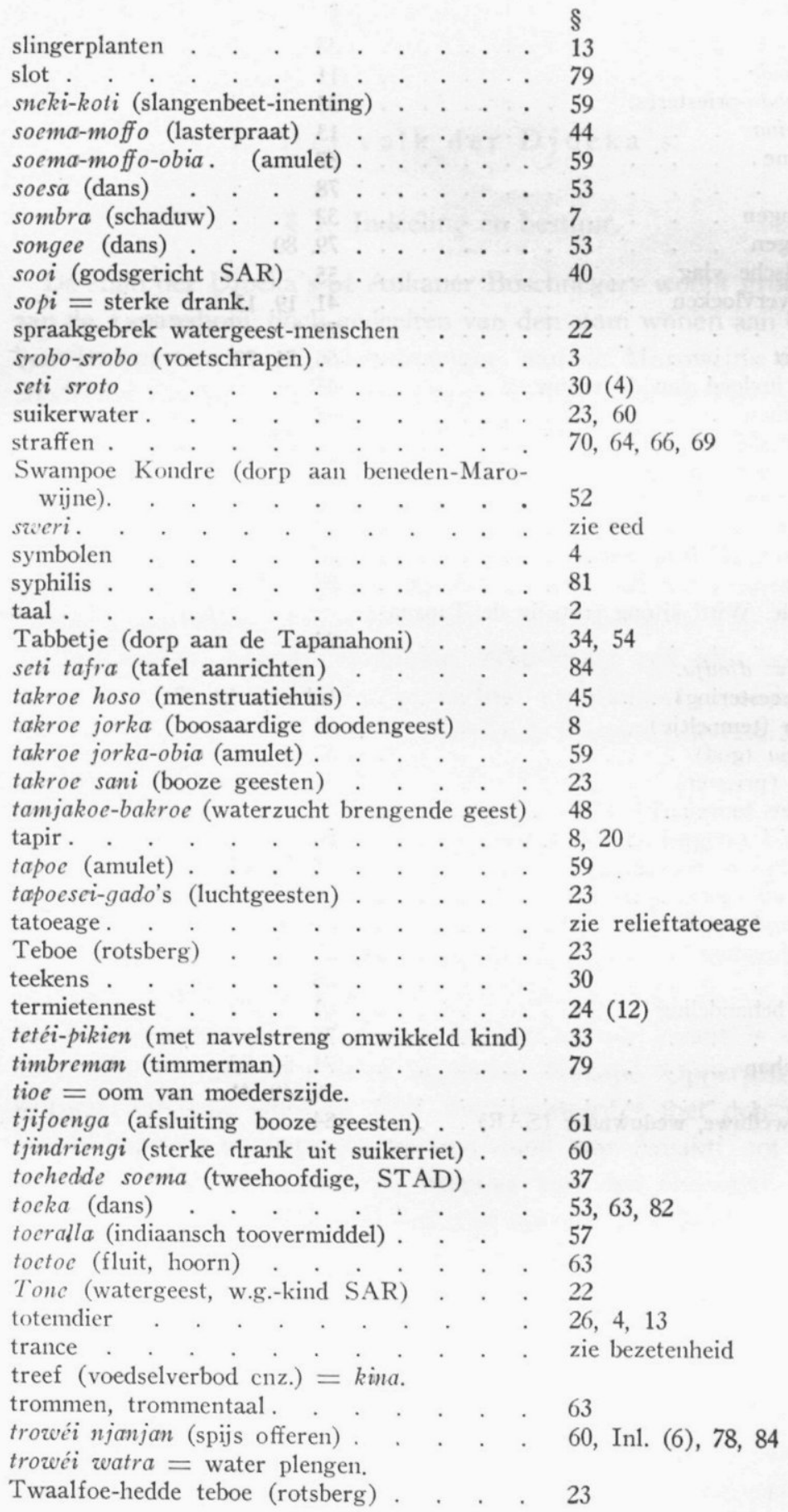




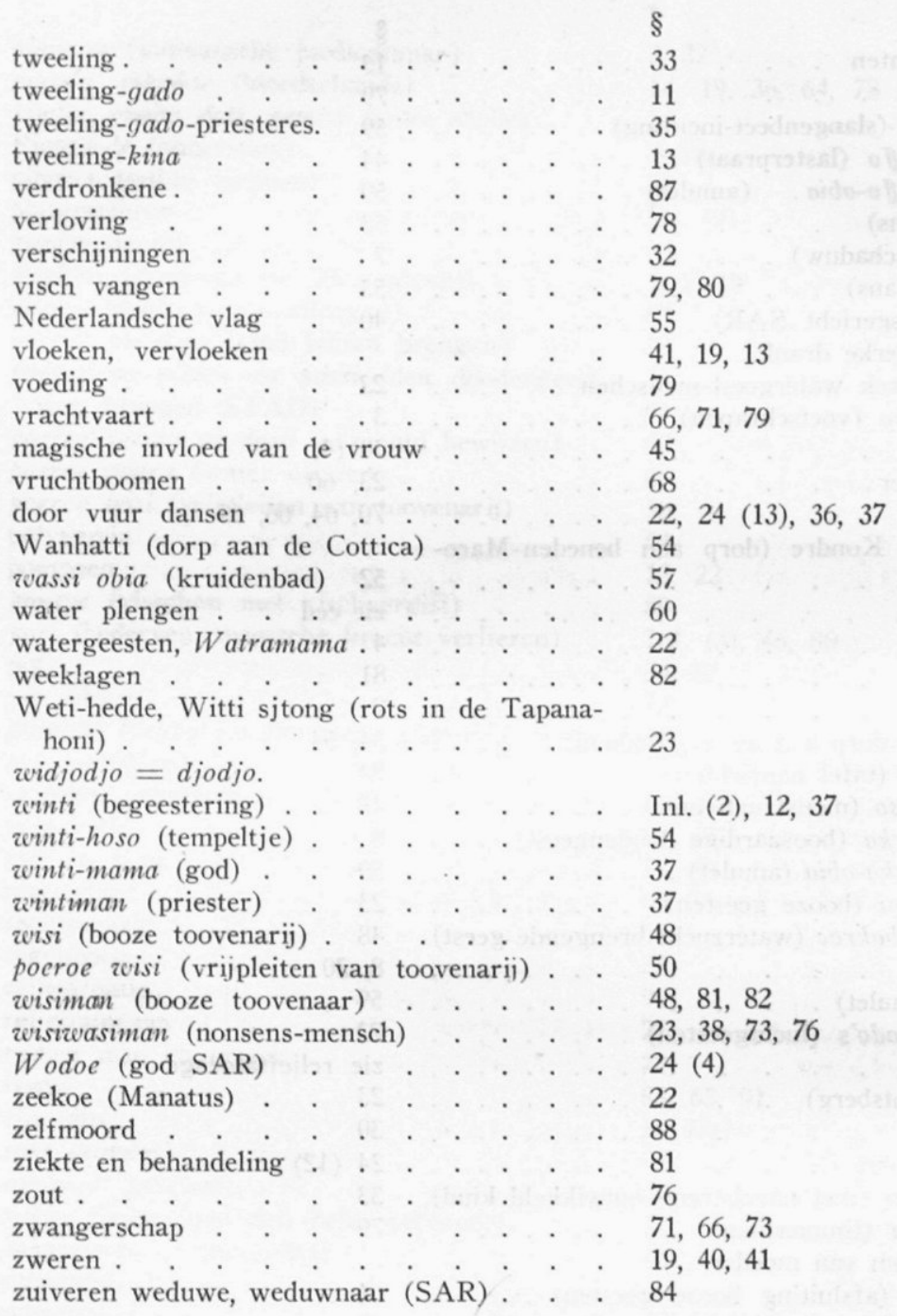


I. Het volk der Djoeka's.

\section{$\S 1$. Indeeling en bestuur.}

De stam der Djoeka's of Aukaner Boschnegers woont grootendeels aan de Tapanahoni, doch gedeelten van den stam wonen aan de Lawa benedenwaarts van val Abonasoengoe, aan de Marowijne (met uitzondering van het gedeelte van Langa Tabbetje tot de Pedrosoengoeen Apoma-vallen, waar de Paramakkaner Boschnegers wonen), aan de Sara-kreek en aan de Cottica. Voor de geschiedenis van dit volk zij verwezen naar Wolbers, Enc, Wong, 1L 1 vlg., 37 vlg., 1G, J. E. Loth.

Aan het hoofd van den geheelen stam staat de Granman, het Groot Opperhoofd, wiens residentie Drietabbetje is. Op die plaats worden sedert Amakti (Granman 1916-1931) ook alle belangrijke vergaderingen op godsdienstig, rechts- en maatschappelijk gebied, gehouden. Vroeger was de vergaderplaats Poeketi (zie ook 3L I 24) en nog vroeger woonden daar de Granmans.

De Granman is tevens Opperpriester ( $\S 34)$ en wordt onfeilbaar geacht, behalve wanneer hij zondigt tegen de wetten van Grantata (§ 19). Niets, hetzij geestelijk of sociaal, wordt er verricht, dat niet in den naam van den Granman geschiedt. Een offerplaats wordt ingericht, de kamisa wordt uitgereikt ( $\S 74)$, een boot wordt te water gelaten, een huis gebouwd, enz. enz.; het geschiedt steeds in naam van den Granman. Toen Amakti aan het bestuur kwam, is echter de door zijn voorganger Oséisi opgeleide Kanapé Opperpriester geworden; en deze werd in 1921 medebestuurder met den titel van Hoofd-kapitein en vervulde na den dood van Amakti, tot in 1937 Amatodjo Granman werd, de functies van den Granman. (Foto's Oséisi Van Cappelle 241, de straks te noemen kapitein Arabi 2F 81, Ve 321, Amakti 3L I 16, II 208, Kanapé 3L II 108).

Als hulp voor het wereldlijk gezag, in het bijzonder de justitie, is er voorts nog de Gran-fiskari (indertijd een voor de boven-, en een voor de benedenrivier, 1G 32), en vroeger de Majoor (2F 124).

Kapiteins en andere waardigheidsbekleeders onder de Boschnegers mogen den man, dien zij als hun opvolger wenschen, aanbevelen, doch die kan pas benoemd worden, als hij door de ouderen van de 
lo, waar hij optreden zal, daarvoor gekozen wordt, en de Granman die verkiezing goedkeurt. Gévallen, dat een Granman een dergelijke verkiezing niet goedkeurde, zijn niet bekend. Alleen de Granman heeft het recht zelf zijn opvolger aan te wijzen, doch men kan, zie $\S 82$, als hij overleden is, het nog nader vragen aan zijn jorka. De aanwijzing van een nieuwen Granman is aan de goedkeuring van het Surinaamsch Bestuur onderworpen.

De stam is verdeeld in 12 onderstammen, $l o$ geheeten $\left.^{1}\right)$. De 12 $l o$ 's staan als partijen vaak tegenover elkaar; de Granman is partijloos en men zegt wel dat de Granman de $13 \mathrm{e}$ lo is, omdat hij niet onderworpen is aan de $l o$ waartoe zijn familie behoort. [Ietwat anders bij Wong 315; deze geeft 14 lo's op; zie ook J. E. Loth 341.]

Aan het hoofd van iedere lo staat een Gran kapiting (groot-kapitein), die den titel Ledidjakti (roodjas) voert. Hij wordt bijgestaan door een Onderkapitein, den Blaka djakti (zwartjas), die ook zijn vervanger is. Op dezen volgt de Boesi kapiting (bosch-kapitein), die de leiding heeft van den dagelijkschen gang van zaken.

Een $l o$ omvat meestal meerdere dorpen, die soms ver uit elkaar liggen. Op elk dorp is er een Basia (hoofdman; afkomstig van bastiaan = slavenopzichter ; zie ook $\S \S 80,84$ ), die het gezag vertegenwoordigt. De Blakadjakti en de Ledidjakti wonen meestal niet op hetzelfde dorp; op het dorp waar zij wonen, is er niettemin ook een Basia. De functie van den Basia is min of meer die van burgemeester en commissaris van politie; hij geeft ook de orders uit voor de gemeenschappelijke werkzaamheden en voor de heerediensten voor den Granman (n.l. voor het jaarlijks kappen van grondjes voor den Granman, waarvoor elke $l o$ een aantal mannen moet leveren), huizen bouwen, bootenmaken en jagen en visschen voor een groot feest.

Op een dorp wonen meerdere families tezamen; in den regel wonen van een bepaalde familie alle leden op hetzelfde dorp, behoudens dan, dat een man, gehuwd met een niet op het dorp wonende vrouw, bij die vrouw zal wonen. Het hoogste gezag in elke familie berust bij den oudsten man in jaren, die tegelijk ook de raadgever in particuliere aangelegenheden is.

$\mathrm{Er}$ is een indeeling der lo's in twee groepen: de ópo-ningre (bovenstrooms-negers), hoofdzakelijk wonende van Sangamasoesa stroomopwaarts, die in het bijzonder bij de godheid Grwangwella behooren;

1) Lo wordt wel gehouden voor negerengelsch $l o=$ engelsch row, doch wellicht is het woord afrikaansch, zie Lindblom 99, 1H 351. De lo's voeren de namen van vroegere plantages of plantage-eigenaars, zie Wong. 
en de biló-ningre (benedenstrooms-negers), hoofdzakelijk wonende benedenstrocms van Sangamasoesa, die in het bijzonder bij de godheid Gedeosoe behooren. Sedert de tweespalt tusschen Granman Oséisi en kapitein Arabi (1L, 1G 32 vlg.) is er een derde groep, die der Godohoro-ningre, van het Godohoro-dorpencomplex (lo der Djoe-ningre).

Het geheele vasteland en alle eilanden in de rivieren waar Djoeka's wonen, is verdeeld tusschen de $l o$ 's, met onderverdeeling naar de dorpen (pranasi $=$ plantage) en vervolgens weder naar de families (bere $=$ buik).

De grens is veelal een groote kreek, of een denkbeeldige lijn die vanuit een waterval of een eiland in de rivier, haaks op den oever, het land in loopt.

Wat boven het bovenste en beneden het benedenste Djoeka-dorp ligt, is domeingrond van den Granman; vroeger strekte men dat zelfs uit tot aan de zeekust en de bovenrivier beschouwen zij nog steeds als eigendom van den Granman. Vandaar dat men vroeger wel aan balatableeders en goudzoekers enz. den doorgang verbood en gedeelten van de rivier afsloot voor de Indianen van het bovenland of bij wijze van straf voor bepaalde personen of een bepaalde $l o$. Als er het een of ander gevaar dreigde, kwam het voor, dat de Granman alle vaart, bijv. op de bovenrivier, verbood : ,passi tapoe”. De Oajánaen Trío-Indianen van de boven-Tapanahoni en Paloemeu acht men ondergeschikt aan den Granman der Djoeka's en evenzoo achten de Bonni's de Oajana's van de Litani ondergeschikt aan den Granman der Bonni's.

De Lawa en bronrivieren vanaf de Abonasoengoe-vallen worden gerekend aan de Bonni's te behooren; beneden Abonasoengoe is het gebied der Djoeka's. Deze kappen zich dikwijls grondjes aan de Lawa, omdat door den roofbouw de goede grond wat schaarsch is aan de Tapanahoni. Bij zoo'n grondje ontstaat dan soms een blijvend dorp, zooals Gransanti, dat al een eeuw oud is. De Lawa-grondjes zijn aangelegd door bilo-negers; de opo-negers die men er vindt, zijn opo-mannen, die met een aldaar wonende bilo-vrouw getrouwd zijn.

Die nederzettingen aan de Lawa gelden niet als eigenlijke dorpen. Het grondje is oorspronkelijk door een familie gesticht, welks naam het dikwijls nog draagt; daar kunnen zich anderen bij hebben gevoegd. De oudste man van de familie die het gesticht heeft, oefent het gezag uit. Aan de Lawa staan ze min of meer buiten het gezag 
van den Granman en de lo's; is er echter iets van hun lo of van den siam, waar ze bij moeten zijn, dan worden ze opgeroepen. Dat deze menschen aan de Lawa wonen, wordt in het algemeen niet goedgekeurd door de Granmans en het heeft vaak aanleiding gegeven tot ernstige botsing tusschen Granman en bilo-kapiteins. Meermalen heeft de Granman verboden om nieuwe grondjes te kappen aan de Lawa, welk verbod hij echter niet kon handhaven, omdat hij op het vertoog der bilo-kapiteins om dan grond aan de boven-Tapanahoni aan te wijzen, in gebreke moest blijven.

De dorpen der Djoeka's aan de Sara-kreek, Cottica en Commewijne, gelden als gewone dorpen, doch wegens den grooten afstand zijn verschillende bevoegdheden van den Ledidjakti gedelegeerd aan de plaatselijke ouderen. Zeer belangrijke zaken moeten echter beslist worden daar waar het hoofd van de lo zetelt.

De Djoeka's van de Sara-kreek verschillen nogal, in zeden en gewoonten, van de anderen; wellicht, doordien zij tijdens de vlucht daar gebleven zijn, terwijl de anderen verder trokken naar Djoekakreek en Tapanahoni; doch ook hun omgang met de naburige Saramakkaners zal van invloed zijn. De Djoeka's van Cottica en Commewijne zijn eerst later derwaarts getrokken.

\section{§ 2. Oorsprong van den naam D joeka; taal; schrift.}

De weggeloopen slaven, voorouders der Djoeka's, die in de $18 \mathrm{e}$ eeuw van de boven-Tempati naar het Zuiden trokken, vonden voor het eerst rust in het dal van de Djoeka-kreek. Tot hun groote verbazing zagen ze daar in grooten getale een kleinen vogel, die naar zij meenden, een hun bekende vogel uit Afrika was, djoeka geheeten. Het was hun een teeken, dat de goden hen uit Afrika naar hier waren gevolgd.

Dit is, naar men zegt, de oorsprong ervan, dat elk lid van dezen stam zichzelf, en ook den geheelen stam en eveneens hun woonstreek aan de Tapanahoni, „Djoeka” noemt. De kreek waaraan ze zich het eerst vestigden, welke uitmondt in de Marowijne, heet nog tegenwoordig Djoeka-kreek.

Den naam Aukaner gebruiken deze menschen zelve niet. Die naam is afkomstig van de plantage Auka (2G kaartje) vanwaar een pad naar hunne nederzettingen ging (5J 277, Wong 303, 352).

De gewone taal der Djoeka's is het Negerengelsch, met enkele woorden die verschillen van het Negerengelsch van Paramaribo. 
In den toestand van bezetenheid spreken ze, naar het heet, Kromanti, dat van afrikaanschen oorsprong zoude zijn; zie $\S \S 36,37$ en 1L 10, Enc 160, Sp 39, 1H 312, $2 \mathrm{H}$ 66, 531 vlg.

Het Djoeka-schrift voor het Negerengelsch, waarvan Bonne en $1 \mathrm{~K}$ 205-207 staaltjes geven, is, naar het schijnt, niet van ouden datum, en geenszins in algemeen gebruik.

\section{$\S 3$. Karaktereigenschappen.}

De Boschneger over het algemeen, doch vooral de Djoeka, is trotsch. Aan menschen van den eigen stam zal men nooit iets bedelen, en in geen geval aan lieden van een anderen Boschnegerstam. Daarentegen ziet men er niets in, en is het zelfs een gewoonte, om van Blanken en Stadsnegers te bedelen. Indianen beschouwen ze als een lager ras. De Stadsnegers en halfbloeden zullen in voorkomende gevallen zich tot den indiaanschen medicijnman (negerengelsch piaiman) wenden; de Boschneger doet dat nooit.

(In 1904 was ik te Oreala aan den britschen oever van den Corantijn, waar gekerstende Indianen wonen. Een Stadsneger die daar met een landmeter kwam, wendde zich tot een ván die Indianen om hem een toovermiddel te bereiden om zich succes bij de vrouwen te verzekeren. De Indiaan vorderde daarvoor f 12.50 , en op een Zondag bracht hij aan den Neger een paket en verzocht hem dit in tegenwoordigheid van alle aanwezigen te openen; dat zou voor hem, als medicijnman, tot reclame dienen. - Toen de Neger het pak opende, vond hij er een Bijbel in! Volgens den Indiaan bevatte het pak alles wat de Neger ooit maar noodig zou kunnen hebben).

De Boschnegers zijn zeer gierig, en dat zelfs tegenover hun eigen vrouwen en kinderen. De vrouwen zijn echter als regel minder gierig dan de mannen; vele zijn zelfs goedgeefsch. Allen, mannen en vrouwen zijn zeer hebzuchtig en ongegeneerd in het bedelen als ze bij een niet-Boschneger iets zien dat hen bekoort, of dat ze noodig hebben.

Dankbaarheid kent de Boschneger over het algemeen niet; dankbaarheid is uitzondering. Doch als zij zelf een dienst aan een ander bewijzen, dan meten zij dat breed uit. $Z_{\mathrm{ij}}$ meenen dat zij van de bakra's (blanken) zoo veel mogelijk moeten trekken en wat „Lanti” (het Gouvernement) betreft, zijn ze van meening, dat dit, als ze te Paramaribo zijn, verplicht is hen te onderhouden en vooral om hun medicijnen, waar ze zeer op gesteld zijn, bij groote hoeveelheden te verstrekken. Daartegenover zijn ze ook gehecht aan de Blanken, vooral 
aan de nederlandsche vlag en in het bijzonder aan de Koningin. Het symbool van de vlag begrijpen ze volkomen.

Wie op een Boschnegerdorp komt, krijgt er altijd goed logies, dat behoorlijk wordt schoongemaakt en soms wordt den bezoeker zelfs drank aangeboden. Men speculeert er echter wel op, dat de bezoeker wat levensmiddelen, of vooral tabak zal geven, als tegenbeleefdheid.

De Boschnegers zijn gezellig in den omgang, over het algemeen vroolijk, en ze hebben veel zin voor humor. Een Boschneger kent geen rancune. Fiofio ( $(15)$ wordt in de hand gewerkt, doordien men geen rancune heeft en erop vergeet, dat er iets hangende is geweest en verzuimd werd de ceremoniën te verrichten om dat uit de wereld te helpen.

Alle Boschnegers, mannen en vrouwen, verlangen kinderen te krijgen; het grootste leed voor een vrouw is onvruchtbaarheid. Kinderloosheid is een aanleiding tot echtscheiding. Miskraam komt dikwijls voor, ook dat een kind dood geboren wordt, en er is veel kindersterfte.

De Boschneger is niet hulpvaardig. Is bijv. een man ernstig ziek en moet hij vervoerd worden en er is geen familie die hem helpt, dan zullen, hoeveel mannen er ook ledig rondloopen, deze er toch niet aan denken hem te helpen. Alleen bij sterfgevallen, van begrafenis tot bloko déi, zal iedereen medewerken, maar dat is een godsdienstige plicht.

De Djoeka is zeer onderdanig, op het vleierige af, tegen den Granman en ook tegen kapiteins en in het algemeen tegen ouderen. [C 10: Het is vooral de ouderdom, dien ze hooge vereering toedragen. d.G. 1937: Een Djoeka, mij toesprekend, sleepte met de voeten over den grond (kosi). STAD srobosrobo of srepi foetoe voeten sleepen, kosi kniebuiging der vrouwen].

Men is zeer precies op groet en antwoord [vgl. 1G 58].

Als een ,lanti-bakra” (lands-blanke, ambtenaar of officier) zal aankomen op het dorp van een Boschneger-autoriteit, dan behoort hij zich eerst te laten aanmelden en af te wachten tot het antwoord komt. Voor den Granman te Drietabbetje, boven de Granholo-vallen, is de wachtplaats het dorp Poeketi aan den voet dier vallen (in 1861 2K 316 en Vidal 29; in 1904 2F 25; in 1907 1G 26).

Hun gebruik om ceremonieel in acht te nemen en hun breedsprakigheid komen vooral tot uiting bij de kroetoe (raadsvergadering, vergaderen). Voor elke beslissing van eenig belang moet een 
kroetoe gehouden worden, waarbij men eindeloos lang praat, zie $3 \mathrm{~L}, 1 \mathrm{~L} 40$ vlg., Ve 320 , $1 \mathrm{G} 35 \mathrm{vlg}$. Een verzoeker en degene tot wien het verzoek gericht wordt, spreken niet rechtstreeks tot elkaar, doch er is een tusschenpersoon, ,na soema di sidon jere”, de man die zit te luisteren, en dikwijls gaan er een paar even buiten de vergadering om te overleggen wat zij zullen zeggen. 1L 90-93 en 10L geven een uitvoerige beschrijving hoe het daarbij toegaat.

Het algemeene wantrouwen tegen de Blanken is nog lang blijven bestaan; d.G. dagboek afreis Tapanahoni 23 Nov. 1904: Ik praat veel met de Djoeka's. Ze zijn nu zeer vriendelijk en in het geheel niet terughoudend. - „Waarvoor vrees en waarvoor al die leugens?" (n.l. toen de expeditie de Tapanahoni opvoer naar het Indianenland). - „Ja, we waren bang; masra moet weten, we zijn lowé soema (wegloop menschen) en hebben niet graag, dat men het land boven onze woonplaats zoo kent”. Zie ook (SAR 1926) Sta 575.

\section{$\S 4$. Godsdienstig leven en symbolen.}

De godsdienst beheerscht het geheele leven van den Djoeka; ik heb het dikwijls zoo uitgedrukt, ,dat het geheele leven van den Djoeka, van de wieg tot het graf, één lange godsdienstoefening is". Met eerlijke overtuiging en oprechte vroomheid belijden deze menschen hun geloof. [Hier zij nog aangehaald StnII/2/185 plantagenegers: Den Gado- oder Göttergesang stimmen die Neger für gewöhnlich auf allen Wasserreisen an .... Die besonderen Gebete, die sie gewöhnlich vor Antritt einer Reise zu ihren Gott schicken, sind zuweilen so bündig und zweckmässig, dass man davon gerührt wird, und sie mit ihren hirnlosen Begriffen von Gottheit nicht zusammen reimen kann.]

Men aanbidt den gado (god) wiens toorn men wil verzoenen of wiens hulp men wil verzoeken, of offert aan dien gado, die het bovenzinnelijke deel van dat offer neemt. In dat geestenrijk en bij de inwerking daarvan op onze stoffelijke wereld gelden onze begrippen van ruimte, getal en tijd niet.

Dat de Djoeka's aan fetisjdienst zouden doen, is onjuist ${ }^{1}$ ). Volgens hen bestaat niets uit stof alleen; men vereert niet het stoffelijk

1) Al naar gelang van de beteekenis die men aan het woord ,fetisj” hecht (zie hierover de Encyclopædia of religion and ethics, Edinburgh-New York 1912, onder Fetishism), kan men zeggen, dat de Boschnegers niet, of juist wel, aan fetisjdienst doen; zie ook $\S \S 54,59 .-$ d. G.

D1. 99. 
voorwerp, doch de geest die erin aanwezig wordt geacht. Alle gado's zijn onzichtbare wezens, te hoog verheven boven den mensch, dan dat ooit een menschelijk oog ze zou kunnen zien (zie nog 1L 28-39). [Betreffende de palen waarvan het bovengedeelte ruw is besneden als een menschelijk aangezicht, zegt 2K 210: De Boschnegers maken het schoonste houtsnijwerk, doch geven zich geen moeite hun afgodsbeelden zoo te versieren. Bij vorige expedities kreeg ik op mijn vragen hierover twee antwoorden. Een maker van een afgodsbeeld zeide, dat hij geen idee had hoe de god er werkelijk uitzag, en daarom zijn gelaat niet nauwkeurig kon weergeven. En bovendien was het houten beeld slechts een rustplaats voor den geest der godheid en niet de god zelf. Een ander zeide nadrukkelijk, dat indien de god een goede geest was, hij er niet om geven zou of men zich bijzondere moeite had gegeven om zijn zinnebeeld mooi te maken, terwijl als hij een kwade geest zou zijn, hij dat zou blijven, onverschillig wat men deed.]

Bij allerlei ceremoniën van den godsdienst komen symbolen te pas. Ook overigens maakt men veel gebruik van symbolen. In het houtsnijwerk heeft elke figuur een bepaalde beteekenis. Een dierfiguur duidt meestal op het totemdier (\$ 26) van dengene die het snijwerk gemaakt heeft of van dengene voor wien het bestemd is. De vele slangefiguren op houtsnijwerk, meestal aan deuren en voorgevel van de hutten, stellen de papa-sneki (papa-slang, § 24) of papa-gado voor; het is bedoeld als vereering en in ruil verwacht men bescherming, of althans dat deze godheid geen ziekte, misgewas of rampen zal zenden.

De jonge man drukt in houtsnijwerk zijn liefdesverklaring uit; het jonge meisje dat op zijn verzoek zijn haar vlecht, geeft in de figuren haar antwoord $(\S 78)$. Een man schenkt aan de moeder van zijn overleden vrouw tegen het einde van den rouwtijd een kleerenklopper (kodja) die bij de wasch gebruikt wordt; de figuren erop vertolken de diepe rouw en het leed dat hij draagt. Op een anderen kleerenklopper of een ander huishoudelijk voorwerp dat een man bij het huwelijk zijn bruid aanbiedt, kan men lezen van de hoop en het vertrouwen waarmede hij haar trouwt. Ook de kotkoti (relieftatouage)-figuren hebben bepaalde beteekenissen. [Zie voor ornamenten $1 \mathrm{~Pa}$ en $1 \mathrm{~K}$.]

[De naam van een persoon of een voorwerp is veelal reeël verbonden met dien persoon of den geest van dat voorwerp; met het uitspreken van namen moet men voorzichtig zijn (§ 13)]. 
De Boschnegers kennen en gebruiken vele anansitori's (spinfabels, § 29) en ook vele odo's (spreekwoorden, zie C 23).

II. De mensch.

\section{§ 5. De akrá.}

Elke mensch heeft een akrá, dat is een soort hooger zelf of beschermgeest. N'ná, het Opperwezen, geeft den mensch zijn akra. Bij de geboorte is de akra reeds aanwezig; bij den dood verdwijnt ze naar het geestenrijk en manifesteert zich niet meer.

Gedurende den slaap is de akra buiten het lichaam, waardoor dit volkomen rust kan genieten. Droomen worden door andere geesten ingegeven. Zonder akra kan de mensch niet geregeld denken. Men mag nooit iemand laten schrikken, of bijv. een kind toesnauwen, want daardoor kan de akra weggaan. Iemand plotseling wekken, kan veroorzaken, dat zijn akra niet terugkeert en hij wegkwijnt, ziek wordt, of krankzinnig.

Een mensch heeft de plicht zijn akra te dienen en te vereeren, het haar zoo aangenaam mogelijk te maken en geregeld aan haar te offeren, waarvoor omgekeerd die mensch de onbegrensde bescherming van zijn akra geniet. Een Djoeka die een huis bouwt, biedt het met een toespraak zijn akra ten geschenke aan, in tegenwoordigheid van familie en vrienden.

De akra wordt toornig, als haar drager haar niet voldoende eert, als deze woordbreuk pleegt, bedriegt, een meisje in den steek laat, kleeding of huisraad verwaarloost, zijn prestige niet weet te bewaren, of als hij verzuimt geregeld aan de $a k r a$ te offeren; dit alles is ,,misi $a k r a$ ", tekortkoming jegens de akra. Een verstoorde akra kan zijn drager leed berokkenen en hem zelfs krankzinnig maken; als een man tegenspoed ondervindt, is het in negen van de tien gevallen, dat zijn akra verstoord is. „Men kan zoo iemand vergelijken met een boot zonder stuur in een hevigen storm", legde een bejaarde Djoeka mij eens uit.

Om zijn akra weder gunstig te stemmen, biedt de schuldige Djoeka de akra een rijk maal aan. Hij neemt voor minstens drie dagen zijn intrek in de kréihoso (\$ 55); de priester die aan de fragatiki (§ 55) voor hem komt bidden, en vrienden en bloedverwanten die de plechtigheid zullen bijwonen, blijven bij hem. Op de tafel in de kréihoso staat voor den eersten avond rum en wat droge versnaperingen. De 
volgende dag is de dag van het spijsoffer. Zijn bloedverwanten en zijn vrouw koken de spijs en brengen de gerechten op tafeltjes in de kréihoso. Weder wordt aan de fragatiki gebeden. De schuldige eet en tegenover hem staat een portie voor zijn akra, die verondersteld wordt met hem aan tafel te zitten. De akra geniet het astrale van zijn portie en daarna eten de familie en de vrienden het materieele van die portie op.

Gaat het na deze handeling den betrokkene weder goed, dan bewijst dit, dat zijn akra hem weer in genade heeft aangenomen. Houdt de regenspoed aan, of neemt ze toe, dan is het, dat de verstoordheid van de akra voortduurt, en er wordt nogmaals en nogmaals geofferd. Het komt voor, dat ook dit niet baat en dat het eindigt met dood of krankzinnigheid.

Verstoordheid van de akra kan nooit door een ander mensch veroorzaakt zijn, alleen door tekortkomingen van zijn drager. De Djoeka gelooft, dat de wisiman (booze toovenaar) instaat is alle kwaad over een ander te brengen, doch niet instaat is iemands akra tegen zijn drager op te stoken.

d. G. 1937 : Een man draagt om den hals een koord met een papa moni (kauri schelp); dit is een obia, die zorgt dat je akra no kan wai (niet kan weggaan). W. L. Loth 84 beschrijft hoe een man een amulet voor zijn zieke vrouw makt om haar akra terug te roepen; vgl. $1 \mathrm{H} 321$ Saramakkaners ak'a tetei.

BONNI (v. L.). Ik bracht eens aan Bajo, kapitein der Bonni's (foto Ve 318) aan den surinaamschen oever der Lawa, een jachtgeweer ten geschenke. Het geweer beviel hem en nadat hij het goed had bekeken, legde hij het dwars over zijn schoot en verzocht de omstanders dichterbij te komen. Hij zeide daarop ,a dia, mi akra, joe gon dia, teki ing" (het is hier, mijn akra, je geweer is hier. aanvaard het; vgl. $2 \mathrm{H} \mathrm{51)}$ en verzocht de omstanders, met handgeklap zijn akra te huldigen. Daarna plengde hij wat sterke drank op den grond voor zijn akra en vervolgens schonk hij aan alle aanwezigen wat sterke drank.

SAR De akála van het kind ontstaat als vanzelf, zooals het lichaam, en houdt op te bestaan bij den dood, gaat niet over naar een ander persoon (zie echter $\S 9$ ). De akala zetelt in het geheele lichaam, is je lichaamsgeest. Als je slaapt, dan is de akala buiten het lichaam en kan je in een droom iets openbaren.

Een sterke obiaman kan de akala van een slapende op afstand oproepen en als hij kwaad wil, die akala met een geweer dood- 
schieten; een goede obiaman kan de akala voor goede doeleinden oproepen. De obiaman ziet de akala als een gestalte.

Als je bang bent, als iets je laat schrikken, dan gaat de akala weg; je wordt ziek, ziet er bleek uit, hebt zware hoofdpijn en bindt daarvoor een doek om het hoofd. De akala moet teruggehaald worden door een kruidenbad. De Saramakkaners geven niet, gelijk de Stadsnegers, een feest voor de akala, wel voor de jorka.

Als het kind geboren is, dan deelen de ouders bier uit aan de menschen die komen om pret te maken en dit is een geschenk van het kind aan zijn akala (ncmseki, zie $\S 9$ ), opdat het kind op aarde altijd gelukkig zij.

De akala houdt bijv. van witte of rose kleur en u draagt een andere kleur: dan word je ziek. Of de akala houdt niet van iets, of houdt van goud, van zilver, van koper: je moet aan haar verlangen voldoen; wat je akala verlangt, wordt $\mathrm{u}$ in een droom geopenbaard. De akala geeft ook an, of men iets moet doen of nalaten; hij is je geweten. Als ik tegen den wil van mijn akala handel, dan laat ze mij ziek worden; wel zwaar ziek, doch de akala doodt mij niet, gelijk een jorka kan doen.

STAD De akra of kra is joe jeje, dat je draagt (Fo 50, Wu 100 ziel, geest $=j e j e)$; inplaats van ,mijn akra” zegt men ook wel , ,mi jeje”, ,mi séi” (Schu $101 \mathrm{SAR}$ ziel, geest $=$ she). De akra is de leidende geest van een mensch, zijn dagelijksche geleidegeest; roomsch katholieke Negers nemen aan, dat de akra de Engelbewaarder is.

Elke mensch heeft 2 akra's, een mannelijke en een vrouwelijke, die er zijn, zoodra het kind geboren is. Die akra's zijn geesten van den geboortedag. Is bijv. een kind op Zondag geboren, dan heeft het Kwassi tot mannelijken leidenden geest of akra, en Kwassibá tot vrouwelijken leidenden geest. Volgens een anderen zegsman, B. : elke mensch heeft een man-kra van den vader en een oeman-kra of sisa van de moeder (sisa, ook vermeld 1P 159; Ellis Ewe 15, Yoruba 133 noemt sisa een na den dood rondzwervende $k r a$.) Vóór de geboorte en na den dood bestaat die $a k r a$ niet $^{1}$ ).

Zegsman B. heeft zijn akra in zijn handen, terwijl anderen hun akra in het hoofd hebben (vgl. $2 \mathrm{H} 47,48$ ); de akra is niet in het hart. Als men inslaapt, gaat de akra wandelen; de akra gaat boven uit het hoofd en keert ook langs dien weg terug. Alles wat je droomt, is

1) De naam kasulu, 1P 159 (en Penard, De menschetende aanbidders der zonneslang, Paramaribo 1907, blz. 228), is een vergissing, zie De Periskoop 24 Maart 1928. 
wat de akra in het donker ziet en aan je overbrengt. Slapeloosheid is, dat de akra het lichaam niet wil verlaten. De akra kan voor een oogenblik van je weggaan, als je schrikt. Doch ook een kwaadwillige kan de akra weghalen met behulp van zijn eigen kwade winti $(\S 12)$; dit is wisi (§ 48) (MK IX. De kra verlaat den mensch gedurende den slaap door den mond. Daarom is het zoo schadelijk met den mond open te slapen. Bij het einde van den slaap keert zij terug, doch geheel vrijwillig. Daarom moet men iemand nooit plotseling wekken, doch bedaard).

$(2 \mathrm{H} 103$ vermeldt: It is thought that the souls of men, like the winti, may belong to the earth, to the water, to the air. - Is hier eigenlijk de djodjo, $\S 10$, bedoeld, die dikwijls met de akra dooreen gehaald wordt, zie $2 \mathrm{H} 44$ ?).

Als men zwak is, dan gaat men naar een loekoeman (§ 37). Men neemt een kommetje waarin een kippenei en plaatst dat op de plek waar de akra is (hand of hoofd); schudt het ei, dan is dit een teeken, dat de akra gekomen is. Men vraagt wat de akra verlangt, bijv. een halsketting of een kip, en als de akra ,ja" zegt, dan geeft ze dat te kennen doordien de betrokken persoon met het hoofd ,ja” knikt; (uitvoeriger 1P 159, 2H 46 vlg.).

De akra vindt het aangenaam, als haar drager zich wascht met lavendelwater of eau de cologne; men doet dit in een groote Indianen-prapi (schaal), kan er ook wat jenever, brandewijn en bier bijvoegen en rondom den schotel doet men bloemen. Het water mag slechts één maal dienen, wordt dan weggeworpen.

Als je de akra niet het offer geeft, dat zij verlangt (bijv. kip, eend, een ketting, een ring), dan kan zij je je gewone bezinning benemen, zoodat je als een dwaas rondloopt, gaat stelen, enz.

Men geeft nu en dan een feest om de eigen akra te eeren, en in het bijzonder, als die akra vertoornd is en verzoend moet worden. Ook de Negers die tot een kerk behooren, doen dit. Soms doen zij het bedekt, bijv. iemand geeft een verjaarsfeest; in werkelijkheid is dit een feest voor de akra. Als degene die het feest aan zijn akra geeft, bijv. op Zondag geboren is, dan moet dat feest plaats vinden op een Zondag en de aanzittenden moeten allen naamgenooten zijn, die ook op Zondag geboren zijn.

Het volgende heeft iemand bij een gegoede creolenfamilie (de overgrootmoeder der kinderen was een Negerin) te Paramaribo bijgewoond. De familie verhuisde. Vóór men het ledige huis verliet, sprak de grootmoeder tot alle kinderen, wier namen (ook die der 
kinderen welke reeds vooruit waren gegaan) ze opnoemde, zeggende, dat ze heengingen: ,gaan jullie mee, want wij verhuizen; niemand mag hier achterblijven; en tegen haar dochter, de moeder der kinderen: „Annie, laat ons gaan”. Annie antwoordde: ,ja ma, laat ons gaan, maar jij mag ook niet achterblijven, ma!' Klaarblijkelijk was dit het oude gebruik, ten doel hebbende te zorgen, dat de $k r a$ 's niet achterblijven. (Iets dergelyks, $2 \mathrm{H} 49-50,2 \mathrm{P} 18-19$ ).

\section{§ 6. Het dubbel.}

STAD Het komt voor, hoewel weinig, dat iemand zichzelf naast zich ziet loopen. v. L. kent personen in Paramaribo, die dit hebben; een dame, mej. K., is van schrik hiervan gestorven.

Waarschijnlijk doelt hierop 1P 161: „De kra vertoont zich soms aan zijn eigenaar als een zichtbaar evenbeeld en wordt dan dobroe geheeten. Dikwijls gedraagt zulk een dubbel zich zeer verkeerd en brengt daardoor zijn eigenaar in ongelegenheid". Ook Bex $\mathrm{V}$ : „er slaat een uur, waarop $K r a$ je aankondigt, dat de dood je bedreigt. Dan zie je iets om je zweven, je dubloe, je dubbele, je evenbeeld”.

\section{§ 7. De kraka.}

Een zichtbaar beeld van de akra, is de schaduw, die de Djoeka kraka noemt.

De akra van den eenen mensch is machtiger dan de akra van een ander. Wanneer nu de schaduw van een mensch met sterke akra strijkt over een mensch met zwakker akra, of zelfs over een lichaamsdeel van dezen, dan heeft deze kans ziek te worden, te verzwakken en in het ergste geval kan het zijn, dat de zwakkere akra de vlucht neemt. Ook voorwerpen, zooals een jachtgeweer, kapmes, bijl, kunnen hun goede eigenschappen verliezen, als de kraka van een ander er overheen gaat. Het hindert niet, als de schaduw van iemand ergens op valt, doch wel als de schaduw er overheen strijkt. [Ik stapte eens over het op den grond liggend geweer van een Djoeka; deze zeide, dat Djoeka's dat niet prettig vinden. d. G.].

Gesteld, dat een sterke wisiman aan een vijand een kinoto (oroekoekoe-slang, Lachesis atrox) of jakroeka (boschmeesterslang, Lachesis mutus) toezendt, en de betrokkene weet de slang te ontwijken, dan nog kan de akraka van de slang, de akraka van dien 
mensch bijten en de betrokkene sterft aan slangebeetverschijnselen.

Menschen die een ander kwaad willen doen, probeeren diens akra te vangen en dat kunnen ze doen door hem schijnbaar achteloos te volgen en als ze in zijn kraka gekomen zijn, de akra te vangen in een, tevoren in een kruidenbad ( $\$ 57$ ) gedrenkten doek, dien ze bij zich hebben. De boosdoener bewerkt thuis de gevangen akra; hoe dit geschiedt, is niet bekend; de wisiman verklapt dit geheim niet. Hij richt die akra erop af om den drager der akra bijv. tot een dief te maken of tot iemand die aan den drank verslaaft, of die de vrouwen van zijn vrienden verleidt; daarna wordt de akra losgelaten en treedt weder in zijn drager.

STAD De schaduw van een mensch is niet zijn akra. (MKIX De kra is heel wat anders dan de somra (WU 194 sombra, schaduw) of mikrá. Deze noemen wij ook sec. De kra is een andere geest, die, behalve de $s e c$, ons bijblijft).

\section{§ 8. De jorka.}

Elke mensch heeft een jórka; bij de geboorte is de jorka reeds aanwezig, doch men gebruikt het woord jorka slechts met betrekking tot het bovenzinnelijke dat van den persoon na den dood blijft voortbestaan. [3J 92 De jorka van een overleden persoon blijft al de karaktereigenschappen van dezen behouden].

Men maakt onderscheid tusschen takroe jorka's, gewone jorka's en Granjorka's. De takroe jorka's zijn de geesten van slechte menschen, die ook na hun dood hun booze daden blijven voortzetten. De gewone jorka's zijn de jorka's van goede menschen, die echter geen bijzondere verdiensten hebben. De Granjorka's zijn de geesten van afgestorvenen die groote daden verricht, of een heilig leven geleid hebben, of bijzonder deugdzaam waren. Men onderscheidt (1L 42) dezulken die Gado bresi (door God gezegend) zijn, d.z. zij die op aarde zulk een goed leven hebben geleid, dat zij na hun dood dicht bij de goden mogen wonen; hun gebeden aan de goden worden altijd verhoord. Van de anderen wordt gezegd $A$ de kroetoe na gado kondre (hij neemt deel aan de raadsvergaderingen der goden); dit zijn degenen die hun medemenschen tot zegen zijn geweest en aan het geluk en den vooruitgang van den stam hebben medegewerkt; na hun dood worden zij tot de raadsvergaderingen der goden toegelaten, ter beraadslaging over het lot der aardbewoners. Tot de eerste soort Granjorka's behooren zoowel vrouwen als mannen, tot de l.g. alleen mannen. Bij 
vele gelegenheden bidt men tot de Granjorka's, die dan pleitbezorgers bij de goden zijn.

[C 13-14 meldde : $\mathrm{Zij}$ gelooven, dat met den dood het bestaan van den mensch eindigt, doch dat de geest van den afgestorvene niet geheel verdwijnt maar nog langen tijd onder hen blijft. Ook gelooven zij aan ongelukkige geesten, die door een vroeger misdadig leven, rusteloos moeten ronddwalen, terwijl het leven op aarde der rustige geesten vrij van misdaden zou zijn geweest.

Belooning hier namaals voor goede daden nemen zij niet aan; misdaden worden echter, naar hunne meening, gestraft met rusteloos rondzwerven.

Zij zeggen dat die geesten alles weten wat er omgaat, en dat zij op hunne feesten er mede in aanraking kunnen komen, menigen wenk en opheldering ontvangen, en door verborgen teekens middelen tegen ziekten te weten komen, waaraan zij het volste vertrouwen hechten].

De jorka blijft bij het lijk, zoolang dit nog niet begraven is, of bij haar en nagels, en men kan dan vragen stellen aan de jorka, zie $\S \S 82,89$.

Het woord jorka is vermoedelijk van afrikaanschen oorsprong. [Een onderscheiding als tusschen de akra van den levende en de jorka van den doode, komt ook in Afrika voor, zie Ellis Ewe 15 vlg.; mijn onderstelling, dat jorka afkomstig zou zijn van het Kalienja-indiaansche woord joroka, geest (1G 51, Enc. 393, 2H 109) trek ik thans in. d. G.].

De jorka van een overledene kan in een familielid of vriend treden, zonder dat die het weet. Zoo iemand vertelt dan bijv. van plaatsen of streken waar hij nooit geweest is, doch waar de overledene is geweest. Het komt voor, dat jaren later die jorka zich nogmaals door den ander openbaart. Wat bij de Stadsnegers voorkomt, dat iemand zich meester kan maken van de jorka van een lijk, komt bij de Djoeka's niet voor. Wel kan men, en dit geschiedt veelvuldig, de hulp der Granjorka's inroepen met een offer aan de fragatiki. En zie voorts $\S \S 82-89$.

SAR Elke mensch heeft een eigen jorka; dier en plant hebben geen jorka. De jorka blijft na den dood op aarde zwerven en kan treden in de hersens van het achterhoofd van een levende. De jorka kan dan door diens mond spreken en profeteeren (,,die dingen komen soms uit; de duivel heeft ook zijn middelen" zeide mijn zegsman, die Christen was), bijv. ,over een paar jaren zal ik ziek worden”. Men zegt van zoo iemand ,a habi geesti". Zoo'n door een geest 
bewoonde moet men nooit op het achterhoofd krabben, want dan begint de jorka te praten bij monde van den persoon waarin ze is, en dat is niet gunstig. Misschien zal de jorka zich laten betalen omdat je hem bent lastig gevallen.

Als iemand gestorven is, dan nemen ze wat van zijn okselhaar en schaamhaar en wikkelen dat in een doek; dan is de jorka van den doode erbij en deze ondervraagt men wat de reden van het sterfgeval is. [3J 92, 4J 55 Zoolang een onderdeel van het lichaam aanwezig (niet begraven) is, zoolang vertoeft ook de geest daarin].

Als men iemand kwaad doet of doodt, dan komt de jorka van den beleedigde dit wreken, treedt in den schuldige, makt hem ziek (mijn zegsman meent dat dit hetzelfde is, wat de Stadsnegers toeschrijven aan een lebba of libba, § 24 (14)).

Als iemand ziek wordt, of zwak is, dan gaat zijn familie naar zoo'n door den jorka van een overledene vervulde; men schenkt sopi (sterke drank) uit over de aarde en zegt jorka, oe ko kai mei ko feng koe zvi (geest, wij komen u roepen om u bij ons te doen komen) en daarna: ,ik wil je vragen naar de oorzaak van deze ziekte en of de zieke zal sterven of leven”. De jorka antwoordt : ,zoo een fout heeft hij begaan; daarom wordt hij ziek". Dan vraagt men: „als wij u betalen, zal hij dan beter worden?” Als het antwoord luidt: „,ja, geef mij panji's (doek), of dram (sterke drank)”, dan zal de zieke beter worden. De zieke betaalt aan dengene dien hij kwaad heeft gedaan. Bijv. ik heb uw broer doodgeslagen; die broer komt als geest en ik moet goederen geven aan $\mathrm{u}$, want het was úw broeder. Die jorka zou ook mijn familie kunnen dooden; wij noemen dat meestal koenoe (zie $\S 14$ ). Als ik zoowel de zieke als de door een geest bewoonde, ben, dan moet men bij mij komen om den mij vervullenden geest op te roepen en te vragen of ik sterven zal of niet.

Als een jorka die niet mijn eigen jorka is, bij mij is, als ik sterf, dan gaat die op mijn broer of nicht over; er zijn menschen die drie jorka's hebben.

Datgene wat de bij de trom dansenden vervult, is nooit een jorka: een jorka danst niet, is alleen een onrust wekkende ziel.

Zie voorts Sta 262.

STAD Elke mensch heeft een eigen jorká; tapir en hert hebben een jorka, de overige dieren niet. De jorka van een mensch was er niet voor de geboorte, doch blijft na den dood eeuwig in verband met de familie (zie ook $2 \mathrm{H}$ 113). [Volgens Bex XVII moet men een lijk 
niet aanraken, vooral het hoofd niet, noch den naam van den overledene uitspreken of naar het lijk wijzen, want daardoor zou de jorka in je kunnen varen].

Als iemand slecht heeft geleefd, kan zijn jorka niet tot rust komen, verstoort de menschen, treedt in vleermuizen of nachtuilen op of loopt op straat en valt iemand aan.

De jorka van een doode zal uit zichzelf niemand kwaad doen, doch een wintiman ( $\$ 37$ ) kan haar nemen, betalen, aanzetten om kwaad te doen; zoo kan bijv. je eigen vader je dooden. De wisiman (booze wintiman) gaat naar een graf, graaft het lijk op of komt er met dranken om de jorka op te roepen, neemt de jorka mede en zendt die naar iemand dien hij ziek wil maken, hetzij uit persoonlijke wraak, hetzij omdat iemand er hem voor betaalt. Hij doet bijv. de jorka in een flesch, stopt dien in den grond en wie er over stapt, krijgt de jorka in zich. De wisiman kan ook iets in je spijs of drank mengen en zoo de jorka in je brengen. Er zijn enkele menschen (vooral vroeger waren die er), die, als iemand sterft, weten hoe ze iets bij het graf moeten zetten en dan kan niemand de jorka van den doode bemachtigen om kwaad te doen.

De jorka van mijn overleden moeder beschermt mij; doch als ik bijv. slecht ben tegen mijn zuster, dan laat mijn moeder's jorka mij ziek worden.

Wie een tapir doodschiet, moet een soesá-dans ( $§ 53)$ geven. Men kookt dan den kop, eet dien tezamen en maakt wat pret. Als je dat niet doet, krijg je nooit meer gelegenheid een tapir te schieten, want de jorka jaagt dien weg. Zie ook Bex I, XVII en $2 \mathrm{H} 10-12$ (manati).

Er zijn menschen die kruiden hebben als opo (amulet), doch er is niet genoeg kracht bij; dan voegen ze er een jorka bij om kracht te geven. Dit geschiedt o.m. als een man een vrouw wil hebben.

Een doode doet men schoone kleeren aan; de gedragen kleeren legt men buiten, achter het huis, en den dag na de begrafenis wascht men die kleeren. In dien tusschentijd kan een slechte loekoeman (§ 37) bij die kleeren komen en de jorka eruit nemen en gebruiken om menschen lastig te vallen. De goede lockocman weet de jorka tot rust te brengen met een kruidenbad waarmede men je wascht.

Een Stadsarbeider, W., die met van Lier in 1911 an de Goninimonding was, lag ziek en bekende: ,ik heb een ampoekoe ( $\$ 24$ (2)), die zich uit liefde bij mij als zijn hási (paard, drager) heeft gevestigd, een bakroe (\$ 49) die mij beschermt tegen aanvallen van anderen en 
door mijn vader in mij geplant is, en een jorka, die, toen ik nog jong was, door mijn vader (een obiaman van de Para) uit het graf van een afgestorvene is gehaald en in mij is gezet, welke jorka voor mij werkt, zoodat ik werkende, zelf niet bemerk dat ik werk, niet moe word. Deze W. stierf en zijn lijk werd begraven op de begraafplaats aan den Gonini-mond. Geruime tijd later betrapte v. L. een Stadsneger die 's middags 12 uur (vgl. $\S 57$ slot en $1 \mathrm{P} 158$ ) op die begraafplaats bezig was om de jorka van W. te vermeesteren, teneinde die in een ander te zetten (de in W. gezette jorka verdween bij diens dood; hier ging het om de jorka van W. zelf).

\section{§ 9. Ninseki en reincarnatie.}

De ninseki (naamgenoot) van den mensch is datgene wat zich reincarneert.

Elk Djoeka-kind wordt geboren met den geest van zijn ninseki. De ninseki kan een der voorouders uit dezelfde familie zijn, doch ook iemand niet uit de familie; zelfs iemand van een ander ras, wat echter niet veel voorkomt. Echter kan nooit een vrouw als ninseki terug komen in een mannelijk kind, of een man in een vrouwelijk kind.

De ninseki blijft na den dood voortbestaan en komt weder in een ander kind terug; het kan heel lang duren, het kan ook kort zijn. In dien tusschentijd is de ninseki in het geestenrijk; echter is de ninseki die in een kind is getreden, toch ook nog in het geestenrijk. Oséisi (Granman der Djoeka's, overleden 1915) bijv. is in een achterneefje te Drietabbetje getreden, doch blijft in het geestenrijk voortbestaan en wordt aan de fragatiki ( $\$ 55)$ aanbeden, en die aanbidding heeft niets te maken met dat kind.

Het is de plicht der ouders om zoo spoedig mogelijk na de geboorte van een kind, er zich van te vergewissen wie de ninseki is, van welken afgestorvene de geest is, die in het kind is gevaren. Men moet namelijk, opdat het kind gezond opgroeie, op gezette tijden offeren aan den ninseki en daarvoor moet men diens naam kennnen. Zou men dit offeren verzuimen, dan kan het gevolg zijn, dat het kind ziek wordt of sterft. Wie de ninseki is, wordt óf door een obiaman geopenbaard, óf door het orakel ( $\$ 54)$, een enkele keer ook wel in een droom aan een bloedverwant. Zie verder $\S 73$.

De eigenschappen van den ninseki, goede zoowel als slechte, zijn ook de eigenschappen van het kind. Op Drietabbetje werd een kind 
geboren en later bleek het den ouders, dat zijn ninseki een Stadsneger was, een balatableeder die vriendelijk voor de ouders was geweest en die te Drietabbetje begraven was. De ouders zeiden: „dat kind heeft bakra-manieren" (bakra $=$ Blanke, doch ook halfbloed of Neger uit de stad of van elders in West-Indië).

SAR Stel ik heb $u$ iets goed gedaan; $u$ gaat dood en als ik een kind moet krijgen, dan gaat uw geest, uw persoon, over in mijn vrouw (,zooals de Heilige Geest in Maria”, zegt mijn zegsman); $u$ is de nemseki van dat kind. Wij herkennen dat $\mathrm{u}$ het is, aan een teeken; bijv. $u$ had zich vroeger gesneden en aan het kind is dat litteeken te zien.

Wie het zal zijn, die aldus in het kind zal optreden, openbaart zich tijdens de zwangerschap aan den vader of aan de moeder, die dezen persoon droomt. Bijv. ik droom dat u mij een houwer (kapmes) hebt gegeven; dan weet ik, dat een jongen geboren zal worden. Droomt mijn vrouw, dat $\mathrm{u}$ haar een potje of kom geeft, dan weet ze, dat een meisje geboren zal worden. Doch ook mijn vrouw kan van een houwer droomen. En na uw dood kan uw geest evengoed in een meisje als in een jongen treden.

Man kan terugkeeren als man of als vrouw; vrouw kan terugkeeren als vrouw of als man. Een Boschneger kan zeggen: ,,als ik sterf, dan zal ik niet een man worden, maar een vrouw; een vrouw zegt evenzoo: ,ik zal niet een vrouw worden, maar een man”.

Wat men in de stad djodo en akra noemt, is dezelfde geest; de Saramakkaners noemen dit Akala en gebruiken den naam djodjo (§ 10) niet. Mijn tegenwoordige geest is mijn akala en tegelijk de nemseki van iemand die vroeger leefde en toen diens akala was. Als iemand sterft, dan blijft deze geest rondzwerven, treedt bijv. na 1 of 2 jaren in een kind en blijft gedurende het geheele leven van dien nieuwen mensch in hem. De Stadsnegers gelooven dat ook (beweert mijn zegsman). Men zegt van dien vroegeren mensch „a kong anási na mi", hij is mijn nemseki geworden. Zijn anási of nemseki is overgegaan, zijn jorka is afzonderlijk gebleven.

De nemscki kan ook zijn de geest van iemand die tot een ander ras behoorde of in een ander werelddeel leefde.

Als iemand altijd ongelukkig op aarde leefde, verbergt hij zich, openbaart zich niet in een droom en alleen aan een teeken aan het kind is te zien, dat hij het is, die in dit kind is getreden.

De ouders weten altijd wie de nemseki van hun kind is. Eénzelfde nemseki kan in 2, 3 tot 4 menschen wonen, die 
allen een verschillenden naam hebben; het gaat hier niet om gelijkheid van naam.

Een menschengeest treedt nooit in een dier. Er is echter wel iets van soortgelijken aard bij de dieren. Ik schiet bijv. een konijn (Dasyprocta Aguti) en snijd in de ooren. Later schiet ik een ander konijn en zie datzelfde merk weder.

STAD De akra van een gestorvene komt later terug in een andere buik en wordt opnieuw geboren. Wie arm was kan in het volgende leven rijk zijn; men kan ook in een ander ras wedergeboren worden. Alle menschen hebben vroeger al geleefd, doch nooit als dier. Alle Negers, Stadsnegers zoowel als Boschnegers, gelooven in deze wedergeboorte. Een andere zegsman zegt: Nemseki is, wie op denzelfden weekdag geboren is $(\S 5)$, of wie denzelfden gewonen (doop-)naam heeft; hiermede wordt niet gedoeld op reincarnatie.

Het komt voor, dat een kind geboren wordt en men ziet aan een merkteeken, dat het een vader, neef of tante is, die herboren wordt. Sommigen maken bij een gestorven kind een gaatje in het oor, als merkteeken. Uitsluitend een familielid wordt op deze wijze herboren. Als het niet een dergelijke reïncarnatie is, dan rekent men, dat de mensch uit God komt.

Zie nog: Stn III/1/301 Alle negerslaven hebben het geloof, dat wanneer zij als slaven terechtgesteld worden, ze naar hun vaderland (Guinea) gaan en daar hun volle vrijheid herkrijgen. (Labat, Nieuwe reizen naar de Franse eilanden van America, Amsterdam 1725, I 158-159 de Negers uit Mina in Afrika plegen licht zelfmoord ,zig inbeeldende, dat ze na haar dood in hare landen weêr zullen verryzen; welke zotte inbeelding in haar zo gewortelt is, dat men ze hen onmogelijk uit 't hooft praaten kan"). Stn III/1/184 De Negers gelooven aan eene gedaanteverwisseling van de ziel van een afgestorvene, hetzij in een nieuwgeboren kind, of in een dier. Stn II/2/ 283 Overigens gelooven deze vrije Negers (Saramakkaners), dat hun ziel niet sterft, maar in een ander lichaam voortleeft, dus in een soort zielsverhuizing. Teenstra II 172 Velen hunner gelooven, dat de zielen der afgestorvenen in de jonge kinderen wederkeeren, vermeenend tevens, dat dezelve hen altijd en overal omgeven en kennis van hun doen en laten hebben.

Enc. vermeldt niets over het reincarnatie-geloof; van Lier heeft het opnieuw ontdekt (5L, 6L). 


\section{$\S 10$ De gado (djodjo).}

Hetgeen de Stadsnegers djodjo of widjodjo noemen, en de Boschnegers gado (god), is het volgende:

Bij allen heerscht het begrip, dat er op bepaalde plekken geesten wonen: in het bosch bij kreekmondingen, onder groote boomen (vooral de kankantri, Ceyba), bij groote rotssteenen in het woud, enz.; in de stad op erven, bij een vruchtboom of in een waterput, ook wel aan de negerpoort; op de plantages bij de sluis, bij de groote lostrenzen, aan de landingsplaatsen, enz. Een dergelijke geest nu, kan uit genegenheid voor een familie bij de geboorte van een kind in dat kind (of in de nog ongeboren vrucht) varen en treedt dan verder op als een soort beschermgeest. Vóór de geboorte van het kind vindt men door raadplegen van den heiligen bundel (§54) uit, waar de gado zich ophoudt en gaat naar die plaats om aan den gado te offeren. Wederom wordt geofferd na de geboorte en het individu doet het voorts zijn leven lang op gezette tijden en des te meer bij ziekte of andere onheilen.

Men moet echter voorzichtig zijn met deze beschermgeesten; ze zijn lichtgeraakt en wreken de minste beleediging die hun wordt aangedaan. Het individu kan ziek worden, tegenspoed hebben in alles wat hij onderneemt, en nog meer, doordien zijn gado (djodjo) verstoord is. Deze geest kan bijv. verlangen dat zijn drager een bepaalde kleur draagt, of kan verstoord zijn omdat zijn drager woont op een plaats die dien geest niet aanstaat.

Eigenaardig is, dat de gado ook verstoord raakt, wanneer het individu door anderen beleedigd of slecht behandeld wordt. Als bijv. iemand mij niet groet of mij hoont of op een andere wijze tekort doet, dan zal de verstoordheid van mijn gado daarover, zich als ziekte van mij, openbaren. Kiemboto, een meisje van het dorp Pauwi, is eraan gestorven. Op het dorp was zij niet gelust, er werd veel kwaad van haar gesproken; haar stiefmoeder kon het nooit met haar vinden, enz. Toen het lijk werd rondgedragen $(\S 82)$, verklaarde dit, dat Kiemboto was weggehaald door haar gado, die den smaad en de hoon, haar telkens aangedaan, niet langer verdragen kon.

STAD Ieder mensch heeft 2 djodjo's, een man en een vrouw, mama en papa. De djodjo is iets dat op een bepaalde plaats is, bij een boom, een put, den mond van een kreek. De djodjo blijft daar, doch hij heeft het kind gebracht aan de moeder. Bijv. de moeder droomt vóór ze zwanger is, dat ze gaat naar een put of kreek en 
daar met den hengel een visch vangt; of dat ze onder een boom een ei vindt. Dat is de djodjo, die het kind aankondigt aan de vrouw. Soms is er ook geen droom.

De man-djodjo en de vrouw-djodjo hebben niets te maken met de vleeschelijke moeder van het kind; zij kunnen op geheel verschillende plaatsen wonen en zijn niet een echtpaar. De djodjo kent mijn gewone naam niet, heeft alleen met mijn dagnaam $(\S 5)$ te maken. Overigens echter heeft de djodjo niets te maken met de akra.

De djodjo is eigenlijk een winti, hetzij Indiaan ( $\$ 22)$, hetzij Kromanti ( $\$ 24(13))$, enz. De djodjo geeft eigenschappen aan het kind, doch komt nooit, als het kind volwassen is geworden, op de wijze van een winti over den persoon (bezetenheid); wel kan de djodjo-geest van den een als winti over een ander komen.

Als er winti gedanst wordt en een winti wil over een mensch komen, en de djodjo wil dat niet, dan belet de djodjo ( $\$ 37$ de $a k r a)$ het. Als het noodig is, kan de djodjo zijn beschermeling bewaken. Bijv. je bent ergens gegaan en er zou je iets overkomen, doch in het geheim heeft je djodjo dien boozen geest van je afgewend (zie ook 1H 211-212).

Het komt voor, dat een kind ziek wordt en de deskundigen vorschen uit, dat de djodjo van het kind een belooning wil hebben, bijv. als die djodjo een Indiaan-winti is: bakoven, bananen, kassave, cognac, sigaren, kleedingstukken. Dat wordt bij elkaar gebracht en in een kleine mand gedaan, die men neerzet op de plaats waar de djodjo woont. Het kind wordt op die plaats gewasschen; is daar water, dan met dat water; anders neemt men water mee. Daarmede is de djodjo beloond. Woont bijv. de familie te Paramaribo, doch de djodjo van het kind ver in het binnenland aan den Gonini-mond, dan zou men daarheen moeten gaan om de djodjo te beloonen, doch kan niet gaan. Men doet nu de belooning in een klein speelgoedscheepje met een vlag of papiertje erop ,dit is voor den Goninimond" en laat dat scheepje te Paramaribo te water (Bex VI: door de rivieren staan we in verband met de mama's in de bosschen en tot over zee). Desgelijks als de djodjo woont bij een boom dien men niet bereiken kan, legt men de belooning in het bosch neer.

MK XX Een djodjo-pikien is een kind dat door den geest in den moederschoot is gemerkt, bijv. bij het oor; krijgt zoo'n kind winti, dan kan het de winti-mama, den geest die hem alsdan vervult, noemen.

Volgens een zegsman, zendt de Gronmama (\$22) de djodjo of 
séi (§ 5); volgens Bex VI wordt de djodjo ook mama van de kra genoemd (mama is, naar het schijnt, een algemeene naam voor den natuurgeest van een plek of van een groep individuën).

\section{§ 11. Gado der tweelingen.}

Er bestaat een gado die uitsluitend tweelingen ( $\$ 33$ ) beschermt. Wordt van een tweeling er een ziek, dan moet uitgezocht worden, of diens persoonlijke god of de tweelinggod verstoord is, en dienovereenkomstig wordt geofferd. Dat geldt niet alleen voor kinderen; ik heb het meegemaakt, dat de heilige bundel aan een grijsaard die vele tegenslagen had, als de oorzaak aanwees, dat zijn tweelinggado verstoord was; de oude man haastte zich toen, aan dezen te offeren.

\section{§12. Gado (winti).}

Een mensch kan met een der in $\S 10$ bedoelde lagere goden of natuurgeesten ook op andere wijze verbonden zijn, dan aldaar is beschreven. N.1. zoo, dat zoo'n geest nu en dan zijn drager (hasi= paard) geheel vervult; deze verkeert dan in een toestand van bezetenheid. Zie verder $\S \S 36,37$.

\section{§ 13. Kina (treef).}

Kina beduidt ongeveer: door hoogere machten verboden handeling. Er zijn algemeene, groeps- en persoonlijke kina's.

Een algemeene kina, die de gansche stam raakt, is bijv. het verbod van vloeken, waardoor men tegen Grantata zou handelen $\S 41$ ). Een voor allen geldende kina is ook, dat de gado van een plek, niet wenscht dat men zijn naam uitspreekt; op de rivier, in of nabij een val, zal een Boschneger dan ook nooit den naam van dien val noemen ( $\$ \$ 4,23$ en zie Ve $327,1 \mathrm{G} 55,3 \mathrm{~J} 91$ ). En in een streek mag men op een bepaalden dag, de kinadéi, niet werken ( $\$ 25)$.

Boasi-kina noemt men een kina, op welker overtreding de straf van melaatsheid (boasi) staat. In de eerste plaats is er de boasi-kina die men erft in de vaderlijke lijn (soms kent men den vader, of althans diens kina, niet, en kan de kina niet in acht nemen). Voorts is er de lo-kina die men erft in de moederlijke lijn, welke verbiedt het vleesch van het totemdier der lo te eten. Voor degenen die als tweeling geboren zijn, is boasi-kina, het eten van het vleesch van de sapakara-hagedis, en van alle apenvleesch, den baboen (brulaap) al-

D1. 99. 
leen uitgezonderd, omdat deze de kenmerken van den aap: intelligentie en vlugheid, mist, en daarom niet als aap geldt. Tweelingen hebben nog meer kina's, bijv. het verbod van de vruchten van kruipof slingerplanten te eten (pompoen, meloen, markoesa enz.).

Elk heeft voorts een kina van den gado dien de stadsnegers djodjo noemen, en wie een gado heeft door wien hij bezeten kan worden, heeft ook van dien gado een kina.

Overtreding van de kina kan geneutraliseerd worden, door dadelijk na de overtreding de pot waarin de verboden spijs bereid was, van onderen te likken, of met middelen uit het plantenrijk, bijv. sangrafoe (§ 58).

Het begrip kina wordt ook figuurlijk gebruikt. Een man heeft bijv. gereedschap van een ander geleend en niet op zijn plaats teruggelegd. De ander geeft zijn ongenoegen te kennen door te zeggen „na mi kina”, d.w.z. een dergelijke nalatigheid is mijn treef, die duld ik niet. Ook in de stad, en dat niet alleen bij Negers, bezigt men op een dergelijke figuurlijke wijze het woord ,treef”. [Vgl. Duitsch „,ich verbitte mich”.] Zie voorts § 39 moela.

SAR De kina (Schu 107, 1H tchina) is veelal tata (vader) kina, komende uit de vadersfamilie, doch er is ook kina, komende van je nemseki, en voorts is er (1H 310, 318-319) kina van de obia (§59) die de betrokkene draagt.

STAD Treef komt van je mannelijke of/en van je vrouwelijke djodjo. Bovendien is er een vaste treef, die je van je vleeschelijken vader krijgt, niet van je moeder. Dagboek d.G. 1903. Cadel kermt, dat hij geen eten heeft. Rijst alleen is hem te min en onze hertenhâché is ,treef” voor hem. .... Albert schoot een vrij groot hert, 't welk Aken niet in zijn korjaal (boot) wilde laden, omdat het zijn treef is (iets dergelijks Bakhuis 120).

Zie voorts Lampe, Benjamins Treef en $2 \mathrm{H} 73$ en over vader-kina, 5H 719 en in Afrika Pechuël-Loesche 298 en 465.

\section{§ 14. Mekoenoe (koenoe).}

Mekoenoe of koenoe is het noodlot of de vloek die over een familie of lo hangt. De mekoenoe brengt krankzinnigheid, zuigelingensterfte, twist en oneenigheid, vijandschap of verkoeling tusschen familieleden of vrienden, afspringen van huwelijksverbintenissen, misoogst, tegenspoed bij de jacht, zinken van booten in de watervallen; of zij laat de leden van een familie stelen, overspel plegen, twist met andere $l o$ 's zoeken, enz. 
Een mekoenoe ontstaat vooral door pikadoe, d.i. bloedschande, doch ook door woordbreuk in een gewichtige overeenkomst, schenden van beloften, bedrog, ontrouw, valsche getuigenis, uitspreken van een onrechtvaardig vonnis, enz. De mekoenoe, hoewel veelal veroorzaakt door den misslag van een enkelen persoon, hangt over diens geheele familie of $l o$ en het heet, dat ze eeuwig voortduurt, doch sommigen meenen, dat ze afloopt, als de straf gevallen is.

Aan de koenoe wordt niet geofferd, doch des te meer moet zij aanbeden worden.

PARAMAKKANERS d.G. 1937. Men zegt, dat over het dorp Langa Tabbetje een koenoe ligt, doordien indertijd de Granman Apensa en een ander in het bosch een mensch gedood hebben.

SAR 1H 62-79, 3J 132-137 en 4J 51 vlg.

$\mathrm{STAD} 2 \mathrm{H} 69$. Wu 48 bloedgeld = mekoenoe-moni, bloedschuld $=$ mekoenoe.

\section{$\S 15$. Fiofio.}

Fiofio is een toestand, die ontstaat tusschen vrienden of bloedverwanten waar het gevolg van kan zijn ziekte, tegenslag, zelfs dood.

Voorbeeld: de vrouwen van twee broers krijgen ruzie over de kinderen. De eene broer spreekt den andere daarover aan, doch men laat het erbij en schept de zaak niet uit de wereld, en daardoor ontstaat tusschen de twee gezinnen fiofio. Wordt nu in een dier gezinnen iemand door een sipari (rog) gestoken, of raakt een huis in brand, of wordt een kind ziek, dan acht men dit het gevolg van de fiofio. $\mathrm{Om}$ dit te voorkomen, hadden degenen die onmin met elkaar hadden, samen aan de fragatiki een offer moeten plengen en voor het aangezicht van de Granjorka's terugnemen wat ze over en weer gezegd hebben, biddende dat er geen fiofio-gevolgen van ontstaan mogen. Zoolang dit niet gebeurd is, is er een reeks rampen te wachten en veelal zullen de betrokkenen, als het eerste ongeluk gebeurd is, zich haasten het alsnog in orde te maken.

$\mathrm{Zij}$ die in fiofio gelooven, zweren bij kris en kras, dat bij het overlijden van iemand als gevolg van fiofio, terwijl de laatste adem gegeven wordt, de fiofio-geest door de traankanalen naar buiten treedt, in de gedaante van het insect fiofio, dat een huis- of boschwants is.

SAR Als wij ruzie krijgen en ik zeg , ik wil dit potlood niet meer gebruiken" en ik gebruik het toch, dan wordt mijn akala boos en maakt mij ziek: „a kisi fiofio”. Dan maak je een kruidenwater (§ 
57), blaast erover en zegt ,ik moet niet ziek worden”. Zie ook $1 \mathrm{H} 148-150$.

STAD (van Lier) Het fiofio-begrip heerscht bij den Stadsneger even sterk, of nog sterker, dan bij den Djoeka. Een kindermeisje dat ontslagen wordt en aan wie door mevrouw onvriendelijke woorden zijn toegevoegd, waarop zij boos heeft geantwoord, zal, voor ze het huis verlaat, zich nog tijdig bedenken en afscheid van de kinderen nemen, omdat zij vreest, dat er anders fiofio ontstaat. Immers, de kinderen die aan haar gewend waren, mochten haar eens op straat ontmoeten, naar haar toeloopen, met haar spelen of haar aanraken; dat zou onmiddellijk fiofio tot gevolg kunnen hebben.

Geen fiofio dreigt, als de betrokkenen in ruzie blijven, doch wel als ze weder vriendelijk met elkaar worden, zonder dat de ruzie is uitgemaakt.

\section{§ 16. Moejèmboe.}

Moejemboe beduidt sensitief, intuitief voelend, ook: een voorgevoel hebben, zoowel bij Djoeka's als bij Stadsnegers. Voorbeeld: toen ik (v.L.) een voorgevoel had, dat Ds. Hoekstra overleden was, zeide ik tot een Djoeka: ,,mi moejèmboe náki mi dati wan gran patri foe mi kierki didde" (mijn gevoel slaat mij dat een groote priester van mijn kerk dood is).

\section{De goden en geesten.}

\section{$\S 17$. Nana of Masra Gado (Heere God).}

De Djoeka gelooft in een Opperwezen, Naná of N'ná geheeten; ook de Bonni's noemen het Opperwezen Nana. [Volgens 1H 29, 153 bezigen Saramakkaners het woord Nana om de voorouders uit Afrika aan te duiden; in Afrika is (Ellis Tshi 24) Nana een eeretitel met de beteekenis van ,grootvader"; het Opperwezen noemen de Saramakkaners Gran Gado, zie 3J 83, 84].

Deze opperste God is zoo hoog verheven boven de menschheid, dat $\mathrm{Hij}$ niet anders dan door de tusschengoden gediend kan worden; men heeft geen offerpaal voor Nana. De andere goden vermogen niets buiten den wil van Nana; zij zijn feilbaar en in hun besluiten brengt Nana vaak wijziging. Nana geeft den menschen hun akra's.

Als men aan een Djoeka bijv. vraagt ,zullen wij morgen daar aankomen?" en hij antwoordt ,ja”, dan voegt hij erachter ,,als God het 
wil", d.i, in deftigen stijl efi Nana gi, minder deftig efi Gadoe wani. [Dit doet al denken aan christelijke begrippen. Bij de Stadsnegers zijn, v.z.v. mij bekend, de christelijke goddelijke personen geheel in de plaats getreden van de afrikaansche hooge goden. d. G.].

\section{§18. Kediampon.}

Als een Boschneger door een gado bezeten is ( $\S 36)$, dan bidt de gado door den mond van zijn drager tot de Oppermacht Ananá Kediampo, God in den Hemel. Het oude Kromanti gebed van den Granman en opperpriester Bambi ving aan met Kedi amah, Kedi ampon, Heer der Hemelen en der Aarde (1L 10; volgens Sp. 39 Kobjanpoo $=$ het Opperwezen).

[Evenzoo begint een Saramakkaner gebed met Kediamo, Kediampon, waarmede de god van den hemel bedoeld wordt $(1 \mathrm{H} \mathrm{12,} 26$, 46). Volgens Saramakkaners gaf de hemelgod den mensch de obia

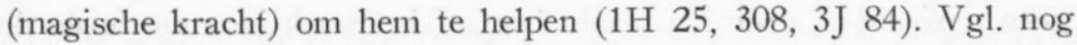
Ellis Tshi 24, Yoruba 36: Nyankupon, Tyoduampon, namen van den hemelgod, Pechuël-Loesche, Bennett Nsambi Mpungu, het Opperwezen en Enc. 391, 773 Jan Compaan, naam van het Opperwezen].

\section{$\S$ 19. Gwangwella of Grantatá (grootvader).}

Gwangwella, veelal Grantatá genoemd, om te vermijden dat men den eigenlijken naam uitspreekt, is een ongehuwde mannelijke, of een bovengeslachtelijke god en een der beide gran-gado's (oppergoden). Alleen Nana is nog hooger.

De overlevering wil, dat Grantata uit Afrika naar Suriname werd gebracht door een priester, ingewijd in de geheimenissen van diens dienst. Deze priester leidde zijn mannelijke nakomelingen die er aanleg voor hadden, op tot dien dienst. Toen aan het einde van lonten (of lontem, wegloop-tijd) de ordening naar $l o$ 's tot stand kwam, kwamen de priesters van Grantata in de Otter-lo, de lo waaruit de Granmans gekozen worden, en sedert kunnen alleen mannelijke leden van den onderstam der Otterlo's, priester van Grantata zijn, met den Granman als opperpriester. Van dit samengaan der beide functies is men, door den loop der omstandigheden, na den dood van Oséisi, afgeweken $(\S 1)$.

De opo-ningre ( $\S 1)$ achten zich de bijzondere dienaars van Gwangwella. De tempel van Grwangwella staat te Drietabbetje: vroeger, toen de Granman, die opperpriester is, op Pokéti woonde, was daar de tempel van Grvangwella. Aan Grantata danken de 
Djoeka's de instandhouding van hun stam, hun groote saamhorigheid; hij leidde hen in ,lontem". [Zie nader 2J].

De practische godsdienst van den Djoeka berust eigenlijk op de leer van Grantata. Die leer is er in de eerste plaats op gericht, den wisiman ( $(48)$ te bestrijden. Voorts mag men geen verwenschingen uitspreken, noch tegen zichzelf, noch tegen anderen ( $\$ 41)$. Woordbreuk of valsche eed zijn eveneens doodzonden, zoo ook bloedschande (pikado). Men moet vergevensgezind zijn, geen valsche getuigenis afleggen, geen afgunst koesteren, enz. Grvangwella is ook de god der gerechtigheid, die het kwaad streng straft, maar ook het goede beloont. Er is geen misdrijf, hoe gering ook, dat Grantata door de vingers ziet, geen goede daad, die niet door Grantata beloond wordt $^{1}$ ).

Elke jonge man of vrouw moet den eed aan Grantata zweren. Daarmede geeft de betrokkene niet alleen het bewijs, dat hij of zij geen wisiman is, doch het maakt hem of haar ook immuun tegen de aanvallen van een wisiman. Door dien eed is hij of zij in het stamverband opgenomen.

De ceremonie vindt plaats te Drietabbetje. Bij de hoofd-fragatiki stellen de Granman, die opperpriester is, en eenige voorname priesters, zich op. Grantata, d.w.z. de heilige bundel van dezen god. wordt uit zijn tempel gedragen en op twee mikken vlak bij de fragatiki geplaatst. De Granman richt nu het woord tot de menigte, wijzende op het gewicht van deze handeling, en vooral een ieder eraan herinnerende, dat wie onrein van hart is en toch driengi sweri (eed drinkt), aan de kwade gevolgen daarvan niet zal ontkomen. Een der priesters offert aan de Granjorka's ( $\$ 8)$, hun zegen vragende voor de plechtigheid, waarop de menigte bij de bede ,tjee Granjorka oen teki na begi"' (ach groote geesten, verhoort dit gebed) met zacht handgeklap instemt. Een priester houdt een kalebasschaal waarin een mengsel van kruiden en water met pimba, tevoren door hem bereid, en nu wacht men af. Doodsche stilte; niemand komt naar voren, geen wil de eerste zijn. Dan roept de priester een der candidaten bij den naam. Deze komt naar voren en hij of zij doopt de twee voorste vingers van de rechterhand in het mengsel en likt ze af, onder het uitspreken der formule ,ifi mi habi wisi mi moe dede" (als ik toovenarij heb, moet ik sterven) d.w.z. dan zal deze drank mij doen sterven. Met wisi is in dit geval niet alleen bedoeld giftmengerij of

1) Van Lier meldt, dat 1L 71 regel 20 v.b. en 72 regel 1 v.b. de namen Gwangwella en Gedéwsoe verwisseld moeten worden. 
booze toovenarij waarmede men iemand naar het leven staat of benadeelt, maar ook iemand een kwaad hart toedragen of afgunstig op hem zijn ${ }^{1}$ ).

Bij de betrokkenen heerscht een blijde feeststemming en zij verschijnen in feestkleeding. $\mathrm{Na}$ afloop worden zij door vrienden en kennissen gelukgewenscht, terwijl de oudjes hun nog een zedepreek medegeven voor het leven.

(Ook menschen die niet tot den stam der Djoeka's behooren, Boschnegers of anderen, kunnen desgewenscht tot den eed aan Gwangwella worden toegelaten. Immers is de bedoeling van deze driengi sweri niet alleen om ernstig getuigenis af te leggen, dat men de leer van Grantata aanhangt, doch vooral, dat men geen wisiman is; door deze handeling verkrijgt men ook de bescherming van Grantata, in de eerste plaats tegen wisi).

Om de drie jaar moet men den eed vernieuwen. Sedert Oséisi in 1915 is gestorven, is dit verslapt.

Ziekteëpidemie of misoogst wijt men aan verwaarloozing van de leer van Grantata. Dan wordt de stam bij elkaar getrommeld en in zoo'n tijd is het een voortdurend komen en gaan op Drietabbetje. $\mathrm{Z}_{\mathrm{ij}}$ die in de vrachtvaort zijn, moeten weer naar huis komen; het duurt soms weken eer iedereen op Drietabbetje is aangekomen.

Wie komt, krijgt gelegenheid den zuiveringseed af te leggen; liefst laat men grootere groepen tezamen dit doen. Wie wegblijft zonder gegronde reden, staat bloot aan de verdenking een wisiman te zijn. Wie tegen zijn wil niet in staat was te komen, kan op zijn dorp, bijgestaan door een priester, bij de fragatiki aldaar, de Granjorka's tot getuige nemen, dat hij geen wisi heeft.

Vroeger werd elk jaar voor het geheele volk de order gegeven om deel te nemen aan het driengi sweri, eed drinken, op Drietabbetje.

Wie den eed aan Grantata aflegt, doch eigenlijk een wisiman is, zal weldra sterven door het middel dat hij of zij heeft ingeslikt (§ 40). Iemand die gezondigd heeft tegen de leer van Grantata, doch niet bepaald een wisiman is, sterft eveneens door de hand van Grantata, vooral wanneer het geldt bloedschande. De dood behoeft niet terstond op de daad te volgen; soms duurt het jaren of tientallen van jaren. Men zegt dan ,na gado bai hem”, de godheid heeft hem gekocht, d.w.z. de godheid heeft beslag op hem gelegd. Voor een die zoo gestorven is, mag geen rouwfeest gehouden worden, geen

1) $2 \mathrm{~K} 214,232$ is in zooverre minder juist, dat daarin wel de drank, doch niet de eed wordt vermeld. 
enkele ceremonie verricht worden. Hij wordt in stilte begraven op de begraafplaats. Zijn bezittingen worden, evenals die van den wisiman, te Drietabbetje ingeleverd voor Grantata. Ook zijn dagelijksche gebruiksartikelen (die bij den wisiman vernietigd worden), worden aan Grantata ingeleverd.

Ook als een Djoeka ver weg woont van Drietabbetje, en bij het ronddragen van het lijk blijkt, dat hij een wisiman was, of door de godheid opgeëischt, dan worden nog al zijn goederen opgezonden naar Drietabbetje. Ik heb het bijgewoond, dat van iemand uit de Sarakreek zilvergeld ten bedrage van minstens f 700 aankwam (vroeger telde men in het 8-tallig stelsel; bij minder ontwikkelden kwam het voor, dat zij niet verder dan tot 5 konden tellen; zoo telde de granman Amakti met hoopjes van 5). Vrees, dat de familie het een of ander zal achterhouden, behoeft niet te bestaan; dat zou een bestelen van Grantata zijn, wat niemand zou wagen.

Het vloeken of zweren op een dorp ( $(41)$ kan soms groote gevolgen hebben: kindersterfte, misgewas, ook sterfte onder volwassenen, herhaalde rampen over het dorp of de bewoners. De oorzaak hiervan kan alleen worden opgeheven door een priester van Grantata. Op Drietabbetje houdt men een dienst waarbij aan Grantata vergiffenis wordt gevraagd; de priesters houden dien dienst en de schuldige, vergezeld door familieleden, is erbij tegenwoordig. Daarna gaat een van de priesters mee naar het dorp van den schuldige, die daar onder het prevelen van gebeden van Grantata, met bepaalde kruidenaftreksels de plaats waar de vervloeking werd uitgesproken, de wegen en het huis besprenkelt. De schuldige krijgt daarna onder leiding van den priester een zuiveringsbad in de rivier, waarmede de zaak is afgeloopen.

De priesters laten er zich zeer goed voor betalen, bijv. f 100 en 3 damejeannes (45 liter) rum in een ernstig geval.

Degene die gevloekt of gezworen heeft, gaat echter vrij uit, wanneer hij kan aantoonen, dat een ander hem geprovoceerd heeft. Heeft hij echter ernstig gevloekt of lag er veel tijd tusschen de aanleiding tot het vervloeken en het uitspreken daarvan, dan kan hij als medeschuldige gestraft worden.

Grantata beschermt zijn volgelingen bij al wat deze doen tot lijfsverweer, bij genezing zoeken, enz. Hun obia's en amuletten staan vanzelf onder bescherming van Grantata. Degene dus, die aan deze zaken hun werkdadige kracht ontneemt, pleegt in het oog vanGrantata een doodzonde. Als bijv. een vrouw die menstrueert, dat niet bekend 
maakt, en toestaat dat een man met haar praat, dan worden daardoor de obia's van dien man krachteloos $(\$ 45)$ en de vrouw heeft daarmede een doodzonde begaan. Het verzwijgen alleen, ook al is er niets bedorven, geldt reeds als doodzonde. Als een vrouw die zonde begaat, acht men het onmogelijk, dat het uit haar zelf zou zijn gekomen, doch meent, dat een wisiman haar verstand verward heeft.

Woordbreuk die geen gevolgen heeft gehad, waarvan dus niemand nadeel ondervonden heeft, telt niet, blijft veelal ook geheim. Sterft echter bijv. een jong meisje en komt bij het ronddragen van het lijk uit, dat ze is gestorven van hartzeer, omdat een jongeman aan wien ze zich op trouwbelofte had gegeven, zijn belofte niet gestand. had gedaan, dan wordt het een ernstige zaak voor den man en zijn familie. Boetedoening en vooral materieele boete zijn noodig om Grantata weder te verzoenen. Dadelijk nadat de zaak bekend is geworden heeft inmiddels de familie van het meisje, den man en zijn familie half dood geranseld, zoodat ze in het bosch moesten vluchten.

\section{$\S 20$. Gedeosoe.}

Gedeosoe (Gedewsoe, Agedeosoe), is een ongehuwde mannelijke of een bovengeslachtelijke god, en de andere der beide grangado's. Ook Gedeosoe is door een priester uit Afrika medegebracht. Deze, wiens naam Apasoe was, was foeileelijk en geen vrouw wilde hem hebben. Tot eindelijk een vrouw, Asafe, zich over hem ontfermde. Haar loon was, dat zij door hem in den dienst van Gedeosoe werd ingewijd en na zijn dood opperpriesteres werd. Op haar beurt leidde Asafe een harer dochters op en sedert bleef het opperpriesterschap van Gedeosoe in vrouwenhanden.

Bij de indeeling der lo's kwam Apasoe terecht bij de Pedri-lo en zoo kwam het priesterschap aan deze onderstam en werd Gedeosoe de bijzondere godheid der bilo-ningre ( $\S 1$ ) gelijk Gwangwella het is van de opo-ningre. De plaats van aanbidding werd Kriorokondre, doch sedert Kriorokondre niet meer bewoond is, wordt de heilige bundel of dgl., welke Gedeosoe vertegenwoordigt, in een tempelhuisje te Tabbetje bewaard en telkens als het groote feest te Kriorokondre zal plaatsvinden, daarheen overgebracht.

Gedeosoe is de god des levens, de godheid van de materieele dingen, van oogst en landbouw, vischvangst, jacht, geboorte enz. In den tijd van grondjes kappen is men verplicht eerst aan Gedeosoe te offeren en zijn bijstand te vragen voor het slagen van wat men 
zal ondernemen (het woud vellen, planten enz.). Voor de ponsoe, de vischvangst met vischvergift $(\S 80)$, moet de bijstand van Gedeosoc gevraagd worden en ook voor de jacht.

Het komt op gezette tijden voor, dat een kudde pingo's (wilde zwijnen) in de nabijheid van een dorp komt, of de rivier overzwemt. Wie dit opmerkt mag er niet meer dan twee voor zichzelf schieten en moet daarna alarm maken. Want Gedeosoe heeft ze niet voor één mensch, doch voor allen, gezonden. Dan komen van alle kanten mannen en vrouwen om een deel van den buit machtig te worden (ik heb wel eens 150 gedoode pingo's zien liggen).

Als een tapir gedood is, dan wordt de kop aan den Granman gebracht als een offer aan Gedeosoe. De geest van den Granman vertegenwoordigt hierbij Gedeosoe.

Misoogst, of tegenslag bij de ponsoe, moet in den regel worden toegeschreven aan verstoordheid van Gedeosoe. Men verzoent hem door aan hem te offeren. Eens bleven de pingo's uit en werd er weken lang op Kriorokondre geofferd en gedanst; daarop verschenen de pingo's weder.

Ook Gedeosoe moet op gezette tijden door den geheelen stam aanbeden worden; dit gebeurt niet te Drietabbetje of Poketi, doch op Kriorokondre. De offerfeesten duren weken, soms maanden aan een stuk door; Gedeosoe geeft veel, doch is niet minder veeleischend.

Elk jaar of om de twee jaar wordt de heilige bundel van Gedeosoe naar Drietabbetje vervoerd, alwaar dan allen, ook de Granman, deze godheid aanbidden. Het overbrengen van den bundel geschiedt door den hoofdpriester of -priesteres, bijgestaan door een aantal andere priesters; in de boot is een bel, die men voortdurend laat klinken (§ 63). Aan Gedeosoe wordt geen eed afgelegd.

Gedeosoe beschermt de vrouwen bij zwangerschap en bevalling en wordt bij kinderloosheid aangeroepen. Hij is ook de beschermer der kinderen en elke plechtigheid voor Gedeosoe vangt aan met een hulde die de kinderen brengen. Het heet, dat wat de gebeden van ouderen soms niet vermogen, op het gebed van kinderen door Gedeosoe wordt toegestaan.

[Holdridge 210 vermeldt, dat Gedeonsoe schijnt te leven in den grooten Ceyba-boom. Bij de Saramakkaners wonen de Gedeonsoe's, die overigens veel gemeen hebben met Gedeosoe der Djoeka's, in Ceyba-boomen. Volgens van Lier kan, evenals voor de lagere goden, ook voor Gedeosoe een gado-pree (feest waarbij men danst, eet enz.) gehouden worden, voor Grantata echter niet. Gedeosoe wordt ook 


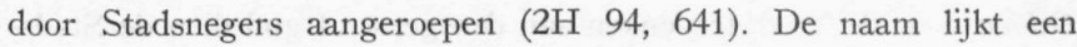
samenstelling van Gede (vgl. Kedi-ampon § 18) en Osoe of Onsoe (vgl. de vele met $O$ - beginnende afrikaansche godennamen vermeld door Ellis, Yoruba 34 vlg.). 1H 349 maakt melding van twee goddelijke broeders in Dahome, waarvan de eene, Gede, in een rots veranderde en de andere, Honsu in den grooten katoenboom ging. De godheid Gedeosoe der Boschnegers toont trekken van gelijkenis met de in $\S \S 22$ en 23 te bespreken natuurgeesten].

\section{$\S 21$. Odoen der Bonni's.}

De voorouders der Bonni's in Afrika waren van oordeel, dat Odoen, aangewezen door Nana, de wereld regeerde en geen andere godheid met nagenoeg gelijke macht naast zich had. Op een Bonnidorp, waar de $l o$ zich gereedmaakte om nieuwe grondjes open te kappen, zag ik hoe een groote offerdienst aan Odoen werd gehouden; men bad dat het werk goed zou afloopen en dat de plekken voor de grondjes uitgekozen, vruchtbaar zouden blijken te zijn. Enkele dagen later werd een jonge man bij het vellen van een boom door een tak getroffen; men hield een plechtigheid om aan Odoen vergiffenis voor den knaap te vragen, daar het ongeval zeker gekomen was, doordien de jongen een gebod van Odoen overtreden had. Op Poeloemoffo staat aan de landingsplaats een groot uit pimba (witte aarde) geboetseerd beeld, een grijsaard voorstellend; daarin is Odoen gesymboliseerd.

[Coudreau 248-250 kwam bij het afzakken der Marowijnekreek, de rivier waaraan in den ouden tijd de Bonni's woonden, bij de plek oedoe-gron, waar een Ceyba-boom, obia-oedoe stond, welks sap voor den eeddrank diende. De Bonni's gingen soms in grooten getale derwaarts om er den eed van zuiverheid af te leggen. Cr. 60 vermeldt, dat de boom die den eeddrank levert slechts aan den Granman en zijn luitenants bekend is. Vgl. ook Ellis Tshi 199, Ewe 97 : het hout waarvan de eeddrank bereid wordt heet odoem.

Het zooeven genoemde beeld, dat Odoen zou voorstellen, is waarschijnlijk hetzelfde, dat Crevaux in 1877 en d. G. e.a. in 1903 en in 1937 zagen. Cr. 43 beschrijft het als ,een ruw beeld van klei, opmerkelijk door zijn immens groote borsten. Dit soort godheid heet maman-gron (moeder der aarde)". $1 \mathrm{~F} 96$, met foto, meldt dat het Granmama Grong heet. Nog meer dan bij Gedeosoe, ligt het bij 
Odoen voor de hand, te denken aan den geest of god dien de Stadsnegers Gronmama noemen].

\section{$\S$ 22. Boesimama, Gronmama, Watramama (boschmoeder,} aardemoeder, watermoeder).

De Djoeka's gelooven aan bosch-, grond-, water- en luchtgeesten (§ 23). Een albino (bongkoro, gado pikien $=$ gods-kind) is het kind van een watergeest, welke geest een gado is, doch niet als obia of winti werkt.

[Zie voorts $\S 23$ Wittihedde. $1 \mathrm{bKp}$ vermeldt: Aan dezen boom [de Ceyba] dus werd door de Aucana Boschnegers goddelijke eer bewezen. Wanneer zij van hunnen dorpen kwamen, offerden zij vleesch en visch; van Paramaribo daarentegen terugkeerende, wijn of dram .... Behalve dezen afgod, die zijnen vasten tempel hier had, vertoonde zich op Armina somtijds eene godin van den hoogsten rang, de zoogenaamde Watermama. Men had haar eenige malen op de rots zien zitten. doch zelfs van hen, die voorgaven haar gezien te hebben, kon ik geen uitsluitsel over hare gedaante of kleur vernemen.]

SAR De tone's of watramama's hebben korte armen, korte vingers en staarten als visschen; ze wonen in het water, komen ook wel op den oever zitten en springen dan in het water als er menschen aankomen; soms laat zoo'n watramama de kam waarmee ze zich zat te kammen, liggen. Men noemt ze ook wel Watra-ingi (water-Indiaan) omdat ze met hun lang zwart haar op Indianen lijken.

De Watramama is niet hetzelfde als het dier de zeekoe (Manatus).

Een dergelijke watergeest kan in een kind komen en zoo'n kind noemt men een Tóne. Zoo'n kind is niet een gewoon mensch; het wordt niet vereerd, maar wel geacht. Het heeft een bijzondere kracht; bijv. als het groot wordt, weet het veel van medicijn; in den droom wijst een mensch hem, hoe medicijn te bereiden; het wordt echter niet een obiaman of wintiman. Men herkent zoo'n kind daaraan, dat het wit, blank is. De Europeanen worden echter niet als Tone's beschouwd. De van zoo'n kind zwangere moeder droomt van een rivier, of ziet een mensch met lange haren, een Tone, bij zich komen (vgl. $§ 10$ djodjo).

Als men met zoo'n kind naar de stad gaat, moet het onder een tent vervoerd worden; anders zou het water onstuimig worden en 
het varen bemoeilijken. Zoo'n kind mag geen grati fisi (visschen zonder schubben) eten, want daardoor zouden zijn lippen en mond gaan rotten; het mag ook geen pompoen eten en geen okro; sommige eten geen pinda's. Als zoo iemand sterft, dan wordt hij begraven bij den rivieroever ( $\$ 86)$. 1H 236 vermeldt hoe een vrouw door een Tone bezeten, een gesmoord geluid voortbrengt. (Het is merkwaardig dat ook de Arowak-Indianen zeggen, dat een kind van een mensch en een watergeest een gebrek aan het spraakgeluid hebben en dat vroeger ook in Europa zooiets werd verteld van de kinderen der Nixen, de Kielkröpfe. d. G.). 3J 161 vertelt van een kind dat in het water viel en een tijd bij den watergeest en regengod Tonnee woonde; dergelijke verhalen bij $2 \mathrm{~L} 13 \mathrm{vlg}$. (ook dit is iets dat bij andere volken bekend is).

STAD. De Gronmama is geen winti. Elke plek heeft zijn Gronmama; deze kan zich vertoonen onder de gedaante van een hert, tijger, kaaiman, dagowe-slang of aboma-slang (niet als uil, gelijk $2 \mathrm{H} 63$ vermeldt) en men moet daar niet op schieten. $\mathrm{Zie}$ voorts $2 \mathrm{H}$ 62-63, 89-91, 1P 172, 2P 23, Bex IV.

Boesimama, zie 2L 18-22, 2P 22, Bex IV.

Watramama. Watra-iengi, water-Indiaan, is een Indianengeest, die bij het water woont. Een van mijn zegslieden heeft gezien, hoe iemand, door een Iengi-winti bezeten, een vuur bluschte door erin te dansen en in een awara (doornpalm) klom. Wie een Iengi-wint: heeft, draagt een rooden hoofddoek en (zoo zeide een Arowak mij) verstaat een soort Indiaansch, eenige woorden Arowaksch en Kalienja door elkaar. Alle Iengi zijn wátra-soema (waterlieden). Iengi-zvinti is de bakra-dans, doch één enkele moet dansen, anders komt hij niet. Zie voorts $1 \mathrm{P}$ 26-31, 2P 22, 24, 2L 26, 2H 64-65, 57.

Een albino noemt men wel amienta (vgl. § 36 watergeest Minje Матта).

\section{§ 23. De gado's (winti's).}

De Djoeka bezigt het woord gado of gadoe (god) om het Opperwezen Nana en de Oppergoden Grvangwella en Gedeosoe aan te duiden, doch in het bijzonder voor die goden of geesten die, hetzij van geboorte tot dood met den mensch verbonden zijn (de gado of djodjo, $\S 10$ ), hetzij met een mensch op zoodanige wijze verbonden zijn, dat zoo'n gado hem nu en dan geheel kan vervullen, hij of zij bezeten is door den gado. 
Deze gado's hebben deugden en ondeugden, goede en kwade luimen en emoties als menschen; ze zijn echter onsterfelijk. Men onderscheidt boen gado's en ogri gado's (goede en slechte goden) en takroe sani's (kwade dingen). De handelingen der gado's zijn doelbewust, terwijl van de takroe sani's beweerd wordt, dat zij ondanks zichzelve en onbewust kwaad doen. Zie voorts § 24 (2) Ampoekoe.

Elke rivier of kreek heeft zijn eigen gado en bij de monding is een of ferplaats. Die gado's worden beschouwd te eten en drinken en gehuwd te zijn. Als men tot een Djoeka zegt ",maar ik zie toch niet, dat de gado het geofferde voedsel opeet", dan antwoordt hij joe no kan si, a njam ing na kraka, je kunt het niet zien, hij eet het in den geest (kraka $\S 7$; zie voor deze opvatting Inl. (6)). Als men in een stroomversnelling is, of in een kreek, dan moet men niet den naam van die stroomversnelling of kreek uitspreken. ( $\S 4,13)$.

Ook groote boomen, rotsen in de rivier of in het woud hebben een gado, die de streek rondom beheerscht. [Zie ook $2 \mathrm{~F} 35$ en betreffende de rots Witti sjtong of Witti hedde boven de Granhollovallen in de Tapanahoni (de naam reeds op de kaart van Henemann 1787) $2 \mathrm{Kp} 31$, Vidal 26, 1G 27, 57 met foto; volgens Sp 39 woont in die rots de opperste der watergoden, volgens $2 \mathrm{~Pa} 2$ de watergod

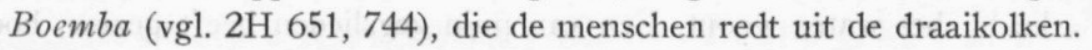
Over den rotsberg Teboe aan de Tapanahoni zie 2F 30-31. In 1936 was er op een rots in de Paloemeu in het zicht van den geweldigen rotsberg Kassikassima of Twaalfoehedde Teboe, een offerplaats. De Djoeka's der grensexpeditie verrichtten daar een gebed, sprenkelden suikerwater op de rots en plaatsten er een stok waaraan een nieuw pandje (kleedingdoek) (van Lynden 43 en foto no. 61)].

De Djoeka's onderscheiden tapoesei (in de lucht levende), ondro watra (in het water verblijf houdende), boesi (zich in het bosch bevindende) en grong (in of op den grond om en bij de dorpen en in de kostgronden wonende) gado's. Zie voor ordening der streek- of rivier-gado's naar weekdagen, kinadei $\S 25$.

De gado's met dierennaam zijn eigenlijk de groepsziel (akra of jorka) van de betrokken diersoort [dgl. bij de Saramakkaners, 3J 85]. Evenzoo bij planten. In bijna alle kankantri's (Ceyba) zit een geest; dit kunnen verschillende geesten zijn, ook geesten die de Djoeka's niet in een bepaalde groep weten onder te brengen, doch die zich plotseling als winti in iemand manifesteeren; het kunnen goede of kwade geesten zijn. Wie een kankantri omhakt, stelt er zich aan bloot, dat de geest van den kankantri in hem vaart en hem 
ziek maakt, of tot allerlei dwalingen brengt, zoodat hij van een eerbaar mensch een wisizvasi man (nonsens mensch) wordt.

De moordenaarsliaan abrasá (Clusia sp.) verstikt haar gastheer; in die liaan zit een gevaarlijke gado, Katoe. Zoo'n liaan of boom, de katoe-boom, mag nooit geveld worden.

Een boompje of tak, die met een knik gegroeid is, is een tra soortoe sani (ander soort ding, d.w.z. afwijking van de natuur) en in den knik zit een gado. Wie onvoorzichtig (of zelfs zonder het te bemerken, het orakel brengt het later aan het licht) zoo'n hout kapt, kan door ramp, ziekte of dood getroffen worden. Zie voorts $\S 54$ krontiki.

Dergelijke' opvattingen ook SAR en STAD.

d. G. 1937. In den kankantri en in den katoe-boom zit een gado; de Djoeka die een dezer boomen velt, sterft; een blanke kan het ongestraft doen.

SAR Geesten komen uit de lucht, niet uit je binnenste.

$\S 24$. Bijzonderheden van eenige gado's (winti's) en andere bovenzinnelijke wezens.

(1) Afrekete. STAD Dit is een winti. Als je hem ziet, is hij altijd melaats. Als iemand een Afrekete-winti over zich heeft, trekken

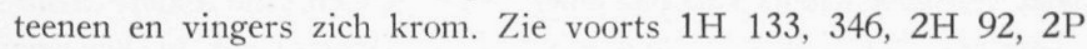
21, Bex III.

(2) Ampoekoe is de god der booze ziekten en van het verderf. Onder hem staan als zijn knechten takroe-sani (kwaad-ding), dat zijn geesten die ,het kwaad” zijn en kwaad doen zonder er zich van bewust te zijn. Op last van de een of andere godheid vatten zij post, op de wijze van een winti, bij den een of anderen mensch, bij een stam of in een dorp. Wanneer zij niet in functie zijn, wonen zij op onherbergzame, verafgelegen plekken in het woud.

Ampoekoe heeft ook onder zich de boeba-gado's, die hem helpen ziekte en verderf aan te brengen. Deze zijn hoofdzakelijk langs de boschpaadjes en om en bij kostgrondjes gevestigd. Het is niet gemakkelijk ze in bedwang te houden; talrijk zijn de offers die zij van de menschen vragen, welke offers hun in den vorm van dranken, lapjes gekleurd goed enz., ook wel eens in geld, gebracht worden.

Wanneer een Ampoekoe bij iemand is, kan men hem niet ver- 
drijven, doch men kan hem (of den boeba-gado) bekeeren, doen worden als de andere goden die slechts het heil der stervelingen begeeren, en dan is hij juist zeer hulpvaardig en actief (zie $\S 36$ en $2 \mathrm{H} 70$ ). Mislukt dit, dan sterft de betrokkene na meer of minder lijden of hij wordt krankzinnig. Zoo'n krankzinnigheid veroorzakenden $\mathrm{Am}$ poekoe noemen de Djoeka's ook lau-bakroe (gek-bakroc).

SAR Een soort boschgeest Apóekoe beschermt de gewassen. Er zijn menschen die weten hoe ze kruiden moeten bereiden voor zoo'n Apoekoe. Ze maken kruidenwater in een kalebas en besprenkelen den kostgrond, sprekende Apoekoe i moesoe mei di gong da mi njanja. Vruchtbaarheidsfeesten zijn er niet. - Als je in het bosch verdwaalt, dan komt dat door Apoekoe. Men kan krankzinnig worden, als men een Apoekoe tegenkomt. Krankzinnigen worden niet vereerd; er zijn menschen die ze weten te genezen. Zie ook $1 \mathrm{H} 347$.

STAD Apoekoe is een soort knecht van de winti; het zijn altijd kwaaddoeners. De winti kan hem sturen om iets goeds of om iets kwaads te doen. Apockoe is ook een winti, doch staat onder de andere winti's. Een wisiman ( $(48)$ kan geen Bakroe of Apoekoe maken, doch kan ze bemachtigen uit het bosch. Een Apoekoe kan zich zichtbaar maken als een klein kind met een groot hoofd.

(3) Asamani is het opperhoofd der andere winti's. Als bij een winti-dans Asamani vaardig wordt over een der aanwezigen, dan is dat een gebeurtenis van bijzonder groot gewicht; de andere winti's haasten zich dan hem alle eer en gehoorzaamheid te bewijzen. Asamani openbaart zich tegenwoordig nog maar zelden.

(4) Dagowee of papa-gado. Dagowee, de geest van den Boa Constrictor ${ }^{1}$ ) is een grongado (grondgod). Geen gado is zoo gevreesd als Dagowee en voor geen van hen worden zulke offerfeesten aangericht, als voor dezen. Dagowee is ongeloofelijk ijdel, zeer lichtgeraakt en razend jaloersch en heeft daarbij de macht, ziekte en dood over de menschen te brengen en vooral, hen tot het begaan van zonden te verleiden.

Is er een dagowee-slang op het dorp, die de eieren en kuikens opeet, dan zal men haar niet dooden of verjagen, doch men offert dagelijks aan haar en smeekt haar weer heen te gaan. Geeft zij geen gehoor aan deze beden, dan worden groote offerfeesten aangericht; de obiaman's worden uitgenoodigd hun gado-dansen uit te voeren en

1) Van Lier meent, dat de dagowe of afgodsslang is de tapijtslang, Epicrates Cenchris; ook een Stadsneger zeide mij dit. Zie nog $2 \mathrm{H} 64$. 
dagen en nachten lang wordt er gedanst. Veel en lekker eten en kalebasschalen vol eieren worden telkens voor den gado neergelegd, enz.

Als men het bosch heeft geveld en afgebrand om een kostgrond aan te leggen, gebeurt het, dat men bij het opruimen het skelet van een dagoweeslang vindt. Degene die dit ontdekt, steekt ter plaatse eenige stokjes met wimpels van gekleurd doek in den grond en waarschuwt terstond den priester. Deze begeeft zich met spoed naar de plek, plengt een offer en smeekt den gado om vergiffenis.

N.B. Er is geen sprake van, dat men een slang in huis zou hebben. Ontdekt men, dat in een ledige korjaal een slang heeft gelegen, dan moet die korjaal met gebeden en offers en bladerensappen en pimba ( $\S 57,56)$ ontsmet worden.

Een man had zich vergist in een kadaver van de dagowee; het was reeds met groote plechtigheid begraven, toen men ontdekte, dat het van een andere slang was. De plechtigheid moest ongedaan gemaakt worden; men herriep alle eerbetoon en de stokjes met wimpels bij het graf werden geschonden. Toen ik vroeg ,waarom?”, was het antwoord: „ja, hij was geen gado; de papa gado zou het kwalijk nemen dat men een ander dit eerbetoon had gegeven".

Dagboek d. G. 29 Juli 1907 te Drietabbetje. Vriend Sonie zal niet mee kunnen gaan (met de expeditie): hij heeft het aangelegd met een nichtje van hem, die voor hem haar man verliet. De familie was daarover nogal verstoord, doch de gelieven verklaarden, dat slechts de dood ze zou kunnen scheiden. Toen werd in een gadoe-hoso in een mierengat dood gevonden een slang. Men onderzocht deze, en bevond aan den driehoekigen kop, dat het een afgodsslang was. Het lijk werd op een plankje gelegd, en door twee man rondgedragen, en de geest van de slang verklaarde dat de dood het gevolg was van de handelwijze van de beide jongelui. Kort daarop werd een hond in het bosch dood gevonden, en wat later stierf een kind in de familie. Dit alles was klaarblijkelijk aan dezelfde oorzaak te wijten. Sonie moest het nu afkoopen, om den slangengeest ter ruste te doen gaan; en daarvoor was hij twee maanden geleden te Albina, om inkoopen te doen. (Vgl. nog 1G 47).

SAR Wódoe heet de geest van de lánga-lánga (zeer lange) of Sindéki (Boa Constrictor, dagowee-slang). Men doodt deze 2 of soms $3 \mathrm{~m}$ lange slang niet, en evenmin de aboma (waterboa, Eunectes murinus), waarin ook een geest is. Als men deze slang doodmaakt,

D1. 99. 
komt die geest bij je en je moet zijn wil doen. Andere slangen dooden ze wél.

Ontmoet een Neger een land-boa, dan zegt hij tot deze: ,ik ben maar aan het wandelen en kom niet om je kwaad te doen; je moet mij niet blind maken”. Want het heet, dat deze slang door zijn veelkleurigheid blind kan maken.

STAD Wie een dagoewee-zinti heeft, draagt een witten hoofddoek. De dagoewee-winti maakt, dat zijn drager geld krijgt.

Als je een dagowee-zvinti krijgt, dan komt 's nachts een dagoweeslang bij je; je geeft haar eieren en ze schuift weg; op vele erven, djari, is zoo'n slang; ze geeft geluk aan het erf.

Er zijn kinderen van 12, 13 jaar, die reeds een dagowee-winti hebben. Dagowee is ,basi winti”, de hoogste aller winti's. Zie voorts $2 \mathrm{H} 63-64,1 \mathrm{P}$ 174-175.

(5) Dahome is genaamd naar de streek van Afrika vanwaar deze gado met de Negers kwam.

(6) Dinga wijst de kruiden aan voor kwalen van vrouwen of voor moeilijke bevalling.

(7) Djadja, de tijgerkat, geldt als oudere broeder van Djibri, de jaguar, omdat de tijgerkat met beide voorpooten de prooi kan grijpen.

Het komt voor dat de hasi (drager) van Djibri bezig is met een genezing en dat dan eensklaps Djadja vaardig wordt over een andere hasi en mededeelt, dat hij de behandeling overneemt. Djibri blijft dan helpen en tracht daarbij tevens zijn geleerdheid te vermeerderen.

(8) Djasofoe verricht niet, gelijk de andere gado's, genezingen, doch heeft de macht elken boozen geest, waar die zich ook bevindt, te verdrijven. Hij openbaart zich tegenwoordig steeds minder.

(9) Djibri, de jaguar, dringt overal het woud door, ziet veel en weet dus ook waar de geneeskrachtige kruiden het vlugst vandaan te halen zijn. Wordt ook Djebri of Djebi genoemd.

SAR Tígri-bája is een soortgelijke dans als Komanti. Men draagt den schedel van een tijger (jaguar of dgl.) en de beenderen van doode dieren. In den grooten tijger is de geest Boebóe (Schu 57 boeboe, tijger); daarom doodt men dit dier niet, tenzij bij gevaar.

STAD Zie $2 \mathrm{H}$ 66, $1 \mathrm{P} 175$.

(10) Jauw consulteert slechts met andere gado's; tegenover deze is hij mededeelzaam, doch menschen krijgen weinig uit hem.

(11) Kaiman. Ook in den kaaiman, of in een grooten kaaiman, is 
een geest aanwezig, of althans ontziet men hem (Vidal 40, de Leeuw 76); eveneens bij de Saramakkaners (Stn III/1/135 en West-Ind. Gids XXI, 213, 1H 312); en zie § 22 Gronmama.

(12) Kantamasoe of Kantamasi kiest zijn woonplaats bij voorkeur in termietennesten; komt er schuim uit zoo'n nest, dan is dit een teeken, dat de $\mathrm{K}$. aanwezig is; het is een booze geest.

SAR Akantamasi is een termietennest. Als een landbouwer bij ongeluk zoo'n nest verbrandt, dan komt de geest daarvan, die Sindomáh heet, of Ba-áka sombe (zwart mensch) in hem.

STAD Akantoemasi of Akantamasóe is de geest die in een termietennest woont; evenals Apockoe staat hij onder de winti. Kantamasi is een booze geest, zeer twistziek. Het defeceeren in zijn nabijheid wreekt hij altijd door ernstige ziekte en vaak door dood. Als Kantamasi of Amasji-zvinti slecht is, geeft hij je den bloedloop. Mijn zegsman ontkent dat Kantamasoe en Apoekoe (1P 178) dezelfde zouden zijn.

(13) Kromanti. Wie door Kromanti-gadoe vervuld is, kan zonder zich te kwetsen, in het vuur gaan, ook in een in het vuur gloeiend gemaakte bijl bijten, in een awarra-palm (met groote dorens) klimmen en dansen door glasscherven. Kromanti-gado is de god der geneeskunde; zijn gezag strekt zich uit over een aantal kleinere goden, de liefelijke en vaak guitige Boensoemoenki's, die in het water wonen, en over zeer vele gado's, als Diibri, Opete, Dagowee enz., die alle de geneeskunst uitoefenen. Aan Kromanti-gado is de zorg voor de gezondheid van mensch en dier toevertrouwd. Breekt er een epidemie uit (hij kan dat niet voorkomen, dat kan alleen Nana, het Opperwezen), dan wordt zijn hulp ingeroepen om de ziekte te bestrijden en er worden hem talrijke offers gebracht. Kromanti leeft in voortdurenden strijd met Ampoekoe, den god van de booze ziekten en het verderf.

SAR Zie $\S 37$ en $1 \mathrm{H}$ index p. 361. Een man die goed is in Komanti, kan niet een geweer lang bezitten; het gaat vanzelf stuk.

STAD Wie een Kromanti-winti heeft, draagt een witten hoofddoek. De Kromanti-winti (van Afrika) komt als vanzelf bij je vanaf dat je een klein kind bent; ze is een zuster van Dagowee. Zie voorts $2 \mathrm{H} 66 ; 1 \mathrm{P} 177$ houwer-winti is een Kromanti-winti. [Kromantiwinti heet uit Afrika afkomstig te zijn; de afrikaansche taal die de bezetenen spreken, heet Kromanti, en deze geest heeft te do:n met ijzer, wapenen en onkwetsbaarheid en geneeskunde. Wellicht is dat alles uit Afrika meegebracht. d. G.]. 
(14) Lebba. Deze geest is bij de Djoeka's, Paramakkaners en Saramakkaners niet bekend.

STAD Lebba is een soort winti, die over je kan komen; meestal is het een slechte geest. Evenals de djodjo ( $(10)$ kan ook een lebba een kind brengen. Eischt dan de lebba belooning en krijgt ze die niet dadelijk, dan brengt ze terstond melaatsheid; wordt daarna de belooning gegeven, dan verdwijnt de melaatsheid na een paar dagen.

Aan de Lebba offert men meestal op een kruisweg of bij een koker (sluis) of hoek.

Een andere zegsman vertelt: Lebba is een boschgeest, een boos wezen, heeft palmbladeren om het lichaam, đie sakka-sakka (geluid van den rammelaar) doen. Als je schrikt, loopt hij achter je aan en maakt je ziek. Ik heb een half jaar geleden er een gezien nabij de Herrnhutter kerk om 12 uur 's nachts; ik ben weggeloopen en ontsnapte; hij riep achter mij aan hoeoe.... hoeoe (met hooge stem).

Zie uitvoeriger $2 \mathrm{H} 15,67-68,108,1 \mathrm{P} 165-167$ en foto 5, 2P 21-22, Bex III. Is ook de naam van een godheid of geest in Afrika en bij de Negers in Brazilie en op Haiti.

(15) Loango is genaamd naar de streek in Afrika waar hij met de Negers vandaan kwam.

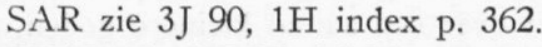

STAD zie $2 \mathrm{H} 72$, 95-96.

(16) Manningre (= volwassen man). Van dezen geest wordt gezegd, dat een manningre-obia onkwetsbaar maakt tegen kappen met houwer of bijl. Zie voorts $\S 57$.

(17) Opete is de geest der gieren die men stinkvogels noemt.

SAR De stinkvogel, opete of djanko [Fo 23 djankro] geheeten, mag geschoten worden. (3J 85 De werkelijke Opete is geenszins de gewone aasgier, die men in de kolonie stinkvogel noemt).

STAD zie $1 \mathrm{P} 176$ en foto $11,2 \mathrm{H}$ 78-79.

\section{$\S 25$. Kinadéi.}

Kinadéi beteekent feitelijk rustdag (kina $\S 13$, déi dag). Er zijn bepaalde streken in het woongebied der Djoeka's, waarvoor bepaalde dagen als kinadéi gelden. Bijv. is voor de streek rondom Pauwi aan de Tapanahoni, de Vrijdag kinadéi voor den rechteroever en de Maandag kinadéi voor den linkeroever. Op den kinadéi mag niemand het bosch van het betrokken gebied betreden. Ook gedeelten van rivieren kunnen elk hun kinadéi hebben; men mag er dan geen visch 
vangen, wel langs varen, doch geen leguanen schieten, lianen halen enz.

De gedachte die hierbij voorzit, is, dat elke rivier of streek zijn eigen gado heeft en men dien niet op zijn rustdag mag storen. Die dagen zijn van geslacht op geslacht overgeleverd en hoe men aan de keuze gekomen is, is niet meer bekend. Het zondigen tegen de kinadéi kan vaak heel gevaarlijk voor den schuldige zijn. Ziekte en ongelukken kunnen er het gevolg van zijn.

[C 4 Voor den bloedseed werd een Vrijdag, zijnde bij hen een heilige dag, uitgezocht. - Feesten waarbij men de gado's danst, beginnen steeds op Vrijdag].

SAR. en STAD. Elke winti heeft zijn eigen heiligen dag waarop

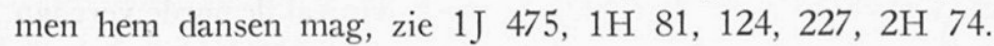

\section{§ 26. Totemdier $\left.{ }^{1}\right)$.}

Elke lo heeft een dierengeest, die haar beschermt en voor de menschen van die $l o$ is het eten van dieren van die soort, kina. Zoo mag op Clementi niemand kwatta-aap eten. J. E. Loth 345 vermeldt: „Dieren verheffen zij om verschillende redenen tot kina's, d.w.z. beschermde dieren. Zoo werd mij o.a. zeer dringend verzocht een buitengewoon lastigen boomkikvorsch, die mij het slapen onmogelijk zou maken, niet te verjagen, daar deze een kind van mijn kanobestuurder was. Voor het eiland Drietabbetjes zijn de papegaaien een kind, omdat door toedoen van zoo'n dier, in het dorp Mansi twee vrouwen van Drietabbetjes gered werden" (ook vermeld $5 \mathrm{H} 724$ ).

\section{$\S 27$. Hond.}

Een hond mag niet gedood worden, omdat anders een koenoe over den schuldige zou komen. Dit geldt i.h.a. van een huisdier, of zelfs van elk dier, behalve wanneer men het noodig heeft als voedsel, of wanneer het gevaar oplevert. Een Djoeka wiens hond oud en zwak en half blind was, bracht hem weg en toen de hond telkens weer terug kwam, wilde hij hem op een eiland brengen en de pooten stukschieten, maar niet dooden! [Van een amulet werd gezegd, dat het van den hondengod was. d. G.].

SAR Honden doodt men niet; er is geen geest in een hond, doch

1) Het gebruik van het woord totem, in dit yerband, blijve voor rekening van den heer yan Lier. - d. G. 
wie een hond doodt, doodt zichzelf, sterft ook; de hond heeft macht. Wie bij ongeluk een hond doodt, moet een kruidenbad nemen en veel betalen. Door het dooden van een hond krijgt men dago-koenoe (hond-vloek); deze werkt echter niet op de familie.

\section{$\S 28$. Hemel en hemelverschijnselen.}

d. G. : Men vertelt, dat vroeger de hemel met de wolken zoo dicht bij de aarde was, dat men ze met de hand aan kon raken. Een landbouwer stak bij ongeluk met zijn gereedschap in den hemel, en toen heeft God den hemel hooger gebracht.

De regenboog (moentjama) is, dat God (het Opperwezen) ons aanziet. Verschijnt er geen regenboog meer, dan zal de aarde vergaan. Van zon, maan en sterren weet men niets te vertellen.

Donder en bliksem als aankondiging van hevige onaangenaamheden met de blanken $1 \mathrm{G} 37$.

SAR Zon, maan en sterren worden niet vereerd.

\section{§ 29. Anansi.}

Anansi, de slimme spin, is de held der anansi-tori's, de spin-verhalen, die Boschnegers en ook Stadsnegers vertellen bij een doodenfeest ( $\S 84,91$ en $2 \mathrm{H} 138$ vlg.). De Djoeka’s beschouwen Anansi als een gado.

Het vertellen van anansitori's is een vereering van Anansi, want de Djoeka's kunnen niet zonder Anansi. Ze roepen Anansi ook wel aan, bijv. ,ho Anansi, fa joe de go doe nanga mi tidéi?" (he $A$., hoe ga jij vandaag met mij doen?). Die vraag doen ze 's morgens bij het op jacht gaan en de bedoeling is: zal ik succes hebben.

IV. Gemeenschap met het bovenzinnelijke.

\section{$\S 30$. Teekens.}

(1) Men kan een uitspraak van een bovenzinnelijk wezen verkrijgen op de volgende wijze: twee mannen dragen op het hoofd den op een plank gebonden heiligen bundel van een godheid ( $\$ 54)$. Een priester of oudere stelt vragen, en aan de bewegingen der dragers leest men af, wat de godheid antwoordt ( $\$ \S 19,34$, foto $1 \mathrm{G} 44)$. Of men draagt op dezelfde wijze een lijk en de jorka van den doode antwoordt ( $\$ 82$, plaat $\mathrm{Cr} 61 ; \S 24$ (4) lijk van een afgodsslang). 
(2) STAD Ėen loekoeman kan de akra van een levende ondervragen ( $(5)$, of de $d k r d$ van een afwezige of een anderen geest oproepen, waarvan mij door een Saramakkaner de volgende beschrijving werd gegeven: De loekoeman doet in een pot kruidenwater, pimba enz. en roept er een geest bij op, bijv. een jorka of een Akántamasi, zet de pot op het hoofd van den bezoeker en vraagt ,heeft $Q$. dit gestolen?". De geest in den pot doet door een voorwaartsche of zijdelingsche beweging van het hoofd van den bezoeker, uitspraak (zie ook 1P 160).

(3) Seti monsonio noemen de Djoeka's het volgende: Om iemand te laten bekennen, neemt men twee stengels van de plant monsonio (grassoort Andropogon Bicornis) en legt die den persoon, die zittende is met het hoofd achterover, gekruist over den strot. Glijden die stengels af, of blijven ze los liggen, dan is de persoon onschuldig; sluiten ze zich, zoodat de persoon ademnood krijgt, dan is hij schuldig en sommigen zullen dan bekennen.

Enc 483 beschrijft iets dergelijks van Stadsnegers; Stn II/2/63 vermeldt een andere variatie: om een dief te ontdekken legt de obiaman snijgras op den grond, en plaatst zijn handen daaronder; een voor een moeten de verdachten hun nek daarop leggen; verwondt het snijgras, dan bewijst dit de schuld.

(4) De Stadsnegers noemen seti sroto (sleutel plaatsen) het volgende: Men neemt een sleutel en steekt dien tusschen de bladeren van een Bijbel met het handvat naar buiten en bindt den sleutel aan den Bijbel vast. Twee menschen houden het handvat van den sleutel door het te laten rusten op de vingers en nu vraagt de loekoeman die erbij is : ,is het A. die het gedaan heeft?". Men wacht even en als er niets gebeurt, vraagt men verder of $\mathrm{B}$. het gedaan heeft; enz. Bij een naam gaat plotseling de sleutel zwaaien en vliegt met Bijbel en al uit de handen en daarmede is de schuldige uitgevonden. Als deze nu niet bekent, dan krijgt hij een mekoenoe over zich. (Ook Bex XVIII vertelt hiervan, ietwat anders).

(5) Een Saramakkaner vertelde mij het volgende: De loekoeman neemt een tong van een mauritiepalmblad en draait daarvan een zeer dun touwtje. Hij legt zijn houwer op het vuur tot deze roodgloeiend wordt. Nu stelt degene die iets vernemen wil de vraag, bijv. ,zal P. sterven (of in leven blijven)”, of ,heeft Q. dit gestolen?”. De loekoeman brengt het touwtje op den gloeienden houwer; wordt het doorgesneden, dan is de gestelde vraag berestigend beantwoord; het heet koti saa. Stn III/3/136 vermeldt, hoe e en van giftmengen verdachte 
het been met bananensap wordt bestreken; dan haalt men er een gloeiend ijzer over; schroeit het, dan is de betrokkene schuldig.

(6) SAR Stn II/2/78, 264. De obiaman steekt den verdachte een veer door de tong; knikt de veer, dan was hij of zij schuldig (ook, Schu 76 en, ietwat anders, $1 \mathrm{H}$ 204-205).

(7) De Djoeka's slachten in sommige gevallen een haan, om aan de kleur der testikels iets af te lezen ( $2 \mathrm{Kp} 370,1 \mathrm{G} 53)$. 1L 82 vermeldt: Heeft een groot offerfeest plaats gehad, dan wenschen de offerbrengers zekerheid te hebben of het offer al dan niet door de godheid is angenomen. Die zekerheid wordt door middel van een haan verkregen. Op de offerplaats verzamelen zich op den middag na de laatste ceremoniën van de offerdiensten, allen die bij de zaak waarvoor geofferd werd, betrokken zijn. De priester komt dan in het midden staan en aan hem wordt een groote haan overhandigd, dien hij met duim en wijsvinger bij het vel, aan den nek achter den kop aanvat. Op deze wijze wordt het dier in de hoogte gehouden. Na enkele seconden krijgt het ademnood, begint met de vlerken te klappen (hò, na gado de kon, he, de god is gekomen, wordt er dan gefluisterd) en verstikt. Hierna wordt de verstikte haan opengesneden en zekere lichaamsdeelen onderzocht. Zien beide deelen er zwart uit, dan is het offer afgewezen, en mag men van voren af aan met gebeden en boetedoening en opnieuw offeren beginnen, net zooveel keeren tot men bij het openleggen van den haan beide bewuste lichaamsdeelen van een lichte kleur bevindt.

Stadsnegers, zie $2 \mathrm{H} 48,57,83$.

\section{§ 31. Droomopenbaring.}

Een Boschneger heeft zelden een droomopenbaring (zie echter Stn II/2/269 en Burkhardt 47-48), een Stadsneger dikwijls. Zie voorts Lampe 548, Bex VI, 2H 483-487.

\section{$\S 32$. Verschijningen.}

Het is een zeer gewoon verschijnsel, dat een Boschneger een verschijning van een geest heeft, die alleen maar verschijnt, zonder hen iets mede te deelen. In zoo'n geval zal de betrokkene zoo spoedig mogelijk water plengen aan de fragatiki ( $\$ 55)$ en den Granjorka's vragen om bescherming, voor het geval de verschenen geest kwaad in den zin had. Zie nog § 36.

SAR Zie Sta 259, 262, waaruit aangehaald: „Het lichaam leeft 
voort, zegt de Saramaccaner. En het zou meerdere malen zijn voorgekomen, bij dag of nacht, dat een familielid, een vriend of kennis van een afgestorvene, het doode lichaam plotseling ziet langs loopen en weer verdwijnen". Iets dergelijks is ook in Afrika bekend (mededeeling Dr. S. Hofstra).

STAD Zie vooral $2 \mathrm{P}$. De geesten die den Neger verschijnen, zijn meestal, of uitsluitend, jorka, bakroe en lebba. Voorts vertellen $2 \mathrm{~L}$ $8-9$ en $2 \mathrm{H} 67$ van een vuurverschijning, Fajaman of Faja-mama ( $f a j a=$ vuur), $2 \mathrm{H} 67$ in verband met den kankantri (Ceyba-boom), hetgeen doet denken aan indiaansche mythen.

\section{§ 33. Aangeboren bijzondere vermogens.}

Sp 39: Voorts worden alle idioten gerekend te behooren tot de godenwereld. $2 \mathrm{Kp}$ 367: Al het buitengewone, zooals kreupelen, idioten enz. die bij de Negers volstrekt niet zeldzaam zijn, worden voor heilig gehouden en godenkinderen, gado pikien genoemd. Ho II 267 vermeldt ,eene dwergin, die men goddelijke eer bewees. Dit is ook bij tweelingen het geval”, vgl. §§ 11, 35).

Albino's hebben een watergeest in zich $(\$ \S 22,86$, ook Saramakkaners).

SAR Ze vereeren het, als iemand een tweeling krijgt en spelen of dansen ter eere daarvan Tocmii (tweeling). Zie ook Sta 587, 1H 218.

STAD Een sakka-pikien (met den helm geborene) kan jorka's zien; de jorka's kunnen zoo iemand geen kwaad doen.

Dr. Benjamins (1850-1933) vertelde mij : „Als kind werd ik na donker door een meid (Negerin) naar huis gebracht en wij kwamen langs een kerkhof. Mijn geleidster wilde, dat ik aan de van het kerkhof afgekeerde zijde van haar ging loopen; „want”, zoo zeide ze, , ik ben een sakka-pikien en kan de geesten zien". Wu 214 spook jorka, jroka. 2P 20: Jorka's zijn zichtbaar voor obiaman's, voo: menschen die met den helm geboren zijn, aan tweelingen en aan hen die na een tweeling geboren zijn (dosoe, $2 \mathrm{H} 42$ ). Ze zijn ook zichtbaar aan kinderen die door de moeder zoo worden gedragen, dat ze over haar schouder naar achteren kijken. MK XX noemt de moesocpikien (met den helm geborene; het vlies, gedroogd en als poeder op de pap gestrooid, wordt het kind ingegeven), tetei-pikien (door de navelstreng omwondene) en djodjo-pikien ( $(10)$ die geesten kunnen zien. De djodjo-pikien heeft de bijzondere gave dat hij als hij winti krijgt, de winti-mama, den geest die hem alsdan verschijnt, kan noemen. 


\section{$\S 34$. Priesters en priesteressen der Oppergoden.}

Benpenimausoe, opperpriester van Gzvangwella, was, tot kort voor het optreden van Amakti ( $(1)$, de Granman. Tusschen dezen hoogepriester en Grantata, aanwezig in den heiligen bundel, worden de diepste geheimen besproken. Voor de dragers van den bundel worden dan ook bijzonder betrouwbare personen genomen. Ik heb wel eens een geval bijgewoond, waarin vermoedelijk belanghebbenden met de dragers hadden afgesproken, dat zij een vraag zouden stellen en Grantata daarop een bepaald antwoord zou geven door middel van de bewegingen der dragers (welke gelden als het willoos werktuig van de godheid). De hoogepriester doorzag dit wel, maar dorst niettemin de uitspraak van Grantata niet te veronachtzamen.

De Otterlo is de lo van de Gwangwella-priesters en van den Granman; iemand die niet uit deze $l o$ is, kan geen priester worden. Alleen mannen kunnen Gwangwella-priester zijn. Onder de priesters heeft de een den naam van hooger bekwaamheid en meer invloed bij de godheid, dan de ander. Het priesterschap is erfelijk, doch er is ook een opleiding noodig.

Geen mensch kan aan Gwangwella offeren of zijn hulp voor het een of ander inroepen, zonder tusschenkomst van een Gwangwellapriester. En daar Gwangwella's hulp in alles noodig is en de Djoeka's zeer godsdienstig en vroom van zin zijn, is de invloed der priesters op het volk zeer groot en bestaat er ook een zekere vereering voor hen.

De priesterwetenschap is voor een groot deel kennis van de kruiden welke men voor verschillende doeleinden noodig heeft en die met water gemengd of uitgeperst worden ( $\$ 57)$. De priesters zoeken uit de priester-lo hen uit, die aanleg toonen tot het priesterschap en nemen die in de leer. Wanneer de leerling voldoende op de hoogte is en blijken heeft gegeven de vereischte bekwaamheid te bezitten, dan wordt aan Grantata gevraagd (door ronddragen van zijn paket, $\S 54$ ), of deze hem aanneemt als priester. Is het antwoord bevestigend, dan wordt de noviet gewijd doordien de priesters met hem naar de fragatiki gaan en aan de Granjorka's water plengen, hun vragende den jongen priester bijstand te verleenen, opdat hij zijn werk naar behooren kan verrichten. $\mathrm{Nu}$ is de jonge man priester, doch uit bescheidenheid, zal hij zich de eerste tijden nog op den achtergrond houden.

De priesters laten zich zwaar betalen voor de diensten die zij ver- 
leenen, als daar zijn: de oorzaak van opvolgende sterfgevallen aan Grantata vragen en het middel om dit op te heffen aan de hand te willen doen; opheffen van de schuld door een zonde tegen de wetten van Grantata (,, a misi a gadoe”, hij heeft gezondigd tegen de godheid). Bij doodzonden komt de Opperpriester te pas.

Zijn er bijv. langdurig zware regens, tot schade van het veldgewas, dan meent men, dat de stam der Djoeka's misschien door 'een of meer van zijn leden gezondigd heeft, of dat de oorzaak kan zijn, dat er niet de hand aan is gehouden, den eed aan Grantata te vernieuwen; de geheele stam wordt dan voor het vernieuwen van den eed naar Drietabbetje opgeroepen.

De Pedri-lo, de lo der Tabbetje-negers, is de lo der Gedeosoepriesters. Opleiding en wijding geschieden op overeenkomstige wijze als bij de Gwangwella-priesters, doch er worden weinig Gedeosoepriesters opgeleid, opdat de priesters meer zullen verdienen en grooter invloed zullen hebben.

Gedeosoe wordt bediend door een hoofdpriesteres, bijgestaan door priesteressen en priesters. Ook bijv. een gehuwde, wiens (wier) echtgenoot(e) geen priester is, kan priester(es) zijn.

De priesters van Grantata en Gedeosoe zijn als regel geen obiaman (§ 36); naar men mij zegt, wordt over iemand van de priester-lo nooit een gado vaardig. [Hieruit zou men opmaken, dat deze hooge goden in hun priesters doorloopend actief zijn, vgl. $\$ 70$ eerste zin en $3 \mathrm{~J}$ 158].

\section{$\S 35$. Tweelingpriesteres.}

Aan een tweeling-god ( $(11)$ kan slechts geofferd worden door bemiddeling van een tweeling-god-priesteres, zijnde een oude vrouw die zelf moeder is of geweest is van een tweeling, waarvan beiden nog leven of die eerst nadat ze volwassen waren geworden, zijn gestorven.

\section{§ 36. Priesters der lagere goden. Bezetenheid.}

Het magisch vermogen der in $\S \S 12,23,24$ vermelde gado's. noemen de Boschnegers obia. De Djoeka is levenslang met een dergelijken gado verbonden, die zich gedraagt op de in $\S 10$ beschreven wijze. Doch velen [C 41 zegt zelfs ,meest alle boschnegers"] zijn bovendien met een of meer andere gado's verbonden op een zoo- 
danige wijze, dat zoo'n gado (slechts één tegelijk!) af en toe zijn drager (hasi = paard, geheeten) geheel vervult, hem tot een bezetene maakt. Zoo iemand noemt men obiaman. In zooverre als de obiaman gebruik maakt van zijn vermogens, om anderen te helpen, kunnen wij hem priester van den betrokken gado noemen, of priester-dokter, medicijnman $^{1}$ ).

Een goede gado is erfelijk en gaat bij den dood van zijn drager over in diens zoon of neef; als een vrouw sterft, of oud en suf wordt, gaat haar gado over in een vrouwelijk familielid.

De obia kan, zonder dat er een voorbereiding aan is voorafgegaan, vaardig worden in den betrokkene. Deze ontwaakt uit den slaap en spreekt plotseling Kromanti (\$ 2); het kan ook overdag plaatsvinden.

In den beginne spreekt hij meestal verward en is wat hij zegt niet goed begrijpbaar. De oudere obiaman's maken dan hun werk ervan, den betrokkene tot zich te trekken; ook hun obia's (winti's) worden alsdan vaardig over hen. Die obiaman's vragen dan aan den gado die zich nieuw openbaart, wat zijn naam is (bijv. Djibri, Opete, Dagowee), waar hij vandaan komt en met welk doel hij zich in dien persoon heeft geopenbaard. Het kan zijn, dat het antwoord onmiddellijk komt, het kan ook zijn, dat het eerst komt als de betrokkene een volgend maal in extase geraakt. Het kan ook lang duren voordat de gado zich duidelijk uitdrukt en niet meer verward praat.

Om te verkrijgen dat die gado zich duidelijk uitspreekt, wordt soms een geheele behandeling toegepast. De betrokkene krijgt kruidenbaden, wordt ingesmeerd met smeersels uit kruiden bereid, waarbij pimba (§ 56) is gemengd; en er wordt hem een leefregel voorgeschreven, bijv. om zich van bepaalde spijzen en dranken te onthouden; bijna altijd wordt geslachtsverkeer, en zelfs het spreken met een vrouw, hem verboden.

Het kan een goede geest zijn, doch ook een booze, bijv. een $\mathrm{Am}$ poekoe. Een boozen geest vraagt men om weer heen te gaan, of om zich te bekeeren.

Soms vraagt een oudere, bijv. een oom, uit genegenheid aan een

1) $1^{\circ}$ Den Djoeka's is ook het woord winti, begeestering, der Stadsnegers (\$ 37) bekend. $2^{\circ}$ In oudere berichten over surinaamsche Negers wordt dikwijls het woord "gadoman" gebezigd om "priester" aan te duiden; het is veelal niet uit te maken, of daarmede priester van een hooge godheid, of obiaman bedoeld wordt. In de stad bedoelt men met gadoman, iemand die aan winti-dans doet. 
jongen bij wien hij aanleg vermoedt, om zich een gado te laten geven, opdat de ervaring en de kennis van den oudere bij diens dood niet verloren ga.

Dikwijls komt het voor, dat een jonge man zich aangetrokken voelt tot het vak van obiaman en voor veel geld en goede woorden door een of meer oudere obiaman's wordt opgeleid. De meester schrijft hem kruidenbaden voor, te gebruiken op bepaalde uren van dag en nacht. Er komt bij het verbod van geslachtelijken omgang en elken omgang met de andere sexe (de man mag niet eens eten wat zijn moeder voor hem kookt); ook penitenties, bijv. vasten en gedurende eenige dagen slechts het hoogst noodige om in leven te blijven, tot zich nemen; geslagen worden met een heet gemaakt kapmes (gilt de jongen, of krijgt hij een groote brandwond, dan is dat een teeken, dat zijn voorbereiding nog niet voldoende was, in den regel ook, dat hij niet voldoende aanleg heeft). Penitenties zijn ook, sap van bijtende kruiden, zelfs van Spaansche peper, in de oogen druppelen, de huid kerven en met bijtende stoffen insmeren; groote hoeveelheden alcohol achter elkaar inzwelgen.

Op het onverwachts wordt nu de gado vaardig over den leerling en veelal zal hij al onmiddellijk duidelijk spreken. Als regel heeft de leerling verzocht om een bepaalden gado, doch het kan zijn, dat zich niet deze, doch een andere in hem manifesteert; men zegt dan, dat l.g. gado meer van den betrokkene houdt. Ze zeggen dan: „hadden we dat geweten, dan hadden we dadelijk begonnen met de bepaalde voor dezen gado passende kruiden".

Gedurende de oefenperiode wordt op gezette tijden (waarbij men ook let op de maanstanden) een gado-dans met de trom (apienti) gehouden, waartoe de obiaman's in den omtrek worden uitgenoodigd. Als regel zijn meerdere leerlingen tegelijk in opleiding en vaak gebeurt het dat terwijl de leerling zit te kijken naar het dansen van de obiaman's en van het (niet door een gado bezeten) volk, of mededanst, de gado ineens vaardig over hem wordt.

$\mathrm{Nu}$ gebeurt het vaak, dat iemand die er niets mede te maken heeft en thuis in zijn hangmat ligt, of langs het feest gaat, bevangen wordt door een gado, als een bezetene naar het dansterrein rent, begint te dansen en Kromanti te spreken. Bij zulke spontane uitingen is een gado van bijzondere macht in den betrokkene gevaren en allen aanbidden dezen en knielen voor den danser. Voorbeeld: men leidt een jongen op, opdat een Djibri (tijgergeest) in hem zal treden. Bij den gadodans wordt een familielid plotseling bezield door den geest 
van de Djadja (de tijgerkat die, omdat ze met beide voorpooten de prooi kan grijpen, geldt als oudere broeder van den tijger). Dit acht men dan een bijzondere gunst of zegen die over die familie is gekomen.

Niet alleen bij den volledigen gado-dans wordt de apienti bespeeld; ook als men den candidaten een penitentie of dgl. doet ondergaan (wat geschiedt door obiaman's over welke hun gado vaardig is geworden; die menschen doen het niet, doch hun gado's zijn het die eigenlijk handelen) wordt de apienti bespeeld; deze is onmisbaar; de goden wenschen dat. Bepaalde formules worden erbij uitgesproken door middel van de tromtaal.

Een man die een der Kromanti-gado's in zich heeft, kan alle Kromanti-gado's in anderen zetten; desgelijks iemand die een der Dahome-gado's heeft of een der Loango-gado's. De Djoeka's zijn de dienaren van de Kromanti-goden. De opleiding tot obiaman kost den betrokkene veel geld; hij moet dikwijls -veel alcohol schenken en ten slotte zijn leermeester geschenken en geld geven.

Vrouwen hebben wel vaak een gado, doch treden nooit op als priesteres van dien gado, evenmin als ooit een vrouw een offer plengt voor de Granjorka's; ze kan er alleen bij staan en met de anderen mede in de handen klappen. [Sp 40 meldt: Zeer onzedelijk gaat het toe bij die afdeeling der afgoderij, waarin vrouwen de hoofdrol spelen. Dance 77 makkt melding van sexueele uitspattingen bij bezetenheid door de Minje Mamma, watergeest, bij de kustbevolking van Britsch Guyana. Zie echter § 53].

$\mathrm{Om}$ aan te duiden, dat iemand over magische kracht beschikt, gebruikt men wel het woord „rijp”. [Volgens Ho II 264 waren de Boschnegers van meening, dat de dienstbare Negers verstandiger of beschaafder waren dan zij zelve, wat ze uitdrukten door moro lepi, rijper, doch wellicht werd bedoeld ,rijper in tooverkracht”, vgl. $2 \mathrm{H}$ 55]. Een tapoe (amulet, § 59) heeft slechts de kracht om wist (toovenarij) af te weren, als de obiaman die de tapoe vervaardigde, rijper (moro lipi) is dan de wisiman.

Een Saramakkaner, levende bij de Bonni's, deed zeer veel moeite om aan een gado te komen. Hij heeft er zich veel kosten voor getroost en ontberingen en lichamelijke pijn doorstaan, doch hoewel de kuur jaren is voortgezet, is de gado nooit vaardig over hem geworden. Bij de seances, waarbij meerdere obiaman's bezig waren hem te bewerken, meenden deze telkens op den goeden weg te zijn en stelden hem dan de vraag „Laleni (zijn naam), ben jij nog hier?” Tot hun 
verbazing was dan het antwoord ,,ja, ik ben nog hier, ik voel precies hetzelfde als toen ik hier kwam zitten”; „mi de nanga krien aai”, ik ben nog met heldere oogen, d.w.z. mijn gewone bewustzijn is geheel intact. Wanneer de bewerking wél gelukt, is het teeken dat de gado nadert, dat de betrokkene als men hem iets vraagt, verwarde antwoorden gaat geven en droomerig wordt.

Als een obiaman hulp zal verleenen bij een ziekte ( $(81)$, dan roept hij zijn gado op, of laat dien door een ouderen obiaman oproepen.

In 1.g. geval noemt de oudere den naam van den gado en zegt „grantanji, kong na na bija hedde" (alsjeblief, kom in het hoofd van den kameraad). Degene wiens gado wordt opgeroepen, zit stil te kijken; geleidelijk verstart zijn blik en plotseling springt hij op, maakt sprongen en spreekt Kromanti; naar Boschnegeropvatting is het de over hem vaardig geworden gado, die spreekt. [d. G.: de Kromantigadoe komt in je hoofd].

Als de obiaman zelf zijn gado wil oproepen, dan zondert hij zich af in een hutje, de obia-hoso of obia-masanga, waar hij zich besmeert met uitgeperst sap van verschillende kruiden en met de onmisbare pimba. Hij neemt den rammelaar en begint te rammelen en zingt obia-liederen (gado-siengi, zie ook 1G 57) waarin hij den gado hulp vraagt en zijn devotie betuigt en zijn hulpeloosheid; hij zegt den gado, dat hij zich machteloos voelt en dus de hulp van den gado onmisbaar is.

$\mathrm{Na}$ korter of langer tijd wordt de gado vaardig over hem en uit zijn mond klinken woorden waarin de oorzaak der ziekte wordt medegedeeld en de middelen tot genezing worden aangegeven. Er staan eenige helpers bij, die luisteren wat hij zegt en die vervolgens, zoo noodig, helpen bij de behandeling van den patient. Het gebeurt vaak, dat de bezeten obiaman het bosch in rent en terugkomt met verschillende kruiden of plantenwortels of knollen (tajers) waaruit het geneesmiddel bereid moet worden. $\mathrm{Er}$ is een zeer bepaalde kruidenwetenschap, doch ik weet niet meer welke kruiden voor de verschillende gevallen gebruikt worden. [C 22: „Zeer dikwijls zijn de bij die gelegenheid opgegeven en vreemdsoortigste kruiden van gunstig gevolg geweest"].

Is de uitspraak van den gado, dat de ziekte een ingewikkelde oorzaak heeft, bijv. dat de patient ziek is geworden, omdat vele jaren geleden een oom van hem pikado (bloedschande) heeft gepleegd, dan moeten hieraan meerdere gado's te pas komen. Zijn er geen dragers van die gado's op het dorp aanwezig, dan worden ze van andere 
dorpen opgeroepen, waarvoor ze zich veelal goed laten betalen door de betrokken familieleden.

Het komt voor dat obiaman's wier gado vaardig over hen is geworden, bij elkaar zitten te beraadslagen over het geval. Plotseling rennen eenige der ouderen van hen, het bosch in, komen terug met kruiden, grijpen een van de jongeren die achterbleef, besmeren hem met de kruiden, pijnigen hem, bijv. door bijtende sappen in zijn oogen te druppelen en dan komt die jongere in een toestand waarbij ineens uit zijn mond het geheim klinkt, waarnaar men zocht. Men neemt aan, dat een oudere en wijzere gado, die doorgaans niet meer vaardig wordt over menschen, zich van den betrokkene bediend heeft om zich uit te spreken; deze spreekt ook met een stem als van een gezaghebbenden oudere.

Als straks de obiaman's weer tot het gewone bewustzijn zijn teruggekeerd, weten zij niet meer, wat zij gezegd hebben; daarom zijn er altijd een of meer luisteraars aanwezig.

Het komt voor, dat men meerdere keeren vergaderd heeft, zonder succes. Dan wordt er een gado-dans gehouden en het kan gebeuren, dat een der dansenden in de bezetenheid uitroept wat de oorzaak der ziekte is.

Voor verschillende ziekten zijn er verschillende gado's. Bijv. voor een vrouw in barensnood wordt de hulp van den Dinga-gado ingeroepen, die de kruiden aanwijst welke op het lichaam gesmeerd of gedronken moeten worden om de bevalling te bespoedigen. Dat die vrouw moeilijk bevalt, heeft zijn oorzaak in een fiofio of in een koenoe, als anderszins.

Of een man heeft onwetend een boom geveld, waaromheen abrasa, de moordenaarsliaan gekronkeld was. Dat brengt een onheil: ramp, ziekte of dood. Om de kwade werking op te heffen of te voorkomen, roept men een obiaman te hulp, bij voorkeur een die met een Djasofoe-gado verbonden is, doch als er zooeen niet te vinden is, dan kan ook een andere gado het doen.

Of een vrouw heeft een visioen, dat in een steen op het pad naar haar kostgrond een geest huist. Zij vraagt aan obiaman's om dat te onderzoeken en deze bevestigen het. Er worden nu bij dien steen vlaggetjes in den grond gestoken en het wordt een offerplaats; voor de vrouw is het de beschermgeest van haar kostgrond. Zou iemand bij zoo'n plaats, ook al weet hij het niet, zijn behoefte doen, dan zal hem ziekte of onheil treffen, dat weer op de gewone wijze moet worden opgeheven. 
Men neemt aan, dat degene over wien een gado vaardig is, met dien gado in gemeenschap is en hem ook aanschouwt. Doch als de gado hem (of haar) weer loslaat en hij in het gewone bewustzijn is teruggekeerd, weet hij niets te vertellen van wat hij heeft doorge. maakt. De gado heeft zich openbaar gemaakt door hetgeen de bezetene sprak en degenen die toeluisteren vernemen aldus wat de gado openbaart.

Ik heb het eens medegemaakt, dat een man in bezetenheid vertelde van iets dat hem overkomen was. Toen hij weer bijkwam en men hem zeide wat hij had verteld, zeide hij ,het is niet gebeurd, de gado heeft gelogen". Twee dagen later kwam hij met zijn broer uit het bosch en meldde dat wat hij in de extase had gesproken, hem thans werkelijk was overkomen. De gebeurtenis was, dat ze een geest zagen, die plotseling verdween; ze wilden terugkeeren en zagen dien geest ten tweeden male; daarop zagen ze een tijger (of slang) en zeiden ,nu heeft de geest zich gemanifesteerd in iets gevaarlijks en moeten wij weggaan". Jaren later werd de gado van dien man niet meer vaardig over hem, doch een andere geest werd vaardig over hem (maakte hem bezeten), die zich bekend maakte als de vroeger ontmoette geest, welke altijd zijn beschermgeest was geweest.

\section{$\S 37$. Priesters der lagere goden. Bezetenheid (vervolg).}

Een voorbeeld hoe een man door een gado bevangen, willoos werktuig is van bijzondere krachten of machten, is het volgende:

Op een avond aan de Gonini-monding, omstreeks 1912, had ik een aantal Djoeka's bij mij, waaronder twee jonge mannen, Fikki en Tani, en een oudere, Blaka hati kouroe. Tani was leerling-obiaman en juist in het tijdperk dat de gado vaardig over hem zou worden. Fikki spotte daarmede; in enkele woorden Kromanti (de voertaal van den gado) bespotte hij den gado die in Tani zat. De oudere waarschuwde daartegen, en daar ik geen Kromanti verstond, vroeg ik hem, wat het te beteekenen had, waarop hij mij vertelde, dat Fikki bezig was den gado van Tani te beleedigen en te sarren.

Op hetzelfde oogenblik sprong Tani, die rustig had liggen luisteren en lachen, uit zijn hangmat (het was 10 uur 's avonds) met een helsch kabaal en maakte allerlei luchtsprongen. Het hutje waarin de twee jongens zich bevonden, was 6 à 7 meter van mijn hut; in twee sprongen doorschreed hij dien afstand en stond voor mijn hut, met verstard gezicht en uitpuilende oogen, aldoor opgewonden oreerend in het Kromanti.

D1. 99. 
In mijn hut was een vlammend vuur, waarop ik juist drinkwater kookte. Tani ging er naartoe, greep den pot en zwaaide dien zoo, dat het kokend water voor een deel over zijn lichaam liep, schopte den drievoet waarop de pot rustte weg en ging in het vuur dansen tot dit nagenoeg uit was, kwam daarop terug en ging door met oreeren, doch minder opgewonden.

Toen was het voor Blaka hati kouroe de tijd om in te grijpen. Tot dusver had hij mij gerustgesteld, zeggend ,laat $u$ hem zijn gang maar gaan, straks wordt hij kalmer". Hij ging naar Tani, die volgens hem thans een gado was en door wien de gado sprak, hurkte aan diens voeten en sprak Kromanti tot hem. Men kon zien hoe Tani hoe langer hoe kalmer werd en zijn gelaat zich ontspande. Ineens, met een geweldigen roep (als iemand die uit den slaap ontwaakt), herkreeg hij het gewone bewustzijn en was verwonderd, dat hij zich in de hut van een ander bevond. De oudere sprak daarop ,gran tanji gado", heb dank, godheid.

Aan voeten en lichaam van Tani was niets te zien van de aanraking met het kokend water en het vuur; meermalen is zooiets geconstateerd.

Tweede voorbeeld: Er was in 1920 te Pikienkondre nabij. Drietabbetje een brokodéi (\$ 84). Het was laat in den avond en daar ik vanwege de feestdrukte niet in slaap kon komen, ging ik naar het terrein van den dans, bij de fragatiki ( $\$ 55)$. Nadat ik er een poos zat, hoorde ik op eenigen afstand een helsch lawaai, Kromanti zangen en uitroepen: een gado was vaardig geworden over een jongen man, Bajoeko genaamd. Niet lang was Bajoeko aan den gang, of een tweede, zijn neef Koejoeko, viel in. Ik vond het interessant en wilde ernaartoe gaan, toen een oudere, Gagoe (momenteel Granfiskari van de Tapanahoni) tot mij zeide: ,neen mijnheer blijft $\mathrm{u}$ hier wachten, zij moeten toch naar de fragatiki komen, het zijn nieuwe gado's die vaardig geworden zijn over menschen en zich verstaanbaar kunnen maken" (dem tongo broko, hun tong is gebroken, d.w.z. zij kunnen zich in menschelijke taal verstaanbaar maken). Aangeteekend zij, dat maanden lang zulke lieden onverstaanbare geluiden uiten, tot op eenmaal ze zich uitdrukken in zuiver Kromanti.

Het gaan naar de fragatiki beteekent zooveel, als hun opwachting maken bij de Granjorka's. Dit gebeurde dan ook en in allerlei zwierige dansen gingen beide jongens rond de fragatiki, aldoor zwaaiend met de krontiki ( $(54)$.

Het dorp was gebouwd op zeer geaccidenteerd terrein en op een 
10 meter afstand van de fragatiki ging de grond vrij steil 3 à 5 meter naar beneden over ruwe steenen en daar was een vuilnisbelt met vele gebroken flesschen en potten; een gewoon mensch zou ook bij dag er moeilijk doorheen kunnen gaan zonder zich te kwetsen. Na een poos om de fragatiki gedanst te hebben, zetten de twee jongelieden hun dans voort tot vlak voor dien vuilnisbelt en met een sprong, zooals een visch uit het water schiet en met den kop naar beneden weer onderduikt, verdween de eene met het hoofd naar beneden in de diepte en de ander volgde vlak achter hem.

Beiden verdwenen in het bosch, terwijl het stikdonker was; men kon ze luide Kromanti liederen hooren zingen en formules hooren uitspreken, en de stemmen verwijderden zich hoe langer hoe verder.

De ouderen waren verrukt over de prestaties van de gado's en den leermeester die de gado's bij deze jongens had ingezet prees men als een meester in zijn vak. Intusschen duurde het zingen en lawaai maken van de twee jongens in het bosch nog voort, maar daar het reeds lang na middernacht was, verliet ik het feestterrein en zocht mijn hangmat op.

Den volgenden ochtend, toen ik in de vroegte voor mijn huis zat, trokken de beide jongens met hun geweren en jachttasschen er op uit. Ik hield ze staande met een praatje over hetgeen den afgeloopen nacht was gebeurd. ,Ja, dat hadden ze ook van de ouderen reeds gehoord; zelve wisten ze het niet. Bajoeko lag in zijn hangmat, toen de gado eensklaps en zonder eenige voorafgaande waarschuwing, vaardig over hem werd. Koejoeko, die lag te slapen in een andere hut, sprong op van het lawaai van Bajoeko en het bleek, dat ook hij door den gado bevangen was".

Van eenige vermoeidheid of letsel door den sprong door de vuilnisbelt was geen sprake. - Het gebeurt ook wel eens, dat een zich kwetst; men zegt dan, dat die persoon gezondigd had tegen den gado. Ik teeken hierbij aan, dat ik meerdere keeren heb bijgewoond dat iemand slechts veinsde, dat de gado in hem gevaren was. Dit gebeurt vaak met drankzuchtigen, die op een borrel belust, het doen voorkomen of hun gado een borrel eischt. Zooals men weet, is de opvatting der Boschnegers, dat aan de vorderingen van een gado voldaan moet worden.

[C 22 meldde: Meest alle boschnegers hebben Wentie of opwekkingen der afrikaansche afgodische dansrazernij, dat men moet zien, om het te kunnen gelooven en begrijpen. $Z_{\mathrm{ij}}$ kunnen dikwijls wel vijf minuten lang in een sterk vuur ongekleed en barrevoets dansen, zon- 
der zich in het minste te branden, en zonder dat eenig teeken van zenging aan hen te zien is].

d. G., dagboek afreis Tapanahoni per Djoeka-boot, 23 November 1904:

In val Agidisiengi wordt de stuurman van een boot, Apouwisi, door een sipari (rog) in den voet gestoken. We stoppen, men zuigt het uit en geeft een sneetje met een scheermes in den voet; in beide wonden wordt nu een zwart poeder gewreven, dat ze in een fleschje irı hun trommel bij zich hebben. Inwendig (bij gebrek aan lemmetjes) citroenzuur uit mijn medicijnkist. Dan gaan we door. Sully (een der passagiers) stuurt de boot, daar de zieke nu veel pijn heeft. Hij steunt en begint dan gadoe tongo, d.i. kromanti, te praten: ,hei, hei, hei, tangka, tangka, pioka, pioka, plawa (4X), tangka, koto (2X), héi, héi, plasji $(5 \times)$, tloki $(5 \times)$, kille $(5 \times)$, plawa, pioka, enz." Wat verder stoppen we, en de Djoeka's gaan luisteren hoe de geest spreekt en klappen als blijk van instemming zachtkens in de handen. Volgens hen vertelt de geest: ,de baas (degene die A.'s obia maakte) is ziek, en de shia straft A. wijil deze naar de benedenrivier gaat inplaats van zijn baas (te Mainsi) op te zoeken [vgl. 1P 162 geestdraad tusschen het voorwerp en den obiaman die den geest daarin heeft gebracht].

d. G., 3 Augustus 1907 te Drietabbetje groot winti-dansfeest of gadoe-pree (pree = spel, feest), zie 1G 45-49.

d. G., dagboek opreis Marowijne, 21 Juni 1937 te Amekan- kondre (Paramakkaner Boschnegers):

Als alles stil is, zoo omtrent 8 à 9 uur, hooren we in het dorp stootend gesteun, afgewisseld door snel spreken; gaan er heen. Alle huizen roerloos in het maanlicht. Op het geluid af. Komen aan een open hut. Daar zit op een bankje een man, gezicht en lichaam, beenen en armen geheel wit van de pimba; voor hem een klein half kalebasje met pimba (dat ze op een plek uit den grond opdelven), in de rechterhand een rammelaar waarmee hij voortdurend schudt. Erbij staan twee jonge mannen die luisteren naar wat hij spreekt en zoo nu en dan antwoorden ,ja”, of de een zegt tot den ander ,joe $j e ́$ ?" (hoor je het?). Afwisselend laat de man eenige diepe steungeluiden, als gegrom, hooren en dan weder praat hij vrij snel; enkele woorden lijken Negerengelsch. De twee bijstaanders die ons gereedelijk te woord staan, zeggen, dat de man kromanti spreekt. Hij is een obiaman, een ,boesi datra” (bosch-dokter), zoo zeggen ze; Kromanti-obia is over hem, spreekt door zijn mond. Hij geeft advies over een ziek kind, en de toehoorders vernemen dat een lang overleden 
persoon dat kind ziek maakt en dat men moet ,poer watra, poer sópi" (water, rum, uitstorten) en met bepaalde kruiden moet wasschen. De obiaman heeft zich in dien toestand gebracht door kruiden van het bosch en door de obia aan te roepen. Als het overdag was, dan zou hij ook de obia-armringen of dgl. dragen. $\mathrm{Nu}$ en dan zingt men, naar het lijkt, een soort oproep, die daarna wegsterft.

$\mathrm{Na}$ een tijd (totaal zal hij een uur bezig zijn geweest) gaat het schudden van den rammelaar vlugger en wordt zwakker. De bijstaander zegt ,de winti laat hem los”. Dan valt zijn rammelaarhand slap neer. Hij ontwaakt als het ware, wrijft met een handdoek de pimba van zijn gelaat en lichaam en als we dan onzen electrischen fakkel laten gloeien, dan is het een gewone, iets oudere, Neger (Paramakkaner), die ons heel gewoon te woord staat op onze vragen.

De rammelaar bestaat uit een bolvormige kalebasschaal, ongeveer $15 \mathrm{cM}$ middellijn, waardoor een stok steekt, waarvan het bovengedeelte in een knik is gegroeid (vgl. § 54 kromtiki). De kalebas is van buiten met figuren in laag relief besneden en erin zitten, naar men zegt, bepaalde zaden.

26 Juni op de Djoeka-nederzetting Odoen aan de Lawa: Aan den rand van het dorp nabij den waterkant bevindt zich een platform op palen; van de leuning van het platform hangen franjes maripapalmblad af [§61]. Op het platform bevinden zich een emmer met water en een ijzeren pot met kruiden in water en er hangt een ijzeren kruik die als bel dienst doet. Eenige malen per dag begeeft een jonge man zich op het platform, doet de bel klinken ( $\$ 63$ ), wascht zich onder het uitspreken van woorden met de kruiden en besmeert zich daarna het lichaam met pimba, gemengd met water. Het is om de Kromantiobia te verwerven. Hij zal dit 3 maanden doen, dan bespeelt men overdag de apienti en komt de obia over hem. Daarna kan hij telkens als hij het noodig heeft de obia oproepen. Vervolgens behoeft men nog slechts zoo nu en dan, met tusschenpoos van eenige jaren, zich wederom met kruiden te wasschen. Niet iedereen heeft een obia.

27 Juni op de Lawa. Mijn stuurman begint omstreeks 12 uur af parelend (roeiend) plotseling met de daarbij behoorende stootende, uit de diepte komende stem, Kromanti te spreken, daarna overgaand in zacht zingen: zijn obia, die Kromanti is, bidt tot de godheid Grantata.

30 Juni. Een vrouw uit de stad woonde op de reis naar de bovenrivier bij, hoe een Boschneger-obiaman advies over ziekte gaf. De obiaman ging zitten; een ander ,poer watra" (stort water) voor zijn 
voeten en riep den gadoe van den obiaman aan. Toen begon de obiaman, die met voorovergebogen hoofd zat, te trillen en uitte plotseling een schreeuw: de gadoe was in hem vaardig. Daarop zette hij pemba voor de voeten van den obiaman en deze besmeerde zich met. pemba. Vervolgens groetten alle aanwezigen den gadoe door met den vinger te wijzen en de hand om dien vinger te draaien. $\mathrm{Nu}$ gaf de obiaman aanwijzingen. Men ging in het bosch om kruiden te halen, maakte een kruidenbad, bracht de zieke vrouw, die als dood was, buiten en besprenkelde haar. Eindelijk kwam de zieke bij en vroeg „hoe kom ik zoo nat?”.

SAR Om een Koma(n)tí-geest (Stadsnegers zeggen Kromanti; het is een winti) op te roepen, moet men door dien geest bezeten zijn, dien geest tot helper hebben. Wie dat verlangt, gaat bij een baas (leermeester-obiaman) die zelf zoo'n geest heeft. (Zie ook $1 \mathrm{H} 314$ vlg. en 2J 314 toezicht op een jongen man, of hij wel geschikt zai zijn). Het teeken van Komanti is wapenen: geweer, houwer, stok.

De leerling begint met 8 dagen een kruidenbad te nemen. Dan neemt de baas een houwer en begint te zingen en te dansen en ook de leerling gaat, terwijl hij nog bezig is het bad te nemen, dansen. Is hij klaar met baden, dan gaat het gezang door en de baas slaat hem met het scherp van een houwer; het wondt hem niet. Of de baas schiet met een geweer op den leerling; deze wordt niet gewond; den kogel (de hagel) vindt men terug in een bord met medicijnen (kruiden, welke, weet ik niet precies). Wie Kromanti bezit, kan ook in een doornbosch (awara-palmen) gaan of met vuur spelen, zonder dat het hem deert. Ik (mijn zegsman) heb dat alles gezien, behalve het schieten, waarvan ik alleen de voorbereidselen heb gezien (vgl. van Coll 553, 1H 338-340, 3J 89). De leerling is nu tegen alle gevaar beveiligd. Als later bijv. een tak op je valt, dan roep je ,hee Komanti” of ,he obia" en de tak valt terzijde. Of als iemand je met een houwer wil kappen, roep je dit en de houwer treft niet, of breekt.

De leerling betaalt den meester, bijv. met panji's (doek) en sopi (sterke drank). Nu kan hij zelf ook Komanti oproepen. Je moet oppassen hem nooit met geweer of houwer te bedreigen, dan krijg je zelf een ongeluk.

De baas danst nu en dan nog Komanti om te probeeren of de geest nog in hem zit; hij oefent, net als de militairen.

Iemand die Komanti danst, ziet, terwijl hij bezeten is, de geesten, maar hij kan er later niet van vertellen; het is onbewust.

Een Saramakkaner, in dienst bij de nederlandsche grensexpeditie 
1935, was op een ochtend onwel en koortsig. Kort na den middag begon hij plotseling buitenmenschelijke geluiden uit te stooten, smeet met voorwerpen, sloeg een flesch stuk en sloeg met zijn handen in de scherven. Daarna zakte het, na een siddering, plotseling en ging hij zich wasschen. Die bezetenheid heeft zich dikwijls herhaald en was zoo hinderlijk, dat men den man moest terugzenden.

STAD De volgende namen zijn of waren in gebruik: wat de bezetene beleeft winti (wind), mapokro (1P 170, Wu 2); de bezeten makende geest winti, winti-mama, afkodrai (afgoderij), $2 \mathrm{H} 58$ komfo; de drager van een of meer van die geesten wintiman, obiaman, sabiman (MK), bonoeman, obonoe (vrouwen ook wintimama, obiamama, watramama, $\mathrm{Wu} 288$, Benoit 25). Lockocman is meer iemand die er een beroep van maakt, met winti en toovermiddelen te werken; een „,slechte” lockoeman is al min of meer een wisiman ( $(48)$. Men zeide mij nog, dat de loekoeman (loekoe = zien) een soort waarzegger is; een loekoeman die een winti heeft, kijkt in een spiegel, ziet dan in je handen en kan je toekomst vertellen (zie ook $2 \mathrm{H} 56$ vlg.). Een bonoe zou volgens dien zegsman een z.g. dres-neger of dreesiman zijn (dreesi $=$ geneesmiddel, zie voorts $1 \mathrm{P} 181$ en Enc 275). Naar de berichten te oordeelen, berust het bedrijf van den loekoeman nog vrijwel geheel op de oude negermagie, doch heeft, wat deze lieden doen, weinig of geen waarde en men hoort zelfs van gewetenloos bedrog.

Iemand die zijn winti over zich heeft, noemt men wel toehedde soema (tweehoofdige mensch); er is dan n.l. een ander over hem, hij is niet meer zichzelf. Een goede winti duidt men ook aan met het woord ,geluk”, en het woord „bribi" (geloof) gebruikt men om een geest an te duiden (1P 172, 158, 2H 99). Het woord mapoper is volgens van Lier vermoedelijk geen negerengelsch woord; het wordt door de beter ontwikkeleden gebezigd als verzamelnaam voor al wat men onder afkodrai, winti, bakroe enz. verstaat; ,werken met mapopers" is werken met zulke bovennatuurlijke middelen voor eigen materieel voordeel.

Als iemand sterft, dan gaat diens winti over naar zijn kleinkin.1 (zie voorts $2 \mathrm{H} 68 \mathrm{vlg}$ ). Men kan ook een winti krijgen, als men bijv. in het bosch iets kapt en de winti die daarin was, je pakt. Wie een dagowee- of papa-slang doodde en door de „mama”, de moeder (geest) die de slang ,,bereed” (den drager van een winti noemt men hasi, paard) vervolgd wordt, verzoent die mama door het $1 \mathrm{P} 174$ vermelde gezang „Dagoewee, de kleine jongen (verm. ,ik”) verlangt 
de dagoewee. Moeder (geest) ik heb de slang weggeworpen (gedood), maar jou heb ik niet weggeworpen. Volgens 1P 171 en anderen houdt men de winti-dansen bij voorkeur onder een kankantri (Ceyba-boom) waarin de winti's bij voorkeur verblijven).

Kromanti-winti (van Afrika) komt al bij je vanaf dat je een klein kind bent. Je voelt op een winti-feest, dat de Kromanti-winti over je komt en dan vraag je eerst je akra. Want de akra ,moe gi passi", moet doortocht verleenen; de akra is de baas van alles. „Joe merki eng na joe skien", je bemerkt hem (den geest die over je wil komen) aan je lichaam.

(Stn I/90 vermeldt, uit 1743: kinderen worden op het graf van hun voorvader gebracht en deze geeft een uitspraak welken god het kind zal hebben).

Als de geest zich merkbaar maakt, wanneer je naar de kerk gaat, dan weet je, dat hij je ziek zal maken, en dan ga je niet meer. Als je naar de kerk wilt, dan moet je, als de winti in je hoofd komt, hem vragen. Als hij het goed vindt, dan mag je naar de kerk gaan (vgl. ook 1P 169-170).

Mijn zegsman heeft ook winti gedanst; ,,je verstand verlaat je dan". Hij heeft door het vuur zien dansen en een bezetene in een doornpalm zien klimmen.

Een Arowak-Indiaan zeide mij, dat de indiaansche piai (medicijnman) zooals die vroeger was, sterker is dan een wintiman. De piai ziet de geesten, de Neger ziet ze niet, ook niet in den droom. De piai kan de djodjo of de akra van iemand naar zich toe trekken, terwijl een neger-wisiman naar de plaats van de djodjo moet gaan.

Van Lier vertelt: Ik was in 1910 bij het balatawinnen in een magazijn aan de Gonini-monding en gaf op een avond een feestje aan mijn arbeiders. Van naburige ontginners waren ook arbeiders op bezoek gekomen, zoodat er plaatsen te kort waren voor het spannen der hangmatten.

Een der Stadsnegers, Griffit, had zijn hangmat gespannen heelemaal tegen het dak van het magazijn op een hoogte van tenminste drie meter. Het feest was nog niet geëindigd, toen Griffit zijn hangmat opzocht. Ineens hoorden wij hem geluiden uitstooten, die den indruk maakten als van een beest afkomstig te zijn, en het duurde niet lang, of Griffit tuimelde uit de hangmat en kwam met zijn borst terecht op den stomp van een afgekapten boom, met zoo'n geweldigen smak, dat ik en anderen het voor zeker hielden, dat hij voor dood lag. 
Doch Griffit had zoogenaamde dagowee-winti, d.i. de geest van de dagowee-slang (tapijtslang of papaslang) was in hem gevaren. Met de kronkelingen van een dagoweeslang bewoog hij zich over den grond, door den modder over het erf. En nu gebeurde er iets merkwaardigs. Griffit was een kleine zwakke man, terwijl Zeeburg, een ander arbeider, een robuste en zeer sterke kerel was. Men was met het geval verlegen, niemand wist raad hoe de winti te bezweren, terwijl Griffit maar door den modder bleef kruipen. Zeeburg, meer voor bluf dan werkelijkheid, gaf zich uit voor wintibezweerder, ging naar Griffit toe, hurkte bij hem en begon hem op den schouder klop. pende aan te spreken met „dagowee, na mi dia” (dagowee, ik ben hier) ,joe basi Fiki” (je baas Fikki). Wij zagen nu, dat Griffit ineens zijn arm sloeg om den bij hem gehurkten Zeeburg, hem om zijn middel vatte en den sterken man voortsleepte, die, met alle macht zich werend, zich niet uit dien greep los kon maken en zelfs ademnood kreeg. Ook de andere arbeiders konden hem niet los krijgen.

Toen heeft een oude Neger, Pa'Mari, gevraagd, of iemand een stuk lala-krabas (rauwe kalebas, een reeds uitgeholde maar nog niet gebruikte kalebas) had. Een der arbeiders had zoo'n nieuwe kalebas bij zich en de oude gelastte toen, dat men daarmede water zoude halen uit een nabijzijnde kreek. Daarop nam hij de gevulde kalebasschaal in de handen en wierp Griffit het water in het gezicht, tot drie maal achtereen; de derde maal was de kalebas leeg en op zijn voeten stampende riep de oude drie maal ,dagowee, mi taki loes ing”, dagowee, ik zeg je, laat hem los). Griffit liet los, zijne armen vielen slap neer; hij stond op, wreef zijn oogen, ging zich verkleeden en kroop weer in zijn hangmat. Zeeburg moest naar zijn hangmat gedragen worden, nadat zijn kameraden hem een bad hadden gegeven.

Den volgenden morgen, toen ik vóór zes uur naar de rivier ging om een bad te nemen, kwam juist Griffit uit het bad. Ik vroeg hem, hoe hij zich voelde, en hij antwoordde ,gezond, mijnheer”. Later op den dag liet ik Griffit bij mij komen en wenschte van hem bijzonderheden te weten betreffende zijn winti. Hij verklaarde toen aan mij, dat hij op de plantage Auka thuisbehoorde, waar, evenals bij de Boschnegers, zoowat iedereen een winti heeft; wie daar niet een aangeboren winti heeft, laat er zich een inzetten. Zoo is voor hem een winti ingezet. Hij koos de dagowee, doch toen deze voor de eerste maal vaardig werd over hem, had de winti geopenbaard dat hij, Griffit, nooit jenever mocht drinken. Hij was den vorigen avond echter uit gulzigheid te buiten gegaan en had mede van den rond- 
gedeelden jenever geproefd en wel vrij veel. - Griffit bleef gezond en frisch, terwijl Zeeburg drie dagen lang zijn hangmat moest houden!

Van Lier heeft ook bijgewoond hoe een Chinees uit Banka (Ned. Oost-Indië), die nog geen maand in Suriname was en werkzaam bij de Gouvernements Mijnexploratie op Awara Soela (boven-Lawa) een winti-bezetenheid kreeg, precies als een surinaamsche Neger.

1P 178-179 meldt, dat alle winti's het vermogen hebben, de toekomst te voorspellen en in het verleden te lezen, en zie voorts Inl. (2).

Dikwijls zijn Blanken ooggetuige geweest van deze bezetenheid. DJOEKA van Lier a.v., C 22, 1G 45-49; SAR verscheidene Herrnhutter zendelingen, zie Stn, 3J 86-90, 1H 228-247, 322-343; STAD 2H 79-82, 86-99.

\section{$\S 38$. Kandoe.}

Iedere Boschneger kan zich vrijwaren van diefstal of molest wanneer hij zijn woning of kostgrond verlaat, door het plaatsen van een kandoe. De kandoe bestaat uit een of meer voorwerpen, zooals een stuk van een versleten matapi (kassavepers), een oude bezem, een gebroken kom, een gebroken parel (pagaaier) enz. en dit, ter plaatse neerlegd of opgehangen, heeft afweerkracht; een persoon die de kandoe veronachtzaamt, zal ziek worden of door een ongeluk getroffen worden. Er zijn talrijke soorten van kandoe's, die meer of minder gevaarlijk zijn en verschillende ziekte of soort van ongeluk teweeg kunnen brengen.

Een voorbeeld. Een man wil zijn vruchtdragenden manja-boom tegen dieven beschermen. Hij neemt bijv. een oude kalebas, een stuk van een versleten jachttasch, wat kokosvezels, scherven van een gebroken aarden kom, een stuk van een oud kapmes, totaal vijf of zes dingen, en legt dit alles op een hoopje op een goed zichtbare plaats aan den voet van den boom. Men neemt aan, dat de akra van dien man in die voorwerpen huist (zonder dat daarom de akra den man zelf verlaat). In de soort van voorwerpen en de manier van nederleggen en de woorden die daarbij geuit worden, ligt besloten de aard der ziekte of ramp die den overtreder zal treffen.

De straf kan bijv. zijn zware pijn in de zijde, constipatie waardoor bij het ontlasten de anus scheurt, pijn aan het scheenbeen. Of het kan zijn, dat de delinquent ondanks zichzelve gaat werken voor den benadeelde; dit is vooral de werking van een kandoe tegen diefstal van landbouwproducten. Of hij wordt vergeetachtig, of een wisi-wasi- 
man (onbenullige) of hij kan de plek waar de kandoe is gesteld, niet verlaten, tot de eigenaar van het goed hem daar aantreft.

De kandoe kan opgeheven worden, behalve door dengene die haar gesteld heeft, ook door diens bloedverwanten, onverschillig man of vrouw, wanneer zij dezelfde boassi-kina ( $(13)$ hebben.

BONNI Volgens Axwijk, evangelist te Cottica, bestaan er bij de Bonni's twee sterke kandoe's: 1. een oude schop, gehangen vóór het huis of voor den aanplant of dwars over een boot; 2 . wit katoen tot reepen gescheurd, de reepen aan elkaar gebonden. Beide doen aan een doode denken en daarin ligt hun "kracht.

SAR Sta 261; soorten van kandoe, zie Schu 75, 76, 100 ; opheffen kandoc $1 \mathrm{H} 39$.

\section{§ 39. Moela.}

Een niet tot dezelfde boassi-kina behoorende persoon kan een kandoe opheffen, als hij daartoe volmacht heeft gekregen van dengene die de kandoe heeft gesteld, of van een ander die de macht heeft de kandoe op te heffen. Deze overdracht van bevoegdheid heet moela. De machtiger ,,geeft moela", de gemachtigde ",neemt moela".

Voorbeeld: Iemand komt op de rivier een Boschneger tegen, in wiens huis hij wil overnachten, of van wiens grondje hij een bos bananen wil hebben. De eigenaar geeft hem iets dat hij aan het lijf heeft, bijv. een stuk van zijn kamisa, of iets dat hij dagelijks gebruikt, bijv. zijn jachttasch. Hij geeft dit met gevouwen naar voren gestrekte handen aan den ander over, die het eveneens met gevouwen naar voren gestrekte handen ontvangt. De ontvanger doet nu de handen open, de gever blaast drie keer over het gegevene, waardoor wordt uitgedrukt, dat het uit zijn hart komt. De ontvanger slaat het drie keer tegen zijn voorhoofd om het in zijn geheugen te prenten en daarna drie keer tegen het hart, opdat hij de hooge waarde erkenne van de daad van het geven en de oprechtheid waarmede het gegeven is. De ontvanger kan nu de kandoe's wegnemen en wegwerpen, of tijdelijk terzijde leggen en het gegevene ervoor in de plaats leggen en daarmede is voor hem het kandoeverbod opgeheven. Het gegeven voorwerp moet daarna weder naar den eigenaar terug.

Moela heeft echter nog wijder strekking. Mocla wordt ook gegeven door dengene die een ander onderricht geeft in de bereiding van een obia, of iets dergelijks. De persoon die moela geeft, verklaart door de ceremonies die hij daarbij uitvoert, het onderricht met geheel zijn 
hart en naar beste weten te hebben gegeven. De persoon die moela ontvangt, prent het dan door de ceremonies welke hij verricht, in zijn hoofd en hart, opdat hij het niet weer vergeten zal en opdat bij ten allen tijde dankbaar zal zijn aan zijn leermeester.

Ook voor de overdracht van geestelijke macht door den een aan den ander, wordt moela toegepast, zoo ook als een verklaring wordt gedaan of een verslag uitgebracht, ten teeken dat degeen die het deed geheel ter goeder trouw was en dat degeen aan wien de verklaring gedaan werd, of het verslag werd uitgebracht, een en ander als echt aanvaardt.

\section{§ 40. Eed (d. G.).}

De Djoeka die den eed aan Grantata aflegt, dat hij geen wisi bedrijft ( $(19)$, moet daarbij een door een priester bereid mengsel van kruiden en water met pimba drinken. Wie dit doet met een onrein hart, zal aan de kwade gevolgen niet ontkomen. C 18 zegt, dat ,gebleken is, dat wie daarvan drinkt met een kloppend of ongerust hart, dikwijls direkte kenteekenen openbaart, zooals braking, opzwelling, bleekzucht enz”. (Onjuist lijkt mij Ko 401 „Eine Art von Blutsbrüderschaft kann durch Schwurtrunk mit dem Häuptling abgeschlossen werden, der hierdurch ein volles Erbrecht gewinnt und auch sonst den Blutsbruder fast ganz von seiner Familie loslöst").

Van de Bonni's meldt $\mathrm{Cr} 60$ : ,Tout individu soupçonné de meurtre est obligé de boire le poison d'épreuve. Nous savons par expérience que l'écorce servant à faire l'infusion présentée au criminel, et quelquefois au voyageur qu'on veut effrayer, ne possède aucune propriété toxique. Quand les accusés tombent en syncope, ce qui arrive, c'est qu'ils se sentent coupables". Zie voorts $\S 21$.

Ook bij de Saramakkaners bestaat een dergelijk gebruik, sooi genaamd (3J 84, 1H 204); , het ding (de geest) hetwelk de granman in den drank heeft gedaan, doet het werk"; $1 \mathrm{~J} 454$ meldt, hoe het gebruik van zoo'n drank slechts een laxeerende werking had. Stn II/ 2/266 (zie ook I/91-92) meldt, uit 1779, dat de drank bestaat uit water waarin het lijk van den vergiftigde of een ander lijk is gewasschen, een weinig aarde van het graf van den doode en verschillende zeer geheim gehouden kruiden; is degene die drinkt, de moordenaar, dan zal hij volgens het geloof, terstond opzwellen.

Een mengsel waarin bloed gemengd is, drinkt men, naar het schijnt, als menschen of groepen een verbond met elkaar sluiten; bloed van beide partijen wordt genomen en beide partijen drinken. 
Aldus de Djoeka's met de Nederlanders bij den vrede van 1760 en vervolgens bij de vernieuwing van het verdrag (Hartsinck II 800, Stedman I 93, 94, Benoit 61, 2 Kp 235); ook Djoeka's met de wegloopers onder Bonni (Wong 305), met Matoeari's in 1865 (Schneider 72), met den particulier Coster (C 3 vlg.) en met Trio-Indianen (2 Kp 369, 1G 215) - In 1937 vernam ik bij de Oajana-Indianen aan de Litani, dat vier hunner bloed hadden gedronken met den Granman der Bonni's Kwassi (Avinsai; foto van dezen 1F 148 eerste van 1., Ve 173 derde van 1.); sedert Avinsai gestorven was, achtten deze menschen zich ontheven van hun bond. Coudreau 251 vermeldt, dat bij den vrede tusschen Bonni's en Oajana's omstreeks 1815 , de eed door een drank bevestigd is, doch hij meldt niet dat er bloed in was gemengd. - Ook de Stadsnegers kennen het drinken van bloed (1P 181, 2H 63). - Eed zonder drank, zie 2H 85, 101.

- Nader meldt van Lier: Driengi broedoe is in den loop der tijden meer en meer in onbruik geraakt en komt nu slechts sporadisch voor. Het is een heilige daad, in den regel tusschen twee, in sommige gevallen tusschen meerdere personen, die daarmede een eeuwig verbond sluiten, hetzij van trouw aan elkander, hetzij voor wederkeerigen steun ter bereiking van een gemeenschappelijk doel. Schending van den bloedseed heeft altijd den dood van den schender ten gevolge. Voorheen kwam het nogal veel voor, dat echtparen „dee (verrichten) driengi broedoe”. Ik heb in de Tapanahoni een geval medegemaakt waarbij een jongeman plotseling stierf en het orakel (de heilige bundel) verklaarde, dat de doodsoorzaak was, het schenden van den bloedseed tusschen hem en zijn vrouw. Het driengi broedoe tusschen echtparen is in vele $l o$ 's (ik weet niet, of het voor den geheelen stam geldt) streng verboden en overtreding wordt zwaar gestraft. De gedachtengang daarbij is, dat, waar deze eed onverbrekelijk is en de schending daarvan den dood ten gevolge heeft, er voor lichtzinnigheid ten deze, gewaakt moet worden.

\section{$\S 41$. Vervloeken.}

Vervloeken of zichzelf verwenschen, komt veel voor bij de Djoeka's. Om er kracht aan bij te zetten, kleedt men zich naakt uit, gaat op den grond zitten, beweegt zich, steunende op de handen, voort, waarbij het achterste over den grond sleept (srépi gogó) en spreekt daarbij de vervloeking uit. Het geldt als een doodzonde tegen Grantata. 
Minder erg is fom anoe na dotti, met de hand op den grond slaan, of fom tiki na dotti, met een stok op den grond slaan.

De grond heeft kracht, omdat daaruit alle leven is voortgesproten en daarin alle leven ook weer verdwijnt; de grondgeest zal kracht bijzetten aan de bedoeling.

Zie voorts $\S 19$ en Stn II/2/276 opheffen der vervloeking.

\section{$\S 42$. Lobi dotti.}

Voorbeeld: Iemand vertelt ,die boot is zoo vol geladen, dat er in de eerste socla (stroomversnelling) een ongeluk zal gebeuren". Een ander roept uit ,lobi dotti na joe moffo", wrijf grond op je mond. Of hij schrikt zelf van wat hij gezegd heeft.

Hij raapt nu wat aarde op en wrijft die op zijn mond, waarmede, wat hij gezegd heeft, symbolisch begraven, d.i. geneutraliseerd is.

\section{§ 43. Ogri ai (het booze oog).}

Iemand kijkt uit liefde of met nijd of dgl. een kind aan. Als nu het kind ziek wordt, dan meent men, dat de jorka (?) van dengene die aankeek, de jorka van het kind overheerscht. Ogri ai is niet iets dat aan een bepaalden persoon eigen is.

J. E. Loth 345 vermeldt: Men behoedt zich tegen ogri ai, door met den duim naast de oogen een ander oog van witte klei te teekenen, welk teeken men atokro noemt.

STAD Zie 1P 167, 2H 42-43.

\section{§ 44. Soema-moffo.}

Wordt de oorzaak van een ongeval (of ziekte?) onderzocht, dan is in negen van de tien gevallen de uitkomst, dat wisi de oorzaak was. Het ééne geval van de tien is dan dat hetwelk veroorzaakt werd door soema-moffo (het door benijders bebabbelen) of door misi-akra (tekortkoming tegenover zijn akra) enz.

\section{$\S 45$. Magische invloed van de vrouw.}

Als een man voor een schotwond behandeld wordt, mogen de dokter (obiaman) en de verpleger gedurende dien tijd geen omgang met een vrouw hebben. Er mag in het geheel geen vrouw bij den 
gewonde komen en zijn eten mag niet door een vrouw bereid zijn. Andere mannen, dan dokter en verpleger mogen niet bij hem komen, daar er nooit zekerheid is, dat deze niet geslachtsgemeenschap met een vrouw hebben gehad. Is het noodzakelijk, dat de zieke met een anderen man spreekt, dan komt die voor zijn hut staan, de dokter komt met een speciaal daarvoor bereid kruidenbad, en onder het uitspreken van een formule in het Kromanti, besprenkelt de dokter de voeten van den bezoeker (die op een matje is gaan staan); eerst daarna mag de bezoeker binnengaan.

Soortgelijke voorzorgen neemt men in acht bij de opleiding voor obiaman (§ 36), bij het vernieuwen van de immuniteit ( $(57)$, en bij vischvergift $(\S 60)$.

Als een vrouw menstrueert, mag zij niet in haar huis blijven, omdat daardoor de obia's van haar man bedorven zullen worden en zijn immuniteit geneutraliseerd zou worden. Op alle Boschnegerdorpen zijn daarom aan den boschrand huisjes opgezet, z.g. moen-hoso (maan-huis) of takroe-hoso (kwaad huis), waar de vrouw deze periode doorbrengt. $\mathrm{Zij}$ mag gedurende dien tijd niet in haar eigen of in een ander huis komen. Potten en pannen die zij gebruikt, worden afzonderlijk bewaard. Eten, daarin bereid of opgediend, mag nooit door een man gebruikt worden, ook al zou dat geschieden op een tijdstip, dat de vrouw niet meer menstrueert.

Als een Djoekavrouw op reis overvallen wordt door de menstruatie, is zij verplicht daarvan oogenblikkelijk kennis te geven aan den bestuurder van de boot, die dan terstond naar den oever stuurt. Is hij een obiaman, dan zal de vrouw niet meer in die boot mogen komen. Er wordt voor haar een afdakje an den oever gebouwd; de mannen gaan op een heelen afstand voor zichzelve een onderdak bouwen en men wacht af, tot de vrouw weer rein is, of, tot er een boot voorbijvaart waarin geen obiaman aanwezig is, en die aan de vrouw passage kan verleenen. Dit passage verleenen is verplichtend tusschen menschen van dezelfde $l o$. Menschen van andere $l o$ 's doen het, met het oog op wederdienst. Wie weigert, veroorzaakt, dat menschen van zijn lo ook niet door menschen van de andere $l o$ in zulke gevallen geholpen zullen worden.

Deze zaak is van zoo ernstigen aard, dat er een zware straf staat op het verzwijgen, door een vrouw, dat ze menstrueerend is (a kibri doro, ze heeft het naar buiten gaan verzwegen). Men beweert, dat in oude tijden bij een ernstig geval zelfs de doodstraf werd toegepast. - Ondanks de straf, komt het toch vaak voor, dat vrouwen 
het verzwijgen. De Djoeka's vatten dit op als een ziekelijk verschijnsel; zoo iemand wordt dan niet meer gestraft, doch uit de gemeenschap gestooten; ze leeft nog alleen van de gunsten van haar familieleden.

Ieder heeft het recht en is verplicht, bij het ontdekken van een verzwegen menstruatie, dit te melden, wegens de ernstige gevolgen die zulk verzwijgen kan hebben.

Een menstrueerende vrouw mag met niets in aanraking komen; brengt iemand haar iets, dan zet deze het op den grond, reikt het haar niet over.

Een werkelijke maagd, kwejoeman genaamd ( $\$ 75)$, geldt als gelukaanbrengend. Gaat de Granman op reis, dan zijn er bij het reisgezelschap tenminste drie dergelijke maagden.

SAR Tijdens de menstruatie blijft een vrouw afgezonderd, bereidt geen eten voor anderen en komt niet bij menschen, want dat zou de kracht uit de obia's trekken. $2 \mathrm{H}$ 522-523 Een vrouw mag geen trom aanraken of bespelen..

STAD Zie 2H 73.

\section{$\S 46$. Magische invloed van. Blanken.}

d. G. Toen het voedingstransport der grenscommissie in 1937 in Djoeka-booten de Lawa opvoer, bracht men op verzoek van den Djoeka die de leider van het bootsvolk was, een bezoek bij den ouden Samalobbi, zoon van wijlen Apatoe, den metgezel van Crevaux, en van een zuster van den kort geleden gestorven Granman der Bonni's Avinsai (door de Oajana-Indianen Kwassi genoemd) en die na Avinsai's dood tijdelijk het granmanschap waarnam. De leider der Djoeka-bootslieden vroeg aan S. of er op de bovenrivier nog op kina's te letten is. S. antwoordde: sedert zich creolen aan de rivier

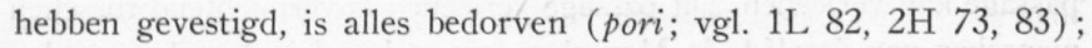
de gado is ,naar zijn plaats teruggegaan” (d.w.z. naar het geestengebied). Alleen moet men op de bovenrivier geen pot in de rivier spoelen en geen ingewand van wild in de rivier werpen ${ }^{1}$ ).

SAR Te Dahomey zijn vele obia's en ook beelden van oude menschen; als men een arm of been gebroken heeft, dan kan men daar bij een kruidenbehandeling na acht dagen reeds genezen zijn. Men laat er de Blanken niet toe. Zie ook Sta 668, 1H 171-172, 195, 252,

1) Misschien is dit een van Indianen overgenomen geloof. 
1J 456-457. 3J 127 vermeldt: De Blanke op zich zelf is een wezen, waarvan altijd gevaar voor den Boschneger uitgaat.

\section{§ 47. Azéman (vampier).}

Azeman of Ase kan als geest worden uitgezonden door een wisiman, doch meestal heeft de Azema woonplaats in het lichaam van een wisiman, die dan Azema(n) wordt genoemd. De Azema zuigt het bloed van een mensch (man of vrouw, doch het meest bij vrouwen) uit, wat zich merkbaar maakt aan vermagering en lusteloosheid.

De obiaman kan, als de gado vaardig over hem is geworden (in zijn hoofd is getreden) aanwijzen of de Azema in een persoon huist en wie dat is. Om een Azema te verdrijven, offert men aan de goden en Granjorka's, of de obiaman tracht het slachtoffer te beschermen door kruidenbaden en smeersels.

Volgens een oude Boschnegerin is indertijd een man-Azema te Swampoe Kondre (aan de beneden-Marowijne) gevangen; voor zoover ik berekenen kan, moet het omstreeks 1840 zijn geweest. Het vonnis van levend verbranden werd over hem uitgesproken; dat behoort te worden uitgevoerd door de bloedverwanten van den veroordeelde en daar deze aan de Cottica woonde, werd hij daarheen opgezonden. De familie had er echter geen lust in en dus brachten zijn geleiders hem door de Wanekreek terug naar de Marowijne. Het bericht hiervan was echter vooruitgeloopen en den geleiders werd het bevel tegemoet gezonden om niet met den onverlaat terug te keeren. De lieden van de Cottica stuurden hem andermaal terug. Men meldde dat aan het Djoeka-bestuur aan de Tapanahoni, dat toen order gaf, dat de verbranding in de Wanekreek zou geschieden en dat de geleiders zich met dat werkje moesten belasten. Dat is geschied.

[Volgens Ho I 275, wordt het bovenzinnelijk vermogen asee genaamd en de bezitster daarvan aseeman en men onderstelt dat deze wezens, van wie een gloeiende straal uitstroomt, 's nachts rondvliegen om menschen, hiervan onbewust, het bloed uit te zuigen. 2 $\mathrm{Pa} 2$ De aséman geest draagt vuur in zijn handen].

SAR Azema is een bloedzuiger, is een wisiman. Schu 49 aseh hekserij, toovenarij, asehman heksenmeester, iemand die door tooverkunst menschen doodt.

STAD De Azema drinkt bloed. Als de Azema komt drinken, neemt

D1. 99. 
men abongra-zaden en strooit die buiten de deur uit; hij pikt ze alle op en als de dag hem overvalt, zie je hem; het blijkt een gewoon mensch te zijn, van wien men vroeger niet wist, dat hij een Azema was. Fo 6, Wu 249, 288 azé hekserij, toovenarij, azéman heks, vampier, die des nachts in lichtenden gloed rondwaart, om den menschen het bloed af te zuigen. Zie voorts $2 \mathrm{H} 43,2 \mathrm{~L} 22-25$, Bex III en $1 \mathrm{P}$ foto 4 „Hoe de negers zich een asema voorstellen. Deze blcedzuigende oude vrouw zou naar willekeur haar huid kunnen uiten aantrekken".

\section{$\S 48$. Wisi (booze toovenarij) en wisiman.}

Geen Djoeka en ook geen andere Boschneger, die niet in doodelijke angst leeft voor den wisiman. De wisiman toch, is instaat door toovermiddelen onheil en rampen over zijn medemenschen te brengen, hetzij lichamelijk, hetzij moreel of geestelijk, of op economisch gebied. Geen ongeluk en geen tegenspoed, of men stelt er een wisiman voor verantwoordelijk. Niemand sterft een natuurlijken dood en in negen van de tien gevallen is de oorzaak wisi.

Wisi kan bestaan in velerlei vorm, magisch of materieel, doch als regel is ze magisch en veroorzaakt een langdurig lijden, eindigende met den dood, of rampen, eindigende met maatschappelijken ondergang. De wisiman kan zijn kunst aan een ander leeren, doch kan ze ook op een ander overbrengen zonder dat die ander het beseft.

Hoe een wisiman werkt, weet niemand, doch er wordt wel verteld van de volgende methoden:

(1) een bakroe zenden; zeer kwaad zijn de lau-bakroe (lau=gek) die krankzinnigheid veroorzaakt, en de tamjakoe-bakroe (tamjakoe is het vischje Colomesus psittacus, dat zich op kan blazen, Enc 210) die zweribere, waterzucht, veroorzaakt;

(2) taai akra; men vermeestert de akra van het slachtoffer en spijkert die aan een Ceyba-boom of werpt haar in de rivier (zie nader $1 \mathrm{P} 160,2 \mathrm{H}$ 52, 103-104; ,binden van de ziel" noemt de Stadsneger ook, het offeren aan een onrustige akra en de magische handeling waardoor de eene echtgenoot maakt dat de andere niet ontrouw wordt);

(3) beri batra, flesch begraven; men doet de wisi in een flesch en begraaft die voor de deur van het slaclitoffer of op een plaats waar dit langs moet komen; zoodra hij loopt oyer die plek, dringt de wisi in zijn lichaam (ook 1P 164 en foto 3, Enc 751, Bex IX, MK); 
(4) seni ogri sani, een kwaad ding zenden, bijv. een tijger of een groote slang.

Bij een sterfgeval ondervraagt men het lijk (d.w.z. de jorka van den overledene) wat de oorzaak van het overlijden was. Blijkt het wisi te zijn en wijst het lijk iemand aan als schuldige, dan kan deze dadelijk gestraft worden. [2K vermeldt hoe het lijk van een vrouw, op de vraag of haar dood een bijzondere oorzaak had, bevestigend antwoordde. Plotseling renden nu de dragers met het lijk naar een hut en de bewoners van die hut werden eruit gehaald en zwaar afgeranseld; zie ook Ko 398-400. Nog ten tijde van Hostmann en Coster werd de als wisiman aangewezene levend verbrand].

Iemand van wien men vermoedt, dat hij een wisiman is, moet de kapitein van het dorp naar Drietabbetje sturen om er den eed aan Grantata $(\S 19)$ te vernieuwen. Indien hij inderdaad een wisiman is en den eed aflegt, zal hij weldra sterven [ C 18 vermeldt iets dergelijks]. Gebeurt er niets met hem en gaat het hem maatschappelijk goed, dan is het bewijs geleverd, dat hij geen wisiman is. Hij wordt dan op de meest eervolle wijze gerehabiliteerd en naar gelang hij in meerdere of mindere mate te lijden heeft gehad onder de verdenking, worden hem geschenken als zoenoffers aangeboden. In ernstige gevallen zullen zij aan de akra van den onrechtvaardig beschuldigde offeren.

Met zekerheid kan eerst na iemands dood worden vastgesteld of hij een wisiman is geweest, n.1. door zijn lijk te ondervragen ( $§ 82)$. Het lijk van een wisiman wordt weggeworpen, waardoor men voorkomt, dat hij, booze geest, vroeg of laat als ninseki van een kind op aarde terugkeert.

Het komt voor, dat later blijkt, dat de uitspraak van het lijk toch niet juist is geweest, doordien na het overlijden van personen die geacht werden het slachtoffer van den wisiman te zijn geweest, hun lijken verklaren, dat niet hij, doch een ander, de veroorzaker van den dood is geweest.

SAR De wisiman die iemand kwaad wil doen, werkt soms met vergif, doch zendt ook wel een geest.

STAD De wisiman die kwaad wil doen, zoekt je djodjo op en dan je akra. Hij moet naar de plaats van de djodjo gaan en waarschijnlijk licht zijn eigen booze geest hem in, waar die djodjo van den ander is. Zie voorts $2 \mathrm{H} 103-109$. 


\section{§ 49. Bakroe.}

De Bakroe is niet bekend bij de Djoeka's (zie echter bij Ampoekoe en wisiman $\S 24,48)$, wel bij de Paramakkaners.

STAD De Bakroe vertoont zich als een kleine jongen, ongeveer een meter hoog, die een groote mand op het hoofd draagt. Hij draagt braka maká, zwarte kleeren als een japon; de witte dragen een korte broek. De rechterzijde van den Bakroe is van hout. Hij slaat je. Als je hem kwaad doet, komt hij in je hoofd zitten.

[Uit de vele mededeelingen betreffende den bakroe, blijkt dat de oorsprong van het geloof dat men een bakroe kan tegenkomen, waarschijnlijk ligt in visioenen van houten poppetjes waarin een geest is, zooals obiaman's die kunnen maken en die men ook voor kwade doeleinden kan gebruiken. d. G.].

\section{$\S 50$. Poeroe wisi.}

Poeroe wisi is zich vrijpleiten van tooverkunst. De Boschneger heeft blijkbaar reeds in de oude tijden, in Afrika, geleefd in de gedachte, dat anderen zijn leven belagen. Hij heeft een ingeboren achterdocht, zelfs tegen zijn naaste omgeving. Daarmede hangt samen het begrip van wisi, vergiftigd worden, als regel met bovennatuurlijke middelen. De werking is lang niet altijd ziekte, gevolgd door spoedige dood, doch ook een aantasten der gezondheid, sleepende ziekte, melaatsheid, krankzinnigheid.

Om den gast, die een dorp bezoekt en daar spijs en drank krijgt, gerust te stellen, zal de gastheer of gastvrouw in tegenwoordigheid van den gast het eerst van de spijs of den drank nuttigen, daarmede uitdrukkend, dat de gast zich in het huis van vrienden bevindt en geen kwaad te duchten heeft. Men doet dit bij elk feestmaal en ook bij een gewoon bezoek. Zelfs wanneer de Boschneger bij een blanke komt en deze hem wat aanbiedt, zal hij den blanke vragen, of deze "no poeroe wisi" d.w.z. hem vragen, het eerst van spijs of drank te nuttigen. Hij die de spijs of drank aanvaardt, zal na het poer wisi zeggen , $m i$ (of $w e$ ) naki”, d.w.z. ik (wij) aanvaard(en) het, we twijfelen niet aan de eerlijke bedoeling [ook SAR, Schu 115].

Het poeroe wisi hebben de slaven uit Afrika meegebracht, doch zij vonden het hier terug bij de slavenhouders, die bang waren, dat ze inderdaad vergiftigd zouden worden door hun slaven en deze dus eerst lieten proeven. [2H 108 bezigt de uitdrukking poeroe wisi voor het uitdrijven van de wisi uit een zieke]. 


\section{§ 51. Ago.}

Men mag nooit achter iemand langs komen. Zit een gezelschap tegenover elkaar, dan zal iemand die naar de andere zijde wil, óf een langen omweg moeten maken, óf dwars door het gezelschap gaan. Is daarvoor geen ruimte, dan loopt hij wel achterom, doch roept hij tijdig ,ago”, d.w.z. „,ik heb geen andere weg”; het is een waarschuwing en tevens vergunning vragen. Hij wacht tot hij vergunning krijgt ,ga maar langs".

Spreek hierover met een Boschneger, en hij zal u uitleggen, dat dit hun van geslacht op geslacht is ingeprent en dat wie dat niet in eere houdt, zichzelf verlaagt en gelijk stelt aan den sluipmoordenaar.

Het ago heeft nog ruimer beteekenis. Zitten jongeren en ouderen samen en een jongere wil een oudere tegenspreken, dan zal hij ook eerst ,gi ago" (ago geven).

SAR Zie 1 H 134 en 1 H 326 agbo magische wachter (iets dergelijks 1P 173).

STAD Fo 2 ago uitroep der heidensche slaven om geesten te bezweren of kwaad af te weren; ook eenvoudig in de beteekenis van Let wel! geef acht!

\section{§ 52. Algemeene plechtigheden enz.}

De Djoeka's geloven, dat al de goden onderling voeling met elkaar houden omtrent het lot der menschen, en daarom worden om de zooveel jaren groote offerfeesten gehouden ten behoeve van alle goden tegelijk. Deze feesten duren soms maanden en worden altijd te Drietabbetje onder leiding van den Granman gehouden. Lang van tevoren wordt aan alle leden van den stam aangezegd, dat de Granman op zoo en zoo'n tijd „die go srika kondre" (voor het heil van het land gaat zorgen). Elkeen is dan verplicht de feesten, zij het slechts voor enkele dagen, desnoods slechts voor een uur, bij te wonen; zonder gegronde redenen mag niemand wegblijven.

[C 13 beschrijft een feest, dat in October of November, op den eersten Vrijdag van nieuwe maan begint en eindigt met de volgende nieuwe maan, ,dat een algemeen verzoeningsdoel heeft, om hen van hunne bedreven misdaden te zuiveren"].

Voorts is er het verjagen van Ampockoe (den opperste der booze geesten) uit het woongebied, dat op gezette tijden geschiedt, en in het bijzonder wanneer het geheele volk der Djoeka's door rampen en ziekten is geteisterd. 
Onder de obiaman's zijn er die bepaalde kruiden kennen en de handelingen kennen, noodig om Ampoekoe te verdrijven; deze menschen behooren tot de opo-negers en wonen op het dorp Akrekoena, even beneden Granbori. [Bij Wong 355 wordt melding gemaakt van den Krekoena Gado op het dorp Kisai]. Weken tevoren nemen zij kruidenbaden, houden gado-dansen enz. en dan wordt de dag bepaald. De Granman stuurt boodschappen aan alle dorpen, welke boodschappen door trommentaal worden herhaald. Iedereen moet weten, dat op den bepaalden dag na 6 uur 's avonds geen boot meer op de rivier mag zijn, wijl Ampoekoe de streek verlaat door de rivier, om, volgens hun voorstelling, door te gaan naar zee.

Op dien avond wordt op Akrekoena de gado-dans gehouden en den geheelen nacht door wordt de trom zeer intensief bespeeld. Als ze sterk in extase zijn, gebeurt het dat een der obiaman's roept ,daar gaat hij!" Ze volgen dan Ampoekoe naar de rivier en werpen hem kalebassen met kruidenmengsels achterna. Dit geschiedt omstreeks 3 uur 's nachts. Men zegt dat al de dorpen, van Godohoro aan de bovenrivier, tot Swampoe Kondre aan de beneden-Marowijne, her geraas hooren van Ampoekoe die voorbij komt; de toppen der boomen zwaaien en de aarde beeft.

\section{$\S 53$. Dansen.}

De dansen der Djoeka's hebben godsdienstig karakter. Het komt aan op de verschillende figuren en bewegingen die door de dansers en danseressen gemaakt worden; een kenner weet met den eersten oogopslag te zeggen, of men bijv. een Songee of een Awasa danst. Het is vrijwel verplichtend om te kunnen dansen.

De voornaamste dansen zijn de Toeka of doodendans ( $\$ 82)$, de Songee die bij groote feesten, zooals de Brokodéi (§ 84, foto's $2 \mathrm{~K}$ 213) gedanst wordt, en de Awasa. Voorts is er de Soesa, beschreven Enc 770-771 en Ve 324, 2H 579, $1 \mathrm{H} 98$.

Men danst ook gaarne bij de harmonica (foto Ve 324) en in latere tijden is een dans ontstaan, die het midden houdt tusschen Awasa en stepdans en Harmonica wordt genoemd; het rhytme wordt daarbij slechts zelden met de apienti-trom aangegeven, [bij de Bonni's was, in 1903 het gebruik van de trom bij dansen, tenzij wegens sterfgeval, verboden], meestal door slaan op leege kisten en blikken.

Dagboek d. G. 14 Aug. 1903 te Manlobbi aan de Tapanahoni. Bij de harmonica dansen eenige meisjes, daarbij in de handen klappend. 
op een flesch slaande en zacht meezingend, gebogen in een kring rond den muzikant kleine schuifelpasjes makend en de handen langs elkaar bewegend of klappend; ook wel tegenover elkaar. Idem 7 November 1903 op Enfants Perdus aan de Lawa (Bonni's). Eerst speelde alleen een man op de harmonica, en langzamerhand voegden zich daarbij bespelers van een leege flesch waartegen met een mes geslagen werd, en van een leeg blik en een leege kist die met de hand betrommeld werden. Het dansen bestaat uit bewegingen met de voeten in flauw gebogen houding, waarbij ze langzaam vooruit gaan. Onderwijl wordt dan met de handen gedraaid en dikwijls gezongen en in de handen geklapt, waarbij ze rinkelen met een band van pitten die boven den enkel om het been is gebonden. Zoo schuifelend komen de vrouwen dikwijls op een onzer af, en als ze dan vlak bij je is, is 't gewoonte een schijn-omhelzing te doen. - Later zweeg de harmonica en op de maat van snel blikgetrommel dansten ze ,baboen $j e ̂ ", ' n$ echte boschnegerdans waarbij een brulaap die zich den buik krabt wordt nagebootst (zie ook $1 \mathrm{~Pa}$ Am. Congr. XXIV 210).

De ,harmonica” heeft soms erotisch karakter. Bij de echte Djoekadansen mogen geen sexueele neigingen tot uiting komen, want dit zou de gado's of jorka's te wier eere de dans wordt gehouden, beleedigen.

Zie voorts Enc 260 vlg.

\section{Heilige voorwerpen enz.}

$\S 54$. Heilige bundels, beelden, kommen, godenhuisjes.

In een speciaal daarvoor ingericht huisje op Drietabbetje, wordt de heilige bundel of het paket bewaard, waardoor de godheid Gwangwella of Grantata zich bijzonder kenbaar kan maken. Het is een verzameling van reliquiën, zooals hoofdhaar, nagels, stukjes met bloed bevlekte kleeren van in den strijd gevallen helden, enz. Ook behoort ertoe zaad en wol van de eerste door hen geplante katoenstruik, uit welker product zij de eerste kleederen konden weven ,foe tapoe sjem", om de schaamte te bedekken. Deze voorwerpen zijn in een wit katoenen lap samengepakt en op een plank bevestigd. [Zie voor de geschiedenis van dezen bundel en zijn vermoedelijken oorsprong als oorlogs-obia, 2J, 3J 154, Wong 335, 337, 2K 209-210; omtrent de oorlogs-obia der Saramakkaners vermeldt $1 \mathrm{~J} 456$ „De Gran-obia moet de overwinning in den nog komenden strijd met de 
blanken brengen. Zij is de Ark des Verbonds der Saramakkaners". Sp 38 zegt, vermoedelijk van den bundel van een der Oppergoden: „Deze gadoe bestaat uit een groote klomp pimba-aarde ( $\$ 56)$, vastgemaakt op een smal stuk plank.... Deze gadoe wordt in een afgodshuisje zorgvuldig bewaard"].

Gedeelten van den bundel zijn aan Granbori (boven-Tapanahoni), Wanhatti (Cottica) en aan een dorp aan de Sara-kreek verstrekt, alwaar Gwanggwella-priesters aanwezig zijn (sedert Arabi overleden is, kan men echter te Granbori Grantata niet meer raadplegen). Het wordt geacht dat Grantata ook daarin aanwezig is. Om volmaakte hulp van Grantata te krijgen, moet men echter toch naar Drietabbetje gaan. $\mathrm{Er}$ is ook een bundel van Gedeosoe, welke te Tabbetje in een speciaal hutje wordt bewaard. Deze bundel is onverdeelbaar.

Elders heeft men een obia, een bundel van een lagere godheid, Afrakoe of Afrako geheeten. De bestanddeelen van zoo'n bundel zijn hoofdzakelijk van dierlijken aard, waar bij bloed en klieren van het hert een voorname plaats innemen, en verder plantaardige zaken. Op verschillende dorpen heeft Afrakoe ook een eigen naam. [Of Kangoe. 2F 17 en Asigoe 2K, zulke namen zijn, is niet zeker]. Een mensch kan door gebeden en daartoe strekkende ceremoniën leven aan het paket geven, wat bij Grantata niet mogelijk is; deze komt door eigen macht en wil in zijn bundel. [Vgl. voor zulk bezielen van een voorwerp, $\S 59$ en 1P 162; en zie over het verpakken van een bundel, en foto van het ronddragen te Granbori, 1G 53-54, 44].

Voorts zijn er huisjes, gado-hoso genaand [dikwijls beschermd door kifoenga, §61], die verblijfplaats zijn van de lagere goden; veelal is er een zeer ruw uit hout gesneden beeld van den god en verschillende andere heilige voorwerpen die bij den god behooren, alles rijkelijk met pimba besmeerd en potten met kruidenwater. [Bij de Saramakkaners zijn (zie 1H 239, 309, 2H 47, 3J 128, 159, 160) zwarte potten, gemaakt door oude vrouwen, een uitnemende verblijfplaats voor geesten; zulke boschnegerpotten zijn ook in de stad zeer gezocht, omdat hun kracht de kracht van daarin getrokken medicijn versterkt. Bij de Stadsnegers wordt ook de akra in een kommetje geroepen, zie $\S 5$. Stn III/1/184 vermeldt van de Saramakkaners ,zij hebben in hun huizen een paal waarop een klein, in de gestalte van een weefschietspoel gesneden stuk hout staat, waarin, naar zij gelooven, hun ziel woont"; daar offeren zij aan de ziel]. Foto's gadohoso 2K 211, 215, BONNI 1F 95, 96, Ve 328.

Dagboek d. G. 9 Aug. 1903 te Poeloegoedoe aan de Tapanahoni : 
Merkwaardig zijn de twee gesloten wintihoso's waarin men door een opening allerlei afgodstoestellen ziet; ook in ons huis was zoo'n klein soort altaartje. Id. 15 Aug. 1903 te Manlobbi aan de Tapanahoni: Vanochtend nam ik een kopie van eenig snijwerk, en bezag een der zinti-hoso's waarin een man bezig was boei's te maken, zijnde armen beenbanden die o.a. met wat mij toeleek een mengsel van schoensmeer en kruit te zijn, bestreken werden, en die den drager tegen schoten heeten te beveiligen. De verschillende afgodstoestellen daar zijn alle bestreken met witte aarde; ik zag er maar één die iets op een beeld geleek, daarentegen veel de z.g. kromtiki-gadoe, . krom gegroeide stokken, ook met pemba doti bestreken die somtijds worden rondgedragen met een miereneterstaart eraan vast.... Wat die gadoe's betreft, ze gelooven dat de geesten bij voorkeur in die toestellen gaan huizen, niet dat het zelf goden zijn. Idem 18 Aug. 1903 De boschnegers vinden onze rivierbakens (voor triangulatie) niet pluis, ze houden 't voor gadoe's. Een vrouw deed aan onze menschen 't verhaal: ,ik ging naar huis en zag plotseling dien gadoe en ik rilde".

- De zooeven genoemde kromtiki, kromme stok, door de Djoeka's ook kokoti geheeten, is een boompje, tak of liaan, die gegroeid is met een scherpen knik of een lus (foto $1 \mathrm{~F} 95$ en zie ook $2 \mathrm{~F} 180$ ). De kromtiki wordt wel door begeesterden als staf gedragen (zie $\S 37$ verhaal van Bajoeko). Bij de Saramakkaners heet zoo'n stok kongoeboesi (Schu 78 kokoti wandelstok; kongro list, streek; vgl. ook negerengelsch konkroe konkelen). 1H 97, 278-279 wie een liaan vindt, waaruit hij zoo'n stok kan maken, moet, voor hij haar afsnijdt, den god aanroepen, opdat deze hem niet naar zijn eigen vorm buige. $2 \mathrm{~Pa} 2$ vermeldt van Djoeka's kongo boesji, een god die de menschen pijn in de gewrichten geeft, als ze van de jacht in het bosch terugkeeren. Volgens Bex IV zijn de Boschnegers op hun hoede voor een krontiki in het bosch; er zijn mannelijke krontiki's waaraan de mannen, en vrouwelijke waaraan de vrouwen offeren. Schneider 22 vermeldt, dat men zoo'n stok bij een obiaman kan koopen en zich dan van den geest van dit voorwerp kan bedienen. De steel van een Paramakkaner-rammelaar was een met een knik gegroeid stokje.

- Volgens Melcherts, catechist-onderwijzer bij de Djoeka's, staat er bij den ingang van het dorp Tabbetje als wachter een beeld van Gedeosqe met drie oogen en twee horens. Volgens van Lier staat in Saramakkaner dorpen veelal bij den ingang een beeld met twee aangezichten, waarvan een naar de rivier en een naar het bosch 
kijkt; zie ook Martin 28 met plaat. Is dit een afrikaansch gebruik, Janus-hoofd ${ }^{1}$ ).

SAR Zie voor godenhuisjes 3J 158 vlg., $1 \mathrm{H} 273$ vlg; foto's $1 \mathrm{~K}$ 136, 140, 1H 158.

STAD 1P 171, Bex X, van Coll 565, Benoit 25 en fig. 36 vermelden hoe de loekoeman, wintiman of bonoeman een zvinti-hoso heeft, waarin kommetjes enz., die de winti's tot verblijfplaats dienen. Volgens MK X, XVIII had degene die bij een winti-dans door een winti bevangen werd, in het huisje van de bonoe een bord of kommetje tot verblijfplaats van die winti en als hij of zij wederom winti wilde dansen, moest hij aan de bonoe toegang tot het huisje vragen en dan de winti verzoeken op het feest te verschijnen.

\section{$\S 55$. Gebeds- en offerplaatsen. Fragatiki, Kréihoso, Kroetoehoso.}

De fragatiki (vlaggestok, hierop doelen $1 \mathrm{G} 36,43,53$ gadoe-paal en gadoe $)$ is een offerplaats. Een of ficieele fragatiki is er alleen op de dorpen die als bakermat gelden, niet op de vestigingen die als „buitenplaats” gelden.

De fragatiki bestaat uit een stijl met dwarshout waarvan over de volle breedte een lange witte lap, de fraga (vlag) afhangt, die symbool is van het hoogere. De fragatiki is omgeven door een vierkante bak, waarin een stuk platte rotssteen, waarop het offer geplengd wordt; er staan daar vele flesschen met water ten behoeve dergenen die er komen offeren.

De fragatiki is geplaatst vóór een open of half-open huis, de kréihoso (ween-huis), kroetochoso (vergaderinghuis) of granwanhoso (ouderen-huis, d.i. huis van de geesten der voorvaderen). Op Drietabbetje zijn er twee krćihoso's, een vlak bij den tempel van Grantata, dat dient voor den rouw van Granmans en andere hoogwaardigheidsbekleeders; het tweede kréihoso dient voor de andere bewoners van het dorp en daarin worden de kroetoe's, het dorp betreffende, gehouden. Foto's van het Grankroetochoso met Fragatik: te Drietabbetje 3L 117, Holdridge 217, kleinere fragatiki's $1 \mathrm{~F} 51$, 2K 213 .

Op vele dorpen zijn er nog andere fragatiki's, die gewijd zijn aan helden uit het voorgeslacht of anderen op het dorp geboren, die zich bijzonder verdienstelijk hebben gemaakt voor de $l o$. Zoo is er op

1) Waarover uitvoerig R. Karutz, Das Rätsel des Janus, Basel 1927. 
Poeketi de fragatiki voor Kentoe, die indertijd Bonni verslagen heeft.

Het planten van de vlag is niet ieders werk. Voorbeeld: Negers van het oude dorp Tabbetje hoog aan de Tapanahoni, hebben een dorpje, Akote gesticht aan de beneden- Tapanahoni, niet ver van Poeloegoedoe. De moeder-fragatiki blijft op Tabbetje, doch er is op Akote, waar kinderen geboren worden en zieken verpleegd worden, ook een fragatiki noodig. Deze wordt met de daarbij gebruikelijke ceremoniën door een priester geplant; kan men geen priester vinden, dan vraagt men er een aan Drietabbetje. - Toen ik eens op mijn standplaats den vlaggestok van mijn Nederlandsche vlag verplaatste, spraken Djoeka's mij aan, zeggende dat dit zoo maar niet gaat; en zij maakten er een ceremonie van, waarbij ze voor de Koningin baden enz.

Bij de fragatiki komen alle dooden samen en de levenden komen daar in contact met de dooden.

Stokjes met wimpels, de kleine fragatiki's, zijn de verblijfplaatsen der lagere goden. Vrome menschen hebben bij hun huis altijd een kleine offerplaats, waar vlaggetjes in den grond zijn gestoken. Maar ook bij mondingen van kreeken die men dikwijls binnenvaart, bij den ingang van een jachtpad of een pad naar een kostgrond, is er altijd een dergelijke begi presi (gebeds-plaats). Daar zijn stokjes met wimpels in den grond gestoken en veelal is er een soort stoel of tafeltje waarop de spijs- of drankoffers voor den gado en diens familie neergezet worden. De geofferde doeken worden aan lange in den grond gestoken stokken bevestigd.

Een man die een paar jaar thuis is geweest en nu met een nieuwe boot in de vrachtvaart gaat, zal, als hij voor vertrek gereed is, bij de fragatiki offereen aan de Granjorka's en bij de landing van zijs: dorp aan den gado van de rivieren. Wie voor een paar dagen het bosch in gaat, zal evenzoo offeren aan den geest die het bosch beheerscht, om voor zich en de zijnen bescherming te vragen.

Dagboek d. G. 25 Juli 1904 te Drietabbetje: Vele groote kankantri's (heilige boomen), meest met een offerplaats erbij; ook in sommige huizen kleine offerplekjes, waar dan doekjes hangen en leege flesschen staan. Bij ons huis staat een gadoe [fragatiki] van wel 5 meter hoog; gisterochtend waren de oudjes daar aan 't offeren: ze drinken wat dram en sprenkelen daarvan op den bodem; er wordt iets onverstaanbaars gezegd, en allen klappen van tijd tot tijd zachtjes in de handen. Bij 't woonhuis van den Granman staat een geweldige kankantri met offerplaats: een soort stoel en daarvóór stokken met 
witte en gekleurde lappen. Op den stoel en op den bodem staan tal van leege flesschen. Om den boom een liaan die 0.5 meter middellijn heeft. In het huis van den Granman hangen een paar prenten waarop Jezus is afgebeeld; hij kreeg die ten geschenke; erop wijzend, zegt hij : „massa gadoe!”

Idem 26 Juli 1904. Een paar jongetjes spelen voor ons huis met stokjes en lapjes: ,wat doe je?” - ,wij spelen gadoe; als ik volwassen ben wil ik een groot gadoe-maker worden"!

Idem 4 Augustus 1907. Een kankantri zal men nooit omhakken; wie dat doet, moet sterven. Dreigt zoo'n boom in een dorp, te vallen, dan verplaatst men de huizen. De palen met pandjes (kleedingdoeken), en korte palen zijn obia's voor ziekte. Zoo ook een mopé-boom, omringd door een vierkant van stokken waarvan palmbladfranje afhangt [zie $\S 61$ kifoenga], waaraan de Granman telkens nieuwe pandjes doet hangen.

Idem 1937. Voor een huisje op een eilandje in de vallen der Lawa staat een korte dikke houten paal, waarop een vlakke steen rust; naast den paal is een houwer in den grond gestoken. Hier bidt men tot den Kromanti-gadoe.

SAR De gádoe páoe (god hout) is hetzelfde als de fragatiki der Djoeka's. De kapitein en bastiaans vervaardigen de gadoe paoe. Foto's Eilerts de Haan 21, 1K 152. Men plengt water (toeé wátra) bij den gadoe paoe en bidt er de Granjorka, de geesten der gestorvenen, om hun voorspraak.

\section{§ 56. Pimba en grond.}

Het Opperwezen en de overige goden zijn wit; wat zwart is, is van den duivel. Nana heeft de menschen uit klei gemaakt. Daarom besmeert de Boschneger zich bij bijzondere gelegenheden met pimba of pemba (witte leem).

Men haalt de pimba uit den bodem, wascht ze uit en dan spreekt een priester er een gebed over uit; daarna eerst is ze werkzaam en wie er zich mee bestrijkt, heeft geneeskracht. Een pasgeboren kind wordt met pimba bestreken om te maken, dat het de goden en daarmee hun beschermende macht aantrekt. Men besmeert zich met pimba als men den gado (winti, § 36,37) over zich voelt komen (foto Vandercook 223). Enz. enz.; ook heilige voorwerpen worden met pimba besmeerd.

SAR Pimba dóti is het hoogste middel der Boschnegers; dat man- 
keert nooit. Men besmeert er zich mede om zijn Komanti $(\S \S 24,37)$ te versterken of om zich te beschermen tegen jorka. 3J 127 Boschnegers op weg naar het benedenland besmeeren zich dik met witte aarde om zich te beschermen tegen kwade invloeden.

Zie nog Enc. 562.

[Maar ook van den grond, of van aarde, gaat een krachtwerking uit; zie $\S \S 41,42$. En er bestaat een band tusschen den Neger en zijn geboortegrond, zie ook $3 \mathrm{~J} 128$ en $2 \mathrm{H} 49$. De Domini-negers, onderstam der Saramakkaners, halen de voor de vereering van hun godheid benoodigde roode aarde van de heuvels nabij Jodensavanne, waar hun voorouders slaaf zijn geweest (3J 161, 4J 334). In MK wordt verteld hoe de akra van een slavin in de stad, voortvluchtig is, en die akra houdt zich op op de plantage waar de slavin geboren was; om de akra terug te halen, heeft men wat aarde van die plaats noodig. Zie ook § 5 STAD verhuizen].

\section{$\S 57$. Kruidenbad.}

Den naam obia, waarmede de lagere goden of geesten bedoeld in $\S \S 12,23$ worden aangeduid, bezigt men ook om geneesmiddelen en voorbehoedmiddelen aan te duiden. Medicijn der Blanken noemt men bakra (Blanke)-obia, een europeeschen dokter noemt men bakraobiaman; want volgens hen houden ook de geneesmiddelen der blanken verband met het magische.

Onder de obia's nemen kruidenbaden een zeer voorname plaats in. Voor verschillende soorten van obia's zijn verschillende kruiden noodig. Door wassi obia, d.i. zich met een kruidenbad wasschen en daarna besmeren met een zalf of mengsel van kruiden en pimba, wordt de Djoeka immuun tegen alle kwaad dat een ander hem zou willen aandoen. Deze immuniteit moet op gezette tijden hernieuwd worden. De dag daarvoor is voor elken Boschnegerstam en zelfs voor elke $l o$ weer anders geregeld. Het geschiedt niet in de dorpen, doch op daarvoor uitgekozen plaatsen in het woud, omdat de vrouw er absoluut buiten moet blijven. Gedurende het obia-wasschen mag de Djoeka geen gemeenschap met een vrouw hebben en zelfs niet spreken met een vrouw of door een vrouw toegesproken worden. Vrouwen doen niet aan obia-wasschen op deze wijze; zij nemen kruidenbaden alleen bij ziekte of bij onvruchtbaarheid.

Volgens de overlevering was Bonni, hoofd der wegloopers wier nakomelingen thans de Bonni-Boschnegers zijn, immuun. Alleen op 
den dag vóór het obia-wasschen was hij kwetsbaar en ook door vijanden te naderen zonder dat zijn moejemboe (voorgevoel) hcm waarschuwde. Door hem een mooi meisje te zenden, kwamen de Djoeka's te weten welke dag dat was en toen hebben zij hem gedood, waartoe bovendien het geweer geladen moest worden met stukjes ijzer van een hamer dien men gloeiend maakte en toen in stukken kapte (4L, vlg. ook Wong 334-335).

Manningre-obia's zijn obia's, speciaal voor volwassen mannen bestemd. $\mathrm{Zij}$ worden benut om bedrevenheid in het gebruik van jachtgeweer en pijl en boog te verkrijgen en bekwaamheid in al wat met de jacht in verband staat, te bevorderen (alles wat met het geweer verband houdt, noemt de Djoeka manningre sani; Stedman I 88 mansani $=$ buskruit). Doch vooral dienen ze, om de geslachtsdrift aan te wakkeren en te verkrijgen dat de betrokkene, ook bij overmatig geslachtsverkeer niet impotent wordt.

De obia voor schietgeweer enz., bestaat uit plantaardige en dierlijke zaken. Hoofdbestanddeelen zijn hersenen van hert en konijn (agoeti); ook ingewanden van dieren die degene voor wien de obia bestemd is, gaarne schiet, worden bij het mengsel gevoegd. Dat alles, met speciaal voor die obia's bestemde kruiden, wordt in een groote tobbe, emmer of keulsche pot gedaan en aangevuld met veel water. Het vat met dit mengsel wordt dan enkele dagen aan kant gezet, om den inhoud te laten gisten. Is het mengsel rijp (,a lepi”), d.w.z. is het gistingsproces goed gevorderd, dan vangt het ,wasi obia" (het zich met de obia wasschen) aan. Een week lang baadt de betrokkene zich drie maal daags met dit vocht. De stank welke zoo'n man gedurende zijn badweek verspreidt, is niet te onderscheiden van de lucht van een rottend lijk, doch hij, noch zijn huis- of dorpsgenooten schijnen daar last van te hebben.

De bereiding en toepassing van erotische manningre-obia's geschiedt op nagenoeg dezelfde wijze, doch hierbij zijn de bestanddeelen hoofdzakelijk plantaardig, hoewel sommige recepten (er bestaan n.l. vele verschillende manningre-obia's) ook dierlijke bestanddeelen vorderen; een zeer voornaam bestanddeel is het schaamdeel van een volwassen landschildpad. Ook het roode haar van het achterste van een konijn, wordt als bestanddeel van een manningre-obia genoemd.

$\mathrm{Er}$ is ook een middel dat aangewend wordt als van een geweer de hagelbundel te veel uitspreidt; men doet dan een bepaald plantenpoeder in de patroon, en hierdoor zal het geweer weder gesloten bundels hagel schieten. 
Dagboek d. G. opreis Marowijne 1907. Onze vriend François besmeert zich elken dag schouders, ellebogen met modder, en gisteren en vandaag zat hij bovendien vol doode mieren, afgewasschen met een soort mierensoep; zeker is dat de een of andere obia-zaak. Idem 1937. Als mijn boot mij (in val Apoma) komt oppikken, wascht mijn stuurman zich met een kruidenbad, dat hij in een groote open kalebas achterin de boot medevoert. Hij spreekt daarbij ,obia” toe. Gevraagd, zegt hij dat dit hem kracht geeft; de kruiden had hij op het laatste dorp geplukt.

SAR De Boschnegers gebruiken niet als de Indianen tajers ${ }^{1}$ ) en drinken ook geen takini-sap of dgl. (waardoor een toestand van extase ontstaat), doch bedienen zich van boombasten en kruiden. Een plant heeft geen akra, maar heeft een kracht van zichzelf. Een blad kan alles doen; welke geest je aanroept, die komt in het blad en dan wordt het blad geneeskrachtig. De obiaman moet om zoo'n kruidenbad te bereiden, reeds bezeten zijn van Komanti (§ 24 (13)). De Christen-boschnegers gebruiken de geneeskrachtige kruiden ook, doch doen niet gelijk de heidenen, die er nog een geest bij aanroepen, die dan in het blad of op de bast treedt en de krachten versterkt.

$\mathrm{Er}$ is voor elk kruidenbad een tijdstip van den dag; soms moet het twee of drie maal per dag worden gebruikt. Op reis heeft men in de korjaal een aarden pot, agwang of poto geheeten, of een kalebas, met kruiden in water.

$\mathrm{Er}$ is ook een middel om een vrouw aan te trekken. Men neemt bepaalde kruiden en spreekt wizi' mi go pii vo mi koelá, Allessandrina a moesoe ke mi, blad ik ga je plukken tot mijn medicijn, A. ze moet liefhebben mij. Men neemt het blad mede, soms vele soorten, maakt een kruidenbad en wascht zich acht dagen lang daarmede en spreekt telkenmale den naam der vrouw uit; dan wordt die vrouw vanzelf verliefd op je. Dit middel heeft niet alleen uitwerking bij een geoorloofde, doch ook bij een ongeoorloofde liefdebegeerte ${ }^{2}$ ).

STAD In 1903 aan de Tapanahoni, had ik malariakoorts. Mijn kok, Stadsneger, wilde dat ik, precies op het middaguur, mij baadde met door hem in een blik gedaan water, waarin planten dreven. Zie voorts $2 \mathrm{H} 83$.

1) In Suriname bekend als tocralla (Kalienja-woord).

2) De Indianen hebben daarvoor een middel waarvan een bepaalde tajer-knol een bestanddeel is. 


\section{$\S 58$. Sangrafoe.}

Sangrafoe (Costus sp.) is een plant, waarvan het uit den stengel geperst sap een onmisbaar bestanddeel is van verschillende obia's en ook zelfstandig als medicijn gebruikt wordt tegen hoest.

Als iemand iets gegeten heeft, dat kina voor hem is en dat dadelijk daarop ontdekt, dan kan hij de kwade gevolgen opheffen, door sap van sangrafoe te drinken en het lichaam in te smeren met een mengsel van sangrafoesap en pimba. Op elk Boschnegerdorp is daarom sangrafoe aangeplant. Men drinkt het, sangrafoe-sap onder het prevelen van gebeden tot de gado's, in de eerste plaats den beleedigden gado, en vooral tot de Granjorka's, die altijd als pleitbezorgers worden aangeroepen. Heeft de betrokkene niet bij ongeluk, doch bijv. uit gulzigheid, van het verbodene gegeten, dan kan de sangrafoe hem niet helpen.

SAR 1H 18-19 vermeldt het gebruik van sangrafoe om den geest van een doode te scheiden van de levenden

STAD zie $2 \mathrm{H} 77$.

\section{$\S 59$. Amuletten en inentingen.}

De Boschneger is zeer gesteld op het dragen van amuletten, door de Djoeka's eveneens obia genoemd ${ }^{1}$ ), en gelooft heilig in de kracht daarvan.

Men kan ze indeelen in twee hoofdgroepen: de sabi, welke dient om iets te verkrijgen, en de tapoe, welke dient om iets af te weren. De Boschneger kan tegelijk sabi's en tapoe's dragen.

Bepaalde $o b i a$-soorten worden bereid door bepaalde specialisten. Zoo is de man die kassaba-obia bereidt, niet degene tot wien men bij voorkeur zal gaan om soema-moffo-obia te verkrijgen. De wetenschap om amuletten te maken, is het voorrecht van enkelen, die er zich goed voor laten betalen en hun recepten geheim houden. Die recepten gaan slechts over op nakomelingen of goede vrienden.

Degene die een amulet koopt, moet, om het werkzaam te laten zijn, het eerst nog laten wijden door den een of anderen priester. De

1) Het gaat hier en bij al wat men voor een fetisj zou kunnen aanzien, niet om vereering van het voorwerp als zoodanig, maar om den geest die van nature of door kunstmiddelen, in het voorwerp zijn zetel heeft. Vandaar dat de Djoeka en ook de Saramakkaner den naam obia bezigt zoowel voor den geest waardoor een mensch bezeten kan worden, als voor geneesmiddel, kruidenbad en amulet. Duidelijk uiteengezet $1 \mathrm{H} 320-321$. 
wijding bestaat daarin, dat de eigenaar het amulet op den grond legt; de priester plengt er water naast en vraagt daarbij aan de Granjorka's om hun hulp, opdat het amulet aan zijn doel beantwoorde. Dit geschiedt niet bij de fragatiki; in het algemeen komt men voor dergelijke kleine verrichtingen niet bij de fragatiki.

Er zijn talrijke soorten van amuletten. Ik zal er hier slechts enkele nader vermelden.

Door de kassaba-obia (kassavebrood-obia) neemt de drager de menschen voor zich in, verkrijgt hun gastvrijheid, en zijn verzoeken worden ingewilligd. Deze obia wordt als regel op de borst gedragen.

De manfeti-obia is een feti-obia (gevecht-obia) die overmacht bij een handgemeen geeft. Deze obia mag echter niet zoo bereid zijn, dat de ander er een ongeluk door oploopt, want dan zou het wisi zijn en in strijd met de leer van Grantata. Deze obia's zijn veelal ijzeren ringen (,boei"), die men om den bovenarm draagt. Als men een Boschneger ernaar vraagt, zal hij veelal zeggen, dat het maa: voor het mooi is; inderdaad is er echter niets, dat niet een bepaalde beteekenis of bedoeling heeft.

Soema-moffo-obia wendt het onheil van kwaadsprekerij door anderen, afgunst en laster af van den drager. Deze obia wordt als regel op de borst gedragen.

Takroe jorka-obia (booze jorka obia) beschermt tegen die geesten en wordt vlak onder de knie gedragen; bij de samenstelling zijn agoetiharen onmisbaar. Een belangrijke takroe-jorka-obia, doch dan niet voor het individu, maar voor een streek of dorp, is het kadaver van een stinkvogel (gier), opengespleten, de vleugels uitgespreid ei aan een stok vastgespijkerd, die nabij de landingsplaats van een dorp, op een rots nabij het dorp, maar ook wel eens midden in het dorp, in den grond staat.

Tijgertanden zijn een amulet van groote waarde voor het afweren van kwaad, vooral bij kinderen.

Papa-moni (kauri-schelpen) zijn een onderdeel van verscheidene amuletten.

Een lebitetéi (levens-touw) of gadotetéi is een talisman van groote waarde, die alleen door den Opperpriester gemaakt kan worden, die zich daarvoor royaal laat betalen; ze wordt om den hals gedragen en behoedt tegen ziekte en alle kwaad.

Een volwassen Boschneger heeft meestal bij zich zijn obia-kedere, zijnde een trommeltje of kistje, waarin hij verschillende amuletten heeft of ingrediënten om obia's te kunnen vervaardigen en ook pimba

D1. 99. 
(§ 56) en sneki-koti en sipari-koti, dat zijn inentingsmiddelen tegen slangebeet en roggesteek (zie hiervoor $\S 37 \mathrm{~d}$. G. dagboek 23 Nov. 1904, Enc. 643, Benjamins sneki-koti, Sta 212, Vandercook 211-213 en over nog andere koti's $\S 81$ en $2 \mathrm{H} 102$ ).

SAR Wat iemand aan het lijf droeg als obia tataai (obia touw), wordt bij zijn dood weggeworpen; niemand gebruikt het meer.

Een Boschneger zal u zijn obia tataai niet verkoopen, want het is van hemzelf, doch hij wil er wel een voor u maken, waartoe hij papa moni (kauri-schelp; verkrijgbaar bij Chineezen en Joden in de stad) koopt, enz. Hij spreekt er een paar woorden over uit, bijv. als het tegen wisi beschermen moet: obia mi ta méki joe fi ...fi...fi... hepi mi e wang sombe ta wisi a' moesoe kiri mi, obia ik mak je om mij te helpen en opdat, als een mensch toovenarij doet, het mij niet doodt.

Een lebi tataai (levens touw) maak je, als een jorka of dgl. je plaagt doch ik weet het niet precies.

Er zijn ook toovermiddelen voor de jacht, en vele andere.

Zie vooral $1 \mathrm{H}$ 320-321 enz.

STAD Wat de Djoeka's sabi en tapoe noemen, heet hier opo en tapoe. Zie voorts $2 \mathrm{H}$.

$\S 60$. Water plengen, spijs en drank offeren; tjindriengi.

$\mathrm{Er}$ is geen enkele godsdienstige handeling waarbij niet een offer wordt geplengd, en water komt daarbij altijd te pas (trozvéi wratra of poeroe watra).

Op mijn vraag aan een priester, waarom water zoo belangrijk wordt geacht, kreeg ik ten antwoord ,omdat de mensch, het dier en de plant, het zonder water niet kunnen stellen”. Toen ik opmerkte, dat de mensch het ook zonder vuur niet stellen kan, kreeg ik tot antwoord ,,ja, maar de mensch kan vuur maken, doch geen water, dat kan alleen het Opperwezen". Water wordt dan ook genoemd obia van Nana.

Wanneer bekend is, dat een vrouw zwanger is, dan komen aan de fragatiki de familieleden van de vrouw, ook die van den man en de goede vrienden. De oudste oom van moederszijde van de vrouw, plengt het offer van water.

Dat gaat zoo door. Bij de geboorte wordt water geplengd. Lijdt iemand aan hoofdpijn of kiespijn, dan gaat hij naar de oudsten in het dorp met verzoek voor hem water te plengen bij een fragatiki. 
Enz. Zelfs als een man op sterven ligt, gaan een paar van zijn vrienden nog vlug wat water plengen bij de fragatiki, of voor de deur van het huis, om het sterven te verlichten.

Men hoort ook sterke drank te plengen, doch de gado's en Granjorka's nemen er genoegen mee geen sterke drank te ontvangen, als degene die offert niet in staat is dit te geven.

De Djoeka heeft, nadat hij uit de slavernij in het bosch was gevlucht, voorloopig geen beschikking gehad over sterke drank en daarom keerde hij terug tot het uit Afrika medegenomen gebruik van zelf sterke drank te vervaardigen uit suikerriet, en dat geschiedt tegenwoordig nog voor bijzondere gelegenheden, vooral de offerfeesten aan de goden en de brokodéi's (§ 84) aan de Granjorka's. Het komt wel eens voor, dat men niet in staat is die geestrijke drank, tjindriengi genaamd, te bereiden; dan offert men extra veel met water en met rum van de kust, waarbij men de goden of Granjorka's smeekt, er genoegen mee te willen nemen, dat ze het voor dezen keer zonder tjindriengi moeten doen. Ik heb het eens medegemaakt, dat een oude Djoeka, wiens dochter een moeilijke bevalling had gehad, van de obiaman-priesters vernomen had, dat de Granjorka's wenschten dat hij bij de dankzegging zou offeren. Bij de plechtigheid wierp hij zich op de knieën in innig gebed, waarbij hij den grond kuste, en smeekte den Granjorka's hem te vergeven, dat hij niet instaat was hun tjindriengi aan te bieden.

Om de tjindriengi te bereiden, perst men het sap uit het suikerriet. Men kan dit doen met handpersjes, doch voor bepaalde gelegenheden is men verplicht de tjindriengi te bereiden op dezelfde wijze en met dezelfde werktuigen als in Afrika geschiedde. In een trog uit een harde houtsoort, bij voorkeur purperhart, doet men het in stukken gekapt suikerriet, in de lengte neergekegd. Over en weer staan de mannen met den stamper in de hand en pletten het riet. Het sap wordt in manari's (zeven; indiaansch woord) doorgezeefd en opgevangen in vaten. Men voegt een weinig water toe en laat het eenige dagen in de open lucht staan, waarbij het gaat gisten. De Bonni's stellen het vat niet in de open lucht, doch begraven het houten bootvormig vat of de pot waarin het sap, in den grond, gedekt met bananenbladeren.

Zie ook van Coll 543-544 en afbeelding van een suikerrietpers te Kaaimanston aan de Coppename, Bakhuis 40-41. Voorts dagboek d. G. 23 Nov. 1904 te Godohollo aan de Tapanahoni : Er is hier een soort kasjiri-korjaal (trog in den vorm van een boot, waarin de 
Indianen de gegiste drank, kasjiri, bereiden) vlak bij een suikerriettoestel; voor sommige feesten maken ze hierin een gegiste drank van het riet.

[Ook suikerwater is den goden welgevallig, § 23 offer bij Kassikassima en $3 \mathrm{~J}$ 86].

Het spijsoffer noemt men trowéi njejam (nederwerpen eten). Naar gelang het meer of minder welvarende menschen zijn, zal het spijsoffer in soort of hoeveelheid rijker zijn. Voor bepaalde feesten, meer speciaal rouwfeesten, mogen zekere spijzen niet ontbreken, bijv. schildpadvleesch [volgens C 18 een bijzondere lekkernij; 2K 214 vermeldt hoe men het bloed van kippen en schildpadden laat druipen op de voeten dergenen wier rouw eindigt], ook al ware de schildpad het totemdier van den afgestorvene.

Het spijsoffer vindt plaats bij alle belangrijke gelegenheden. De bedoeling is, dat de geesten van de afgestorvenen of ook wel de beschermgeesten van de menschen, gevoed worden. Zie voorts $\S \S 23,83$.

Aan de hoofdgoden wordt nooit spijs en drank geofferd; aan deze offert men alleen water.

Als men aan een der lagere goden offert, dan maakt men bij de stokjes met wimpel van dien god, de kleine fragatiki's, een barbakoto (rek) en legt daarop de spijs en drank, of bijv. een fleschje bier.

Als men een Djoeka vraagt, hoe hij komt aan deze ceremoniën en waarom hij ze verricht, dan is het antwoord: „Masra, datti na den weti di ben poti gi wi voe sensi granma teng", mijnheer, dat zijn de wetten die voor ons bestaan hebben sedert de tijden der voorouders (uit Afrika)"; sprekende van den tijd van hun wegloopen, zeggen ze lon lon teng.

\section{§ 61. Tjifoenga (Kifoenga).}

Het materieele van de tjifoenga is een horizontaal koord, bevestigd langs een stok of lat, die rust op twee krakken (mikken), geplaatst aan weerszijden van den toegangsweg tot een dorp of pleisterplaats, zoodat wie binnentreedt er onderdoor moet gaan. Alle toegangswegen worden van zoo'n tjifoenga voorzien. [foto $2 \mathrm{~K} 212$; ook gado-hoso's en offerplaatsen zijn wel door kifoenga's beschermd; foto Holdridge 216].

De werking van de tjifoenga's is, dat ze kwade geesten of booze machten beletten om het dorp binnen te komen en een mensch die 
met kwade bedoelingen komt, wordt machteloos zoodra hij onder de tjifoenga doorgaat, of erlangs gaat.

Bij plagen in het dorp, zooals kraboedago's die de kippen stelen, of een tijger die de honden weghaalt, en als er een groot feest zai gehouden worden, zuivert men het dorp van het kwaad en richt nieuwe tjifoenga's op om het buiten te houden. Die zuivering heet fom (slaan) tjifoenga. Het wordt hoofdzakelijk door de jeugd verricht en heeft het karakter van een vroolijk spel; het wordt in den ochtendstond verricht.

Op den daarvoor bepaalden dag is alles voor dag en dauw op de been. Er worden enkele geweerschoten gelost, om de booze geesten op te schrikken, en dan trekt de menigte erop los om onder helsch kabaal, op leege blikken en kisten slaande, het geheele dorp rond te gaan. De kinderen slaan tegen alle huizen, waarbij ze luid roepen ,eruit, eruit, niemand heeft jullie noodig, kwade geesten, wij willen in vrede in ons dorp leven; terug met jullie naar het ongeziene (,pe soema no de si oen")". Daarbij sprenkelt men met een uit rijsthalmen vervaardigden kwast het in kalebassen en houten nappen meegenomen zuiveringsvocht tegen het huis. Dat vocht is tevoren door een priester bereid uit water met kruiden en pimba en uitgedeeld aan de jongens die erom vroegen. De priester had aan de fragatiki het gebruikelijke offer gebracht en aan de Granjorka's den zegen over het werk ge. vraagd, waardoor het vocht gewijd was.

Op een gegeven oogenblik zijn allen samen gekomen op den hoofdweg naar de rivier; daar gaat een salvo geweervuur; een blij gejuich klinkt en men richt de nieuwe tjifoenga op. Ook voor de andere wegen en voor hutten waarin zich zieken of kraamvrouwen bevinden, worden kleine tjifoenga's geplaatst. De bewoonde huizen, vooral die van vooraanstaande menschen hebben een extra beurt gekregen en het is gebruikelijk dat het volkje dat zoo'n huis gezuiverd heeft, een belooning ontvangt.

SAR Een franje van maripa tongen (nog niet ontplooide bladeren van de maripa-palm) bij den ingang van het dorp heet Azáng en dient om kwaad tegen te houden. Foto's 4H 398, 1K 144, afb. Martin 28.

\section{$\S 62$. Bankje.}

Het in zijn waardigheid bevestigen van een Granman of kapitein. heet ,poti hem na bangi", hem op de bank zetten. Wordt er een belangrijke kroetoe (raadsvergadering) gehouden waaraan ook per- 
sonen van andere dorpen deelnemen, dan zal de kapitein als de vreemden aankomen, opstaan en aan den oudsten der gasten de bank waarop hij zat aanbieden. Deze wijst de eer beleefd af, verklarende dat de leiding der vergadering niet aan beter handen kan worden toevertrouwd dan die waarin ze zich thans bevindt.

SAR 1K 80, 1H 272, 325-326 (met foto's).

STAD Zie $1 \mathrm{P}$ foto 8 Bank van den obiaman waarop hij zit wanneer hij zijne begeesteringen oproept en $2 \mathrm{H} 47$ over de belangrijkheid van de bank.

$\S 63$. Trommen, rammelaar, hoorn of fluit, bel; tromen hoorntaal.

De trom is een heilig voorwerp bij alle Boschnegérs. Met groote devotie spreekt de Djoeka over zijn Koboewa-binsi-ankama, d.i. houtvel-bindtouw, de drie deelen waaruit de trom bestaat.

De Djoeka's gebruiken drie soorten trommen: de groote trom Apienti, de kleine trom Poedja en de groote trom Agida of Papadron (foto's $1 \mathrm{G} 70,2 \mathrm{~K} 212$ ). De trommen worden uitsluitend vervaardigd uit cederhout en vel van een hert (dia), luiaard (sro) of otter (njoen$d o e$ ) en als touw wordt uitsluitend zeilgras (siengrassi, Bromeliavezels) gebruikt.

De trom wordt gebruikt bij de gado-dansen, bij het oproepen van gado's enz. en voor het geven van signalen. De Apienti wordt het meest gebruikt, en wel bij verschillende dansen en voor het overseinen van berichten. De Poedja wordt hoofdzakelijk bij lijkdiensten gebruikt, bijv. bij het dansen van de Toeka (§ 53). De Papadron wordt in het bijzonder gebruikt bij offerfeesten gewijd aan de $P a p a$ gado en andere gado-dansen. Als de Granman op reis is, gaan er altijd eenige trommen mede; zie nader 3L I16.

Op de Marowijne brengt men van het eene naar het andere dorp berichten over naar Drietabbetje. De tromseinen zijn niet slechts bekendmakingen van algemeenen aard; men kan per trom ook bijzonderheden melden, gesprekken voeren en namen overseinen en de trommentaal der Djoeka's wordt ook door andere Boschnegerstammen verstaan. Kennis van de trommentaal is voor den Boschneger belangrijk; vroeger waarschuwde men door middel van de trom voor overval en thans nog zendt men bericht voor godsdienstige plechtigheden en men zendt geheele gebeden in trommetaal tot de goden.

Een bekwaam tromspeler staat in hoog aanzien. Op elk dorp zijn 
eenige bekwame tromslagers, wier taak het niet alleen is, bij voorkomende gelegenheid de trom te slaan (fon dron), maar ook om de jongeren het vak te leeren. Zie voorts 1L 86-90.

De Djoeka's hebben ook een blaasinstrument, de toetoe, die gebruikt wordt voor seinen van den eigen stam, of zelfs slechts van de eigen $l o$ (zie nader $1 \mathrm{~L} \mathrm{88);} \mathrm{bro} \mathrm{toetoe}=$ hoorn of fluit blazen. De toetoe is veelal van blik [vgl. het bij Benoit 62 en fig. 61 vermelde signaal-instrument; Lindblom 60 geeft een afbeelding van een houten toetoe].

De sakka-sakka, rammelaar, wordt gebezigd door den obiaman bij het oproepen van zijn gado, zie $\S 36$. Het is een uitgeholde kalebasvrucht, waarin zaden zijn gedaan en waardoor een stok is gestoken als handvat en veelal is de rammelaar rijkelijk met pimba besmeerd. Op de kalebas zijn figuren ingesneden, behoorende tot de attributen van den gado waarvoor de rammelaar is vervaardigd, hoewel hij ook gebruikt kan worden voor het oproepen van andere gado's.

Dagboek d. G. 26 Juni 1937 te Odoen aan de Lawa: In een huis is een man bezig een kalebas voor rammelaar te besnijden; er liggen er nog twee; er zitten maiskorrels in. Ik vraag aan den maker wat de ingesneden figuren beduiden: , ik heb ze gemaakt, maar weet niet wat ze beduiden".

Bel of tafelschel, zie $\S \S 20,37$ (26 Juni 1937), 1 G 64.

BONI Foto trom $1 \mathrm{~K} 58$ PARAMAKKA. Foto trommen $1 \mathrm{~K} 60$.

SAR Zie $1 \mathrm{H}$ index, en 331 ,The rattle is sacred to the Kromanti, and possession can be brought on by shaking it even when there are no drums"; 4H 399 foto trom en rammelaar.

STAD De loekoeman heeft een kleinen rammelaar. Zie voorts $1 \mathrm{P}$ 172 vlg. met foto's trommen, $1632 \mathrm{H} 87 \mathrm{vlg}$., $520 \mathrm{vlg}$. met foto's.

\section{Familie en recht.}

§ 64. Matriarchaat, polygamie, bloedschande, overspel.

De Djoeka's hebben een matriarchaat. Een familie staat onder het gezag van den oudsten oom van moederszijde.

Neven en nichten van moeders- en vaderszijde worden broers en zusters genoemd; die van moederszijde, vooral de kinderen van twee zusters, worden volkomen als broers en zusters beschouwd. Huwelijk of geslachtsgemeenschap is verboden tusschen ouders en kinderen 
of grootouders en kleinkinderen, tusschen kinderen van dezelfde ouders of van eenzelfde moeder of eenzelfden vader, tusschen oom en nicht, tante en neef en tusschen zusters- en broederskinderen. Nochtans komt bloedschande voor van een man met de dochter van zijn zuster, of van een vrouw met den zoon van haar zuster, of van een man met de vrouw van zijn moeder's broer of van een man met de vrouw van zijn zuster's zoon. Bloedschande tusschen ouders en kinderen of tusschen volle broers en zusters komt zelden of nooit voor.

Iedere man mag zooveel vrouwen nemen, als hij instaat is te onderhouden. Er zijn gevallen van vier tot vijf vrouwen die denzelfden man tot wettigen echtgenoot hebben. Granman Oséisi veroorloofde zich zelfs de weelde van zeven vrouwen. Dit is mogelijk, doordien er meer vrouwen dan mannen zijn en doordien vele mannen vrijgezel blijven. Er zijn echter ook gevallen, dat een man nooit meer dan een vrouw tot zich genomen heeft en de echtelieden tot den dood elkaar trouw zijn gebleven.

De polygamie is wettig en alle wettige vrouwen van een man zijn gelijkgerechtigd. Polyandrie bestaat niet.

Overspel is zeer gewoon. De man die betrapt wordt op overspel, wordt afgeranseld en mag zich niet verweren; de vrouw gaat vrij uit en in den regel zijn vrouwen er trotsch op, als vele mannen om hunnentwille zijn afgeranseld. Aan een verloofde of gehuwde vrouw het hof maken, geldt reeds als overspel. In vroeger tijden werd de, man die overspel pleegde met een vrouw van den Granman, ter dood gebracht.

Behalve bloedschande en overspel gelden ook tegennatuurlijke liefde en zelfbevlekking als ondeugden, doch deze komen zelden voor. Geslachtsverkeer tusschen nog onrijpe kinderen is niet zeldzaam. Prostitutie komt voor.

\section{$\S 65$. Gezin.}

Met de familie van vaderszijde bestaat er wel een band, doch niet zooals met de familie van moederszijde; zie voorts kina $\S 13$.

Vaders hebben zoo goed als niets te zeggen over hun kinderen, hoewel de vader wel den zoon onderwijst in wat deze noodig heeft. De Djoeka's leven in een los huwelijksverband; vaak gebeurt het, dat een vrouw uit meerdere opvolgende huwelijken kinderen heeft. Het kan gebeuren, dat de familie van een gescheiden man, of hijzelf, zeer gesteld is op een bepaald kind; dan kan het met vergunning 
van de ooms van moederszijde van het kind, aan de vaderlijke familie worden afgestaan om verder te worden opgevoed. Er zijn talrijke voorbeelden, dat zulke kinderen, volwassen geworden, geheel vervreemd zijn van de familie van moederszijde of zelfs van haar $l o$.

Een eerste huwelijk gaat gepaard met een groote plechtigheid; de volgende huwelijken zijn minder plechtig, doch worden toch met ceremoniën gesloten. Hoe oud de vrouw ook zij, behoeft men de toestemming van haar ooms en bij afwezigheid, van broers uit dezelfde moeder geboren. De voltrekking van het huwelijk geschiedt door het plengen van een offer door den oudsten oom of broer die aanwezig is, waarbij aan de Granjorka's de zegen over de verbintenis wordt afgesmeekt.

Bij de ontbinding van een huwelijk geeft de vrouw weer kennis aan haar ooms of broers, die ervoor zorgen moeten, zoo spoedig mogelijk daarvan kennis te geven aan de bloedverwanten van den man. Dit houdt verband met hun godsdienstige begrippen; immers, mocht een van beide partijen sterven, dan is het verplichte rouwdragen (tjari blakka) als vanzelf vervallen. Weet de familie het niet, dan zou een die den ander dupeeren wil, den eisch van in rouw gaan kunnen stellen, voorgevende niet te weten, dat de overledene voor zijn dood gescheiden was, en weigeren bij het offerbrengen aan den geest van den overledene, te memoreeren, dat hij de vrouw met rust moet laten, omdat die bij zijn dood niet meer zijn vrouw was. Evenzoo kan, als de vrouw gestorven was, haar familie den man dupeeren.

Als een van beide echtgenooten wil scheiden, dan zegt deze ,ik ga heen" en de ander zegt ,geef mij den tijd om het aan jouw familie te gaan zeggen". Vervolgens gaat men zonder meer uit elkaar. De scheiding gebeurt vaak met ruzie en men gaat boos van elkaar weg. Doch het komt meer voor, dat men zeer vriendschappelijk scheidt, waarbij de vrouw zelfs de bagage van den man naar de boot brengt, als hij de echtelijke woning en daarmee haar dorp zal verlaten en soms kookt ze nog zijn lievelingskost voor hem, voor de reis.

Bij scheiding mag in den regel elk kind voor zichzelf kiezen bij welke familie het wil blijven.

In vroeger tijden mocht de weduwe van een Granman niet hertrouwen, hoe jong zij ook ware. Van gescheiden vrouwen van een Granman is er voorheen nooit sprake geweest. Het kwam wel voor, dat de Granman een oudere vrouw niet meer bezocht, doch zij bleef niettemin met hem gehuwd. 
Een Granman kan uit dezelfde familie nooit meer dan één bruid bekomen en sterft de vrouw, dan kan hij niet een andere vrouw uit dezelfde familie huwen. Een orthodoxe familie zal ook bij gewone scheiding, niet door den dood, geen twee maal een jonge dochter uithuwen aan denzelfden man. Zelfs is het moeilijk uit dezelfde familie een vrouw te krijgen die gescheiden is.

\section{$\S 66$. Familie en $l o$.}

Groot is de saamhoorigheid bij den stam der Djoeka's in zijn geheel; in de $l o$ wordt die nog sterker en bij de familie nog weer sterker.

De gemeenschap is verantwoordelijk voor de daden van den enkeling, zooals de enkeling verantwoordelijk is voor de gemeenschap. Als bijv. een lid van de familie een schuld maakt en niet instaat is die te betalen, dan wordt de familie ervoor aangesproken.

Dit geldt echter niet alleen voor schulden. Als een jonge man een meisje verleid heeft en de familie van het meisje, die het recht heeft den man af te ranselen, hem niet kan vinden, bijv. doordien hij in de vrachtvaart is, dan wordt de straf toegepast op zijn broers of neven, zonder eenigen vorm van proces, en dit is een wettige daad. Zooals reeds gezegd, mag degene die gestraft wordt, zich niet verweren, wel wegloopen.

In zwaardere gevallen, bijv. als een verleid meisje gedurende de zwangerschap of in de kraam sterft, gaat de geheele familie van het meisje naar het dorp van den scht:ldige. De schuldige zelf is meestal reeds gewaarschuwd, bijv. door een hoornsein, en heeft zich uit de voeten gemaakt. Men haalt nu de daken van de hutten der familie, dringt naar binnen en vernielt het huisraad en in den regel vlucht de aangevallen familie. Vrienden van de aangevallenen zullen dan tusschenbeide komen en hun bemiddeling aanbieden om de zaak voor het gerecht te brengen, inplaats van dat de beleedigden hun wettig recht tot straffen zelve uitoefenen. [Zie ook Ko 397].

Het eenige wat verboden is, is het verwoesten van kostgronden (het te veld staand gewas) of beschadigen van booten. Ook mag een wreker nooit den ander in het bosch of op de rivier aanvallen, gelijk ook een man zijn vrouw nooit in het bosch of op de rivier mag afranselen. De gedachte die hierbij voorzit, is, dat een mensch niet weet hoe ver hij gaat; in het bosch of op de rivier zouden er geen anderen bij zijn, die een koel hoofd hebben gehouden en tusschenbeide kunnen komen, als het te erg wordt. 
Als een gehuwde man vertoeft op het dorp waar zijn vrouw woont, dan is hij verplicht dagelijks geslachtsgemeenschap uit te oefenen. Als hij op reis moet enz., vervalt die plicht. Doch indien hij te lang wegblijft, dan wordt hij naar huis ontboden en blijft hij weg, ondanks waarschuwingen en aanmanigen, dan gaat een deputatie van een of twee mannelijke familieleden van de vrouw naar hem toe, die hem voor de keus stellen, thuis te komen, of zijn kamisatrommel (trommel waarin een nieuwe lendendoek enz.) toegezonden te krijgen, ten teeken, dat de vrouw van hem scheidt.

Hoezeer men leeft onder den dwang der familie, moge blijken uit het volgende voorbeeld: Een man wil vracht gaan varen en deelt dit mede aan zijn moeder. De moeder zegt hem , ik denk niet, dat je oom er toestemming voor zal verleenen”. Op navraag bij zijn moeder, verneemt hij, dat die oom zijn diensten noodig zal hebben als voorman voor zijn eigen boot, of om een boot uit te hollen. Hij gaat naar den oom toe, die hem heel vriendelijk antwoordt, dat er niets geen bezwaar tegen is, dat hij vracht zal gaan varen, doch dat zeer waarschijnlijk tegen den tijd dat hij zal wegvaren, de oom er niet zal zijn om voor hem te offeren, zoodat de man dus intijds naar een ander zal moeten zoeken, die dat offer kan verrichten. In bedekte termen is daarmede uitgedrukt, dat de oom niet medewerkt. Want het water plengen is het werk van den oom; het kan wel door een ander gedaan worden, mits deze opdracht ontvangt van den oom. Zou er niet geofferd worden, dan heeft de man te duchten, dat zijn boot een ongeluk overkomt, doordien de Granjorka's niet gunstig gestemd zijn. Er zijn evenwel Djoeka's, die zich door zoo'n weigering van een oom niet laten weerhouden.

Gelijk reeds vermeld, is de familie verantwoordelijk voor de schulden van den enkeling en de schuld kan ten allen tijde opgevorderd worden.

De schuldenaar heeft daarvoor dwangmiddelen. Hij kan, na lang aanmanen, de familie dreigen, dat hij zich van kant zal maken, als de schuld niet onmiddellijk vereffend wordt. Bij de Djoeka's komt het voor, dat de bedreiging wordt uitgevoerd, en wel door vergif te drinken. Bij de Saramakkaners is het zelfs regel, doch deze schieten zichzelf voor het hoofd. Als gevolg hiervan, komt over de schuldenaren een koenoe $(\$ \S 14,88)$.

Bij de Djoeka's komt bovendien de leer van Grantata te pas. De schuldeischer kan de schuldenaren tot betaling dwingen, door een vervloeking over zichzelf of over zijn bloedverwanten uit te spreken, 
bijv. ,ik wensch, dat ik bij het weggaan van hier met mijn boot in de watervallen zink en verdrink". Of : ,ik heb geen geld om mijn kinderen te verzorgen; ik hoop, dat een slang een van mijn kinderen zal bijten". De doodzonde die met dit vervloeken wordt begaan, komt nu over het hoofd van de nalatige schuldenaren. Deze haasten zich dan, om voor de fatale termijn verstreken zal zijn, bij vrienden en geburen het geld te leenen, of een onderpand te vinden waarmede de schuldenaar tevreden zal zijn.

Gesteld, dat een man een ander beleedigd heeft, door diens vrouw tot ontrouw te verleiden, en dat de beleedigde noch dien man, noch een van zijn bloedverwanten kan vinden, om af te ranselen. Er kunnen jaren verloopen, maar de schuld verjaart niet. De vrees voor fiofio (\$15) noopt den beleeedigde iets te doen, om de zaak uit de wereld te helpen. Een der bloedverwanten of een goede vriend moet zich beschikbaar stellen om uitgescholden en gehoond te worden, hetzij door den beleedigde zelf of door een zijner bloedverwanten. [Over het uitvechten van een ruzie, merifeti geheeten, zie Ko 398].

\section{$\S 67$. Bezit der echtelieden, arbeidsdeeling.}

Echtelieden hebben elk hun eigen bezit, doch ze kunnen elkaar schenkingen doen. Gemeenschap van goederen bestaat niet. Man noch vrouw heeft tijdens afwezigheid van den ander het recht over iets van diens eigendom te beschikken.

Iedere man zal dadelijk bij het aangaan van een huwelijk voor zijn vrouw op haar dorp een huis bouwen. Wie sterk is en meer hulp heeft van bloedverwanten, bouwt bovendien op zijn eigen dorp een huis voor de vrouw. Bij scheiding behoudt de vrouw beide huizen. De man is verplicht voor zijn vrouw een kleine boot te maken, waarmede zij naar haar kostgrond gaat.

De man kapt een kostgrond voor de vrouw en de vrouw beplant dien. De man kan ook een kostgrond voor zichzelf kappen. Dien beplant hij dan zelf, geholpen misschien door zusters en nichten of zijn volwassen kinderen; de vrouw kan ook wel eens helpen.

De vrouw is verplicht den man eten te geven van de opbrengst van haar kostgrond; evenzoo is de man verplicht op jacht en ter vischvangst te gaan voor de vrouw. Het beheer van het eten berust echter geheel bij de vrouw.

De man koopt voor elk van hen beiden kleeren, hangmat en muskietenkleed en de vrouw onderhoudt ze voor beiden. Huisraad en 
eetgerei, ook dat wat de man voor het huishouden heeft gekocht of vervaardigd, blijft bij scheiding het eigendom van de vrouw. De man kan slechts zijn geweer, boog en pijlen, lijfskleeren en reservehangmat en zijn boot, medenemen.

\section{§ 68. Erfrecht.}

Ieder dorp is verdeeld in wijken. Elke wijk wordt bewoond door een bepaalde familie. De huizen staan dan oogenschijnlijk zonder systeem door elkaar gebouwd, doch de eigenaren weten precies te zeggen waarom elk huis zoo gebouwd is!

De Djoeka is zeer gesteld op vruchtboomen om en bij zijn woning. Het zijn hoofdzakelijk kokospalm, sinaasappel, manja, lemmetje, kasjoe, een bepaalde bakove-soort, door hen pangtakre genaamd. (De pangtakre wordt weinig gegeten, doch is onmisbaar, omdat bij de uitvaart van een doode naar de boot voor de begrafenis, de weg waarlangs het lijk zal komen, bestrooid wordt met trosjes pantakre, zoodat de jorka van den overledene overal voedsel vindt). De vruchtboomen blijven het eigendom van dengene die ze geplant heeft, hetzij de man of de vrouw.

Kinderen erven nooit van den vader [SAR idem, Sta 260, $1 \mathrm{H}$ 73], hoe welvarend die ook zij en hoezeer ook die kinderen de nagelaten eigendommen mede hebben helpen verdienen. Als een man sterft, dan wordt geërfd door alle zoons van al zijn zusters. Is een dier zoons dood, doch heeft hij mannelijke kinderen achtergelaten, dan zijn die erfgerechtigd. Als een vrouw sterft, dan wordt geërfd door hare dochters of, als ze geen dochters heeft, door de dochters van hare zusters. Zoons erven dus noch van hun vader, noch van hun moeder.

De bloedverwanten die met elkaar in vrede leven, zullen altijd bij een erfenis met elkaar raad houden, hoe de verdeeling moet geschieden; is de erfenis belangrijk, dan staan ze ook aan niet-rechthebbenden een deel af. Het gebeurt ook, dat neven die van hun oom erven, doch weinig of geen aanraking met hem hadden, terwijl de overledene meer door zijn eigen kinderen geholpen werd, afstand van hun erfdeel doen, ten bate van die kinderen. Om den overledene te eeren, zullen zij dan vragen, een voorwerp dat deze in dagelijksch gebruik had, te mogen hebben.

Ook de vruchtboomen behooren tot de nalatenschap. Zijn ze door den overledene geplant op een ander dorp dan het zijne, dan worden 
ze in den regel ten geschenke aangeboden aan den een of anderen bewoner van het dorp waar ze staan, meestal aan het dorpshoofd. De andere eigendommen worden door de nieuwe eigenaars weggehaald; een huis kan de erfgenaam afbreken en naar het dorp waar hij woont, vervoeren.

Behoudens het vorenstaande, maakt iedereen vóór zijn dood zijn uiterste wil en verdeelt zijn aardsche goederen, zooals het hem belieft. Het gebeurt wel eens, dat na den dood van iemand, die veel heeft nagelaten, de erfgenamen elkaar het een of ander betwisten, of de een zich benadeeld acht ten bate van de anderen, enz. Is het lijk nog niet begraven, dan laat men den geest van den overledene uitspraak doen (zie § 82); aan die uitspraak houdt men zich dan stiptelijk.

\section{$\S 69$. Rechtspraak.}

Wie op domeingrond $(\S 1)$ bouwmateriaal wil halen, of een boom kappen, of er wil jagen, heeft vergunning van den Granman noodig. Overtreding wordt onverbiddelijk gestraft met afnemen van het weggehaalde en de delinquent mag blij zijn, als er niet een zware boete bij komt. Recidivisten worden voor het gerecht gehaald en zelfs met dwangarbeid gestraft.

Op het terrein toebehoorende aan een familie, mag elk lid dier familie, zonder aan iemand vergunning te vragen een boom vellen om er een boot van te maken, bouwmateriaal verzamelen, tas-bladeren (voor dakbedekking of als bootsdekking) halen, nekoe kappen ( $\$ 80$ ) of een kostgrond aanleggen. Mits echter niet een ander er reeds beslag op had gelegd en dat door een duidelijk merkteeken had aangegeven. In zoo'n geval moet het onrechtmatig genomene worden teruggegeven, een gevelde boom zelfs, ook al is er reeds een boot van gemaakt. In den regel wordt het door ouderen in der minne geschikt. Moeilijker is het echter, als het is geschied op terrein van een andere familie of een andere $l o$, in het bijzonder als het een $l o$ is waarmede men niet op goeden voet staat. Het komt voor, dat de overtreder zich verzet tegen de beslagneming en de andere partij de zaak voor de rechtbank brengt. Is hij veroordeeld en verzet hij zich door den aanplant te vernielen of de boot onbruikbaar te maken, dan maakt hij zich daarmede schuldig aan een feit waarop een zware straf staat.

De man die met een andermans vrouw overspel heeft gepleegd, wordt door den beleedigde gekastijd, gelijk reeds beschreven ( $\$ 64)$, 
doch daarna komt de zaak nog voor een rechtbank, bestaande uit oudere familieleden van beide partijen. In den regel wordt de beleediger dan veroordeeld tot excuses aanbieden en daarop drinkt men de zaak af. Doch als de beleedigde die komt straffen, zelf zou worden afgeranseld door familie of vrienden van den ander, dan is het een ernstig geval, dat slechts door het hoogste gerecht, te Drietabbetje, kan worden berecht.

Men neemt ook in aanmerking wat de gevolgen zijn geweest. Zoo bij het verleiden van een meisje ( $(64)$ en bij vervloeking ( $(41)$, als iemand sterft en het lijk, ondervraagd, te kennen geeft, dat de vervloeking de oorzaak is geweest. Maar ook verzachtende omstandigheden laat men gelden.

Elke zaak, onverschillig waarover het gaat, wordt in eerste instantie door den familieraad, bestaande uit de oudste mannelijke leden der familie, behandeld. Gaat het over een geschil tusschen twee of meer menschen, dan nemen de ouderen van alle daarin betrokkenen, zitting in dien raad (kroetoe). Kan men niet tot een vergelijk komen, dan wordt de zaak gebracht voor Pranasi, hetgeen in dit geval beteekent de dorpsrechtbank, waarvan de leden zijn afgevaardigd door de dorpen van hen om wie het gaat.

Een volgende instantie is de raad uit de $l o$, of zoo noodig $l o$ 's.

Ook hiervan kunnen de rechtzoekende of diens bloedverwanten in hooger beroep gaan. Maar nu wordt de Granman erin betrokken. Deze roept den raad der opo- of der bilo-kapiteins te Drietabbetje bij elkaar, al naar gelang het een zaak van opo- of van bilo-Negers is. $\mathrm{Na}$ zeer ampele en vooral langdurige beraadslagingen doet deze raad uitspraak.

En zelfs hiervan kan men in beroep komen, bij den raad van de opo- en de bilo-kapiteins bij elkaar, de Grankroetoe. Deze beslist nu in hoogste ressort, waarbij echter de Granman het recht van veto heeft.

Nog moet ik vermelden, dat onder de Boschnegers er een soort jury-rechtspraak is; elke volwassen man van den stam is vanzelfsprekend jury-lid, onverschillig op welk dorp of onder welke $l o$ de zaak behandeld wordt. In de vele pauzen gedurende de zitting, hebben de jury-leden, het volk of ,lanti", zooals men ze noemt, gelegenheid hun meening aan de rechtsprekenden kenbaar te maken, die ter dege rekening houden met de zienswijze van de meerderheid.

Vrouwen worden nooit, tenzij als toehoorsters, op een kroetoe toegelaten; stem in het kapittel hebben zij nooit, uitgezonderd wan- 
neer het huwelijks-, scheidings- of verzoeningsaangelegenheden betreft. Dan nemen zij niet alleen deel aan de kroetoe, doch hebben het hoogste woord en de beslissing hangt in den regel af van de meerderheid der vrouwen die aan de kroetoe deelnemen. Het gebeurt vaak. dat als de beslissing tegen den zin der vrouwen uitvalt, zij revisie vragen. Alsdan houdt een verdubbeld aantal familieleden en onpartijdige buitenstaanders een nieuwe kroctoe. Daarna kan de zaak nog in hoogste ressort voor den Granman gebracht worden.

\section{$\S 70$. Straffen.}

De Djoeka huldigt het begrip, dat het kwaad gestraft móet worden, en dat geldt vooral voor zonde tegen de een of andere godheid, vooral Grantata. De straf is in het belang van den overtreder zelf, want wordt deze niet door de aardsche rechters gestraft, dan is hetgeen hem wacht van de onzichtbare rechters veel erger. Doodzonden, vooral in verband met de leer van Grantata, kunnen alleen met lijfstraf vergolden worden. Zelfs de Granman, hoewel volgens de Boschnegers drager van een gado, ontkomt daar niet aan.

Het volgende is uitgelekt, hoewel het streng geheim werd gehouden. Granman Oséisi had pikado (bloedschande) gepleegd, wat een ernstig vergrijp tegen Grantata is. Zijn zaak werd behandeld door een kroetoe (vergadering) van enkele zeer hooggeplaatsten, onder leiding van zijn neef en tegenstander Arabi (foto $2 \mathrm{~F}$ 81), en aan Oséisi werd een lijfstraf opgelegd. Wegens de hooge positie van Oséisi kon de straf slechts door Arabi worden ten uitvoer gelegd. Arabi had dat symbolisch kunnen doen met een lichten tik, doch hij heeft Oséisi zich in een afgezonderde hüt naakt laten ontkleeden en hem drie harde zweepslagen toegediend. Hierbij waren aanwezig kapitein Tjori (genoemd 1G 33; bij zijn dood bleek, dat hij een wisiman was, maar Granman Amakti heeft hem toch laten begraven) en een ander.

Op zware misdrijven, zooals wisi of moord of de vrouw van den Granman, of van een anderen man van hoogen stand verleiden, stond vroeger de doodstraf. De raad van kapiteins, opo en bilo samen, was bevoegd de doodstraf uit te spreken; de Granman had het recht van veto. De Granman was echter eveneens bevoegd een doodvonnis uit te spreken.

De zwaarste straf was levend verbranden [met marteling volgens Stn II/2/51, 268-272 (Saramakkaners), Ho I 37-40, 273, C 18-19; 
de schuldige werd daartoe aan de familie van zijn slachtoffer uitgeleverd]. Voorts was er de straf van ophangen aan den nek en die van onthoofden met een houwer [het opperhoofd Bonni verrichtte, Volgens Coudreau 24, dat persoonlijk]. De executie geschiedde in den regel op het dorp waar de schuldige thuisbehoorde, en zulks met het oog op de koenoe ( $\$ 14)$ geschapen door het doodvonnis. Ook wel werd het vonnis uitgevoerd op een der bepaald daarvoor aangewezen plaatsen, zooals Sangamasoesa. Het lijk werd (evenals geschiedde met het lijk van een na zijn dood als wisiman herkende), weggeworpen op een bepaalde plaats in het bosch, ver van het dorp.

Granman Abraham Blijmoffo heeft, toen hij an het bewind kwam $( \pm 1866)$ de doodstraf afgeschaft. Arabi betreurde dit altijd; hij was van meening, dat de Djoeka's niet zonder den strop te regeeren zijn.

Vermogensstraffen worden vaak toegepast. Boeten in den vorm van een of meer damejeannes rum, of een boot, enz., zijn aan de orde van den dag. Deze boeten komen alle aan den Granman persoonlijk.

Ook bestaat er de vrijheidsstraf, met of zonder dwangarbeid, als het openvellen van een kostgrond of uithollen van een boot voor den Granman.

Men kan voorts tot werkeloosheid veroordeeld worden, moet dan den tijd in nietsdoen doorbrengen en leeft van de familie of van hetgeen anderen uit liefdadigheid geven.

Een zwaarder straf is het den ganschen dag op een plaats in de zon moeten zitten, den eenen dag met het gezicht, den anderen dag met den rug naar de zon gekeerd. Ook bestaan er onteerende straffen, zooals het onderhouden van den reinigingsdienst voor de honden, in een dorp waar vele honden voorkomen. Dat men daarbij geraffineerd te werk kan gaan, getuige een staaltje, mij bekend uit den tijd van Granman Amakti's voorganger, waarbij een jongeman, die als een echte Don Juan bekend stond en reeds vele keeren gestraft was, wegens het tot ontrouw verleiden van anderman's vrouwen voor het ondergaan van l.g. straf werd gedetacheerd in een dorp waar vele jonge maagden aanwezig waren!

Zie nog voorbeelden van strafzaken 3 LI 3-5.

D1. 99. 
VII. Het leven.

$\S 71$. Vóór de geboorte.

Als de vrouw zwanger is, mag de man haar niet verlaten, vooral niet als het nog een jonge vrouw is, en bij een eerste zwangerschap is het volstrekt uitgesloten, dat hij weggaat. De familie van de vrouw waakt daar streng voor.

Iedere man heeft op zijn dorp zijn eigen huis, doch is bovendien verplicht voor elke van zijn vrouwen op haar dorp een huis te bouwen. Elke vrouw kan echter in het huis van haar man een tijd vertoeven, gelijk ook de man in het huis van een zijner vrouwen kan slapen. Het komt voor, als een man ziek is, dat er twee vrouwen in zijn huis zijn, die het goed met elkaar kunnen vinden. Een welvarend man, die een vrouw op een ander dorp heeft, heeft voor die vrouw niet alleen op haar dorp, doch ook op zijn eigen dorp, een huisje gebouwd.

Gedurende de zwangerschap is de man verplicht elken nacht bij de vrouw te slapen. Het is voorgekomen, dat op hetzelfde dorp twee vrouwen van een man zwanger waren en hij verplicht was de halve nacht bij de eene en de andere helft bij de andere te slapen. Men meent, dat dit de bevalling zal vergemakkelijken. Het is vaak voorgekomen, dat als een vrouw in de kraam stierf en bleek, dat de man gedurende lange tusschenpoozen niet bij haar was geweest, de man door de familie der vrouw verschrikkelijk werd mishandeld en gehoond en die familie weigerde hem in rouw te zetten ( $\$ 83)$. Een jonge man, die in de vrachtvaart ging en zijn vrouw zwanger achterliet, werd met de sterke hand teruggehaald. - Men meent ook, dat het kind steviger zal zijn, naar gelang gedurende de zwangerschap de vader meer gemeenschap heeft met de vrouw. [idem SAR 2H 54].

Wanneer bekend is, dat een vrouw zwanger is, dan komen aan de fragatiki de familieleden van de vrouw, ook die van den man, en de goede vrienden samen, en de oudste oom van moederszijde van de vrouw plengt het offer van water. Men plengt ook sterke drank, doch dit is niet onmisbaar.

De man mag gedurende de zwangerschap van zijn vrouw geen schop hanteeren en is hij daartoe om de een of andere reden genoodzaakt, dan kan hij het kwaad ongedaan maken, door de schop ondersteboven in den grond te steken en gedurende een etmaal zoo te laten. Als de man tijdens de zwangerschap met de schop zou blijven 
werken, dan zal de vrouw in de kraam sterven. Zie voorts bij nekoe $\S 80$.

Men raadpleegt den heiligen bundel die op het dorp is, over de vraag, van waar het kind ,gekomen is”, d.w.z. door welken gado (§ 10) het ,gezonden is”. Zoodra men weet, waar de betreffende gado zich ophoudt, begeeft men zich naar diens woonplaats, ook al zou die dagen ver weg liggen en begint daar met de gebeden voor een spoedige bevalling, gezond opgroeien van het kind, enz.

\section{$\S 72$. Geboorte.}

Bij de geboorte mag elk vrouwelijk kind, hoe jong ook, aanwezig zijn. Wijst men hen erop, dat dit niet geschikt is, dan is het antwoord: ,zij zijn vrouwen, bestemd om eens te baren en kunnen het niet vroeg genoeg zien".

Op elk groot dorp is er een vroedvrouw, die den naam van mekiman draagt. Gaat alles goed, dan wordt de zaak aan haar overgelaten. Komen er stoornissen, dan raadpleegt men de gado's (winti's) en blijft het geval moeilijk, dan roept men den Dinga-gado, die meer dan de andere gado's zich bezig houdt met verloskunde, te hulp. Door de kruiden die dan door den obiaman uit het bosch gehaald worden (hij gaat soms in het donker in het bosch en komt terug met de bladeren!), wordt de bevalling geholpen. Men stampt die kruiden en wrijft er de vrouw mede in of laat ze haar innemen, of druppelt het kruidenwater in oogen, mond en neus. Dikwijls komt het dan terecht, doch niet zelden sterft de vrouw in de kraam. Is de vrouw vóór den partus in de kraam gestorven, dan moet daarna de partus volbracht worden.

Men neemt de grootste voorzorgen tegen kouvatten der kraamvrouw. De hut waarin zij bevallen is, blijft gesloten en er brandt voortdurend een houtvuur in. Elken avond, gedurende tenminste een maand, moet de vrouw naakt op een plank boven een bekken met kokend water zitten, waarbij ze overdekt is, zoodat de stoom haar omspoelt. Ook bij Stadsnegers en creolen bestaat dit gebruik, hoewel tegenwoordig minder dan voorheen.

Is het kind een meisje, dan blijven moeder en kind 7 , is het een jongen, dan blijven ze 9 dagen in de gesloten hut ${ }^{1}$ ). De reden daarvan is, dat een vrouw 7 ribben heeft, en een man 9 , volgens de

1) Härtter, Angloer (Afrika) dochter 36, zoon 12 dagen. En vgl. Leviticus 12. 
Djoeka's. Of men dit al tegenspreekt, helpt niet, want „,de ouderen hebben het gezegd" ${ }^{2}$ ).

\section{$\S 73$. Naam.}

De weeknaam, de naam van de akra van een mensch, is vanzelf gegeven door den dag der week waarop hij of zij geboren is. De weeknaam wordt niet geheim gehouden.

Bovendien kan een Djoeka nog een anderen naam hebben. Deze naam kan reeds vóór de geboorte door de ouders bepaald zijn, voor het geval het een jongen zal zijn en voor het geval het een meisje zal zijn.

Het duurt soms dagen, ook wel weken en langer, voor er een beslissing genomen is, hoe een kind zal heeten. Men gelooft, dat als men aan het kind den naam van een ander geeft, diens goede eigenschappen op het kind zullen overgaan. Als bijv. op een dorp een vrouw woont, die sterk en flink is en geacht door de dorpsgenooten, dan gebeurt het, dat de jonge moeder haar pasgeboren dochtertje gaarne naar die vrouw wil noemen. Men vraagt die vrouw, met de noodige plichtplegingen, of zij haar naam aan het kind kan verkoopen. Bescheiden antwoordt de vrouw „och, wat heeft het kind aan een wisizvasi (onbeduidende) naam als de mijne. Mijn naamgenoten zijn geen gelukkige menschen; zou het niet beter zijn een anderen naam voor het kind te kiezen? De familie blijft aandringen, erop wijzend, dat haar bescheidenheid en eenvoud juist groote eigenschappen zijn, die men gaarne in het kind wil zien. Dan geeft ze toe. De prijs ervoor wordt bepaald door de familie van het kind en bestaat uit een of ander gebruiksvoorwerp of kleedingstuk, een enkel maal uit geld. Die het aanbiedt zegt ,hier is de betaling voor den naam”. De ander antwoordt „De naam wordt met heel mijn hart gegeven (nanga brofoe hatti, met hartslag), wij zijn geen gelukkige menschen, maar leven onder Gods genade". De vrouw brengt dan, zoo gauw het kan, een geschenk aan het naar haar genoemde kind. Hoewel zij haar naam verkocht heeft, blijft ze zelf toch ook dien naam voeren.

Het kind is nu de ninseki van die vrouw geworden, doch dit is niet de reinkarneerende geest, besproken in $\S 9$.

Ook van Europeanen die hun achting genieten, geven ze gaarne

1) Vgl. nog Herskovits, Dahomey, II 234: de Dahomeyanen gelooven, dat mannen 4 , vrouwen en kinderen 3 zielen hebben. 
den naam aan hun kind; zoo zijn er aan de Tapanahoni een De Goeje, twee Dr. Bonne's en meerdere van Lier's (voor welke namen niet betaald is!).

Ander voorbeeld: een jonge man heette Atrongoutoe (hij is goud geworden). Hij was het kind van een ongehuwde moeder, die toen zij zwanger bleek te zijn, verschrikkelijk door de familie gehoond was. Doch toen het kind geboren was, werd het aller lieveling en de moeder die zelf een naam moest geven, koos dezen naam als een soort represaille.

De Bonni-negers geven vaak dierennamen aan hun kinderen, bijv. Kwatta, Mekoe, Dia.

- Voorts moet, als het kind eenmaal ter wereld is, onderzocht worden wie zijn ninseki ( $(9)$ is; men raadpleegt daartoe den heiligen bundel. Zoodra men weet, wie de ninseki is, offert men aan diens geest en roept zijn bijstand in voor bescherming van het kindje. Dit is een plicht die niet verzuimd mag worden, immers zou dan de gezondheid, zelfs het leven van het kind in gevaar verkeeren. Ik heb het bijgewoond dat op een dorp vele zuigelingen ziek werden. Men raadpleegde Afrako (dat is de naam van den in den heiligen bundel aanwezigen geest) en vernam, dat de kindertjes ziek werden omdat hun ninseki's nog niet bekend waren. Langer dan een week was toen het geheele dorp bezig om met behulp van Afrako te zoeken naar de ninseki's.

De heilige bundel, op een lat bevestigd, wordt door twee mannen op het hoofd gedragen. Een der ouderen van het dorp komt staan voor den voorsten drager en begint met de vraag ,obia, zult ge ons naar waarheid, zonder den spot met ons te drijven, eerlijk antwoorden op hetgeen wij u vragen zullen? gij ziet in de duisternis voor ons; het vermogen hebt gij, zoowel naar voren als van achteren (in de toekomst en in het verleden) te zien".

En verder nog een heele toespraak. Vervolgens zegt hij: „op ons dorp zijn vele kinderen die ziek worden en velen zijn zelfs gestorven (dit zegt men zelfs als er nog geen een gestorven is; het is niet bedoeld als leugen, doch een soort hoffelijkheid) en nu moet gij ons helpen; zeg ons wat de oorzaak is; wij veronderstellen dat het is, omdat ze hun ninseki niet kennen. Is de ninseki reeds lang dood? geef daarop antwoord"!

Dan gebeurt het, dat de voorste drager het hoofd rechts en links beweegt als ontkennend antwoord; worden daarentegen beide dragers onrustig en maken ze aanstalten om van de plaats te gaan, dan is 
de vraag bevestigend beantwoord. Nu volgt een tweede vraag: „Heeft hij hier op het dorp gewoond?" Indien dit bevestigend beantwoord wordt, vraagt men verder en noemt achtereenvolgens verschillende namen en zoo vindt men den naam uit en als dat gelukt is, dan gaat een groot gejuich op.

Het kan ook moeilijk zijn, soms dagen of weken duren, telkens een paar uur per dag. De vrager zoowel als de dragers, moeten door de familie beloond worden, vooral de ouderen; de dragers zijn als regel jongere mannen van het dorp. Men betaalt meestal met dram (rum) of pandjes (doek) enz., zelden met geld.

\section{$\S 74$. Opnemen in de gemeenschap.}

Is bij een meisje de $8 \mathrm{e}$, bij een jongen de $9 \mathrm{e}$ dag na de geboorte aangebroken, dan wordt het kind uit de donkere hut waarin de bevalling plaats vond, naar buiten gedragen, wat met een groote plechtigheid geschiedt; men noemt het ,poeroe na doro".

Vroeg in den ochtend komen reeds vrienden en familie en buren. Dan gaat een priester of oude naar de fragatiki, offert en smeekt den Granjorka's om het kind in hunne bescherming te nemen. Vervolgens gaat men naar de hut, waar vooral veel vrouwen op bankjes voor de hut zitten en een groote menigte rondom staat. De priester staat vooraan en heeft een flesch met water en een flesch rum bij zich. Eerst offert hij water (trowéi watra) en daarna rum als een bijzondere tractatie voor de geesten. Men spreidt een nieuwen lendendoek op den grond en nu kloppen de moeder en de tante van de bevallen vrouw aan de deuren, zeggend, dat de tijd daar is.

$\mathrm{Nu}$ komt de vroedvrouw met het kind, dat in de hoogte wordt geheven; de moeder en de tante strekken de handen uit, doch het kind wordt naar den anderen kant opgeheven; ten slotte krijgt een van beiden het. Het kind wordt op den lendendoek gelegd en er wordt een kleed over gelegd. $\mathrm{Nu}$ wordt de moeder van het kind uit het huis gehaald. Aan de hand van de vroedvrouw loopt zij twee of drie maal rond het huis en komt dan op een voor haar gereed gezet bankje voor de hut te zitten en ook zij wordt overdekt.

Thans gaat de priester aan den gang. Hij bestrijkt het kind met pimba en daarna met een uit kruiden bereide zalf die hij in een kalebasje heeft, roept alle goede geesten op om dit kind in hun heilige bescherming te nemen en draagt het op aan Khedi ama, Khedi ampon, den Heer der Hemelen en der Aarde, door het drie maal in 
de hoogte te heffen en daarna op de aarde neer te leggen. Hij spreekt ook het kind toe en zegt aan het kind, dat hij een goed mensch moet zijn en noemt de deugden op die men van hem verwacht en de ondeugden die ver van hem moeten blijven; in de eerste plaats mag hij geen ogri hatti (kwaad hart) hebben, dus nooit een wisiman worden.

Is dat afgeloopen, dan offert de priester ter plaatse aan alle jorka's. Het kleed wordt van de moeder weggehaald, ook van het kind en nu komen de geschenken. Heeft het huis welvarende vrienden, dan zijn die geschenken kostbaarder en talrijker; in den regel zijn het kleedingstukken en gebruiksartikelen. Hiermede is de plechtigheid afgeloopen. Vooral de vrouwen haasten zich het kind, ter kennismaking, op te nemen. Tot besluit wordt een tractatie, ook naar gelang van welvarendheid, rondgediend.

\section{$\S 75$. Jeugd en volwassenverklaring; kleeding.}

Hoeveel kinderen een vrouw ook krijgt, zelden voedt ze een daarvan van de geboorte tot den volwassen leeftijd zelf op. In de eerste levensjaren is het kind meestal toevertrouwd aan de grootmoeder van moederszijde, of aan die van vaderszijde of aan een tante (het kweekjes-begrip der stadsbevolking; Enc. 436, 2H 21-22, 747). De oom van moederszijde houdt toezicht en gaat er zich meer mede bemoeien, naarmate het kind opgroeit. De opvoeding is er vooral op gericht, het individu weerbaar te maken voor het leven dat hem wacht. Kinderen mogen ook alle gesprekken bijwonen, ook die betreffende sexueele dingen en ze mogen vragen stellen en worden wel eens geëxamineerd. Zooals reeds gezegd, mogen bij een bevalling meisjes, hoe jong ook, tegenwoordig zijn.

Zoolang het kind nog jong is, tot 14 à 15 jaar, mag het moedernaakt rondloopen (foto's naaktheid en dragen kamisa, kwejoe of pangi, 3L I). De jongen krijgt daarna van zijn vader de kamisa (een tusschen de beenen door gehaalde lap van gestreept katoen, die voor en achter afhangt), waaraan geen plechtigheid verbonden is. Het meisje krijgt van een der grootmoeders of een tante de kwejoe (schortje van katoen). Daarbij wijst deze het meisje erop, dat die eenvoudige lap het symbool is van maagdelijke reinheid en dat op haar de plicht rust, dat steeds hoog te houden. (Die beteekenis van de kwejoe blijkt ook bij het gebruik, dat wanneer er op een dorp bezoekers komen van een bevriende lo of van een anderen stam, de 
jonge meisjes van het dorp kwejoe's spreiden over de banken waarop de jonge mannen zullen zitten, welke kzvejoe's hun bij vertrek ten geschenke worden geboden. Daarmede wordt uitgedrukt, dat de bezoekers met een rein hart werden ontvangen en hun gastvrijheid werd verleend en men hoopt, dat de aangeknoopte vriendschap onbesmet zal blijven). Doch elk volwassen meisje heeft, zoolang ze ongerept is, het recht de kwejoe af te leggen.

In 1907 zag ik op het Bonni-dorp Cottica een vrij groot aantal jonge vrouwen tegelijk geheel naakt rondloopen en gaf mijn afkeuring daarover te kennen aan den kapitein van het dorp, Bajo. Deze antwoordde: „Ho mineer, dati na weeti foe wi kondree”, och mijnheer, dat zijn de wetten van ons land. Hij legde mij toen uit, dat er niets schooners bestaat dan het lichaam van een vrouw; het is een geschenk van God aan haar, en zoolang zij onbevlekt is, is het haar recht daarmede te pronken. „Maar hoevele die zoo naakt gaan, hebben het recht daarop?”, merkte ik op. Bajo antwoordde: ,dat is dan een zaak tusschen haar en haar geweten; de vloek die haar daarvoor zal treffen, moet zij dan maar geheel voor eigen rekening nemen". - Tegenwoordig komt het steeds minder voor, dat volwassen meisjes naakt loopen.

Op den leeftijd van 18 à 22 jaar krijgt de jongeling officieel de kamisa. Daarvoor wordt een groote gebeurtenis in zijn leven gekozen, bijv. als hij een tijger schiet, zelfstandig een boot makt, die goed blijkt te zijn; enz. De oom van moederszijde biedt hem, zonder bijzondere plechtigheid de kamisa aan, of de vader doet het namens den oom. Daarmede is de jongeling volwassen verklaard en eerst nu mag hij een meisje ten huwelijk vragen.

Ik heb het bijgewoond, dat een jongeling voorman in een boot was, die een gevaarlijke stroomversnelling afvoer. Zijn koela (boomstok) raakte in een rotsspleet beklemd, doch bliksemsnel ging hij met de beenen wijd uitgespreid voor op de boot zitten en links en rechts trappend hield hij de boot vrij van de rotsen, zijn voeten te bloeden trappend. De boot kwam behouden beneden en een oudoom van den jongeling, die dat gezien had kwam naar voren, omhelsde zijn neef en viel aan zijn voeten neer, zeggend „bala, tidee mi gi joe kamisa” (broeder vandaag geef ik je de kamisa); hij greep naar zijn bagage, haalde er een kamisa uit en gaf die, met de woorden „bala loekoe joe kamisa, tidéi joe tron manningre" (broeder, zie je kamisa, heden ben je een man geworden).

Is bij een dergelijk geval niet een oom van moederszijde, doch 
wel de vader aanwezig, dan zal deze zeggen ,,jonge man, ik vraag de kamisa voor jou aan bij je oom".

[Mannen die zich netjes willen voordoen, dragen veelal een doek

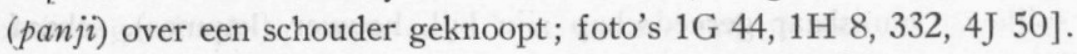

Een meisje dat nog de kwejoe draagt, heet kwejoeman. Wordt ze verloofd dan krijgt ze in de plaats van de kwejoe, de panji (op de wijze van een rok gedragen doek), wat met een plechtigheid gepaard gaat, waartoe de familie van haar aanstaande wordt uitgenoodigd. Het meisje is in de hut. Een priester brengt eerst aan de fragatiki de onmisbare offers aan de goden en Granjorka's. Nu wordt het meisje aan de hand van een tante of oude vriendin der moeder naar buiten geleid en men offert aan haar akra en haar ninseki, en er wordt haar voorgehouden, dat ze vandaag de kwejoe zal afleggen, dus als volwassen vrouw de maatschappij intreedt. De verplichtingen als volwassen vrouw en straks als moeder worden haar voorgehouden; de panji die ze zal krijgen, moet haar eerbaarheid dekken. Nu trekt de oude vrouw de kwejoe weg; enkele oogenblikken staat de maagd naakt; dan wordt haar de panji omgeslagen. Er volgen gelukwenschen en tractatie.

Het gebeurt wel eens, dat een meisje ouder wordt en niemand haar ten huwelijk heeft gevraagd; ze kan echter niet steeds als kwejoeman blijven rondloopen. Dan wordt haar met dezelfde plechtigheid de panji uitgereikt, maar met eenige meisjes tegelijk. Het komt voor, dat een meisje in het geheel niet huwt, en bij uitzondering, dat ze tot haar dood toe, maagd is gebleven.

\section{$\S 76$. Onderwijs.}

Iedere Boschneger is erop gesteld, dat zijn zoon geen wisiwasiman (onbeduidend mensch) wordt. Reeds vroeg ontvangt de knaap onderricht in datgene wat hij later noodig zal hebben om een zelfstandig lid van den stam te kunnen zijn. Hij moet goed met geweer kunnen schieten (de meeste Boschnegers houden het geweer met beide handen, doch de kolf niet tegen den schouder steunend) en met pij1 en boog visch kunnen schieten; vrij veel mannen kunnen ook met pij1 en boog wild schieten. Een man moet instaat zijn een huis te bouwen, een boot uit een boomstam te maken, en een boot op de rivier en in de watervallen te behandelen. Hij moet kunnen worstelen (hasoewa) en dansen en het is wenschelijk dat hij ook kan fluitspelen en hoornblazen en de trom kan bespelen. 
De jongens worden echter vrijgelaten om zich op het een of ander meer in het bijzonder toe te leggen. Zoo zijn er Boschnegers die bijzonder goed huizen kunnen maken, zelfs zonder een enkelen spijker. Onmisbaar gereedschap zijn bijl, houwer (kapmes), schaaf, hamer en pennemes; meer heeft men om een huis te bouwen, niet noodig. Anderen zijn gespecialiseerd in het bootmaken en daarvoor heeft men bovendien nog noodig een stel dissels om de boot uit te hollen. Allerlei dingen waar men het vroeger zonder kon doen, zijn echter tegenwoordig bijkans onmisbaar geworden, zooals passer, winkelhaak, boor, zaag, slijpsteen, spijkers. De jongens worden opgeleid door hun vader of ook wel door anderen, die bijzonder bekwaam zijn in het vak waartoe de jongen zich aangetrokken voelt.

De meisjes worden door de grootmoeder of tante die ze groot. brengt, in de eerste plaats onderricht in de kookkunst en in de kunst van een kostgrond beplanten (aan onderhoud van den kostgrond doet men niets), oogsten en kassavebrood bereiden. Zij leeren ook sepoe (kuitband) breien en naaien. De ouderen spinnen nog katoen, de jongeren koopen het alles. Het meisje moet ook leeren dansen, want bij vele godsdienstige plechtigheden is de dans verplichtend (nader 1L 101).

In oude tijden, toen de Boschnegers nog geheel geïsoleerd leefden, bereidde men zelf zout. Maanden lang was men bezig met kappen van palmboomen en haalde daaruit de palmiet (groeitop). Vervolgens verzamelde men hout dat goed brandt, legde op een rotsplaat een vuur aan en legde de palmieten daarop, die tot asch verbrandden. De asch werd in water gedaan en het water verdampt, waarna het zout overbleef. Voor een kleine hoeveelheid zout moest men zeer veel palmiet verbranden.

Ook bereidde men zeep uit een agave, de iendji sopoe (Indianen zeep). Men maakte diepe inkervingen in de bladeren en ving het uitvloeiend sap op in kalebassen. Dit werd aan de zon blootgesteld en nu en dan omgeroerd en er bleef een weeke massa achter, die zeepeigenschappen had.

\section{§ 77. Relieftatoeage.}

Dagboek d. G. 10 Nov. 1907 Djoeka-dorp Granbori, Tapanahoni. Heden in den voormiddag werd op drie jonge mannen, door vrouwen kotkoti aangebracht. Men brengt eerst het patroon aan, door witte stippen te geven met een stokje, gedoopt in pemba met wat water. Dan worden met een scheermes de sneetjes gegeven, waarbij men de 
huid tusschen duim en vinger wat samenknijpt. Dan afwasschen met katoenblaren die men uitknijpt en vervolgens inwrijven met houtskool. Idem 1904 uitleg van eenige Djoeka's. Het aanbrengen der kotkoti geschiedt op ongeveer 12-jarigen leeftijd of ook wel later en om goed te blijven moet het zoo nu en dan herhaald worden. De figuur genaamd gaté (zie 1P Am. Congres XXIV, ook id. XVI ngaté) geeft de plaats aan waar een man de vrouw moet wrijven bij den coitus; de vrouwen maken dit wel op binnenzijde dijen en vlak boven den venusberg omdat het aangenaam moet wezen als het daar ruw is.

SAR 1H 27, 31, 32, 223 vlg. en Eilerts de Haan 111-112 waar duidelijk de erotische bedoeling van verschillende tatoeages blijkt.

Foto's 3L II plaat III, OW 69, Vandercook 147, 185, 241, Holdridge 216, 217, Bonaparte.

\section{$\S 78$. Verloving en huwelijk.}

Bij de verloving komt veel poëzie te pas. Een jonge man is bijv. verliefd op een meisje van een ander dorp. Hij tracht dan vriendschap te sluiten met jonge mannen van dat dorp en komt zoo in kennis met het meisje en tracht in de gunst te geraken door haar cadeautjes te geven. Bemerkt hij, dat ze hem niet ongenegen is, en durft hij de vraag te wagen, dan laat hij door een kleinen jongen de boodschap aan haar brengen, of ze zoo goed zou willen zijn, zijn haar te vlechten. Is ze daartoe bereid, dan heeft hij hoop, maar nog geen zekerheid; die zekerheid krijgt hij pas, als het haar gevlochten is. Hij gaat met zijn haarkam naar haar toe; geen van beiden rept een woord en het kapperswerk wordt verricht. $\mathrm{Nu}$ haast onze jonge man zich, nadat hij haar bedankt heeft, naar vrienden aan wie hij zijn geheim verteld had, toont zijn hoofd en vraagt ,wat heeft zij gezegd?" Enthousiast zullen de vrienden hem dan gelukwenschen, omdat in het vlechtsel een motief te zien is, dat het jawoord beteekent.

Door de wijze van vlechten kan echter ook worden uitgedrukt, dat het meisje nog wil afwachten, en het kan ook zijn, dat de kenners van de soort van vlechten van het haar onmiddellijk zien, dat het meisje hem niet wil hebben.

Het kan ook zijn, dat de verliefde jongeling aan het meisje een door hem gesneden kam of paritiki (pagaaier-stok, dienende tot roerspaan). Het meisje vraagt dan aan een vertrouweling: „lees voor mij, wat hier staat", n.l. wanneer zij daar zelf niet toe instaat is. 
In het snijwerk is als motief de liefdesverklaring uitgedrukt. Aanvaardt het meisje het geschenk, dan is dat het jawoord.

Zijn de jongelieden het eens geworden, dan zal de jonge man zoo gauw hij maar kan, zijn tioe (oom van moederszijde) daarvan in kennis stellen en diens steun en medewerking vragen. De oom brengt de moeder van den jongen man en de familie van moederszijde, vervolgens ook die van vaderszijde, op de hoogte en gaat naar het dorp van het meisje en, stelt zich in verbinding met haar oom en nu beginnen de besprekingen. In den regel vinden zulke ernstige dingen plaats tusschen 3 en 5 uur in den ochtend. Is het dorp ver, dan gaat de oom speciaal hiervoor er logeeren.

Hij kondigt zich aan door keelschrapen, waarop geantwoord wordt „ja, soema dé” (ja, er zijn menschen). Met vele plichtplegingen voor het storen in de rust enz. zegt hij ,,mijn tong ligt op het oogenblik in de hangmat; ik kan niet spreken, zoo'n gewichtig ding als het is, waarvoor ik ben gekomen". Enz. En nu vertelt hij, hoe hij, wetend hoe minderwaardig hij is, tegenover de familie bij wie hij aanklopt, over iets gewichtigs komt praten. Zeker een half uur vergaat met plichtplegingen, alvorens hij met de zaak zelve voor den dag komt.

Hoewel het oordeel der vrouwen minder telt bij de Boschnegers, hebben bij een aangelegenheid als het uithuwelijken van een dochter, de vrouwen, moeder en tantes, de beslissing in handen.

Is de toestemming verkregen, dan komt de oom terug in een raad der familie van het meisje, vergezeld van den jongen man en enkele ouderen uit diens familie. Weder wordt het verhaal gedaan. En nu leggen de vrouwen van de familie van het meisje aan de vragers de tekortkomingen, de chronique scandaleuse, van de familie van den jongen, voor.

Is men het ten slotte eens geworden en is de verloving er door, dan wordt door de familieleden van het meisje de dag bepaald voor het "poti na hoso" (het de vrouw in een huis zetten) en worden familieleden en vrienden uitgenoodigd. Weken of maanden tevoren heeft de jonge man, geholpen door zijn vrienden, op het dorp van zijn aanstaande een huis voor haar gebouwd en hij en zijn familie hebben huisraad, kookgerei enz. gekocht of gemaakt. Van den kant der bruid worden ook geschenken aangeboden. Vriendinnen van de bruid belasten zich met het in orde maken van de woning.

Op den dag van het huwelijk is er een groote kroetoe op het dorp van het meisje. De jonge man met zijn ouderen en verdere bloedverwanten en vrienden zijn den avond tevoren gekomen. Het meisje 
is niet bij de kroetoe aanwezig en de jonge man zit op een afstand op een bankje met den rug er naartoe; het is namelijk niet eerbiedig een oudere die je aanspreekt, aan te kijken.

In de vergadering worden opnieuw de familierelaties en de chronique scandaleuse opgedischt en of er wel pikadoe (bloedschande) is geweest in de familie van den jongen man. Er wordt niet tegengesproken, doch ten slotte verklaart een der ouderen van de vrouwsfamilie ,ja, maar ook wij gaan niet vrij uit"; en beleefdheidshalve vertelt hij nu van hun eigen zonden.

Zijn nu vele uren doorgebracht met wederzijdsche hoffelijkheden en ook hatelijkheden, dan zegt de oudste oom van moederszijde van het meisje ,nu zullen wij den jongen man zijn vrouw geven”, en de jonge man wordt gehaald van de plek waar hij zit, met een of twee boezemvrienden in de buurt. Hij voegt zich bij het gezelschap en gaat daar op een bankje zitten met den rug naar het gezelschap. Zijn eigen oom vertelt hem, dat hij het meisje tot vrouw heeft gekregen en wijst hem op zijn verplichtingen: hij mag zijn familie, en als het meisje tot een andere lo behoort, ook zijn lo geen schande aandoen bij de nieuwe familie waar hij bij gaat leven (hoewel hij daarmede niet overgaat tot de $l o$ van zijn vrouw en deze evenmin tot de zijne). De jonge man antwoordt nooit.

Dan spreekt een der ooms van het meisje den jongen man hoffelijk toe, zeggend hoe het meisje hem van ganscher harte wordt gegeven, en dat men erop rekent, dat hij voor haar een goede man zal zijn en, als er kinderen komen, deze goed zal verzorgen. Hij moet vooral niet vergeten, dat de vrouw onder hem staat en in geen geval mag hij, als man, toelaten dat zijn vrouw de baas over hem speelt. Zijn vrouw is verplicht hem te volgen waar hij ook gaat, op reis, op de jacht, bij het grondje vellen enz. en ze heeft hem te gehoorzamen. „Wordt ze brutaal tegen je, dan heb je als je gekleed bent, je buikriem bij je, en anders is een twijg gemakkelijk te plukken; ransel haar dan goed af, Zorg echter, dit nooit te doen als jullie maar met je beiden alleen bent, dus niet op afgelegen plaatsen of als je maar met je beiden in een boot op de rivier zijt. Zorg in elk geval, je altijd te beheerschen. Hatti bron no de meki boen pikien (drift baart geen goede kinderen) of hati bron de kiri joe, ma a no de bere joe (drift doodt je maar zorgt dan niet voor je begrafenis)".

$\mathrm{Nu}$ halt de moeder of een oudere tante het meisje in de kroetoe, aan de andere zijde als waar de jonge man is, en eveneens met haar rug naar het gezelschap. Haar oom, die de geheele vergadering geleid 
heeft, spreekt haar aan. Hij geeft haar een samenvatting van wat over en weer door beide families gesproken is, en op het laatste deel, de rechten van haar man op haar, legt hij bijzonderen nadruk. Dan neemt haar oom haar aan de hand en de bruidegom wordt naderbij geroepen, die dan niemand aankijkt, doch voor zich naar den grond staart, evenals zijn bruid. De oom zegt ,dat is jouw vrouw voortaan, je gegeven door de familie, je gegeven door den Granman (d.w.z. door den opperpriester)". Men offert aan de Granjorka's en er worden tractaties toegediend aan het gezelschap. De jonggehuwden verdwijnen ongemerkt.

Zoo'n huwelijksplechtigheid vindt niet plaats bij een jongedochter die geen maagd meer is, noch bij een gescheiden vrouw of man, weduwe of weduwnaar. Nochtans kan ook een tweede huwelijk niet tot stand komen zonder familieonderhandelingen als vorenvermeld en hetzelfde geldt, als een gescheiden paar weder bij elkaar wil komen.

De man en de vrouw die eenmaal gehuwd zijn, zijn en blijven mondig, behoudens in geloofszaken; tekortkomingen of vergrijpen tegen het geloof kunnen ongeluk brengen over de familie en zelfs over de $l o$ en gaan dus deze aan.

[Ko 400 vermeldt nog, hoe soms de familie van een meisje en die van een jongen, reeds vóór ze rijp zijn, afspreken, dat die twee een echtpaar zullen worden; de jongelui houden zich echter niet altijd daaraan; zie ook C14]

\section{§ 79. Voeding, nijverheid en handel.}

De huizen bouwt men zelf en bezigt daarvoor zelf gekwijlde planken van boomen uit het bosch en voor dakdekking bladeren van den tas-palm. Alleen de zeer modernen bezigen gezaagd hout en gegolfd plaatijzer voor dakdekking. Iedere Djoeka verstaat het, een kleine hut, een masanga, te bouwen. Voor een grooter en steviger huis, een hoso, roept hij veelal de hulp van een ander in, die daarin bedreven is, een timbreman (timmerman).

Er zijn Boschnegers die voor het afsluiten van het huis de voorkeur geven aan een houten negerslot (afbeelding Lindblom 21, Joest 59). Conservatieve Djoeka's houden er ook aan vast om hangmatten, eet- en kookgerei (houten nappen en bakken, lepels van kalabasschaal, aarden potten) en sieraden, zelf te vervaardigen, ook al kan men ze gemakkelijk in den winkel koopen.

De Djoeka meent, dat een mensch veel voedsel noodig heeft om 
gezond te blijven; en men eet overmatig veel en de kinderen worden van hun prille jeugd af reeds overmatig gevoed. Op de kostgronden plant men echter niet meer dan noodig is en bij den kleinsten misoogst is er dadelijk voedselschaarschte. De gegoeden koopen dan wel rijst, meel of beschuit in de winkels aan de Marowijne en Lawa of te Albina aan de beneden-Marowijne, waar de vrachtvaarders telkens komen. Daar schaffen ze ook zout, suiker, sterke drank, petroleum en wel eens blikjesconserven als lekkernij aan, en voort geweren en munitie, bijlen, houwers en alle overig ijzeren gereedschap, ook slijpsteenen, hoewel velen nog rotssteenen uit de rivier gebruiken. En voorts het doek voor kamisa's en pangi's, soms reeds genaaid; en ruilartikelen voor hun handel met de Indianen van het binnenland. Winkeliers te Albina geven degenen die bij hen inkoopen wel gratis logies. Geld verkrijgen de Djoeka's door de vrachtvaart en een enkel maal door hout kappen en een weinig door verkoop van de bij de Indianen van het binnenland verworven zaken. Bij die Indianen ruilen ze hangmatten, katoenen draad, bogen en pijlen enz.

Bogen en pijlen kan men zelf maken, doch liever betrekt men ze van die Indianen. Booten maakt men steeds zelf. Geld wil men alleen als zilvergeld hebben en bewaart het onder vloerplanken of balken, in trommels of bundels; heeft iemand veel geld, dan begraaft hij het in het huis.

Behalve plantaardig voedsel, gebruiken de Djoeka's ook vleesch en visch. Het wild schiet men meest met het geweer en men bezigt een jachthond, dien men zelf kan africhten, hoewel nog meer in tel zijn de afgerichte jachthonden die men door ruilhandel van de Indianen van het binnenland verkrijgt. De visch schiet men met pijl en boog of bedwelmt de visch $(\S 80)$; er wordt echter ook wel met den vischhaak gevischt, en men stelt vischvallen (baskita) van mandewerk met dichtklapdeksel.

Overigens heeft men weinig huisdieren. Er zijn wat kippen, die wel eens voor een feest geslacht worden; men eet ook wel de eieren. De kip is vooral noodig voor gelegenheden waarbij het bloed van een kip geofferd moet worden (bij kindersterfte bijv.); bij het ,gi akra njcjam" (de akra te eten geven) behooren eieren; de hanen gebruikt men om er een teeken uit te kunnen aflezen ( $\$ 30)$. Enkelen hebben een papegaai of een poes. 


\section{$\S 80$. Ponsoe.}

Ponsoe is het bemachtigen van visch, door ze te bedwelmen met het sap van de nekoe-liaan.

Een nekoe-plant in het woud is het eigendom van dengene die haar ontdekt heeft; deze stelt er een zichtbaar merkteeken bij, bijv. snijdt hij in een boom in de nabijheid een driehoek met de punt naar beneden, zijnde het teeken van zijn familie; of hij snijdt er een paar krabbels in, waaruit degene die de teekens kent, leest „deze boom is geveld", d.w.z. deze nekoe is zoo goed als geveld, een ander mag er niet aankomen. Men mag een nekoe-plant alleen voor zich reserveeren, als ze groeit op land van de eigen familie (zie $\S 1$ ).

Zal er een groot feest plaatsvinden, waarvoor men visch noodig heeft, dan biedt de eigenaar van een nekoeplant aan om te zorgen voor nekoe voor de vischvangst; of men vraagt hem dit. Dan worden menschen uitgenoodigd om de nekoe naar buiten te dragen en te vervoeren naar de plaats waar de ponsoe gehouden zal worden, meestal tusschen de watervallen der rivieren en in groote kreeken. Den middag tevoren is het ,fon nekoe", het kloppen tot vezels van korte stukken van het hout der liaan (foto $2 \mathrm{~K} 215$ ). De pulp doet men in oude korjalen en dekt ze af tegen regen.

Zeer vroeg in den ochtend wascht men iets bovenstrooms van de watervallen, de pulp in het rivierwater uit, zoodat als de dag is aangebroken, de visschen reeds bedwelmd zijn en men dan begint met de visschen te spietsen met stokken waaraan een stuk ijzerdraad of een spijker of een stukje hard hout is bevestigd; men schiet ze ook wel met pijl en boog, of vangt ze met de hand.

Iedereen, ook niet-Boschnegers, zooals balatableeders of gouddelvers die ter plaatse mochten zijn, mag mededoen aan het bemachtigen der visch, doch de eigenaar van de ponsoe, dat is de man of de familie die de ponsoe heeft aangelegd, veelal de eigenaar van de nekoe, mag van iedere deelnemende boot ten hoogste drie visschen voor zich opeischen. Daartoe heeft die eigenaar een groot aantal opzichters (basia) in bootjes, die rondgaan om de vangst te inspecteeren en het aandeel op te vorderen. De basia die een visch heeft opgeëischt, geeft een quitantie af in den vorm van een stuk van een boomblad. Als een onbevoegde zou beproeven op die wijze visch tegen quitantie te bemachtigen, dan herkennen de basia's zulks gemakkelijk, omdat zij alleen bladeren van een bepaalde soort gebruiken. Die bladeren zijn vlak voor het begin van de ponsoe aan de 
basia's gegeven, waardoor het niet mogelijk is, dat tevoren uitlekt, welke soort bladeren men gebruikt.

De visch in de rivier geldt als gemeengoed, in tegenstelling met de dingen die men in het bosch bemachtigt, waar iedere familie een eigen terrein heeft. Degene die een ponsoe zal houden, moet dit tijdig bekend maken; ,kibri ponsoe”, de ponsoe geheim houden, wordt als een schanddaad aangemerkt, waardoor de betrokkene zich aan de verachting der anderen blootstelt. Men kan er zelfs een rechtszaak van maken, wat wel eens is voorgekomen.

$\mathrm{Bij}$ het vervoer van nekoe langs bewoonde plaatsen, moeten de booten als kenteeken voorzien zijn van palmbladeren, die op een bepaalde wijze, rechtopstaand, in de boot geplaatst worden (foto $1 \mathrm{~F}$ 148) en in een boot heeft men een apienti-trom waarmede men in trommetaal kennis geeft van de nadering, of men waarschuwt met hoornsignalen. Een zwangere vrouw mag n.l. niet in aanraking komen met nekoe en zelfs niet naar een nekoe-boot kijken; zij moet zich dus schuilhouden als zoo'n boot aankomt. Want het kind dat zij draagt, zou door de nekoe vergiftigd worden en bovendien zou de nekoe zijn kracht, waarmede immers het kind is vergiftigd, verliezen. Het kan voorkomen, dat de gadoe van het kind sterk genoeg is om dit te beschermen, en het dus geen miskraam wordt; de nekoe heeft dan echter niettemin zijn kracht verloren.

Een menstrueerende vrouw mag de nekoe volstrekt niet aanraken; dat zou die nekoe bederven.

Dagboek d. G. 27 Nov. 1904. Sonie (een Djoeka dien wij tegenkomen) geeft aan Lebitetei (Djoeka, stuurman van mijn boot) een stuk nekoe; dit wil L. niet op z'n pagaal (doos van indiaansch vlechtwerk) laten liggen, daar het de hierin zittende obia zou bederven.

\section{§ 81. Ziekte.}

Bij de Boschnegers heerscht het geloof, dat geen enkele ziekte een natuurlijke oorzaak heeft. Bijv. een man valt en krijgt een kneuzing, waaruit een abces voortkomt. Wijst men den Boschneger erop, dat die kwaal een natuurlijke oorzaak heeft, dan antwoordt hij: , ja, het bezeeren en het abces zijn natuurlijk; maar de val moet een bovennatuurlijke oorzaak hebben". Zoo'n bovennatuurlijke oorzaak kan wezen, dat de man een gado tekort heeft gedaan, heeft gezondigd tegen de leer van Grantata, of dat er fiofio is; enz. Nog veelvuldiger komt voor, dat een wisiman hem het onheil heeft toegezonden.

Wie een ziekte wil genezen, zoekt dus het eerst naar de boven-

D1. 99. 
natuurlijke oorzaak daarvan. Het eerst wat men doet, is een offer plengen aan de Granjorka's of aan den gado van de streek waarin de zieke momenteel vertoeft. Bijv. een man heeft erge kiespijn. Hij verzoekt een der ouderen van het dorp, om voor hem een offer te plengen. Zijn bloedverwanten, vooral de vrouwen, vergezellen dengene die het offer zal plengen naar de fragatiki en ondersteunen het gebed dat die oudere doet, met handgeklap en den aanroep „grantanji baa gado (resp. Granjorka), joe moe teki na begi” (alsjeblief god of Granjorka's, verhoor het gebed). Verergert de ziekte, dan komt de priester-obiaman erbij te pas, zie $\S 36$.

Baat het alles niet, dan ziekt men als laatste redmiddel hulp bij Grantata. De hoogepriesters te Drietabbetje nemen het geval onderhanden; de heilige bundel wordt gedragen en zij trachten een uitspraak te krijgen ( $(30)$. Grantata geeft nooit materieele middelen aan, zooals kruidenbaden, doch schrijft offers voor, of het gedurende een bepaalden tijd wegblijven uit bepaalde streken.

Er zijn ook geneesmiddelen die men door overlevering kent en toepast, zonder dat eerst door magische verrichtingen de diagnose gesteld behoeft te worden. Bijv. tegen koorts, aftreksel van bepaalde bladeren, zweetbaden, onthouding van peper of zout, tegen wormen aftreksel van de bladeren van een boom; ook bloedstelpende middelen, middelen tegen impotentie en tegen geslachtsziekten (inwendig of uitwendig) kent men. Van het middel tegen impotentie is een onderdeel, de penis van een mannelijken schildpad. De recepten gaan over van ouders op kinderen; dat is ook het geval met inentingen : sneki-koti, sipari-koti ( $(59)$, koti tegen geslachtsziekten, speciaal gonorrhoe en bubo's.

In den loop der jaren hebben de Djoeka's ook kennis gemaakt met europeesche geneesmiddelen en thans zijn ze daar zeer op gesteld en ze laten zich ook in het hospitaal te Paramaribo behandelen en opereeren.

Syphilis heeft altijd bestaan bij de Djoeka's, doch men weet nog goed, dat deze ziekte meer algemeen is opgetreden, nadat aan de Lawa goud ontdekt was en de avonturiers, waaronder vele vrouwen, uit geheel West-Indië, daar kwamen. De Bonni-mannen kregen het van de beroepsprostituees onder die vrouwen; zij infecteerden de Bonni-vrouwen en de Djoeka's die als vrachtvaarders op de Lawa kwamen, kregen het van die Bonni-vrouwen (die wel geen prostituees zijn, doch het aardig vinden haar man te bedriegen) of van de prostituees. Zoo kwam het in de Tapanahoni. 
Krankzinnigheid komt betrekkelijk veel voor onder de Boschnegers. In de meeste gevallen meent men, dat de oorzaak is, dat de akra van den betrokkene verstoord is, en dat zulks teweeggebracht is door een wisiman. Die wisiman heeft door zijn toovenarijen het slachtoffer ertoe kunnen brengen, op de een of andere wijze zijn akra te verstoren; of de wisiman heeft hem zijn akra afgenomen en die op een plaats gedeponeerd waar het slachtoffer nooit weder in contact kan komen met die akra. De akra is dan in een doek gewikkeld en de wisiman spijkert dit pakje bijv. tegen een boom; of hij werpt het pakje, met een gewicht bezwaard, in het water. [STAD Iets dergelijks 1P 161]. De wisiman kan iemand ook een lau-bakroe, een krankzinnigen geest toezenden en zoo de krankzinnigheid veroorzaken $(\S 48)$. Het komt ook voor, dat de koenoe (§ 14) iemand krankzinnig maakt.

De Djoeka's probeeren in het algemeen niet om een krankzinnige te genezen. Is de krankzinnige doorloopend verward of lastig, dan brengt men hem op een eilandje, bouwt daar een hut voor hem en laat hem alleen, zonder boot. Voedsel wordt hem geregeld gebracht. Ontvlucht hij telkens, en wordt hij maniakaal, dan wordt hij in het dorp aan voetblokken geketend. Sterft hij, dan heet het „na Bakroe broko hen neki", de bakroe heeft zijn nek gebroken. Het lijk wordt behandeld als dat van een niet-krankzinnige, doch men doet een bijzonder onderzoek naar de oorzaak van de krankzinnigheid. Het komt ook wel eens aan het licht, dat de krankzinnige zelf een wisiman was en de krankzinnigheid een straf daarvoor.

STAD 1L 52 vermeldt: „Isri-wisi is het brengen van voorwerpen in het lijf van een ander. Ik heb arbeiders in het bosch ontmoet, die bezwoeren, dat zij naalden, geldstukken enz. uit hun lichaam of dat van anderen hebben zien halen". Zie ook 1P 164, 180 en vgl. 2H 107-108. In 1937 was er aan de Litani een surinaamsche Neger, goudzoeker, die aan maagpijnen of dgl. leed en zeide dat een Oajanavrouw hem wat ingegeven had; hij liet zich daarvoor behandelen door Oajana-medicijnmannen, waarvan er een, splinters van komboepalm te voorschijn bracht. De surinaamsche Negers noemen dit wel jorka peiri (jorka pijl), de engelsche Negers djombi peiri (geest pijl) en wellicht hebben de Negers dit begrip overgenomen van de Indianen, die het ,booze-geest pijl” noemen, en het samengekoppeld met het Negergeloof, dat men iemand een kwaadgezinden jorka toe kan zenden.

Zich lui uitrekken, hari lesi, mag men niet doen in de nabijheid 
van iemand die gelooft aan die dingen; want door die simpele beweging wordt aan hem overgegeven dat wat je neerdrukt, je hebi (zwaarte; vgl. 1P 165).

$\S 82$. Dood en begrafenis.

In gewonen doen slaapt een Djoeka wel eens op het in zijn hut aanwezige bed, doch als hij ziek wordt, gaat hij onmiddellijk op dat bed liggen, want het sterven in een hangmat zwevende, of in het bosch, is niet goed; hij moet sterven op het bed. Sterft hij op een andere plek, dan moet daarvoor een oorzaak zijn geweest. Men onderzoekt dat door ondervragen van den heiligen bundel of door een obiaman en de familie brengt offers om de goden te verzoenen.

Als het op zijn einde loopt, dan houden echtgenoote (bij overlijden der vrouw geldt mutatis mutandis hetzelfde) en naaste bloedverwanten om beurten wacht en ondersteunen den in zittende houding geplaatsten zieke van achteren. Een mensch mag n.1. niet in liggende houding sterven. Als het laatste oogenblik nabij is, dan is het meestal eivol in de hut met familieleden, dorpsgenooten en vrienden, die den stervende allerlei heilwenschen en boodschappen voor de andere wereld meegeven. Zoodra de dood is ingetreden, geeft men op de apienti-trom kennis aan de buurt, dat die en die overleden is.

Was de overledene een hoofdkapitein of andere hoogwaardigheidsbekleeder, dan wordt, vóór men met eenige ceremonie mag aanvangen, aan den Granman bericht van het overlijden gezonden. Deze vaardigt met bekwamen spoed drie hooge functionnarissen af, om den dood officieel vast te stellen. Bij aankomst op het dorp begeven zij zich regelrecht naar de hut waarin het lijk, met een laken overdekt, ligt. Het laken wordt weggenomen, de oudste der afgevaardigden gaat voor het lijk staan, en roept den overledene luide aan (gesteld dat deze Djinta heette): Da Djinta! (Vader Djinta!). Even wachten; nog luider: Da Djinta!; weer wachten en dan zeer luid: Da Djinta!; nogmaals wachten, en als ook nu geen antwoord komt, dan keert de afgezant zich tot de aanwezigen en zegt: Gransoema, da Djinta dede troe (ouderen, vader Djinta is werkelijk dood). Thans eerst mogen de lijkceremoniën beginnen; drie salvo's uit tientallen geweerloopen geven kond van het verscheiden en de apienti verbreidt de tijding over het geheele land.

Allen zijn verplicht hulp te verleenen bij hetgeen verder geschieden moet. Tot aan het uur der begrafenis verrichten de kisiman's (kistmakers) het werk, daarna de oroman's (lijkvervoerders). Kin- 
deren moeten als zij nog jong zijn, kiezen of ze tot de kisiman's of tot de oroman's willen behooren.

Men vervaardigt nu een papaai, dat is een bak of baar van gespleten stammetjes der wilde papaja (Cecropia), met lianen aaneen geregen. Het lijk wordt in een laken gewikkeld of met doeken omwikkeld en in dien bak gelegd. Twee mannen nemen den bak op en stellen zich daarmede buiten de hut op.

Dan komt een priester van Grantata, die het lijk, of eigenlijk de jorka van den overledene $(\S 8)$ toespreekt, zeggend ,nu moet ge gaan naar de Kréihoso ( $\$ 55)$, daar behoort het lijk van een goed mensch die overleden is, thuis". De dragers zetten zich in beweging en als zij regelrecht naar de fragatiki gaan en er een paar keer omheen loopen, dan is dat een zeer gunstig teeken en acht men het reeds vrijwel bewezen, dat de overledene geen wisiman ( $\S 48$ ) was. De Djoeka's zijn vast overtuigd, dat de dragers willoos zijn en door den geest (jorka) van den overledene bestuurd worden.

Vervolgens stelt de priester vragen aan den geest, die door hoofdbewegingen van den voorsten drager, of door het voor- en achterwaarts gaan, beantwoord worden met ,ja” of ,neen”. Daarna krijgt de geest de opdracht "foe poeroe soema na doro" (om menschen naar buiten te halen). Terwijl men namelijk bezig was het lijk op de papaai te leggen, hadden ouderen drie willekeurige personen elk in een hut, liefst op grooten afstand van elkaar, verborgen, zonder dat de dragers er iets van konden bemerken. De geest moet nu, na de fragatiki bezocht te hebben, regelrecht gaan naar de hutten ,pec wan soema kibri" (waar een mensch zich schuil houdt) en tegen de deur aanbonzen. Geschiedt dit vlot, dan zegt men tot den geest „kies uw plaats in de Kréihoso". Familie en vrienden juichen en er worden geweersalvo's gelost om kondschap te doen, dat de overledene rein gestorven is.

Als daarentegen de overledene een erge wisiman was, dan zal het lijk de fragatiki niet kunnen bereiken. De dragers staan plotseling stil en rennen dan het bosch in. En al gelukt het aan het lijk (den geest) om de fragatiki te bereiken, dan zal het bij de tweede proef toch falen; het gaat naar verkeerde hutten, keert telkens terug, enz. Het kan uren, in bijzondere gevallen zelfs dagen duren, eer de ouderen die de leiding hebben, er genoeg van hebben en de jorka onderhanden nemen. In het nauw gedreven, zal ze moeten bekennen. Het lijk wordt vervloekt, doch daar het wel eens later zou kunnen uitkomen, dat de overledene geen wisiman is geweest ( $§ 48)$, spreken 
degenen die het lijk vervloeken het „mi gi heroe” (ik geef heroe) uit, d.w.z. ,,verantwoording hiervoor neem ik niet op mij”. Vervolgens wordt het lijk in een bouwvallige gesloten hut gelegd, soms ook in de open lucht, in weer en wind, tot hoon en spot van elkeen. Daarna wordt het weggeworpen en de hut van den overledene wordt geslecht. Zijn voorwerpen van dagelijksch gebruik worden weggeworpen, de meer waardevolle bezittingen worden ingeleverd te Drietabbetje voor Grantata.

[2K 210-212 vertelt van een man die door een vallenden boom was getroffen en stierf. Men vroeg aan de jorka ,heb je wisi?”„,neen”; ,heb je iets gedaan waarvoor Asigu (\$ 54) je heeft neergeslagen?” - ,ja”. Daarop werd de eveneens door twee man gedragen bundel van den god geraadpleegd, die rouw en muziek verbood, doch begrafenis toestond. Het lijk werd naar het bosch gebracht en in een kuil geworpen, waar meerdere geraamten lagen. Blijkbaar was dit een geval als vermeld in $\S 19$, evenals die welke Ko 399, 3J 155-156 en 4J 54 vermelden].

Als het onderzoek afgeloopen is en de verledene rein bevonden werd, haalt men de apicnti-trom voor den dag en speelt treurmuziek. Intusschen wordt het lijk naar de kréihoso gebracht en op twee blokken gelegd, waarvan dat aan het hoofdeinde hooger is dan het blok van het voeteneinde. De weduwe (als de vrouw stierf, de weduwnaar) wordt door de naaste bloedverwanten van den overledene naar de kréihoso geleid en neemt plaats aan het hoofdeinde van het lijk; zij moet daar blijven tot enkele dagen na de begrafenis, waartoe haar hangmat en verdere benoodigdheden naar de kréihoso worden gebracht. Bloedverwanten en nauwe vrienden voegen zich bij haar; al naar den stand van welvaart der familie wordt er kwistig of matig sterke drank rondgedeeld.

Elken ochtend tusschen 4 en 5 uur en elken avond tusschen 7 en 8 uur moeten de tijdelijke bewoners van de kréihoso luid en op zingende wijze weenen. Hoe luider geween, hoe dieper smart daarmede vertolkt wordt. In den nacht mag niet geweend worden, want dan zouden de rondwarende takroe jorka's, kwade geesten van overleden slechte menschen, het geween beschouwen als voor hen bestemd. Het tijdstip waarop men in het dorp mag beginnen te weenen, wordt 's ochtends door een geweerschot aangekondigd.

De kisiman's zijn dadelijk begonnen met de lijkkist te timmeren. Planken maakt men in het bosch en bekapt ze daar met de bijl. Doch meestal heeft de familie reeds planken, of kan die van vrienden 
bekomen; want elk familiehoofd dat zichzelf respecteert, zorgt dat hij altijd planken in voorraad heeft. Is de kist gereed, dan volgt het ,poti na kisi" (in de kist leggen), nadat het lijk ontwaaid (afgelegd, gewasschen) is. De kist is in den regel veel grooter dan het lijk, om ruimte te laten voor de vele geschenken die familie en vrienden medegeven en de gebruiksartikelen waarop de overledene bijzonder gesteld was. De kist wordt opengelaten, zoodat een ieder nog het lijk kan zien en tot het lijk (eigenlijk de jorka) kan spreken. Naar gelang de overledene in meer of in minder aanzien stond, zijn de geschenken die aan het lijk gebracht worden, talrijker of minder talrijk. Het zijn meest kleedingstukken (kamisa's voor een man, pangi's voor een vrouw, kwejoe's voor een maagd), hoofddoeken, slaaplakens, hangmatten, muskietengordijnen, doch ook wel tabak, sterke drank, of zelfs contant geld. Niet al deze dingen gaan mee in de kist; wat niet meegaat geldt als nalatenschap waarop de familie van moederszijde van den overledene aanspraak heeft. Een deel wordt aan kisiman's en oroman's als belooning afgestaan.

Toen bewezen was, dat de overledene geen wisiman was geweest, begon men met den doodendans, toeka geheeten, en dit gaat met tusschenpoozen door zoo lang het lijk boven aarde is, ook al duurt dat weken. In een grooten kring gaan de dansers om het lijkhuis (1F 145, Ve 323, bij Bonni's, in het huis rond de kist), achter elkaar op de maat van de trom handen en voeten, ja het geheele lichaam in rhytme bewegend, daarbij treurzangen zingend. Vooral de kinderen doen dit gaarne; voor hen is het bijkans een spel.

Men ondervraagt het lijk, door twee dragers gedragen, ook omtrent het leven van den afgestorvene en vooral omtrent de oorzaak van zijn dood (zie voorts § 48). In 1882 werd het lijk van Granman Blijmoffo en in 1915 dat van Granman Oséisi ondervraagd omtrent zijn opvolger. Deze Granmans hadden weliswaar bij hun leven hun opvolger aangewezen, doch er waren kapiteins wien de keuze niet beviel en die twijfel opperden of de overledene zich wel genoeg rekenschap had gegeven wat hij deed. Men redeneert: „Een mensch is feilbaar en is aan den invloed van anderen blootgesteld. Hij heeft hartstochten waardoor hij onrechtvaardige handelingen kan plegen. Een geest daarentegen is heilig en staat boven alle invloeden verheven, daarom kan hij verandering brengen in hetgeen hij als mensch verkeerd gedaan had" (1L 40 vlg., 57 vlg., en zie nog Ho I 270 en Hoofden verkiezing 591).

Het lijk verspreidt al spoedig een onaangenamen geur en er druipt 
vocht uit, dat wordt opgevangen. In vroeger tijden baadden zwangere vrouwen zich met dat vocht, waardoor het kind dat ter wereld zou komen de deugden van den afgestorvene zou erven. [W. L. Loth 84: De Aucaners verbeelden zich, dat zij met de ontwijkende gassen ook de goede hoedanigheden van den overledene inademen; Saramakkaners 4J 55 een toovenaar stort lijkvocht in de rivier met opdracht aan de jorka om een vijand te dooden]. Het lijk wordt soms zeer lang boven de aarde gehouden; dat van Granman Oséisi wel drie maanden. Om het lijk te conserveeren, droogt men het op een barbakot, zooals men dit met wild of visch doet.

Is men zoover klaar, dat van het lijk (de jorka) alles vernomen is, wat men wenscht te weten [vgl. nog Stn II/2/55], dan wordt de dag der begrafenis bepaald en nu treden de oroman's in functie; er zijn er meer of minder, naar gelang van het aanzien waarin de overledene stond. Evenals het maken van de kist, heeft ook het delven van het graf een feestelijk karakter. In vele booten gaan de oroman's, met schoppen en pikaxen gewapend, naar de begraafplaats. Veelal houden zij eerst, onder het lossen van geweersalvo's, vlak voor het dorp een bootenwedstrijd, waarbij op de apienti wordt gespeeld en men toepasselijke liederen zingt. Voor het eten der kisiman's en oroman's wordt, gedurende al de dagen dat zij op het dorp zijn, door de familie van den overledene gezorgd.

Het delven van een eenvoudig graf vordert soms meerdere dagen en krachtens een oude traditie zijn de oroman's, als ze op weg naar de begraafplaats zijn, baas op de rivier, d.w.z. ze mogen elke boot, behalve als er Europeanen of creolen als passagier in zitten, aanhouden, de eetwaar die er aan boord mocht zijn, confiskeeren en de opvarenden dwingen met hen mede te gaan, althans tot aan de landing der begraafplaats. De gedachte die hierbij voorzit is, dat elk lijk begraven móet worden en de verplichting daartoe op de geheele gemeenschap rust.

Op den dag der begrafenis wordt het lijk nogmaals ondervraagd, meestal daarover, of de lijkdiensten en geschenken naar tevredenheid zijn. En nu dragen de kisiman's de lijkkist naar de boot, in een langen optocht waaraan alle op het dorp aanwezigen deelnemen, onder het zingen van treurliederen of het uitspreken van gebeden, terwijl men nog boodschappen medegeeft aan overleden familieleden of vrienden.

Men plaatst de kist in een groote boot en aan het hoofdeinde nemen de klaagvrouwen plaats; dit zijn dorpsgenooten, doch geen familieleden. Er wordt een geweersalvo afgegeven en men steekt van wal. 
Er wordt eerst een soort waterfeest gehouden, waarbij de booten groote bochten op de rivier beschrijven en wedstrijd houden. Dan gaat men naar de begraafplaats, terwijl van de landing een laatste salvo weerklinkt. De klaagvrouwen beginnen haar klaaggeween onder begeleiding van de apienti en op alle bewoonde plaatsen waar de stoet langs komt, moeten de vrouwen aan den oever komen om mede den doode te beweenen.

Bij een onvermogende, of iemand zonder familie, geschiedt dit alles met minder luister, doch de plechtigheden moeten gehouden worden, want anders zou de jorka als dwaalgeest achterblijven en veel last veroorzaken. Bieden er zich geen klaagvrouwen aan, dan wijst de Basia van het dorp $(\S 1)$ er twee aan. De kosten van de begrafenis worden dan door het dorp gedragen en men spreekt, evenals te Paramaribo, van een ,lantiberi” (lands-begrafenis).

Elke lo heeft zijn eigen begraafplaats, uitgezonderd de Otterlo en de Misidjan, die samen doen. De begraafplaatsen liggen altijd op grooten afstand van de dorpen, en op het vasteland. Voor het wegwerpen der lijken van wisiman's zijn er twee bepaalde plaatsen aangewezen, een voor de opo- en een voor de bilo-negers.

Dagboek d. G. 14 Aug. 1903 te Manlobbi aan de Tapanahoni. In een hut hoorden we luid weenen - voor den 13 dagen geleden gestorven kapitein! Vanavond zou daarvoor een z.g. broko dét gehouden worden: dansen bij de trom tot daglicht; dit moet n.l. in zoo'n geval geschieden 8 à 14 dagen na 't overlijden. Id. 15 Aug. We zagen ook het ronddragen op een plank die 2 man op de schouders droegen, van zaken die aan den gestorven kapitein behoorden, waarbij verschillende vragen werden gesteld die dan door een lichten knik van de door 's kapiteins geest bestuurde hoofden der dragers beantwoord werd. Dit gebeurt ook met het lijk zelf, dat dan o.a. zoo zijn opvolger benoemt. Het lijk blijft 1-3 weken boven den grond en wordt tegen 't bederf op een rooster een weinig gerookt. De sappen die eruit loopen worden opgevangen en met kruiden vermengd door de mannen op 't lichaam gestreken: „om sterk te worden". De begrafenis geschiedt zeer netjes in een mooie kist die precies in 't graf moet passen; de stank is dan afgrijselijk. Over de gleuf waarin de kist past worden stokken gelegd waarop blaren, en daarop komt een laag aarde. Id. 4 Sept. Er is daar [in het tweede dorp] een doode, die volgens gewoonte reeds eenige dagen boven aarde staat - en vooreerst nog, niet begraven wordt. In de hut waarin op een paar planken met doeken overdekt het lijk lag, zaten 
vrouwen te huilen (d.w.z. huilgezang, geen echt schreien) en de lucht van dram [rum] bewees dat men trachtte de onaangename geuren van den afgestorvene wat minder te genieten [zie ook $1 \mathrm{~F}$ 51, 59-60]. Verder wordt op de trom geslagen en 's avonds en 's ochtends eenige losse geweerschoten afgegeven.

\section{§ 83. Potti na blakka en Poeroe blakka.}

Op den derden dag na de begrafenis moet een spijsoffer, trowéi njanjan plaats hebben, liefst veel, want de jorka van den overledene voor wien het bestemd is, is vergezeld van vele andere jorka's, bij wie ze straks te gast zal gaan, als deze van hun nabestaanden een spijsoffer ontvangen. Telkens, na korter of langer tijd, wordt dit herhaald. Ik heb zelfs gevallen medegemaakt van trowéi njanjai voor menschen die al langer dan een menschenleeftijd dood waren. Zie voorts $\S 84$.

Zij die bij het lijk in de kréihoso verblijf hielden, blijven daar tot een of twee dagen na het trowéi njanjan, doch mogen, als ze willen, ook langer blijven. De weduwe (weduwnaar) is verplicht gedurende tenminste een maanjaar van twaalf maanden te rouwen. De familie van den doode zet haar (hem) in den rouw, hetgeen potti na blakka (in het zwart zettei) heet. Op den dag na de begrafenis wordt zij (hij) uit de kréihoso naar buiten gebracht, [Ko 394 aan den oever der rivier gewasschen], de oudste familieleden nemen rondom plaat; en houden haar (hem) voor, welke plichten de rouw inhoudt; vooral geslachtsgemeenschap gedurende dien tijd brengt kwaad over de familie, of zelfs over de geheele $l o$.

Het haar wordt afgeknipt, de witte band die dadelijk na het overlijden om het hoofd was gedaan, wordt vervangen door een nieuwe; de rouwdragende krijgt een pandji als een nonnekap op het hoofd en een staf in de hand, mag zonder kap en staf niet uitgaan en moet dan naar den grond kijken en met den staf gelijk een blinde tasten. De hut mag slechts verlaten worden voor bad en natuurlijke behoefte, en onder geleide van een bloedverwant van de(n) overledene, die voor bewaking en bediening is komen inwonen. Als kap en staf gegeven zijn, offert men aan den geest van de(n) overledene en vraagt dezen de(n) rouwdragende te steunen gedurende den rouwtijd.

Het geheele jaar moet de rouwdragende af en toe weenen, gedurende de dipi braka (diepe rouw) die drie maanden duurt, twee keer per dag. Men neemt aan dat de geest van de(n) overledene voort- 
durend bij de rouwdragende is; deze moet bij alle eten een deel naast zich op den grond leggen, zeggend ,broer (zuster) hier is ons eten, laat ons eten", en evenzoo van alle drinken wat op den grond uitstorten. Scheren en knippen mag slechts door een bloedverwant van $\operatorname{de}(n)$ overledene worden verricht. De weduwnaar moet blijven op het dorp der vrouw.

De rouwdragende mag niet werken en wordt gevoed op kosten der familie van de(n) overledene.

$\mathrm{Na}$ drie maanden kunnen de bloedverwanten, die daartoe bijeenkomen, den rouw verlichten; de kap wordt afgenomen en de staf met plechtigheid in tweeën gekapt. Maar de familie kan den tijd van drie maanden rekken door onder het een of ander voorwendsel niet te komen. En er zijn ten deze liberale en conservatieve families.

Poeroe blakka, het zwart wegnemen, is het opheffen van den rouw. In den regel geschiedt het bij meerderen tegelijk, waardoor degenen die het eerst in den rouw kwamen, langer hebben te wachten. Het heeft het karakter van een feest.

Degenen die het poeroe blakka zullen ondergaan, verzamelen zich op het dorp waar het feest gehouden zal worden, de vrouwen onder geleide van oudere vrouwen, de mannen onder geleide van oudere mannen. Op afzonderlijke plaatsen aan de rivier krijgen zij een bad, waarbij degenen die daarmede belast zijn, gebeden en dankzeggingen uitspreken. Het rouwgoed wordt hun afgenomen en de familie van de(n) overledene biedt hun ander goed aan, waarmede zij terugkeeren naar hun dorpen. In daarvoor aangewezen hutten worden ze in feestgewaden gestoken, waarbij schelle kleuren domineeren. Nu wordt receptie gehouden, gedanst en feest gevierd.

Als de man zijn overleden vrouw mishandeld had, of haar ontrouw is geweest (of omgekeerd de vrouw), dan kan de familie van de overledene den rouw weigeren. Heel hoffelijk zegt men „beschouw het, alsof je kort voor haar dood gescheiden was".

De betrokkene en zijn familie zullen daarin echter niet berusten, want daarmede staan ze bloot aan de wraak van den geest van de overledene. Ze trachten de weigerachtige familie te overreden en gelukt dat niet, dan gaan ze in beroep bij den dorpsraad en eventueel bij de lo of zelfs bij den Granman. Het is nog nooit voorgekomen, dat in hoogste instantie de rouw geweigerd werd.

De Granman zelf behoeft nooit in den rouw te gaan; immers, zou dat hem verhinderen zijn functie uit te oefenen. 


\section{§ 84. Broko déi.}

Broko déi beteekent ,,(feest tot) het aanbreken van den dag”, en men duidt hiermede aan het feest dat gehouden moet worden om den geest van den overledene rust te geven. Bij de Djoeka's vindt het plaats als na een jaar de rouw wordt afgelegd, soms ook wel eerder, bij de Bonni's drie dagen na den dood. Het feest is meer of minder omvangrijk naar gelang van den welstand van de familie, doch zelfs voor de armsten moet een broko déi worden gehouden, waarbij dan enkele vrienden of kennissen uit naastenliefde voor de tractatie zorgen en dansen.

De broko-déi vangt 's avonds 6 uur aan met water offeren aan de fragatiki, terwijl het vuur ontstoken wordt. Jonge mannen hebben tevoren groote hoeveelheden brandhout verzameld; een der ouderen steekt het vuur aan; men spreekt de jorka's aan, die volgens de Djoeka's in drommen staan te kijken, en zegt dat het feest te hunner eere is en het licht van het vuur niet alleen dient om de menschen licht te geven, doch ook hun. De opvatting is, dat de dans, drank en voedsel een tractatie zijn van de nieuw gekomen jorka aan de reeds aanwezige jorka's.

Bij den broko déi behoort ook het vertellen van anansitori's en laitori's. De anansitori's zijn verhalen waarin Anansi, de slimme spin, de hoofdrol speelt. Anansi wordt door de Djoeka's als een godheid beschouwd en het vertellen van die verhalen is een vereering van Anansi, want ze kunnen niet zonder Anansi. (§ 29). Een laitori is een raadsel (zie Penard Negro riddles en $2 \mathrm{H} 433$ vlg.).

Dien eersten avond wordt aan de gasten een kleinigheid aangeboden, bijv. een stuk kassavebrood met een stukje visch, en men begint met de laitori's en anansitori's, waarmede vooral de jeugd zich bezig houdt. Om 9 à 10 uur begint dan de dans ( $\$ 53$ foto's $2 \mathrm{~K}$ 213) terwijl men doorgaat met de anansitori's; wie wil rusten van den dans voegt zich daarbij. Wie zeer moe is en wat gaat slapen, sluipt weg, want het strekt hem niet tot eer, dat hij zoo weinig uithoudingsvermogen heeft.

Als, den tweeden dag, de zon goed op is, stoppen de trommen; de menschen zijn moe en veelal beschonken en men brengt den dag door met rusten en slapen. Hoogstens wordt er 's avonds nog een anansitori verteld, doch dat is niet verplicht.

Den derden dag, namiddags omstreeks 5 uur geschiedt de plechtigheid van het trowéi zvatra (\$ 60). Dit geschiedt niet bij de fragatiki, 
doch bij de Kréihoso, het rouwhuis, dat nabij de fragatiki staat. Met dit offer wordt de jorka van den overledene opgedragen aan de welwillendheid van de andere jorka's, die hem zijn voorgegaan. 's Avonds wordt er gedanst en wat ge-anansitoried, doch het is niet van belang.

Den vierden dag omtrent 5 uur vindt het trowéi nj'jam plaats. De vrouwen brengen schotels eten naar de fragatiki en zetten die daar neer; iedere vrouw stelt er een eer in, den een of anderen schotel te kunnen aanbieden. Langs de kréihoso zijn bananenbladeren op den grond gelegd, naar gelang het een rijkere of een armere is, meer of minder bladeren. De Djoeka's stellen zich voor, dat de jorka's uitgenoodigd zijn tot het feest en spijsoffer, door het waterplengen, waarbij hun daarvan kennis werd gegeven. Ze zijn in grooten getale gekomen.

De oudste priester in jaren leidt de godsdienstoefening. Er wordt dank gezegd aan degenen die het eten gebracht hebben; de aandach: van de Granjorka's voor wie de spijs bestemd is, wordt erop gevestigd, met welke liefde aan hen geofferd wordt; er wordt gebeden, dat zij den overledene zullen opnemen en het feestmaal zullen beschouwen als door hem aangeboden; en men plengt water en sterke drank.

Bij de aangeboden spijzen mag schildpadvleesch niet ontbreken (§60). Ik vernam, hoe eens, op Drietabbetje, een brokodéi gehouden zou worden, maar men kon geen schildpad vinden. Er werd besloten het feest toch te houden. Tegen den ochtend begonnen de dansers zich terug te trekken, tot er slechts één overbleef. Toen bemerkte men, dat het de jorka van den overledene was, die daar danste; en al dansende steeg die ten hemel. Men verklaarde het aldus, dat door het ontbreken van schildpadvleesch de jorka in de war was gebracht en ze zich manifesteerde om daaraan uiting te geven. Het verhaal werd mij verteld door Aganga, een der vooraanstaande Djoeka's. Op mijn vraag hoe het mogelijk was, dat hij zoo iets kon gelooven, antwoordde hij: ,ik geloof het, omdat mijn vaderen het geloofden en mij in dat geloof hebben grootgebracht. U gelooft het niet, omdat uw vaderen het niet geloofden en $\mathrm{u}$ dus niet in dat geloof bent grootgebracht.

$\mathrm{Nu}$ wordt de helft van al die spijzen op de bananenbladeren uitgespreid. Er heerscht plechtige stilte. De onzichtbare geesten eten de kraka, het onzichtbare geestelijke van de spijs (Inl. 6).

De jeugd wordt al ongeduldig, en dan klinkt ineens het bevel 
„garboe!” (grijp) en allen vallen aan. Ieder werpt zijn blikje over een portie en wat hij daaronder heeft, neemt hij mede.

Een tot vier dagen later houdt men nog het feest van seti tafra, de tafel arrangeeren, het feest voor de gasten. Om 3 à 4 uur des namiddags brengt men kleine tafeltjes bij elkaar en iedere vrouw van het dorp brengt een schotel spijs, veel of weinig, naar vermogen, en plaatst dien op een tafeltje. Wederom is er de plechtigheid van het aanroepen der Granjorka's aan de fragatiki en wordt een tijdje gewacht tot de geesten het onzichtbare van de spijzen gebruikt hebben. Dan verdeelen de ceremoniemeesters, basia geheeten $(\S 1)$ de tafels, waarbij op de rangen gelet wordt. Het toegedeelde wordt aan den gast voor wien het bestemd is, bezorgd aan de hut waar deze logeert en daar eet hij het op. [Zie ook 2F 82-83 en Ve 322, 325 met foto tafeltjes].

Dien avond is er alleen maar dans, als de jongeren er lust in hebben. Den daarop volgenden avond wordt er nog eens gedanst en den volgenden ochtend is er het kisi hoso (het huis in beslag nemen). Het zijn meestal de jongeren, die dansende met trom en blik slaan en juichende door het dorp trekken. Voor iedere woning komen ze staan dansen en zingen en voeren verschillende dansfiguren uit en de bewoner van het huis is verplicht te tracteeren, in den regel op drank. Men juicht en plaagt elkaar; er wordt gestoeid en gehost tot namiddags 6 uur.

Den dag na de kisi hoso is het uur ,foe wakaman prati" (voor de gaanden, de reizigers, om te scheiden), waaraan een plechtigheid voorafgaat. Er móet een groote kroetoe (vergadering) gehouden worden bij de fragatiki, waarbij allen die deelgenomen hebben aan het feest, tegenwoordig moeten zijn. Nadat er geofterd is aan de Granjorka's en hun bijstand is gevraagd voor de oprechtheid van de ouderen die in deze kroetoe voorgaan en ook voor de andere aanwezigen, richt de oudste in jaren zich tot de menigte. Hij wijst erop, dat een groot feest ten einde is, dat ten doel had, het zieleheil van een of meer geliefden te verzekeren (een broko déi wordt soms wel voor 6 of 7 dooden tegelijk gehouden). Het zou daarom eeuwig jammer zijn, als op een of andere manier iets onaangenaams geboren op het feest, grooter afmetingen zou krijgen. Daarom worden de aanwezigen uitgenoodigd om, als ze iets op het hart hebben, daarmede onbewimpeld voor den dag te komen. Men kan op een of andere wijze misschien gezondigd hebben tegen de gasten; er zijn van verschillende dorpen families gekomen; een jonge man heeft 
misschien de jonge vrouw van een ander met een begeerig oog aangekeken; enz. Deze dingen nu, zijn even zoovele aanleidingen tor eventueele ruzie en geschil. De eer van de familie die deze broko déi heeft aangeboden is er echter mede gemoeid, dat de afrekening onmiddellijk in der minne geschiedt.

Bij deze afrekening zegt men elkaar soms ongezouten de waarheid en dikwijls worden ze ook met een grap verzoend. Het zou den gasten niet tot eer strekken, wanneer, nadat zij de plaats verlaten hebben, er nog onaangenaamheden besproken zouden worden.

Is deze kroetoe afgeloopen, dan gaat men naar de fragatiki, er wordt weder een dankoffer gebracht en het feest is afgeloopen. De gasten worden wel eens gevraagd nog een nacht over te blijven, doch men komt voor deze broko déi niet meer aan de fragatiki.

[Ko 395-396. Bij de Saramakkaners wordt een weduwe gebracht naar den broer of neef van haar overleden man en eerst als deze met haar gemeenschap heeft gehad, is zij vrij; wie dit gebod overtreedt, zal sterven. Volgens 3J 93 is na deze daad de jorka van den overledene niet meer een gevaar voor de gemeenschap. Een weduwnaar moet gemeenschap hebben met een vrouw die niet tot den eigen stam behoort. Ook 1H 213 makt melding van deze gebruiken, doch v. L. trekt het in twijfel].

Dagboek d. G. 6 Sept. 1903 te Gransanti aan de Lawa. Gisteravond werd plotseling een geween aangeheven: ,,voor een bloedverwant die 3 maanden geleden gestorven was".

Idem 28 Juni 1904 te Drietabbetje. Dicht bij ons huis dagelijks gehuilebalk van een vrouw die haar man eenigen tijd geleden verloor. Zie voorts $1 \mathrm{G}$ 56-57.

Idem 22 Juni 1937, dorpje van de weduwe van Apinti aan den voet der Apoma-vallen, Marowijne: Tegen 5 uur namiddags gaan al onze Djoeka's met een bankje naar de rivierzijde achter ons huis, gaan zitten en beginnen een klaaggezang; terzijde zit, met den rug naar de mannen, de hoofdvrouw, ook snikkende: er was bericht gekomen, dat een jong familielid te Drietabbetje gestorven was.

Idem 23 Juli 1907 te Sajè aan de Tapanahoni. Reeds dadelijk wordt ons verteld, dat vanavond een groot dansfeest in Sajè plaats zal vinden. Het is n.1. 18 maanden geleden, dat een man stierf. Er wordt nu 3 dagen feestgevierd, waarbij de familie van den overledene alle aanwezigen onthaalt op spijs en drank. Daarbij wordt ook geschoten. $\mathrm{Na}$ afloop wordt de weduwe in de rivier gewasschen door een andere (oude) vrouw, en nu is de kra (geest) van den overledene 
gerustgesteld, en kan de weduwe een ander nemen. Geschiedden deze ceremoniën niet, dan zouden zoowel de vrouw als de nieuwe echtgenoot moeten sterven. Van Simeon hoor ik verder: het ronddragen op een plankje, van verschillende zaken heeft ten doel te spreken met een geest; deze antwoordt dan door middel van teekens. Wil men weten of iemand door toovenarij is gedood, dan vertelt de geest zoo, wie de moordenaar is; vroeger werd deze dan gedood, tegenwoordig geeft men hem een drank in; is hij schuldig, dan sterft hij, anders niet.... we gaan om half negen naar de feestplaats: men is in de huizen aan het eten.... Als we een tijd gezeten hebben, gaan we eens kijken: men zit nu in een open hut, en gedeeltelijk erbuiten, en er worden anansi tori's verteld, en liedjes gezongen. 't Laat zich aanzien, dat de dans eerst laat zal beginnen, en dus ga 'k maar slapen. om half elf. Als 'k echter 's nachts de trommen hoor, ga ik toch nog even kijken. $\mathrm{Er}$ is vrij veel volk aan het dansen: eenige mannen voeren gehurkt de dolste sprongen uit, de vrouwen staan aan den kant, dicht op elkaar, zingen, en draaien lijf en handen; van tijd tot tijd komen ze ook naar voren.

\section{$\S 85$. Jonggestorven kind.}

Sterft een kind binnen het jaar na de geboorte, dan neemt men aan, dat in het kind een takroe jorka (kwade geest) aanwezig was, omdat men meent, dat geen mensch geboren wordt om dadelijk weer te sterven. Of het kind had een goeden geest, doch die is door booze machten van deze aarde weggenomen. Men begraaft daarom het lijkje zonder ceremonieel op een afgelegen plek in het dorp en niet op het kerkhof.

In vroeger jaren echter, werd zoo'n kind binnen een uur na het overlijden onder de lemmetjesdorens begraven: „den beri hem na ondro limikibon" (ze hebben het onder den lemmetjesboom begraven).

Als het graf gedolven was, dan werden naast en in het graf takjes van den lemmetjesboom (Citrus Limetta), die dorens dragen, gelegd. De oudst aanwezige man trad als priester op, die de ceremoniën verrichtte.

Een vrouw bracht het naakte lijkje, in een doek gewikkeld, uit de hut; een man werd haar tegemoet gezonden, die het van haar overnam en het den priester overhandigde. Deze wierp het met een smak in het graf, zeggende: „Je bent nauwelijks op de wereld ge- 
komen, of overhaast verlaat je die weer; dat geschiedt niet zonder reden (,dati a no soso"). Je ziet dan ook wat er met je gebeurd is, je bent teruggestooten (,den toto joe baka"). Het kan ook zijn, dat jijzelf niet de schuldige bent; die jou dan wilde gebruiken, laat die je lichaam (joe doegoedoegoe) nu opeten". Ieder der aanwezigen wierp daarop honend, doch niet zonder het "mi gi heroe" uit te spreken $(\S 82)$, een lemmetjestak in het graf, dat vervolgens met aarde werd opgevuld.

Door de lemmetjestakken werd den kwaden geest de weg om er weer uit te komen versperd. (Vgl. 1P 165 ,Om een wisi te neutraliseeren gebruikt men vooral lemmetjeszuur" en zie $\S 37$ innemen lemmetjeszuur na een steek van een rog). Het gebruik is tegenwoordig vrijwel verdwenen, doch als een geschil beslecht is, of als vijanden zich verzoenen, dan zegt de Djoeka wel: „Na taki koti, tidéi a beri na ondro limmiki", het praten is afgesneden, heden is het onder de lemmetjes begraven.

SAR 1H 222.

\section{§ 86. Albino.}

SAR Als een Tone $(\S 22)$ sterft, dan wordt hij begraven bij den rivieroever. Stn/I/87-88: in diep water geworpen, om ongehinderd te kunnen uitvaren naar de plaats vanwaar hij gekomen is.

\section{$\S 87$. Verdronkene.}

Als iemand verdrinkt, dan meent de Djoeka, dat hier een koenoe, vloek of noodlot, heeft gewerkt. Men belet de jorka van den verdronkene aan wal te komen, door aan den waterkant een afweermiddel op te stellen, bijv. een oude geweerloop, een gebroken houwer, den hopel van een vat, beenderen van dieren, een gebroken kom, lappen salpoers (salempore, een soort doek), enz. Het wordt opgericht door een oudere van het dorp en deze spreekt bijv. „Zij die verdronken zijn behooren in het water thuis en moeten niet terugkomen aan land". $\mathrm{Nu}$ en dan gaat hij die uitspraak vernieuwen. Bij gelegenheden waarbij men voedsel geeft aan de jorka's, wordt het voedsel voor de jorka's der verdronkenen aan den waterkant neergelegd. Niemand komt meer aan dat voedsel, doch de honden kunnen ervan eten.

\section{$\S 88$. Zelfmoord.}

Zelfmoord is niet zeldzaam onder de Djoeka's en andere BoschD1. 99. 
negers. Aanleiding tot zelfmoord is als regel, vrees voor schande, of spijtigheid: een meisje dat zwanger is, drinkt nekoe (vischvergiftliaan) of kassavewater; een oom die zijn nichtje zwanger gemaakt heeft, schiet zich dood; een man die onschuldig veroordeeld is, maakt een einde aan zijn leven; een jonge man die een blauwtje heeft geloopen, of een meisje, dat den man harer keuze vanwege de $l o$ niet mag hebben, maakt een einde aan zijn (haar) leven. Zie ook $\S 66$ een schuldeischer dreigt den schuldenaar, zich van kant te zullen maken. [SAR 1H $74-75$ vermeldt bedreiging met zelfmoord, waarna de jorka wraak zal kunnen nemen; iets dergelijks $3 \mathrm{~J} 135$, 4J 52, 58].

Het lijk van een zelfmoordenaar wordt zonder meer weggeworpen. Het kan zijn, dat bij een zelfmoord Grantata een boete oplegt, die de familie van den zelfmoordenaar dan moet voldoen. Zijn nalatenschap vervalt in elk geval aan Grantata, d.w.z. aan den hoogepriester van Grantata.

\section{§ 89. Haar en nagels.}

Als een Djoeka ver van zijn dorp overlijdt, dan wordt het lijk ter plaatse begraven, nadat men een weinig haar van voor- en achterhoofd, en, bij een man de nagels van rechter middelvinger en linker middelteen, bij een vrouw tegengesteld, heeft afgeknipt. Haar en nagels worden, omdat ze na den dood nog doorgroeien, geacht den overledene te vertegenwoordigen. De familie haalt ze af, om ze op de gebruikelijke wijze in een kleine lijkkist op het kerkhof van de $l o$ te begraven. [Eveneens bij de Saramakkaners, 3J 92, 4J 54, Vandercook 158-159]. De vragen die men anders aan het lijk stelt, worden nu aan haar en nagels gesteld [afbeelding, bij Bonni's $\mathrm{Cr}$ 61]. Ook van iemand die niet in den vreemde is gestorven, bewaart men wel haar en nagels, als men nog vragen heeft te stellen en vaak gaan er jaren voorbij eer men haar en nagels officieel begraaft. In het bijzonder worden hoofdhaar en nagels van afgestorvenen die in hoog aanzien stonden, bewaard; ze worden bij bijzondere godsdienstige plechtigheden gehaald, om degenen van wie ze afkomstig zijn, te vertegenwoordigen; het halen van deze voorwerpen noemt men "go teki bonjo", de beenderen gaan halen (1L 64).

§ 90. Afschuw lijkverbranding (d. G.).

Zoowel Djoeka's als Bonni's betuigden mij hun afschuw van het 
gebruik der Oajana-Indianen om het lijk van een gestorven mensch te verbranden; zij hebben getracht de Oajana's af te brengen van deze gewoonte, doch hadden daarbij hoogstens tijdelijk succes.

$\S 91$. Dood en rouwgebruiken bij andere Boschnegers en bij Stadsnegers.

De ceremoniën vertoonen veel overeenkomst met die der Djoeka's. BONNI Zie Cr 59-61 met plaat, Ve 322-323, 1F 143-144.

SAR Zie $1 \mathrm{H} 3$ vlg., 5J en 3J, Sta 566-567; Stn I/2/276 vlg. ver. meldt, hoe men de jorka nadrukkelijk verzoekt om niet terug te keeren; $1 \mathrm{~J}$ 452-453 vermeldt, hoe het lijk van iemand die door een ongeluk om het leven is gekomen, ter plaatse wordt begraven en met bepaalde middelen behandeld wordt, om de wraakzuchtige jorka aan die plaats te binden.

STAD Zie 2H 109-110, 137 vlg., Bex VII, MK. De feesten voor den doode hebben ook hier ten doel de jorka te bevredigen; men duidt ze aan met dedde hoso (dood huis) en poeloe na pikien na passi (het kind verwijderen); de laatste plechtigheid heet fissa of fesa (feest). Zie ook $\S 8$.

\section{AANVULLINGEN.}

Uit Suriname; kwamen nog inlichtingen van den heer van Lier en van de heeren M. A. L. Melcherts en W. Rogalli. Hier volgen ze, gerangschikt naar de $\S \S$ waarbij ze thuis behooren.

$\S 52$. Bij groote onheilen, zooals epidemiën (griep 1918, 1922). abnormale droogte (1926) enz., worden er algemeene bededagen voor den geheelen stam gelast, te Drietabbetje te houden (W. L. Loth 88 , was getuige van iets dergelijks). De bedediensten worden door den Granman ingeleid en door de hoogepriesters voortgezet en duren dagen en soms weken. Er wordt geofferd aan de Granjorka's en gesmeekt "foe kroetoe gi dem na Gado-kondre", om voor hen (den stam) te pleiten in het Godsrijk. Grantata wordt daarbij geregeld geraadpleegd en men smeekt hem, de middelen aan te geven, waarmede de harten der goden verteederd kunnen worden, opdat de toestand een gunstige wending neme. Betreft het herhaalde misluk- 
king van den oogst of van de ponsoe's ( $\S 80)$, of vertoonen de pingo's (wilde zwijnen) zich nog maar zelden, dan worden deze gebedsdiensten gehouden op Kriorokondre, de offerplaats voor Gedeosoe, den god van den landbouw, de vischvangst en de jacht. De Granman reist daarheen om de plechtigheden te openen, vertoeft er enkele dagen en keert dan terug naar Drietabbetje, met achterlating van hoogepriesters die hem vervangen en die, tezamen met de bilo-priesters en priesters van Gedeosoe, de diensten voortzetten.

- Omtrent Akrekoena valt nog te melden: deze gado openbaarde zich het eerst bij een man der Pinassi-lo aan de Sara-kreek, aanvankelijk in den droom, daarna als bezetenheid. Oséisi gaf last den gado over te brengen naar de Tapanahoni en hij werd daar gevestigd bij de opo-negers van het dorpje Akrekoena (boven Godohoro), een nederzetting der Pinassi-negers van het dorp Kisai; nadat Akrekoena verlaten was, ging de gado naar Kisai.

$\S 54$. De Afrakoe moet zijn goedgekeurd en gewijd door den Opperpriester van Grantata.

- Asigoe (2K) zou volgens een Saramakkaner, de godheid zijn, die huist in een Ceyba-boom welken men opzettelijk voor aanbiddingsdoeleinden heeft geplant.

- Aflamoe (de Leeuw 74, 124) is niet een eigenlijke godheid. Een Djoeka van de Cottica, Wensi genaamd (Melcherts kent hem persoonlijk) kreeg (hetzij spontaan, hetzij doordien Christelijke leeringen indruk op hem hadden gemaakt, vgl. de droomen van Johannes King, Burkhardt 47-48; d. G.) een verschijning van een in 't wit gekleeden jongeling, wiens aangezicht blonk als de zon, en die voorafgegaan werd door een duif; de verschijning, die later nog eens terugkwam, noemde zich Amafoe of Aflemoe en droeg hem op, naar de Tapanahoni te gaan en daar de afgoderij uit te roeien.

- De kokoti is een attribuut van de Kromanti-gado's, of van andere gado's; het ligt eraan in welke obia-hoso deze stok zich bevindt. Hij wordt door den begeesterden bij wijze van staf gedragen, en alsdan noemt de gado dien staf ,,kokoti bai bati foe santi a kwa".

$\S 55$. Volgens Melcherts noemt men den hoofd-fragatiki kortweg fa-aka (vlag). Te Drietabbetje en te Poeketi is er een kroetoehoso of granwanhoso waar de groote kroetoe's onder leiding van Granman of Opperpriester gehouden worden. Op de andere dorpen houdt men 
kroetoe in het gastenhuis van den kapitein, of, bij goed weder, onder een grooten boom. De kréihoso wordt alleen gebruikt om er lijken in te plaatsen.

§ 57. Bestanddeelen van obia's: hert, daar het hert bijzonder vlug is en uithoudingsvermogen heeft; konijn (agoeti), daar dit slim en voorzichtig is en overleg bezit. Het roode haar van het achterdeel van een konijn behoort zoowel in de jacht- als in de sexueele manningre-obia, De Boschnegers beweren dat het konijn ,sabi loekoe obia" (weet zien obia), waarmede bedoeld is, dat het instaat is zijn eigen orakel te raadplegen. Het konijn heeft n.l. de gewoonte om op zijn achterpooten rechtop te zitten, zooals hondjes dat kunnen doen. In die houding brengt het dan de voorpooten bij elkaar tegen zijn lippen en het lijkt den toeschouwer die het op een afstand waarneemt, alsof het dier tegen die voorpooten wind aanblaast of ertegen spuwt en ze vervolgens aan zijn neus brengt. Als een konijn daarmede bezig is, mag men er nooit op schieten.

$\S 59$. Den ijzeren ring voor den bovenarm (manfeti obia) noemt men njankoe boei; men kan den ring, alvorens men hem aan den arm steekt, aan een touwtje hangen, met alcohol besprenkelen en ondervragen of men in het komend gevecht zal overwinnen.

$\S 75$. Als opsmuk draagt men ook wel om den hals een anjisa (hoofddoek).

$\S$ 13. De obiaman's hebben een of meer kina's van hun obia. Voorts mag in de tegenwoordigheid van iemand die met een gado verbonden is ( $\$ 36)$ de naam van dien gado niet genoemd worden, in het bijzonder niet, wanneer de betrokkene aan het eten is. Gebeurt dat, dan ziet men hem als geëlectriseerd opspringen, zijn mond leegspuwen, het eten dat hij nog op zijn bord had, weggooien en zich met haast verwijderen. Ik heb het meermalen bijgewoond, dat zoo iemand aan het braken geraakte, en ziek werd.

$\S 26$. Voor de Njafaai-negers is het eten van den kwatta-aap kina. Want eens waren van een dorp de mannen afwezig en een troep Bonni-negers wilde daarvan gebruik maken om de vrouwen en meisjes te rooven. Doch net toen zij naderden, kwam er een troep kwatta-apen, die zoo'n rumoer maakten, dat de roovers meenden, dat de Njafaai-mannen aankwamen, en ijlings de vlucht namen.

$\S 46$. Enkele jaren geleden is een Djoeka-neger bij ongeluk door een soldaat met een geweerschot verwond en kwamen ambtenaren 
om de zaak te onderzoeken. Het zou echter overtreding van de kina der genezing zijn, om hen bij den gewonde toe te laten; de genezing zou daardoor belemmerd worden, of de gewonde zou er zelfs door kunnen sterven. Men vond er toen dit op, dat een obiaman met een kalebas met een mengsel van kruiden en pimba zich opstelde bij den ingang der hut waarin de gewonde lag. De blanken moesten een voor een op een matje gaan staan, waarbij de obiaman hen onder het opzeggen van gebeden de voeten met het mengsel besprenkelde. Daardoor werd al wat de kina zou kunnen bederven, geneutraliseerd. 